UNIVERSIDADE DE SÃO PAULO

Faculdade de Arquitetura e Urbanismo

ANNE KETHERINE ZANETTI MATARAZZO

Composições cromáticas no ambiente hospitalar: estudo de novas abordagens 


\section{Composições cromáticas no ambiente hospitalar: estudo de novas abordagens}

Dissertação apresentada à Faculdade de Arquitetura e Urbanismo da Universidade de São Paulo para obtenção do Título de Mestre em Arquitetura e Urbanismo.

Área de Concentração: Tecnologia da Arquitetura

Orientador: Prof. Dr. João Carlos de Oliveira César 
AUTORIZO A REPRODUÇÃO E DIVULGAÇÃO TOTAL OU PARCIAL DESTE TRABALHO, POR QUALQUER MEIO CONVENCIONAL OU ELETRÔNICO, PARA FINS DE ESTUDO E PESQUISA, DESDE QUE CITADA A FONTE.

E-MAIL: arqmatarazzo@yahoo.com.br

Matarazzo, Anne Ketherine Zanetti

M425c Composições cromáticas no ambiente hospitalar : estudo de novas abordagens / Anne Ketherine Zanetti Matarazzo -São Paulo, 2010.

215 p. :il

Dissertação (Mestrado - Área de Concentração:

Tecnologia da Arquitetura) - FAUUSP.

Orientador: João Carlos de Oliveira César

1. Cor na arquitetura 2. Edifícios hospitalares

3. Percepção de cor 4. Percepção visual 5. Saúde

I .Título

CDU 72:7.017.4 
MATARAZZO, A.K.Z. Composições Cromáticas no Ambiente Hospitalar: Estudo de Novas Abordagens. Dissertação apresentada à Faculdade de Arquitetura e Urbanismo da Universidade de São Paulo, para obtenção do Título de Mestre em Arquitetura e Urbanismo.

Área de Concentração: Tecnologia da Arquitetura.

Aprovado em

\section{Banca Examinadora}

Prof. Dr. João Carlos de Oliveira César - Orientador Instituição: FAUUSP

Departamento: Tecnologia da Arquitetura

Prof. Dr.

Instituição:

Departamento:

Assinatura

Prof. Dr.

Instituição:

Departamento:

Assinatura de de 2010 . 
Às estrelas guias, Rita e Isabella 


\section{Agradecimentos}

A Deus, que é parte essencial de minha caminhada, pela beleza das cores.

À minha mãe, pelo exemplo de perseverança, nunca me deixando desistir e me incentivando à realização de meus sonhos, e por todos os dias e noites que cuidou carinhosamente de minha filha para a realização deste.

Ao meu marido, Fábio, pela paciência, amor no olhar companheiro e ajuda sem limites.

À minha filha, Isabella, que me mostrou um mundo mais colorido e a possibilidade do amor infinito.

Ao meu orientador, Prof. Dr. João Carlos, que sempre se mostrou solidário, atencioso e comprometido com este trabalho.

Aos meus irmãos, Hellen e Ulysses, pelo amor, pelos comentários pertinentes e pela ajuda sempre dispensada.

A minha tia-mãe, Maria Aparecida, pelos incentivos e ajudas infinitas e pelo amor em forma de orações.

A minhas amigas, irmãs, Aniella e Kathia, por todo o apoio, atenção e incentivo em todo o caminho deste trabalho e pela amizade valiosa.

Aos grandes mestres que tive na vida escolar, Prof ${ }^{a}$. Ediane, Prof. Marins, Prof ${ }^{\mathrm{a}}$. Adriana, Prof. Montenegro e a tantos outros que, com dedicação e amor ao ensino, me motivaram a seguir a jornada acadêmica.

Aos arquitetos Ricardo e Cibele, pelos ensinamentos e pela confiança que sempre depositaram em mim.

À todos esses, minha eterna gratidão, pelo incansável apoio e incentivo. 
"Estou inclinada a pensar que a maioria dos casos alegres se encontra entre aqueles que não estão confinados a um quarto, o quer que eles sofram, e que a maioria dos casos deprimidos será visto entre aqueles submetidos a uma longa monotonia de objetos ao seu redor. A estrutura nervosa realmente sofre tanto com isso como os órgãos digestivos sofrem com uma dieta monótona. O efeito sobre a doença de objetos bonitos, da variedade de objetos e, especialmente, do brilho das cores, dificilmente é apreciado. Tais desejos são geralmente chamados de "caprichos" dos pacientes, mas esses "caprichos" são as indicações mais valiosas do que é necessário para a sua recuperação. As pessoas dizem que o efeito é apenas na mente. Não é nada disso. O efeito é sobre o corpo também. Pouco como sabemos sobre a maneira pela qual somos afetados pelas formas, cor e luz; sabemos isto: que eles têm um efeito real e físico. A variedade de formas e o brilho das cores nos objetos apresentados aos pacientes são um meio efetivo de recuperação". 
MATARAZZO, A.K.Z. Composições Cromáticas no Ambiente Hospitalar: Estudo de Novas Abordagens. 2010. 215p. Dissertação (Mestrado) - Faculdade de Arquitetura e Urbanismo, Universidade de São Paulo, São Paulo, 2010.

Este trabalho objetiva analisar as composições cromáticas aplicadas, no ambiente hospitalar, buscando uma correlação entre as cores usadas, nas composições e no bem-estar físico, psicológico, emocional e social de pacientes hospitalares, tendo em vista possíveis influências ao tratamento terapêutico de cura. Partiu-se do princípio que o ambiente construído influencia ações, sentimentos e emoções humanas. A cor, sendo um dos principais elementos da arquitetura, participa ativamente às respostas humanas decorrentes de sua interação com o ambiente. $O$ estudo compreendeu as questões relativas às cores em todos os seus aspectos e as inúmeras possibilidades de suas aplicações na arquitetura. Focou-se o estudo, no ambiente hospitalar, que vem passando por reformulações, guiadas por pesquisas, nas áreas da psicologia ambiental, neurociência e psicofísica. Levantando-se as recentes conceituações e diretrizes projetuais para o design do ambiente hospitalar, foi possível verificar a ocorrência das composições cromáticas como elementos transformadores. Por fim, para demonstrar as relações que se estabeleceram entre as composições cromáticas, o design do ambiente hospitalar e a promoção à saúde, constituindo projetos denominados de "Hospitais do Futuro", foram apresentados três casos, cujos projetos ilustram representativamente as questões debatidas neste trabalho. Ao se realçar o papel das composições cromáticas e do design hospitalar, no processo de recuperação da saúde e no bem-estar dos usuários, evidenciou-se o papel do arquiteto como agente central, possibilitando e criando condições ideais para o tratamento terapêutico e para o desenvolvimento das atividades. Foi identificado, como resultado da pesquisa, que o design, capaz dessas transformações, deve, acima de tudo, considerar a variedade de estímulos, e voltando-se às composições cromáticas, representa as variedades de matizes, a contraposição de brilho das superfícies e o uso de contrastes.

Palavras-chave: Cor na arquitetura. Edifícios hospitalares. Percepção de cor. Percepção visual. Saúde. 
MATARAZZO, A.K.Z. Chromatic Compositions in the Hospital Environment: Study of New Approaches. 2010. 215p. Thesis (MA) - Faculdade de Arquitetura e Urbanismo, Universidade de São Paulo, São Paulo, 2010.

This paper aims to analyze the chromatic compositions applied in the hospital environment, looking for a correlation between the colors used in the compositions and the physical, psychological, emotional and social well-being of the hospital patients, with a view to its possible influence in therapeutic healing. It started from the assumption that the built environment influences in actions, feelings and human emotions. The color, one of the main elements of architecture, participates actively in the responses resulting from human interaction with the environment. The study included questions relating to color in all its aspects and the many possibilities of its applications in architecture. It was also focused in the hospital environment, subject that has been under reformulations guided by researches in the fields of environmental psychology, neuroscience and psychophysics. Raising the recent conceptualizations and projective guidelines for the hospital environment design, it was possible to detect the chromatic compositions as elements capable to transform. Finally, to demonstrate the relationships established between the chromatic compositions, the design of hospitals environment and health promotion, composing projects named as "Hospitals of the Future", three cases were presented, whose projects representatively illustrate the issues discussed in this paper. By highlighting the function of chromatic compositions of the hospital environment design in the process of regaining the user's health and well-being, the role of the architect as a central agent was demonstrated, enabling and creating ideal conditions for the therapeutic treatment and for the activities development. As a result of the research, it was identified that the design capable of these transformations must above all consider the variety of stimuli, and turning to the chromatic compositions, it represents the variety of hues, the contraposition of the surface brightness and the use of contrasts.

Keywords: Color in Architecture. Hospital buildings. Humanization. Color Perception. Visual Perception. Health Care. 


\section{Lista de Figuras}

\section{Capítulo 2}

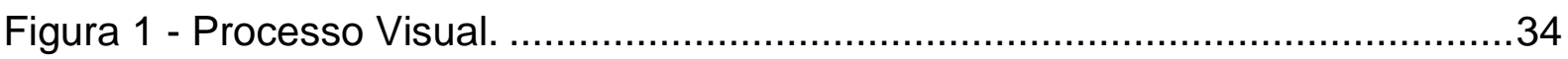

Figura 2 - Representação dos raios de luz em uma superfície. ..............................36

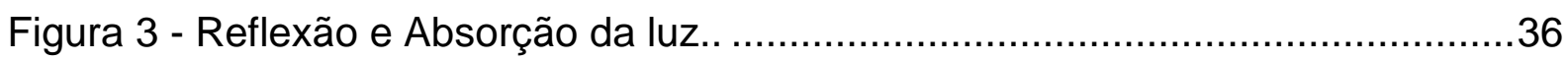

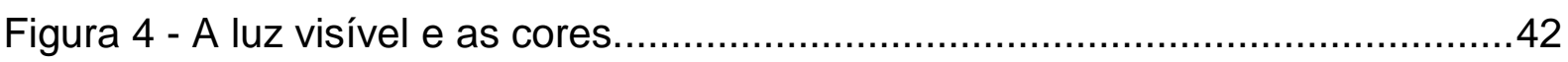

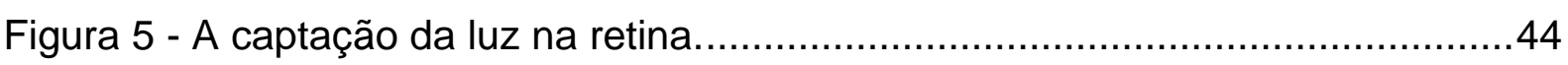

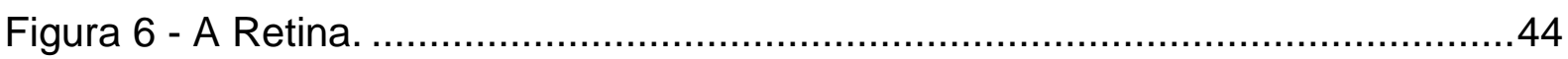

\section{Capítulo 3}

Figura 7 - Representação da experiência de Newton. ..........................................48

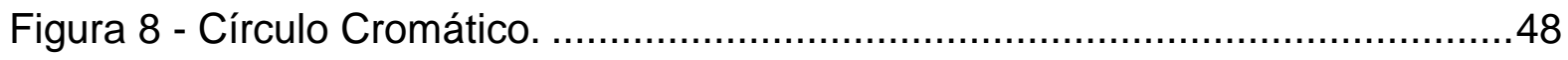

Figura 9 - Sensibilidade dos cones do olho humano.........................................50

Figura 10 - Representação da Teoria de Hering .............................................50

Figura 11 - Rosa dos Temperamentos. Círculo cromático de Goethe. .....................53

Figura 12 - llustração dos dois sistemas de mistura das cores -

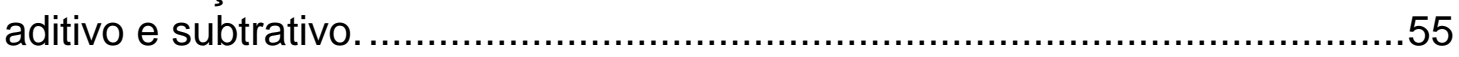

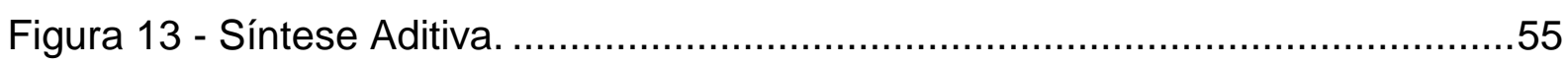

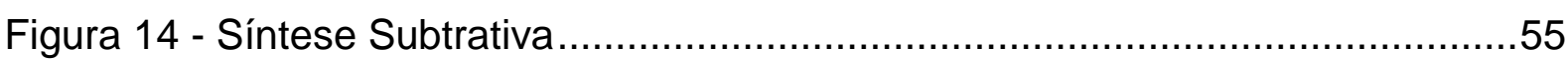

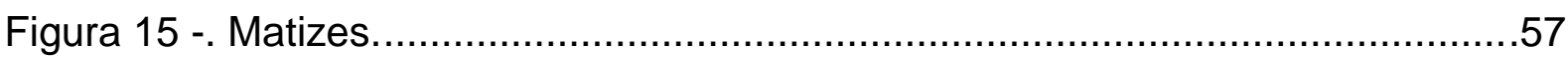

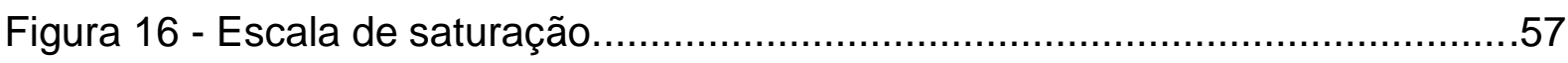

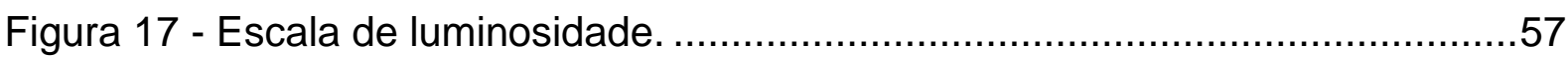

Figura 18 - Relações dos atributos no Sistema Ostwald......................................60

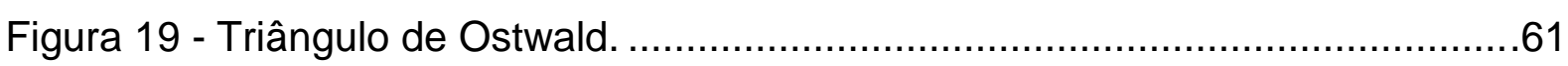

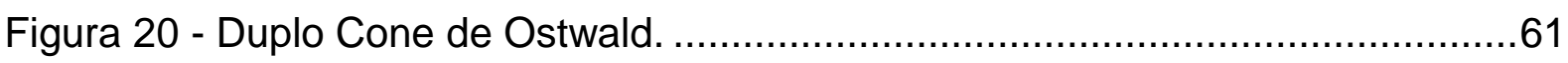

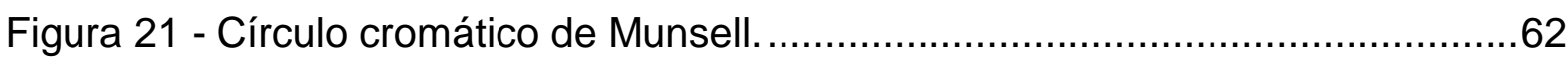

Figura 22 - Esquema dos eixos do sistema Munsell. ..........................................62

Figura 23 - A escala de luminosidade e saturação de um matiz..............................63

Figura 24 - Sólido das cores de Munsell. .........................................................63

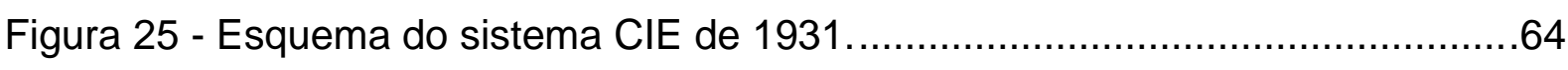

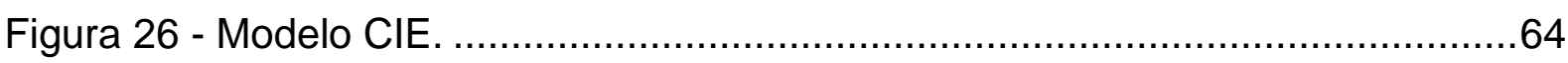

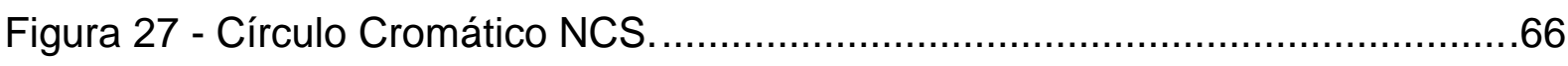

Figura 28 - Detalhe de uma notação NCS ......................................................66

Figura 29 - Um matiz no Espaço de Cores NCS................................................66 
Figura 30 - Notação NCS de um matiz.

.67

\section{Capítulo 4}

Figura 31 - Aspectos envolvidos na percepção cromática. 76

\section{Capítulo 5}

Figura 32 - Fatores de influência na percepção das cores.................................98

Figura 33 - Cisco LifeConnections Health Center, California. .................................101

Figura 34 - Children's Hospital of Pittsburgh of UPMC...................................... 101

Figura 35 - Children's Hospital of Pittsburgh of UPMC ..................................... 102

Figura 36 - American British Cowdray Women's and .......................................... 103

Figura 37 - King's Mill Acute Care Hospital PFI, Reino Unido.................................103

Figura 38 - Montefiori Medical Center. .............................................................. 104

Figura 39 - Montefiori Medical Center. .......................................................... 107

Figura 40 - Birmingham Children's Hospital. ..................................................107

Figura 41 - Hospital Paulistano, São Paulo..................................................108

Figura 42 - California-Pacific-Medical-Center.............................................. 108

Figura 43 - Children's Hospital of Pittsburgh of UPMC....................................112

Figura 44 - Corredores Emergência, Hospital Paulistano, São Paulo.....................113

\section{Capítulo 6}

Figura 45 - Gravura da sala dos pacientes no templo de Asclépio. .......................118

Figura 46 - Valetudinárias dos romanos.....................................................118

Figura 47 - Leprosário St Mary Magdale, Cambridge.........................................119

Figura 48 - St. Mary's Hospital, Dover, séc. XIII...........................................120

Figura 49 - Gravura de assistência aos doentes, Paris. ...................................120

Figura 50 - St. MarysHospital. Sec XIII - Londres.........................................120

Figura 51 - Representação de hospital medieval, .......................................... 121

Figura 52 - Acima: Enfermaria e detalhe do teto. Ao lado: planta baixa,

St Giles' hospital, Reino Unido, séc. XIII - XVI.......................................121

Figura 53 - Gravura Hotel Dieu, Paris, séc. XIX............................................ 123

Figura 54 - St. Bartholomew's Hospital, Londres, séc. XVIII. ...............................123

Figura 55 - Modelo de enfermaria Nightingale ............................................... 120

Figura 56 - Hospital Hotel Dieu, Montreal, início séc. XX...................................124

Figura 57 - John's Hopkins Hospital. Enfermaria em 1900 e vista externa. ............125 
Figura 58 - Hospital Beaujon, Clichy/ França - 1929.......................................127

Figura 59 - Hospital Santa Cruz da Misericórdia de Santos.................................129

Figura 60 - Conjunto arquitetônico Histórico de Manguinhos,

Fundação Oswaldo Cruz, início do séc. XX.....

Figura 61 - Hospital das Clínicas da Faculdade de Medicina da Universidade de São Paulo, séc. XX.

Figura 62 - Projetos da Rede de Hospitais SARAH.

\section{Capítulo 7}

Figura 63 - Herlev Hospital, Dinamarca. 149

Figura 64 - Herlev Hospital, Dinamarca. 149

Figura 65 - Sala de Centro Cirúrgico. Providence Newberg Medical Center. 153

Figura 66 - Posto de enfermagem. - Evergreen Medical Center. 155

Figura 67 - Sala de recuperação - Evergreen Medical Center. 155

Figura 68 - Harmonia por analogia. 158

Figura 69 - Harmonia por cores opostas. 158

Figura 70 - Harmonia por tríade. 159

Figura 71 - Escala Monocromática. 159

Figura 72 - Corredor da ala de internação - FUST. 162

Figura 73 - Espera - Emergência. Hospital Paulistano, São Paulo. 162

Figura 74 - Lobby - Bristol Royal Hospital of Children, Reino Unido. 164

Figura 75 - PSE\&G Children's Specialized Hospital, Nova York. 164

Figura 76 - Contraste de brilho. 167

Figura 77 - Representação do Contraste Simultâneo.

Figura 78 - Representação do Contraste Sucessivo.

Figura 79 - Hospital Paulistano, São Paulo.

Figura 80 - Children's Hospital of Pittsburgh of UPMC. 169

Figura 81 - PSE\&G Children's Specialized Hospital, Nova York. 171

Figura 82 - Hospital de Santo André, Portugal.

Figura 83 - PSE\& G Children's Specialized Hospital, Nova York..........................172

Figura 84 - Bristol Royal Hospital of Children, Reino Unido. .................................172

Figura 85 - Hospital Regional do Vale do Paraíba. ............................................176

Figura 86 - Children's Hospital of Pittsburgh of UPMC......................................177

Figura 87 - Boulder Community Hospital, Colorado. ..........................................178

Figura 88 - Herlev Hospital, Dinamarca. ...................................................118

Figura 89 - Elementos artísticos. Athos Bulcão................................................180 
Figura 90 - Providence Newberg Medical Center.

\section{Capítulo 8}

Figura 91 - Desenhos esquemáticos do átrio principal -

Royal Hospital for Sick Children.

Figura 92 - À esquerda: Perspectiva do átrio. À direita: Perspectiva da fachada principal - Royal Hospital for Sick Children.

Figura 93 - Perspectivas das áreas internas -

Karolinska Solna University Hospital.

Figura 94 - Perspectiva da fachada principal -

Karolinska Solna University Hospital.

Figura 95 - Mural - Children's Hospital of Pittsburgh

Figura 96 - À esquerda: Enfermaria. À direita: Jardim externo -

Children's Hospital of Pittsburgh.

Figura 97 - Átrio principal - Children's Hospital of Pittsburgh

\section{Lista de Tabelas}

Tabela 1 - Graus de reflexão das superfícies ideais para o conforto visual 108

Tabela 2 - Graus de reflexão em percentual do fluxo luminoso incidente. 109 


\section{Lista de Abreviações e Siglas}

ABDEH - Associação Brasileira para o Desenvolvimento do Edifício Hospitalar ABNT - Associação Brasileira de Normas Técnicas

AIC - International Colour Association

ANVISA - Agência Nacional de Vigilância Sanitária

ASHE - American Society of Healthcare Engineering of the American Hospital Association

CIE - Commission Internacionale de l'Eclairage

DIN - Deustsches Institut fur Normung

EAS - Estabelecimentos Assistenciais de Saúde

EBD - Evidence-Based Design

FUST - Fundação Universitária de Saúde de Taubtaé

GAC - Grupo Argentino del Color

GGHC - Green Guide for HealthCare

IADH - International Academy for Design and Health

IASDR - International Association of Societies of Design Research

LEED - Leadership in Energy and Environmental Design

NCS - Natural Color System

NUTAU - Núcleo de Pesquisa em Tecnologia da Arquitetura e Urbanismo

$\mathrm{PFI}$ - Private Finance Initiative

PNHAH - Programa Nacional de Humanização da Assistência Hospitalar

PSE\&G - Public Service Electric and Gas Company

SCC - Sistema de Cores Cecor

UPMC - University of Pittsburgh Medical Center

USGBC - United States Green Building Council

USP - Universidade de São Paulo 
CAPÍTULO 1: INTRODUÇÃO..................................................................... 17

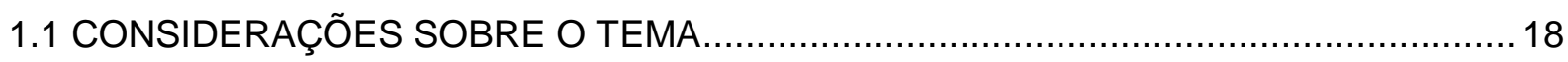

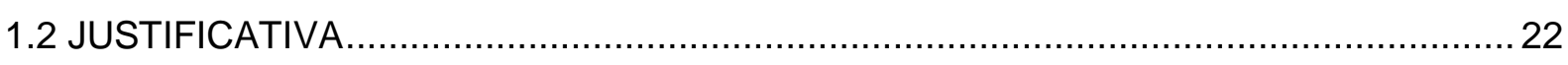

1.3 OBJETO DE ESTUDO

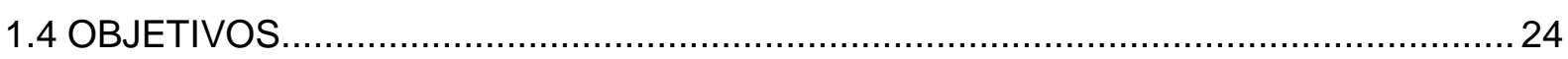

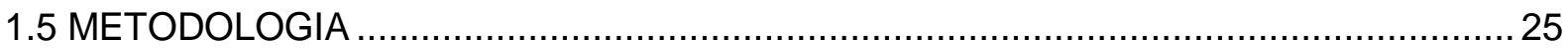

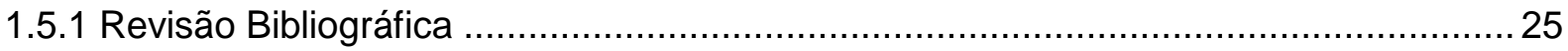

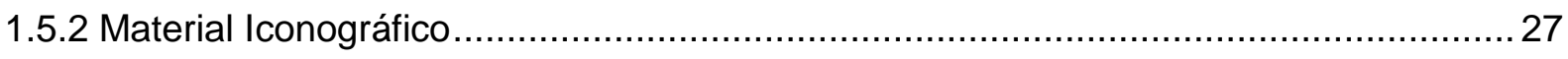

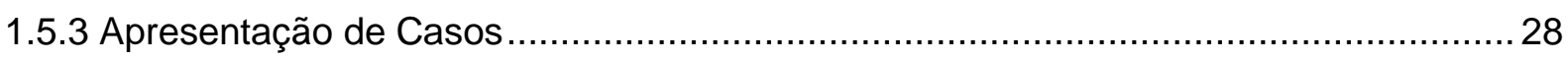

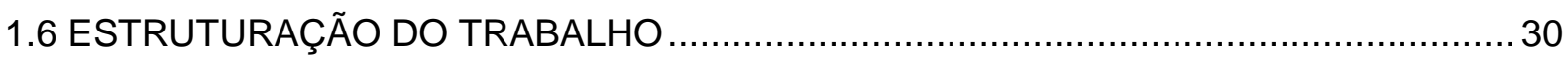

CAPÍTULO 2: FORMAÇÃO DAS CORES: VISÃO E PERCEPÇÃO.................. 32

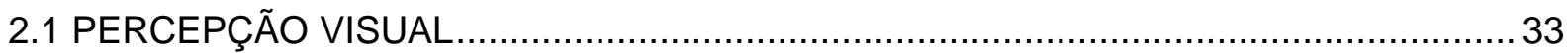

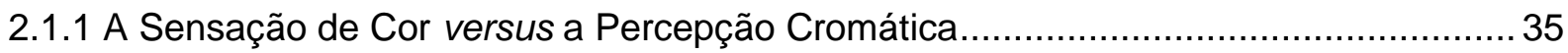

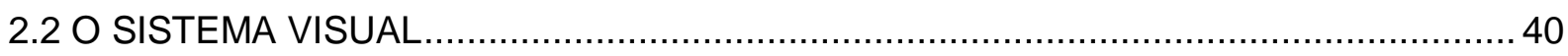

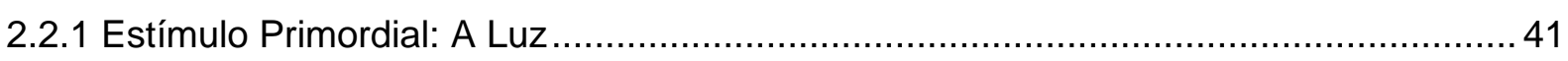

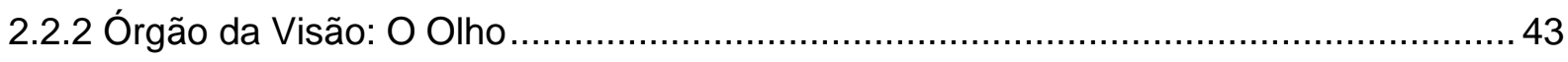

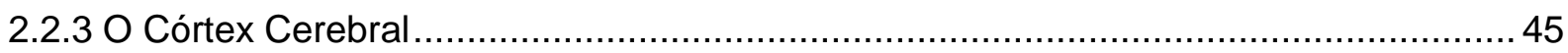

CAPÍTULO 3: PRINCÍPIOS PARA O ESTUDO DAS CORES........................... 48

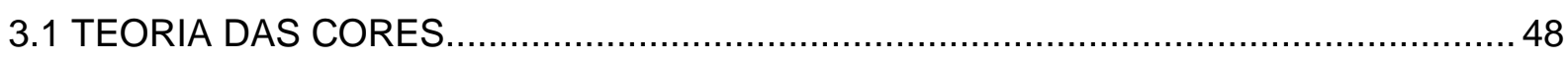

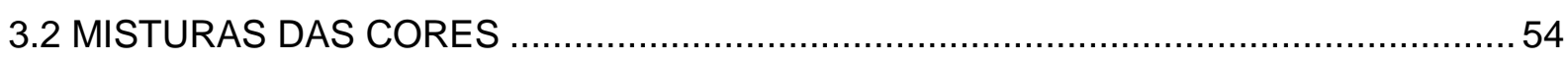

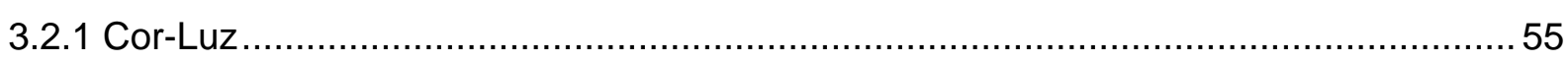

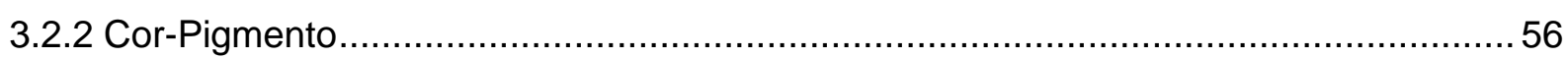

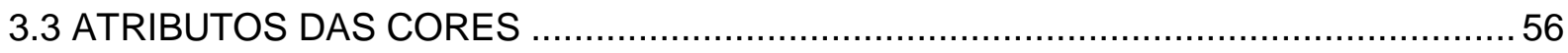

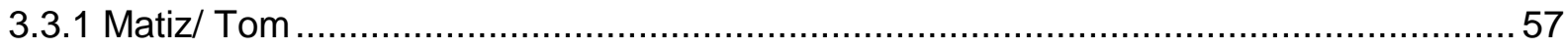

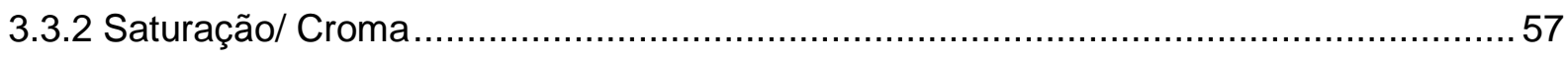

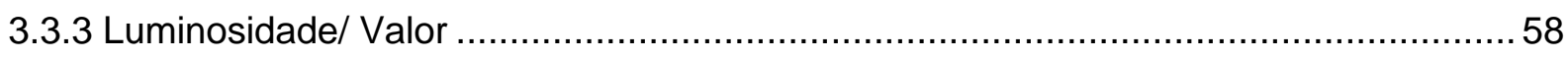

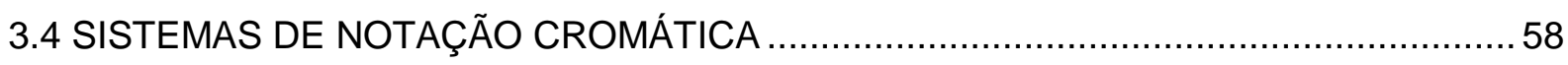

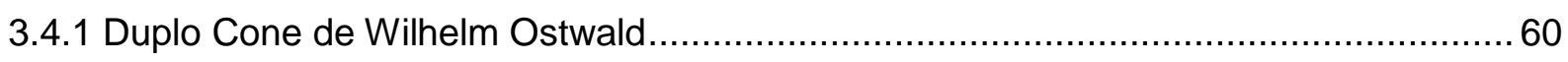

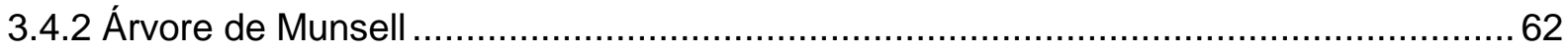

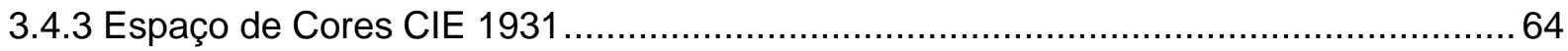


3.4.4 Sistema Natural das Cores NCS 65

3.4.5 SCC: Um Sistema de Notação Cromática Brasileiro .................................................. 67

3.4.6 Outros Sistemas de Notação Cromática ........................................................... 68

CAPÍTULO 4: ASPECTOS COGNITIVOS DAS CORES .................................70

4.1 ASSOCIAÇÕES E SIMBOLISMOS DAS CORES: INFLUÊNCIAS PARA O DESIGN....71

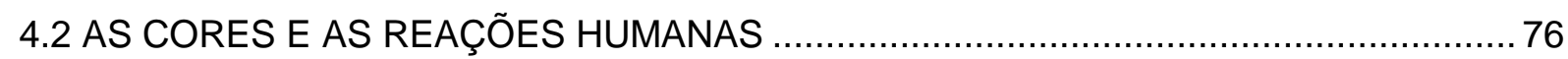

4.2.1 Efeitos Objetivos, Subjetivos e Psicofísicos da Cor no Ser Humano ........................... 76

4.2.2 Reações Fisiológicas e Biológicas ..................................................................... 78

4.2.3 Reações Psicológicas e Comportamentais ........................................................... 80

4.3 EMOTIONAL COLOR: UMA ABORDAGEM ATUAL PARA COMPOSIÇÕES

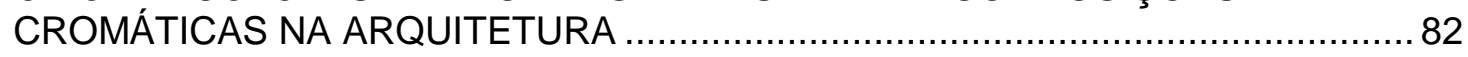

CAPÍTULO 5: O USO DAS CORES NA ARQUITETURA: QUESTÕES PERCEPTIVAS E APLICAÇÕES PRÁTICAS...... 86

5.1 BREVE HISTÓRICO: ARQUITETOS, ARQUITETURAS E AS CORES ......................... 87

5.2 CONSIDERAÇÕES ACERCA DA COR NA ARQUITETURA ..................................... 91

5.2.1 Percepção Ambiental: Introdução à Percepção Espacial ........................................... 91

5.2.2 As Influências das Cores na Percepção das Formas .............................................. 95

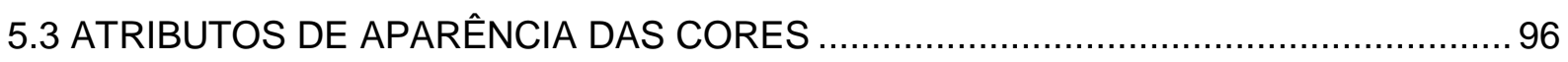

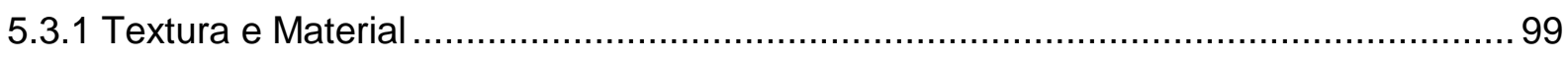

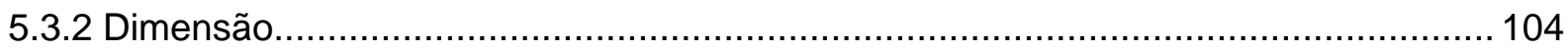

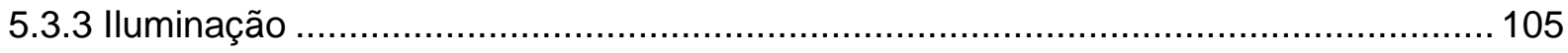

5.3.3.1 Iluminância e Luminância...................................................................... 110

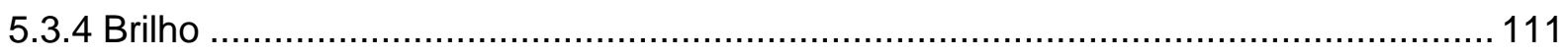

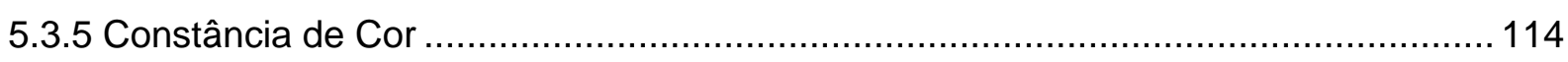

CAPÍTULO 6: A ARQUITETURA HOSPITALAR..........................................116

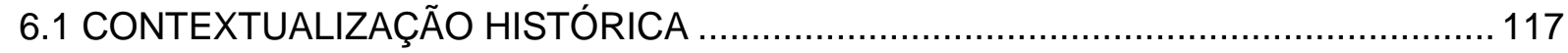

6.1.1 Entendendo o Hospital Contemporâneo: Os Primórdios do Edifício Hospitalar ......... 117

6.1.2 Os Caminhos da Arquitetura Hospitalar Brasileira: A Partir das Santas Casas de

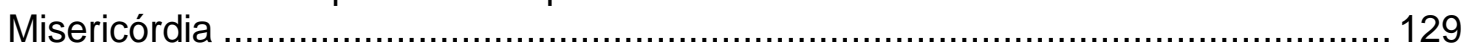

6.1.2.1 A Normatização como Instrumento de Desenvolvimento do Edifício Hospitalar ..... 133

6.2 UMA VISÃO SOBRE A HUMANIZAÇÃO HOSPITALAR ......................................... 136

6.2.1 A Humanização do Ambiente Hospitalar Focada no Paciente: A Arquitetura como Agente de Cura. 


\section{CAPÍTULO 7: APLICABILIDADE DAS CORES NO} AMBIENTE HOSPITALAR 147

7.1 POSSIBILIDADES DO USO DAS CORES NO AMBIENTE HOSPITALAR 147

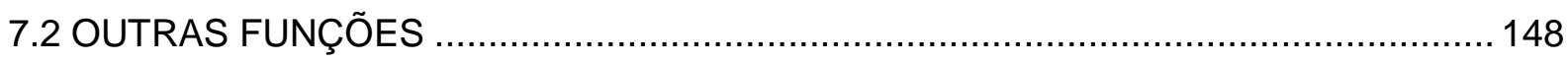

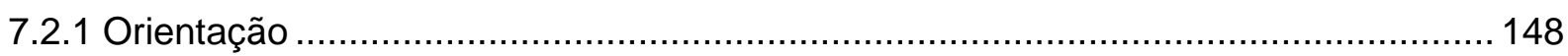

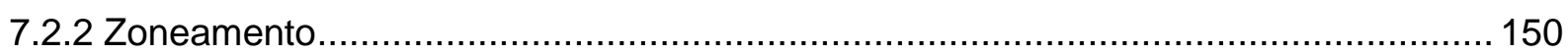

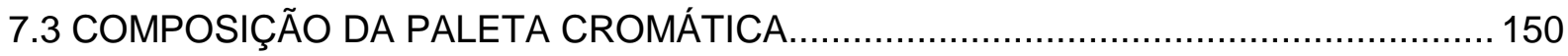

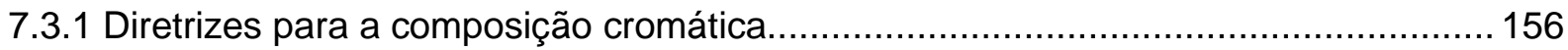

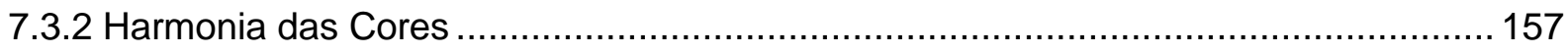

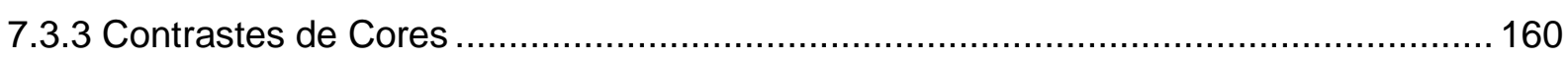

7.3.3.1 Contraste Sucessivo e Simultâneo................................................................ 166

7.3.4 Características das Cores: Indicações para a Composição da Paleta Cromática...... 168

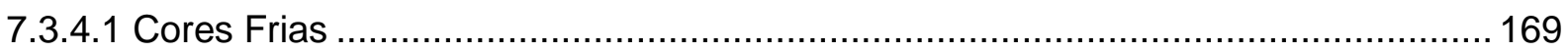

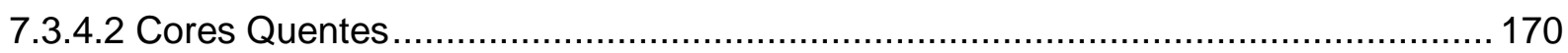

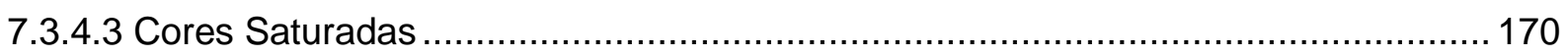

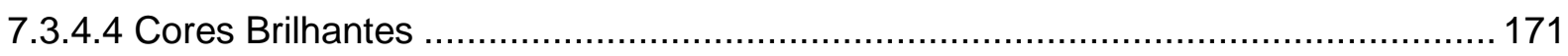

7.4 APLICAÇÃO DA PALETA CROMÁTICA NO DESIGN HOSPITALAR........................ 174

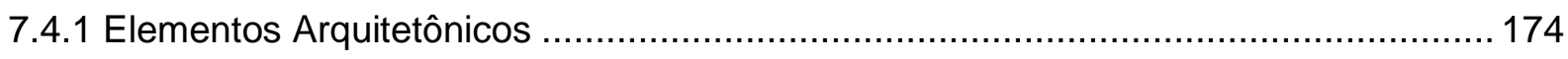

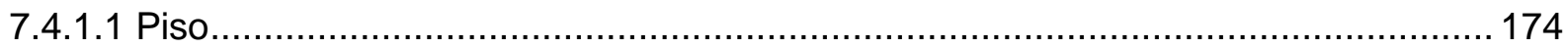

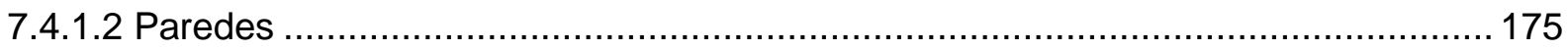

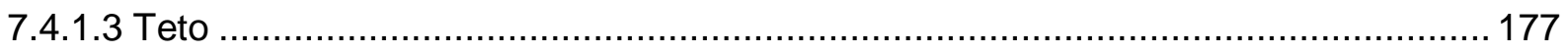

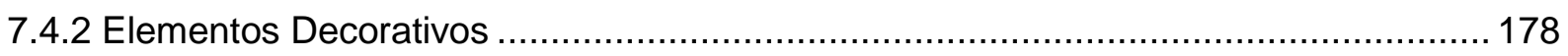

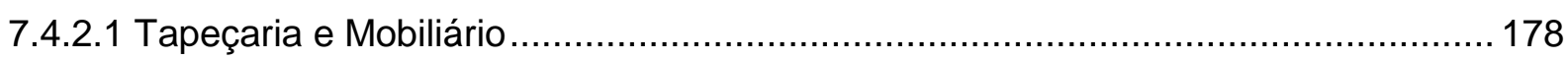

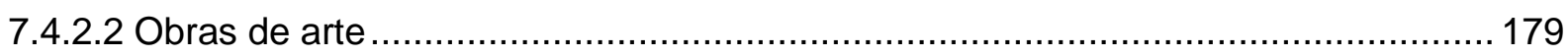

\section{CAPÍTULO 8: O "HOSPITAL DO FUTURO":}

BASES NAS COMPOSIÇÕES CROMÁTICAS.......................182

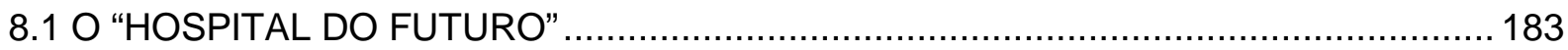

8.2 EXPLOSÃO DE CORES PARA AS NOVAS DIRETRIZES PROJETUAIS .................... 185

8.3 COMPOSIÇÕES CROMÁTICAS NO "HOSPITAL DO FUTURO": 3 CASOS ................ 186

8.3.1 Royal Hospital For Sick Children...................................................................... 187

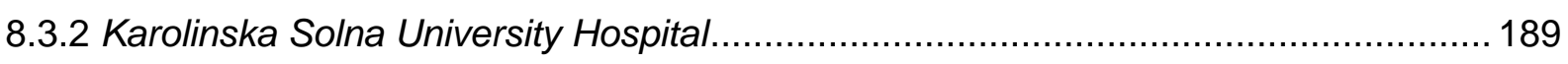

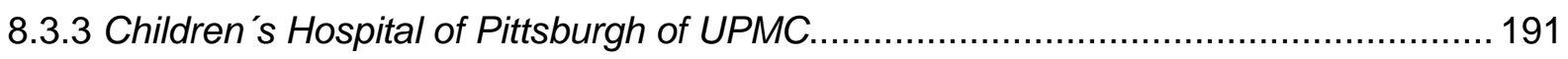


CAPÍTULO 9: CONSIDERAÇÕES FINAIS................................................... 196

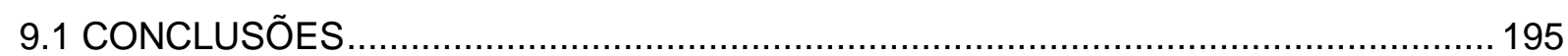

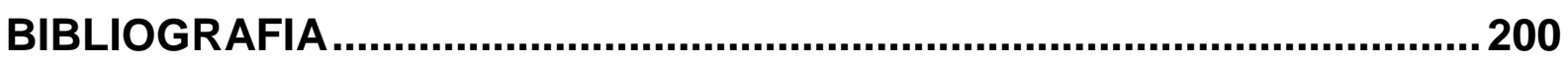


CAPÍTULO 1 INTRODUÇÃO 


\section{CAPÍTULO 1}

INTRODUÇÃO

\subsection{CONSIDERAÇÕES SOBRE O TEMA}

Etimologicamente, a palavra saúde provém da palavra holy e heal, pertencendo à mesma classe das palavras cura e bênção. Segundo a Organização Mundial da Saúde (1978), saúde é "[...] o estado de mais completo bem-estar físico, mental e social, e não apenas a ausência de enfermidade", reafirmando assim a origem da palavra. A edificação, que tem por objetivo abrigar os inúmeros serviços de assistência à saúde, é o hospital, uma tipologia que, segundo Martinez (2000), denominou-se, no séc. XIX, e que também é capaz de proporcionar um ambiente propício à cura.

Ao adentrar, no universo da arquitetura hospitalar, vê-se claramente que as evoluções pelas quais essa passou foram concomitantes aos avanços e descobertas da área médica, estando a arquitetura e a saúde, por meio da medicina, intrinsecamente relacionadas.

Desde a antiguidade, a arquitetura vem comportando as práticas médicas, auxiliando-as, no desempenho das atividades e inovando para suportar as novas tecnologias. O contexto histórico, social e econômico pelo qual a humanização passou, no período que compreende a Revolução Industrial e a Francesa, foram os grandes propulsores das transformações nas edificações destinadas à assistência à saúde, pois, mostraram a urgência em se ter novas estruturas que comportassem o aumento da procura.

Nos primórdios da edificação hospitalar, um papel de destaque reservava-se à arquitetura do hospital, como visto em Foucault (1998, p. 109), "A arquitetura do hospital deve ser fator $\mathrm{e}$ instrumento de cura [...] de mesmo estatuto que um regime alimentar, uma sangria ou um gesto médico". Tal papel de destaque enfatizou-se mais ainda com as inovações propostas pela enfermeira, Florence Nightingale, na Inglaterra.

\footnotetext{
* Revisão de Língua Portuguesa (legislação vigente) por Profa . Berta Beznosai, Mestre em Língua Portuguesa Aplicada.

* De acordo com a Associação Brasileira de Normas Técnicas. NBR 10520.
} 
As inovações propostas por Nightingale tiveram papel fundamental e decisivo na evolução dos hospitais. Os mais importantes aspectos incorporados por ela foram as questões básicas de assepsia, por meio do uso da luz solar. Provendo os ambientes de iluminação e ventilação natural, houve uma diminuição considerável de infecções e contaminações no ambiente. Os conceitos incorporados por Nightingale contribuíram muito para a humanização dos hospitais, transformando-os de um ambiente voltado à prática médica para uma instituição focada no enfermo.

A partir então, a arquitetura passa a ser considerada fundamental para a elaboração de um ambiente hospitalar adequado à cura.

O hospital, como instrumento terapêutico, é uma invenção relativamente nova, que data do final do século XVIII. A consciência de que o hospital pode e deve ser um instrumento destinado a curar aparece claramente em torno de 1780 [...]. (FOUCAULT, 1998, p. 99).

No entanto, em certo momento da evolução da arquitetura hospitalar, essa função deixa de coexistir, passando a coadjuvante do universo da saúde, restando à arquitetura suprir eficientemente as necessidades e exigências médicas e científicas, como o implemento de novas tecnologias. Desse modo, a evolução do edifício hospitalar se dá, no âmbito da planta física, com soluções espaciais para as questões técnicas como a flexibilidade estrutural, adaptabilidade, adequação dos fluxos e circulações, entre outros aspectos. Essas mudanças de ordem espacial acarretaram em um ambiente de alta complexidade, tendo como característica a desvalorização dos aspectos humanos.

A medicina abordava a doença e a saúde apenas a partir do corpo biológico individual, sendo os aspectos sociais, econômicos, culturais e psicológicos desconsiderados. Críticas vindas da antropologia e da sociologia vão inserir a doença em um novo contexto, relacionando-a a outros fatores que não só o fisiológico. (LUKIANTCHUKI; CARAM, 2008).

A humanização do ambiente hospitalar surge como uma resposta contra a minimização do aspecto humano, nesse hospital tecnológico, e tinha por objetivo melhorar a qualidade de vida dos usuários, no sentido de prover um espaço adequado às suas necessidades, não somente físicas, mas psicológicas, sociais e emocionais. Incorporada por uma equipe multidisciplinar, voltou-se o olhar para a psicologia ambiental, em que defendia a visão de o espaço influenciar no comportamento humano. 
Nesse sentido, a partir dos anos 50, estudos foram lançados aliados aos conceitos da percepção ambiental, fundamentais, no sentido de apoiarem as pesquisas feitas com o foco na saúde, para refletir sobre a qualidade dos elementos arquitetônicos do espaço como fator influente, no processo de reabilitação da saúde dos pacientes. As primeiras pesquisas realizadas foram com relação à iluminação natural, e os impactos causados sobre o sistema fisiológico dos pacientes, e, posteriormente, sobre os impactos psicológicos.

Mais recentemente, nas últimas décadas, esses estudos evoluíram e se destacou consideravelmente, no panorama mundial, principalmente por uma maior divulgação, coincidindo com a reformulação dos conceitos de concepção e de espaço hospitalar.

Paralelamente a esse movimento de reformulação da arquitetura hospitalar, entre os aspectos estudados dos elementos da arquitetura que influenciam no espaço, as cores se sobressaem. Dois pontos são importantes a serem considerados. $O$ primeiro refere-se aos investimentos feitos, na criação de centros e laboratórios de estudos de cor estudando a fundo o processo de formação da cor, suas características, métodos de ordenação, reprodução e aplicação. Consequentemente, houve uma propagação de institutos e associações focadas em reunir os conhecimentos produzidos de forma a incentivar e sistematizar as pesquisas e produções, e que por meio de congressos, reuniões, e outros encontros, ampliaram as discussões, ao passo que houve maior divulgação.

O outro ponto refere-se a uma vertente que buscou estudar as cores, no espaço arquitetônico, avaliando a sua inserção, as relações perceptivas espaciais e cromáticas e os impactos estabelecidos; também se voltaram para o ambiente hospitalar, avaliando os impactos das cores ao tratamento terapêutico de pacientes, buscando relações entre as cores e a saúde, por meio dos aspectos psicológicos, emocionais e físicos. Tais correlações entre cor, saúde e arquitetura já se verificam na antiguidade, portanto, nota-se um retorno aos conceitos de hospital como agente de cura e, por sua vez, as cores como elemento capaz de proporcionar as condições para essa função.

Essas iniciativas podem ser vistas a partir dos anos 90, afirma Malkin (2008). Alguns hospitais, timidamente, passam a incorporar tais conhecimentos à sua realidade. 
Primeiramente, as cores estiveram como elemento decorativo, estético e servindo de função para o zoneamento das áreas hospitalares. Mas, com os atuais avanços nos estudos e pesquisas na área, as cores tornaram-se elementos de composições complexas, havendo um salto considerável quanto às suas aplicações e funções de uso, essas baseadas em pesquisas que mostram características e comportamentos das cores no espaço.

As composições cromáticas, no ambiente hospitalar, receberam maior atenção e passaram a ser elaboradas consistentemente, desenvolvidas sobre aspectos conceituais e com métodos mais técnicos, para a concepção do espaço, resultando em uma integração mais direta entre a forma, a função e as cores do espaço projetado.

Os arquitetos que, já desde o início do processo de humanização da arquitetura hospitalar, haviam se colocado, no centro da articulação da equipe multidisciplinar, viram-se a trilhar caminhos desafiadores, quanto à inclusão das composições cromáticas tão incisivas no espaço hospitalar. O conhecimento das características físicas, a teoria, propriedades perceptivas, métodos e meios de aplicação das cores são essenciais para que o resultado final seja aquele pretendido e vá ao encontro das diretrizes estipuladas. Assim, o arquiteto incorporara à sua prática os conhecimentos acima, buscando ampliá-los.

Assim, o uso das composições cromáticas, no ambiente hospitalar, surge como uma solução para suprir as necessidades de estímulos visuais e proporcionar a sensação de bem-estar dos pacientes, visando suprir suas necessidades psicossocias, compondo esquemas complexos a serem estudos, deixando de ser aleatórios para serem transformadores de seres humanos. Na atualidade, o uso de composições cromáticas, como elemento arquitetônico capaz de reformular o ambiente hospitalar sob as diretrizes de propiciar a cura, o bem-estar e o desenvolvimento do ser humano ganharam tamanha importância que vem sendo uma das linha-guia para a projetação dos "Hospitais do Futuro", denominação dos hospitais que aliam a função de prevenir a doença, restaurar a saúde, exercer funções educativas e promover a pesquisa. 


\subsection{JUSTIFICATIVA}

Barach e Dickerman (2006) apontam que um dos maiores problemas para a recuperação de saúde dos pacientes é o stress hospitalar, e que em grande parte, o ambiente físico é um dos responsáveis pelo seu agravamento. $O$ stress se relaciona com os ruídos, com o sentimento de desamparo e a ansiedade que podem ser afetados pela pobreza de estímulos ambientais, com os aspectos funcionais e com o design complexo (NELSON; WEST; GOODMAN, 2005). Para Roger Ulrich (2000b), um dos estudiosos mais conceituados da área, tendo desenvolvido inúmeras pesquisas, o stress está conexo aos resultados negativos, na recuperação da saúde, ele ainda salienta que é prejudicial, com efeitos, nos âmbitos psicológicos, físicos e comportamentais, e que, por sua vez, podem agravar ainda mais os resultados do processo terapêutico.

O ambiente físico que visa auxilio à cura pressupõe um edifício que mostra a importância do indivíduo. Significa olhar para o usuário, do espaço construído, em todos os seus aspectos. Projetar, visando um ambiente hospitalar propício à cura é em si um aspecto integrado à totalidade do processo de concepção de um hospital, o design como outra ferramenta pode promover ou impedir que esse objetivo seja alcançado; mas poderá ser conseguido, considerando as características do ambiente físico, entendendo que esses interagem com o processo de cura por meio de caminhos fisiológicos e psicológicos.

Nesse contexto, promovendo o conceito de o ambiente físico agir, na cura, sugere que o bem-estar mental é necessário para o bem-estar fisiológico, e aquele é conseguido com um planejamento ambiental elaborado, apoiado em pesquisas que envolvem as percepções ambientais e análises clínicas. Estudos desenvolvidos por Ulrich (1984, 2000, 2002, 2004, 2008) e Haya Rubin, Pronovost e Diette (2001) do John's Hopkins Hospital apontam para isso, concluindo que o que de fato depende para a sensação de bem-estar é a capacidade de o ambiente apoiar a promoção à saúde, incorporando práticas no âmbito da arquitetura e do design hospitalar.

\footnotetext{
* A palavra design foi utilizada, neste trabalho, no sentido do projeto arquitetônico, que resulta em um espaço, a ser experimentado e vivenciado.
} 
O espaço construído hospitalar deve estar baseado, na percepção e aspectos cognitivos da relação ambiente x ser humano, que afeta respostas estéticas, afetivas, emocionais e psicológicas. Os estudos da neurociência e da psicofísica aplicados à arquitetura possibilitaram as constatações da inter-relação saúde $x$ ambiente, cabendo aos estímulos ambientais despertarem tais reações, na capacidade de extrair respostas fisiológicas a partir de respostas psicológicas, de acordo com Dilani (2003).

A interação do homem com o meio ambiente se dá através dos sentidos, e que para Del Rio (1996), dentre os sentidos que podem ser explorados, o sentido da visão é um dos mais importantes e o que fornece mais informações, conforme Arnheim (1988, 1995). Essa experiência imprime características únicas, na qual é possível distinguir profundidade, textura, cor, forma e brilho entre outras características. Nesse ponto, a cor coloca-se como um estímulo visual eficaz para a criação de respostas psicológicas, emocionais e fisiológicas (DILANI, 2003), tal como afirmam Billger e Anter (2006, p. 71, tradução nossa): "[...] para a arquitetura, a cor é um dos fatores mais importantes para criar valores emocionais, seja em um quarto ou em um edifício".

Assumindo uma característica cognitiva e representativa, na concepção do espaço arquitetônico, as cores passam a ser objetos de estudos, de real importância para o bem-estar e para a recuperação da saúde dos pacientes no ambiente hospitalar; sobre as características das cores Farina (2006, p. 13) expõe:

[...] a cor exerce uma ação tríplice: a de impressionar, a de expressar e a de construir. A cor é vista: impressiona a retina. E sentida: provoca uma emoção. E construtiva, pois, tendo significado próprio, tem valor de símbolo e capacidade, portanto, de construir uma linguagem própria que comunique uma ideia.

Considerando a capacidade transformadora das cores, desenha-se um novo panorama mundial, desafiador para os profissionais da área e servindo de embasamento para suportar as inovações de ordem projetual e conceitual do ambiente hospitalar. Esta pesquisa volta-se para esses estudos, dos aspectos das cores e suas reações, nos seres humanos, e, levantando as características compositivas para a sua aplicação no ambiente hospitalar, focada às implicações dessas relações. 
Diante do exposto, fica clara a necessidade de um aprofundamento nos estudos sobre as composições cromáticas, das características às suas implicações, no ambiente hospitalar, não excluindo uma discussão sobre as reações humanas frente ao seu uso e às transformações que o ambiente hospitalar passa atualmente, tendo em vista o foco central de promoção à saúde e ao bem-estar dos pacientes. Esta pesquisa coloca-se, no sentido de ampliar e divulgar essas discussões, vendo como uma oportunidade de ser uma contribuição para o desenvolvimento das relações humanas e do uso das cores, no ambiente hospitalar.

\subsection{OBJETO DE ESTUDO}

O objeto desta dissertação são as composições cromáticas aplicadas no ambiente hospitalar, tendo em vista as recentes reformulações pelas quais esse vem passando, impostas pela necessidade de se suprir, além das necessidades físicofuncionais, as psicossociais, visando a promoção à saúde e o bem-estar.

\subsection{OBJETIVOS}

Esta dissertação tem por objetivo geral apresentar um estudo das cores, desde o seu processo de formação até as suas características perceptivas e físicas, para comporem esquemas cromáticos; discutindo a aplicabilidade na arquitetura hospitalar, especialmente, como um instrumento de transformação do design hospitalar e das relações estabelecidas entre usuários e ambiente, a partir do levantamento dos aspectos cognitivos e das possíveis implicações que podem exercer no comportamento do ser humano.

Tem ainda como objetivos específicos:

1. Discutir o posicionamento do profissional arquiteto frente ao processo de transformações do ambiente hospitalar, sobretudo as suas atribuições frente às variações de percepção espacial. 
2. Identificar os esquemas de composições cromáticas que possam auxiliar, no processo terapêutico de pacientes hospitalares, tendo em vista as questões relativas ao conforto visual e ao bem-estar psicológico.

\subsection{METODOLOGIA}

Buscando alcançar os objetivos propostos por esta dissertação, a metodologia consistiu em uma abordagem de natureza descritiva, empregada a partir de uma ampla pesquisa bibliográfica e iconográfica, e que foi sistematizada, na apresentação de três casos que ilustram as principais questões sobre o uso de composições cromáticas no ambiente hospitalar.

No entanto, para o desenvolvimento do tema da dissertação, notou-se a necessidade de se ampliar os campos de conhecimento estudados, não se restringindo às características das cores, que formaram o pano de fundo para o desenrolar da pesquisa e sustentação da base teórica referencial.

\subsubsection{Revisão Bibliográfica}

A revisão bibliográfica representou uma das etapas mais importantes, formando a base teórica da pesquisa. Nessa etapa a pesquisa foi dividida em áreas de estudo, e primeiramente, buscou-se levantar a bibliografia dos principais conceitos abordados na dissertação.

Dentre os assuntos levantados, nessa primeira etapa, foram os estudos, acerca das concepções de espaço, abordadas por Lynch (2001), Bachelard (1993), Tuan (1983) e Hall (1977), e as discussões, empreendidas por Veiga (2006, 2008), sobre desenvolvimento e meio ambiente. Nessa primeira fase, também constituíram as fundamentação teóricas, a literatura sobre cor, encontrada em Arnheim (1995), Goethe (1993), Mahnke (1996), Rossoti (1985), Itten (1970), Linton (1999), Birren (1978) e Swirnoff (2003).

Uma vez fundamentada a base teórica geral, partiu-se para o levantamento bibliográfico das questões específicas, e dividem-se na seguinte forma: 
1. Estudo sobre as cores:

a. O entendimento da formação das cores, das suas características (físicas, simbólicas e perceptivas) e das conceituações e teoria;

b. Questões da percepção cromática e as correlações das cores nos âmbitos das simbologias e reações humanas;

c. Definição de esquemas cromáticos, instrumentos e métodos de composição.

2. Estudo das cores aplicadas na Arquitetura:

a. Levantamento das características, funções e métodos de aplicação das composições cromáticas na arquitetura;

b. Estudo dos aspectos envolvidos, na percepção ambiental e visual, e consequentes relações com a percepção cromática.

c. Levantamento histórico sobre o uso e o papel desempenhado das cores na arquitetura, focado na arquitetura hospitalar.

3. Estudo sobre a Arquitetura Hospitalar:

a. O embasamento para a discussão sobre as transformações no ambiente hospitalar, deu-se a partir do estudo da evolução da arquitetura hospitalar e do processo de humanização, o qual permitiu verificar que atualmente o hospital volta-se aos conceitos iniciais dos lugares de cuidados à saúde.

b. Levantamento de conceituações sobre as noções de espaço, de conforto ambiental e das simbologias relacionadas ao ambiente hospitalar;

c. Correlações entre cor, saúde e ambiente hospitalar, que primeiramente envolveu estudos sobre as questões das influências do ambiente construído no processo de tratamento terapêutico de pacientes hospitalares; 
d. Levantamento de conceitos e diretrizes para o projeto do edifício hospitalar, focado no ambiente interno, decorrente da humanização do ambiente hospitalar.

Em relação à temática um e dois, que consiste no estudo sobre as cores e a aplicação dessas, na arquitetura, constatou-se que a produção literária é ampla e dedicada a vários aspectos e características das cores; em livros de conforto ambiental, são dedicados capítulos às questões que envolvem a cor, dos quais muitos serviram de base para os assuntos abordados nos Capítulos Dois, Três e Cinco.

É, na literatura internacional, que está a maior parte do material utilizado, uma vez que a quantidade de produções é muito maior, principalmente aquelas provenientes de produções acadêmicas e científicas, decorrentes de pesquisas desenvolvidas em laboratórios e centros de estudos de universidades.

Para o estudo das questões de aplicabilidade das cores na arquitetura, e as características que a envolvem, os aspectos mais relevantes foram encontrados em proceedings de Congressos Internacionais ou em artigos e papers de autores suecos.

Para o desenvolvimento da temática três, que compreendem os estudos sobre a arquitetura hospitalar, as questões perceptuais que a envolvem e o processo de humanização que vem focando, no uso de composições cromáticas, os materiais mais relevantes foram encontrados em produções provenientes dos Estados Unidos; com contribuições importantes a respeito da sustentabilidade e dos mais novos conceitos para a projetação do ambiente hospitalar, e os seus impactos, no processo terapêutico de pacientes hospitalares, que orientaram as formulações dos Capítulos Seis e Sete.

\subsubsection{Material Iconográfico}

Esta etapa consistiu em coletar material que possibilitasse ilustrar os conceitos abordados, e representou parte fundamental para o aspecto descritivo desta dissertação. 
A pesquisa iconográfica buscou coletar imagens, que complementassem as informações obtidas no levantamento bibliográfico, principalmente, para os Capítulos Cinco, Sete e Oito, que tratam de aspectos relativos a aplicabilidade da cor através das composições cromáticas. Assim, para cada item, buscou-se relacionar o conteúdo abordado a imagens representativas. A escolha do material iconográfico seguiu alguns critérios, como:

- Relevância com o tema;

- Projetos de fontes primárias, buscando a interpretação e a análise dos autores;

- Projetos representativos de fontes relevantes e de reconhecimento nas áreas em questão;

\subsubsection{Apresentação de Casos}

O Capítulo Oito apresenta a exemplificação da aplicação prática de composições cromáticas no ambiente hospitalar, a partir do levantamento de três casos.

A definição dos casos, a serem apresentados, partiu de uma busca guiada no princípio de que, os exemplos a serem ilustrados de hospitais construídos ou idealizados, representassem em sua totalidade, os conceitos encontrados nos Capítulos Quarto, Quinto e Sétimo; dessa forma, restringiu-se o universo de projetos hospitalares passíveis de representaram os casos.

Foi através de um levantamento feito, nas instituições ligadas ao desenvolvimento do edifício hospitalar, nas principais publicações da área e nos centros de estudos da cor, que se encontraram os exemplares que poderiam ilustrar os casos, sendo eles:

- Royal Hospital for Sick Children, Escócia.

- Karollinska Solna University Hospital, Suécia.

- Children's Hospital of Pittsburgh of UPMC, Estados Unidos.

- PSE\&G Children's Specialized Hospital, Estados Unidos.

- Montefiori Medical Cente, Estados Unidos. 
- Bristol Royal Hospital of Children, Reino Unido.

- King's Mill Acute Care Hospital PFI, Reino Unido.

Com os dados levantados, de cada um desses hospitais, foi feita uma análise sobre o papel que as composições cromáticas desempenhavam nos projetos, avaliando os métodos projetuais, as diretrizes estabelecidas, o desenvolvimento projetual, o projeto arquitetônico e o espaço resultante.

A partir da avaliação e análise, foram considerados, como exemplares capazes de representar os conceitos abordados e ilustrar de forma consistente a questão cromática no ambiente hospitalar, focada em auxiliar o tratamento terapêutico dos pacientes e promover o bem-estar, os seguintes hospitais:

- Royal Hospital for Sick Children, Escócia.

- Karollinska Solna University Hospital, Suécia.

- Children's Hospital of Pittsburgh of UPMC, Estados Unidos.

Para que o levantamento dos dados (bibliográfico, iconográfico e dos casos) tivesse o alcance obtido, foi necessário expandir a pesquisa para além das fontes encontradas nas bibliotecas. Assim, cabe ressaltar que a ferramenta da internet, como meio de pesquisa, foi fundamental para esta dissertação, possibilitando o acesso a inúmeros papers, artigos científicos, produções acadêmicas, proceedings, relatórios de pesquisas, além de e-books, e jornais científicos, mundial.

Muito dos assuntos levantados neste trabalho, apresentam temas recentes, que ganharam maior divulgação com a possibilidade da interação entre as produções, divulgação dos resultados e informação globalizada.

As principais referências científicas, da maior parte dos assuntos abordados nos Capítulos Quatro, Cinco e Sete, encontram-se na literatura dos países escandinavos, e o acesso a elas foi possibilitado pela ferramenta da internet, que constituíram literatura essencial para o desenvolvimento deste trabalho, com informações recentes e atuais. 


\subsection{ESTRUTURAÇÃO DO TRABALHO}

O Capítulo Dois dedica-se a uma apresentação do sistema visual e do processo de formação das cores. Destaca os aspectos envolvidos na percepção visual e discorre sobre as diferenças entre a percepção das cores e a sensação de cores.

O Capítulo Três apresenta a Teoria das cores, suas propriedades físicas e descritivas. Trata dos tipos de misturas de cores e dos sistemas de notação cromático.

No Capítulo Quatro são levantadas as questões relativas às simbologias e associações, estabelecidas com as cores, e apresentadas pesquisas sobre os efeitos dessa nas reações humanas. Ressalta as pesquisas realizadas sob a disciplina da psicofísica e destaca uma recente abordagem de estudo das cores. Neste Capítulo são, efetivamente, discutidas as relações entre as reações humanas e as cores.

No Capítulo Cinco são colocadas as questões práticas do uso das cores aplicada à arquitetura, discutindo as relações estabelecidas, e apresenta características perceptivas dessas relações. Aborda a percepção espacial como pano de fundo para a realização dessas relações e introduz um relato histórico sobre como se deu o uso das cores na arquitetura.

O Capítulo Seis adentra no universo da arquitetura hospitalar, apresentando as principais evoluções, mundial e nacionalmente. Relaciona a arquitetura hospitalar, a saúde e as cores. Reflete sobre como o espaço arquitetônico vem participando do processo de humanização no hospital e do processo terapêutico dos pacientes, colocando novas conceituações.

O Capítulo Sete reflete sobre o uso das composições cromáticas no ambiente hospitalar. Apresenta os possíveis usos e funções das cores no hospital, e aponta diretrizes para a formulação das composições cromáticas e seus meios de aplicação.

O Capítulo Oito representa uma exemplificação prática dos assuntos discorridos nos demais Capítulos. Ilustra três projetos, em que se reflete sobre o uso das composições cromáticas, os meios, métodos e características de aplicação, em 
hospitais. Apresenta o cenário atual sobre os conceitos envolvidos nas diretrizes projetuais da arquitetura hospitalar, e salienta a discussão sobre as transformações do espaço hospitalar como elemento de cura.

As considerações finais constituem o Capítulo Nove. Que expõem as reflexões resultantes da pesquisa. Propõem temas para futuros trabalhos e apresenta diretrizes para composições cromáticas no ambiente hospitalar. 
CAPÍTULO 2

FORMAÇÃO DAS CORES:

VISÃO E PERCEPÇÃO 


\section{CAPÍTULO 2 FORMAÇÃO DAS CORES: VISÃO E PERCEPÇÃO}

\subsection{PERCEPÇÃO VISUAL}

O esclarecimento e compreensão do processo de percepção visual se fazem de relevante valor para o tema da dissertação. O hospital lida com a pluralidade de usuários, serviços, espaços e valores e, sendo a percepção visual um processo em que supõe o recebimento de uma informação que, para ser codificada, adentra no âmbito das experiências pessoais e individuais, tal estudo se torna fundamental.

Partindo dos conceitos da percepção ambiental, considera-se que a visão é um dos mais importantes órgãos de recepção de informações (DEL RIO, 1996), e que, através dela, é possível conhecer o mundo. Arnheim (1988) afirma que os elementos que compõem o espaço como formas, texturas, cores, brilhos e profundidade é que agem primeiramente, no processo de percepção, pois, para ele, os estímulos visuais são os primeiros no processo. Zanettini (2002, p. 451) sobre o assunto reflete: "O homem moderno é visual. O olhar assume então um papel catalisador do conhecimento, devendo, portanto, ser treinado. Educar o olhar é perceber o que está ao redor. Perceber pressupõe compreender".

Portanto, os conceitos da percepção visual serão abordados considerando que a priori do processo perceptivo ambiental tem-se o processo visual.

No campo da percepção visual, é no espaço que o ser humano está inserido e onde desenvolve suas ações, seja qual for o espaço construído, a ligação dele com o ambiente é tão estreita que além de acolher suas necessidades físicas de abrigo também estabelece um relacionamento de expectativas e desejos, criando uma interação e inter-relação (DEL RIO, 1996). As ações humanas ocorrem no espaço de uma forma como resposta a ele. Sobre essa questão, Gaston Bachelard (1993) considera que o espaço é um vazio e é neste vazio o homem exerce seu ser.

O processo de percepção visual, ou seja, a capacidade de ver tem como ponto de partida o estímulo, seja qual for a fonte, é o elemento desencadeador do processo visual. Segundo Anter (2000), o papel do estímulo é gerar sensações, essas 
suscitadas a partir da absorção do estímulo pelos órgãos sensoriais. Tratando-se da percepção visual, o sentido da visão é acionado através do olho; órgão responsável e diretamente relacionado à recepção dos estímulos visuais.

Seja uma fonte luminosa, um objeto qualquer, uma linha, uma paisagem, um som, entre tantos outros possíveis, é o que possibilita verificar a existência das inúmeras fontes de estímulos. Para a percepção visual, alguns estímulos são mais direcionados e eficazes que outros, como apontam estudos da psicologia ambiental. Arnheim (1995, p. 4) cita o ponto, a linha, a borda, a profundidade e a textura, como estímulos visuais, ressaltando a diversidade. A partir dessa constatação, parte um conceito que permeia todas as suas obras, a qualificação da experiência visual como dinâmica.

Os estímulos, uma vez detectados pelos receptores sensoriais, transformam-se em impulsos nervosos que são enviados ao cérebro. Até este ponto, podemos dizer que se tem a sensação, como afirma Wayne Weiten (2002, p. 93): "A sensação é a estimulação dos órgãos do sentido, ou seja, temos a sensação quando absorvemos qualquer tipo de energia, como, por exemplo, a luz, o som, pelos órgãos como o olho e os ouvidos", a figura abaixo sintetiza o processo visual.

Somente quando esses impulsos são enviados ao cérebro é que realmente ocorre a codificação dos estímulos em significados. Portanto, conclui-se que o cérebro, desempenha papel fundamental no processo visual (HUBEL, 1995; WEITEN, 2002). É a partir dele que os estímulos são organizados, selecionados e traduzidos em algo significativo e é, nessa etapa, que consiste a percepção.

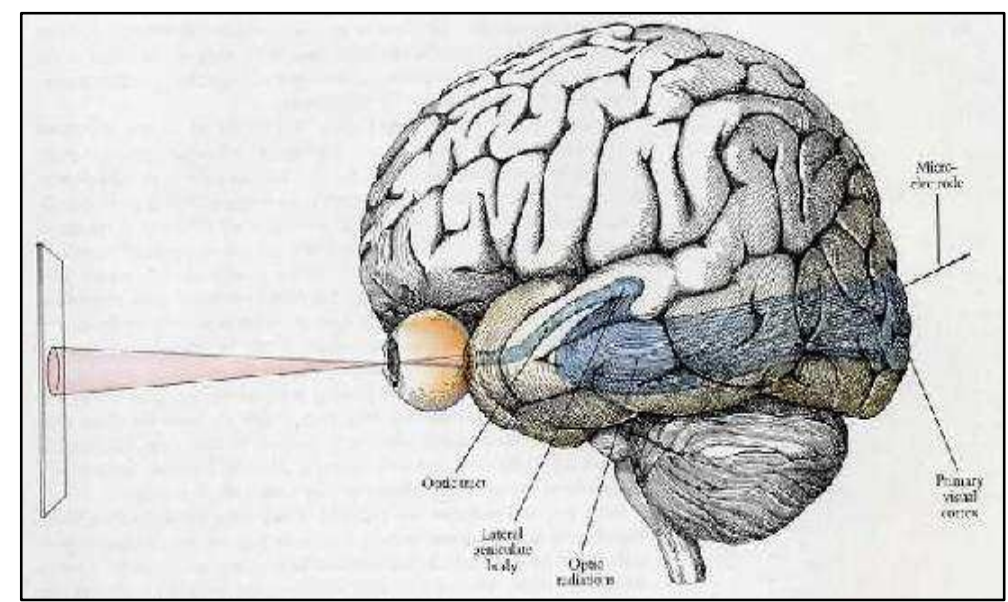

Figura 1 - Processo Visual. Fonte: HUBEL, 1995. 
Conforme acima descrito, o processo visual passa primeiramente pelo âmbito da sensação e posteriormente pelo da percepção. Os dois processos fundem-se, no ponto onde os receptores sensoriais convertem a energia em impulsos nervosos, esse processo é estudado por inúmeros pesquisadores, entre eles se destacam Hubel e Wiesel (1995), premio Nobel de medicina em 1981. Os resultados de suas pesquisas foram determinantes para a compreensão do sistema visual e aprofundamento dos estudos sobre a visão das cores.

Nota-se, portanto, que existe uma distinção entre ver as cores e perceber as cores; tema que será aprofundado visando à compreensão total dos aspectos que englobam a percepção cromática espacial.

Perceber não é necessariamente ver. Isso tem uma importância considerável para o homem uma vez que a palavra "cor" e "ver" são utilizadas na nossa linguagem muitas vezes erroneamente. Além do que, ver, no próprio sentido da palavra é obter uma imagem com um significado óptico do termo, ou seja, estabelecer uma relação topológica entre os pontos do espaço exterior e os pontos do órgão sensível para a recepção das radiações [o olho]. (GRANADO, 2009, tradução nossa, grifo do autor).

\subsubsection{A Sensação de Cor versus a Percepção Cromática}

O sistema visual humano é complexo e apresenta suas particularidades, entre eles, a diferença entre sentir e perceber. Uma discussão que permeia diversos campos do conhecimento, como a ciência, a psicologia, a medicina e tantos outros que através de estudos, teorias, conceitos e hipóteses tentam delinear suas diferenças.

A percepção das cores, conforme conceitua Berns (2000), se dá, principalmente, pela reflexão da luz das superfícies, ao invés, da luz direta emitida por fontes luminosas. Quando a luz atinge um determinado objeto três coisas possíveis podem acontecer (Figura 2), Michel (1995) explica:

[...] a primeira é que a luz pode ser absorvida e a energia convertida em calor, como quando o sol esquenta alguma coisa; segundo, ela pode atravessar o objeto, assim como os raios solares batem a água ou um copo; terceiro, ela pode ser refletida, como no caso de um espelho ou um objeto colorido, como um pedaço de giz. 


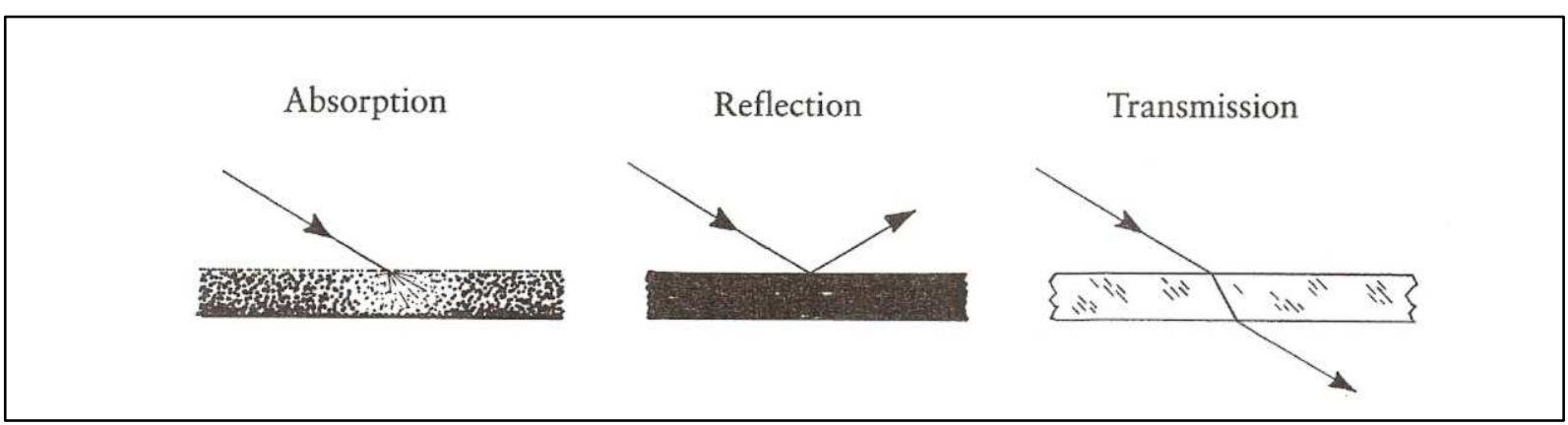

Figura 2 - Representação dos raios de luz em uma superfície.

Fonte: MICHEL, 1995

Na maioria dos casos, todas ou duas das possibilidades mencionadas, acontecem, por exemplo, alguma luz pode ser absorvida e alguma refletida (Figura 3). Um objeto que absorve alguma quantia de luz e reflete o resto é chamado de pigmento (BERNS, 2000); se um determinado comprimento de onda, na gama de luz visível, for absorvido mais que outro, o pigmento colorido se aparecerá na cor relativa ao comprimento de onda dominante. No entanto, a percepção das cores está relacionada com as três propriedades da luz, citadas acima, e, conforme assinala Weiten (2002), com as complexas combinações entre elas.
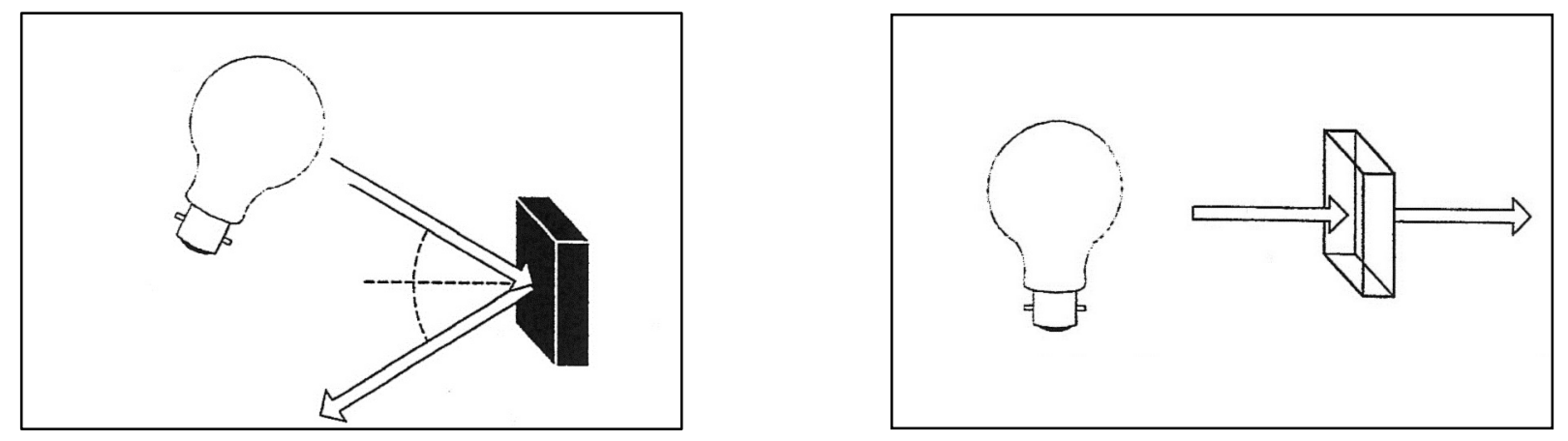

Figura 3 - Reflexão e Absorção da luz..

As imagens acima representam os caminhos possíveis da luz. Na imagem, à esquerda, a luz é em parte absorvida pelo objeto, e parte refletida, assim tem-se um objeto opaco, ou seja, não há a transmissão de luz através do objeto; a imagem, à direita, a luz que atinge o objeto é transmitida para o outro lado, nesse caso, o objeto em questão, é transparente. Fonte: BERNS, 2000.

Portanto, como primeiro passo para a visão e percepção de cor, é a existência da luz; sendo verdadeiro afirmar: "[...] sem luz não há cor” (BAKER, 2002, p. 9, tradução nossa).

Entretanto, o próprio conceito do que é luz, parece ser contraditório. Segundo Anders Liljefors (apud ANTER, 2000, p. 90) existem diferenças em relação ao conceito de luz; a luz pode ser entendida como a experiência com o sentido visual, outra designação é que luz consiste, na radiação eletromagnética, no intervalo de comprimento de onda de 380-780nm, que se chama luz visível. Para muitos autores, 
é importante esclarecer essas diferenças tornando a compreensão do tema mais clara.

A pesquisadora sueca, Karin Fridell Anter, apresenta outros aspectos que envolvem conceitos de luz e cor, tornando o tema ainda mais complexo. Segundo ela, a causa da percepção de cor é o estímulo, termo usado para descrever vários eventos. 0 estímulo é definido, por ela, de três formas: Proximal stimulus define a radiação energética que alcança e ativa os receptores da retina nos olhos; enquanto que distal stimulus é a radiação energética que é emitida, transmitida e refletida de um objeto. Soma-se aos conceitos acima descritos outro termo, o stimulus, que pode referir-se ao próprio objeto. Conforme ela menciona, esse último conceito é a descrição utilizada nos experimentos psicológicos que envolvem a percepção.

\footnotetext{
Uma distinção clara entre coisas que são fonte de estímulos [...] e o 'stimuli' propriamente. $O$ anterior são objetos, eventos, superfícies, lugares, substâncias, figuras e outros animais. $O$ último são padrões e transformações de energia nos receptores. $O$ 'stimuil pode especificar a sua fonte, mas, não é, claramente, a mesma coisa que a fonte. (GIBSON, apud ANTER, 2000, p. 29, tradução nossa).
}

Assim, também é polêmica a discussão sobre o que é cor. O psicólogo, James J. Gibson, que se dedicou aos estudos de percepção visual, define cor como sendo: [...] uma qualidade intrínseca do objeto, qualidade esta que impropriamente é chamada de pigmentação, mas que ele a descreve como espectro refletido das superfícies [...] (GIBSON, apud ANTER, 2000, p. 30, tradução nossa).

Baker (2002) aborda a questão da sensação de cor, que para ele, é a absorção de uma parte do espectro pelo pigmento ou tinta, e a reflexão das partes remanescentes. Berns (2000) salienta que, mais importante que descrições sobre o que é cor, seja ela uma forma de luz ou o seu efeito, no olho humano, é o resultado desse efeito na mente.

Para ele, no processo de percepção visual cromático, cada fase corresponde a um determinado órgão ou área de conhecimento: "O resultado da modificação física da luz pelos colorantes é detectado pelo olho humano (chamado processo 'response) e interpretado pelo cérebro (chamado processo perceptivo, que introduz a psicologia)", portanto, conforme afirma: "[...] a cor é mais que alguma coisa física, é aquilo que 
vemos". Sobre essa visão, Weiten (2002, p.101) enfatiza: "[...] é uma interpretação psicológica, não uma propriedade física da própria luz".

Os conceitos levantados acima abrem outro campo de estudo sobre a cor; não seu funcionamento, suas teorias de harmonia, composições e misturas, mas, em outro sentido. Um sentido mais abstrato: o dos significados e o das impressões que as cores causam, no ser humano, mais especificamente, na mente. Portanto, como cada ser humano interage com determinadas cores, quais as analogias, as simbologias e os arquétipos relacionados a elas, constitui-se uma dicotomia, a sensação de cor e a percepção das cores.

Pedrosa (1989, p.18) remetendo ao assunto diz:

[...] o fenômeno da percepção da cor é bastante mais complexo que o da sensação. Se nesta entram apenas os elementos físicos (luz) e fisiológicos (o olho), naquela entram, além dos elementos citados, os dados psicológicos que alteram substancialmente a qualidade do que se vê.

Para Matlin e Foley (apud ANTER, 2000, p. 32, tradução nossa), a distinção é: "A sensação refere-se à experiência básica e imediata gerada por estímulos isolados, simples. Em contrapartida, a percepção envolve a interpretação dessas sensações, dando então a significação e organização". Já Anders Hård (apud ANTER, 2000, p.33, tradução nossa) distingue entre ver cor, como uma parte de um objeto, e, perceber cor, como um fenômeno independente; para Hård, a percepção é algo espontâneo e não pressupõe nenhum processo intelectual, pois, não a considera como a soma de várias sensações.

Alguns estudiosos discordam da concepção de que a radiação energética relacionase com a percepção da cor, segundo eles, não há inter-relação; Steven Shevell (apud ANTER, 2000, p. 34) considera que: "[...] a visão das cores está situada, no cérebro, e não, no olho, então, não é correto falar, em radiação azul e vermelha".

No entanto, Schopenhauer (2003, p. 53, tradução nossa) considera que toda e qualquer experiencia visual está relacionada ao intelecto, conforme afirma: "[...] é doutrina indubitável, da fisiologia, que toda sensibilidade nunca é pura passividade, mas, reação a um estímulo recebido". 
Schopenhauer (2003, p. 29, tradução nossa) salienta:

[...] a visão é intelectual, pois sem o intelecto jamais haveria visão, percepção ou apreensão de objetos, nos restaria a mera sensação de que, como dor ou bem-estar, poderia ter quando muito um significado em relação à vontade, mas seria apenas uma alternância de estados vazios de significado, em nada semelhante ao conhecimento.

Já para Merleau-Ponty (apud ANTER, 2000, p.37), a cor é parte de uma totalidade indivisível e só é percebida, conscientemente, quando for diretamente pertinente para a atividade imediata, portanto, para ele, a percepção de cor depende totalmente de nosso propósito de observação:

Um motorista de carro vê as cores do semáforo e está imediatamente
consciente sobre as mudanças delas, e ao mesmo tempo está atento nos
outros veículos na estrada, seus os movimentos e tamanhos. Porém,
frequentemente o motorista não tem nenhuma ideia da cor do carro que o
incitou a pisar nos freios. Tal elemento, a cor do carro, é irrelevante para a
situação e não é incluído na percepção consciente. Um motorista que passa
por um prédio conhecido dele que tenha sido repintado poderia notar a nova
cor, mas poderia não ser capaz de recordar como o edifício era antes que
fosse pintado. (MERLEAU-PONTY, apud ANTER, 2000, p. 37 , tradução
nossa). Com relação a essa visão, Anter (2000) concorda que a cor percebida é influenciada pelas intenções, referências, conhecimentos e expectativas do observador, pois, como ela aponta, duas pessoas podem ver duas cores diferentes, mesmo se as circunstâncias externas são idênticas; também significa que as pessoas podem ver cores distintas, mudando de posição ou de atitude de observação.

Logo, no âmbito das percepções elas podem ser parecidas, iguais ou distintas, variando de pessoa para pessoa, conforme a cultura, a tradição e o habitat. Tuan (1980) ressalta que, além das questões culturais, existem as questões individuais, as quais contribuem, ativamente, para as variações de percepção. No caso, a memória de outros estímulos entra em ação, comparando e recriando, através de suas experiências anteriores. Contudo, Del Rio (1996, p. 3) contrapõe a ideia de que a percepção é exclusivamente individual, para ele: "[...] embora mesmo as percepções sendo subjetivas para cada indivíduo, admite-se que existem recorrências comuns, seja em relação às percepções e imagens, seja em relação às condutas possíveis". 
Assim, como apresentado, a percepção é variável de pessoa para pessoa, por envolver influências individuais, tais como experiências de vida, estado emocional e intenções, e influências coletivas, tais como questões culturais; esses fatores desempenham papel determinante, na cognição do ambiente, ou seja, como se vê e como se relaciona com o ambiente.

O edifício hospitalar abriga tamanha diversidade que se torna um desafio projetá-lo, no âmbito das percepções, porém, conhecendo os aspectos que envolvem os processos perceptivos, que foram brevemente, torna tal tarefa mais simples e também, mais precisa. Atualmente, o design do edifício hospitalar apresenta diretrizes específicas, que saem da esfera do aspecto físico do edifício, e entram, no âmbito do indivíduo, especificamente, do paciente.

O foco do projeto hospitalar, atual, está, no bem-estar do paciente e no conforto ambiental dos espaços, buscando suprir as necessidades psicológicas, emocionais e sociais dos usuários e, todas encerram, de certa forma, uma relação usuárioambiente mais pessoal e mais valorizada. Será acrescido a esse assunto a percepção das formas, ou seja, a percepção espacial e que, juntas, podem delinear atuações mais precisas e conceituadas, das composições cromáticas, no ambiente hospitalar.

\subsection{O SISTEMA VISUAL}

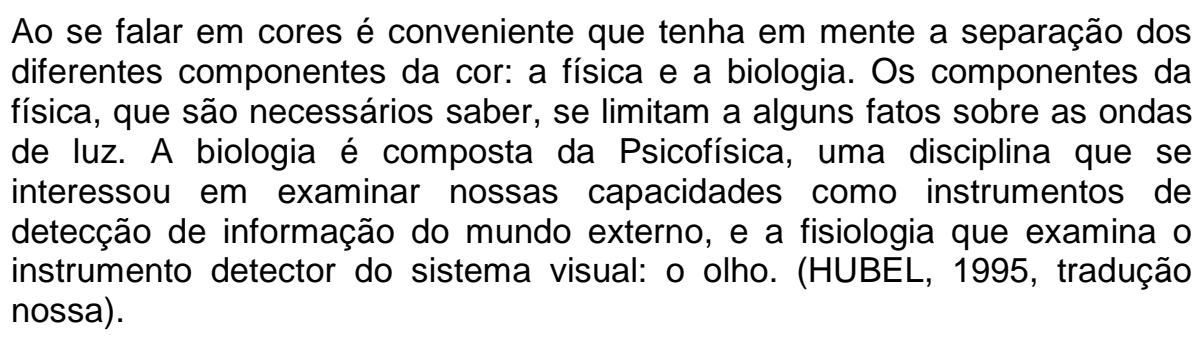

Para Hubel (1995), sabe-se muito sobre as características, físicas e as psicofísicas, das cores, mas a fisiologia ainda está relativamente, nos primeiros estágios de nossos conhecimentos. Conhecer o funcionamento do órgão da visão, dos processos cerebrais e hormonais é parte do conhecimento do processo de percepção visual e da visão das cores. O mecanismo da percepção cromática é complexo, e para compreender com mais amplitude as implicações do uso das cores 
na arquitetura, é necessário adentrar um pouco, no campo da ciência, que está por trás da visão das cores. Assim, nos próximos itens, serão abordados e apresentados os elementos e aspectos que constituem o sistema visual humano e que participam do processo de percepção das cores.

Arnheim (1995) introduz o tema quando defende que a luz tem papel essencial na formação do sistema visual. Ele aborda a luz como sendo não só uma causa física, mas como uma experiência psicológica, e que tal experiência é fundamental, como afirma:

Se quiséssemos começar com as primeiras causas da percepção visual um exame da luz devia ser precedido todos os outros porque sem luz os olhos não podem observar nem forma, nem cor, nem espaço ou movimento. Tal posicionamento condiz com tantos outros estudos sobre o sistema visual. (ARNHEIM, 1995, p. 293).

Partindo dessas afirmações acima, o estudo do sistema visual começará a partir da luz.

\subsubsection{Estímulo Primordial: A Luz}

Sem o olho,

Como veríamos a luz? Sem a força de Deus vivendo em nós, Como o divino nos seduz.

(GOETHE, 1993)

Goethe (1993) também foi um dos que mais enalteceram o papel da luz, no processo de percepção visual, como fator desencadeador do processo, no entanto, a sua abordagem ampliava-se para uma questão mais platônica e filosófica.

A luz é uma forma de energia eletromagnética que viaja como uma onda, as ondas podem variar em amplitude e comprimento, aquela afeta principalmente a percepção do brilho, enquanto o comprimento afeta a percepção da cor (BERNS, 2000). Essa energia eletromagnética que entra, nos nossos olhos e atua, em fotorreceptores, localizados, na retina, desencadeia processos que estão, na base da geração de impulsos nervosos e são conduzidos por vias e redes neuronais do sistema visual ao cérebro. 
Contudo, somente uma parcela do espectro da energia é visível ao olho humano, essa parcela é denominada de luz visível, a qual possui ondas de comprimento entre 400 e 800 nanômetros aproximadamente e fica entre os raios ultravioleta e infravermelho. O espectro da luz visível, quando decomposto, apresenta ondas com diferentes comprimentos e que correspondem às cores do arco-íris (vermelho, alaranjado, amarelo, verde, azul, anil e violeta).

As cores mais quentes (amarelo ao vermelho) têm maior comprimento de onda enquanto as mais frias (verde ao violeta) menor comprimento de onda. A figura 4 ilustra o espectro visível da luz, na qual constam os demais tipos de radiações, separados por suas frequências.

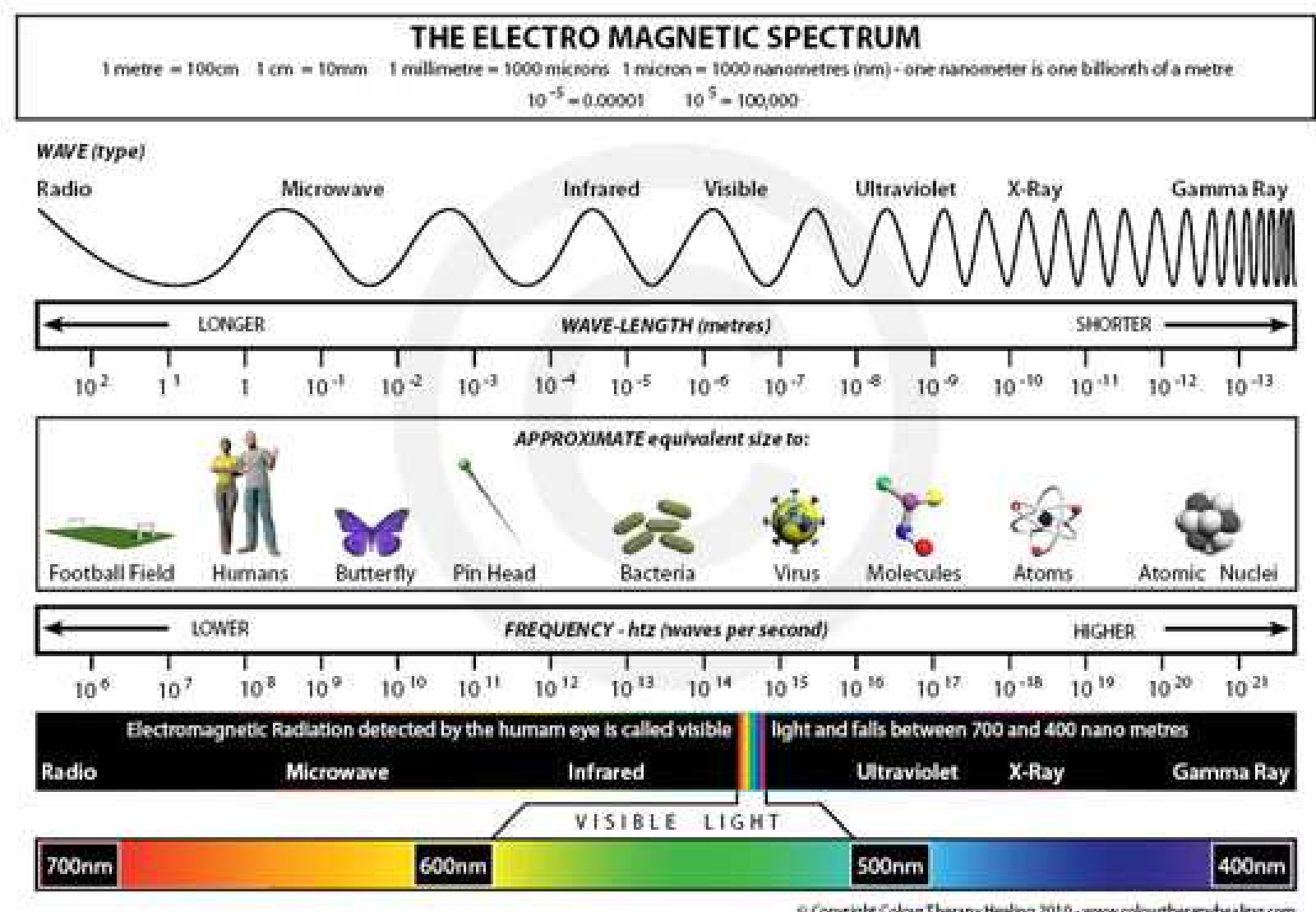

Figura 4 - A luz visível e as cores.

Fonte: www.colourtherapyhealing.com.

Sendo a luz uma energia radiante, ela é medida em ondas. Uma das suas características físicas é que quanto menor o comprimento da onda, maior será a frequência e a quantidade de energia e quanto maior o comprimento da onda, menor sua frequência, logo, menor quantidade de energia (WEITEN, 2002). 
Mais de que uma forma de radiação eletromagnética, a luz é um estímulo psicológico, acentua Arnheim (1995); a luz tem um impacto psicológico e fisiológico significativo no homem. Quando a luz passa pelos olhos, os impulsos são propagados não apenas às várias áreas visuais, mas também, às áreas do cérebro relativas às emoções e à regulação hormonal.

O papel da luz, na visão humana, extrapola os conceitos da física, entra, no domínio da psicologia, da fisiologia e da filosofia. Não é objeto de estudo dessa dissertação e, portanto, o tema não será aprofundado além do necessário para o entendimento da visão das cores e suas características. Contudo, cabe ressaltar que, assim como as cores, a luz, no ambiente hospitalar, é um elemento do design capaz de auxiliar no processo terapêutico de cura e qualificar o ambiente, emocional e simbolicamente; aspectos, considerados por Costi (2002) e Guzowski (1999), relevantes para os usuários desse ambiente.

\subsection{2 Órgão da Visão: O Olho}

O olho é o órgão que abriga o receptor dos estímulos visuais. O receptor é chamado de retina e é a responsável por captar os estímulos provenientes da luz. As principais estruturas que participam ativamente, no processo da visão, são a íris, lente, pupilas, córnea, retina, humor vítreo, disco óptico e nervo óptico.

A luz percebida entra pela córnea, ela juntamente à lente do cristalino formam uma imagem invertida do objeto percebido, na retina. A lente do cristalino, que focaliza os raios de luz, é formada por um tecido transparente, é a responsável pelo processo de acomodação do olho; a curvatura da lente se ajusta para alterar o foco visual. A maioria dos problemas visuais é causada por defeitos ou problemas, na lente ou no processo de acomodação.

Da mesma forma, o olho faz ajustes para controlar a quantidade de luz que entra e atinge a retina. A luz atravessa a córnea e passa pela íris, por meio de uma abertura no centro chamada pupila; essa estrutura é que possibilita controlar a quantidade de luz que passa e atinge a retina. Esse funcionamento, de regulagem de quantidade de luz, é importante para que se possa entrar mais luz no caso da escuridão, 
quando há a dilatação da pupila; ou menos luz quando houver muito estímulo, por exemplo, uma luz forte, quando há a contração da pupila.

Quando a luz atinge a retina, é que se inicia o processo de transmissão dos estímulos (Figura 5). A retina é a responsável por absorver a luz, processar a imagem e enviar a informação visual ao cérebro. Na figura 6 , a retina é representada com seus componentes, que, basicamente, resumem-se, em células nervosas e nos fotorreceptores (WEITEN, 2002).

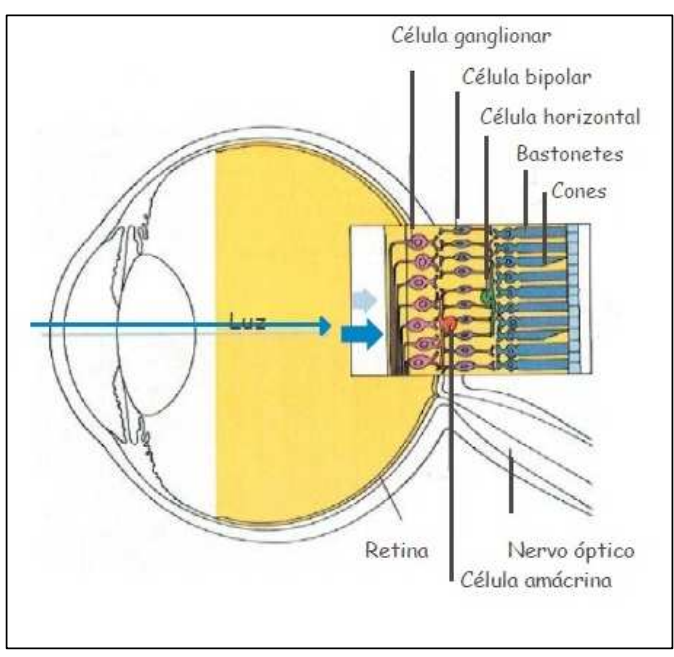

Figura 5 - A captação da luz na retina. Fonte: www.ibb.unesp.br/.../magens/retina1.jpg.

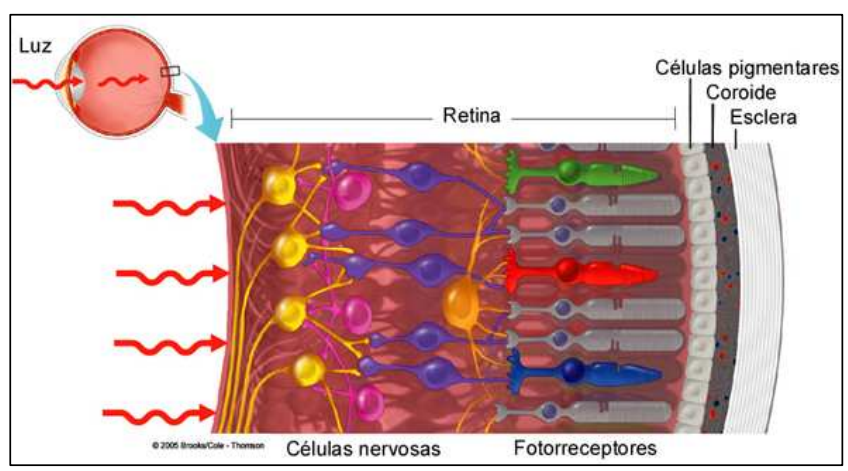

Figura 6 - A Retina.

Fonte: www.anato.ufrj.brmaterialNeurolbro_06Visao.pdf.

O tecido neural possui células especializadas dispostas em camadas (Figuras 5 e 6). A luz captada pelos fotorreceptores distribuídos ao longo da superfície da retina, por meio de sinais, passa por uma rede complexa de células. Todos esses sinais, por meio de sinapses, convergem sobre as células ganglionares de onde partem os axônios. O conjunto de todos os axônios forma o nervo óptico, que é o responsável por encaminhar ao cérebro os sinais (HUBEL, 1995).

Os fotorreceptores, como são denominados, são os receptores sensíveis à luz da retina e são de dois tipos, os cones e os bastonetes (WEITEN, 2002). Os bastonetes são muito mais numerosos que os cones e são, os fotorreceptores visuais, responsáveis pela visão noturna e periférica, pois são mais sensíveis à luz fraca; conforme aponta Hubel (1995). Ao contrário, os cones, em menor número, são os fotorreceptores, responsáveis pela visão diurna e pela visão das cores. 
A distribuição dos cones e bastonetes não é homogênea; os bastonetes predominam, na região periférica e vão diminuindo em direção ao centro, já os cones vão se intensificando, no centro da retina, atingindo a concentração máxima na região denominada fóvea central, região em que a luz captada, pela lente, incide e onde a acuidade visual é maior (HUBEL, 1995). Segundo Weiten (2002), a visão na fóvea é muito mais penetrante restando às demais regiões circundantes da retina a função de dar um aspecto geral do campo de visão.

No processo visual, após a recepção dos estímulos pelos fotorreceptores, se desencadeia um processo de sinais neurais, que passa pelas células bipolares e ganglionares que, por sua vez, enviam impulsos através do nervo ótico, e o nervo óptico de cada olho projeta informação para o cérebro. No cérebro, especificamente no córtex cerebral, que ocorre o processamento, como, por exemplo, a codificação das informações de cor, forma, contraste, profundidade e brilho, entre outros.

\subsubsection{O Córtex Cerebral}

A complexidade do sistema de codificação levou alguns cientistas a se dedicarem por décadas à compreensão da problemática de como as células corticais respondem aos estímulos gerados por uma fonte do estímulo visual, ou seja, a luz. Hubel e Wiesel (1995) identificaram a existência de três principais células visuais no córtex; eles constataram também que as células respondem melhor a sistemas mais complexos, como linhas e bordas, de que a estímulos mais simples, pontuais e pequenos. Entretanto, a grande descoberta desses pesquisadores está, no conhecimento de que as células no córtex cerebral são altamente especializadas, em outras palavras, são detectores de características, como assinala Weiten (2002, p.100): "[...] neurônios que respondem seletivamente a características muito específicas de estímulos mais complexos".

O cérebro recebe informação visual codificada através de impulsos nervosos, mas é, no córtex, que essas informações são processadas. Portanto, como Weiten afirma (2002, p. 99): "A luz incide sobre o olho, mas enxergamos com o cérebro", pois mesmo sendo a retina responsável pela grande parte do processamento, esse impulso visual não tem significado ${ }_{2}$ até que seja processado pelo cérebro. 
Um dado importante aqui apresentado é o significado. Pois, conforme apontam os estudos da psicologia ambiental, todos os dados absorvidos através dos órgãos sensoriais são prontamente codificados, comparados e traduzidos em ações, as quais são consequências dos significados impressos por cada pessoa nesse processo perceptivo, e muitas variantes e condicionantes definem o comportamento final (CASTELNOU, 2003; OKAMOTO, 1996).

O entendimento do funcionamento do sistema visual é de relevância para o assunto estudado, que consiste em compreender dois aspectos. Por um lado, a formação da cor, e, por outro lado, sua percepção e utilização, de forma adequada, no ambiente hospitalar. O uso adequado das cores ainda depende da compreensão da dinâmica da percepção psicológica das cores e dos significados atribuídos a elas, assuntos que serão discutidos no Capítulo Quatro.

Um hospital possibilita uma nova experiência de vida, podendo ser positiva ou negativa conforme a leitura desse espaço e encerra em si uma oportunidade única de reformulação pessoal (COSTA, 2001). E a arquitetura e seus elementos irão ser protagonistas dessa experiência.

Neste capítulo, foram apresentados, os principais elementos envolvidos, na visão das cores, além da abordagem das diferenças entre sensação e percepção das cores, assunto esse que permeia a maioria dos estudos sobre as aplicações das cores, na arquitetura, principalmente, no ambiente hospitalar, onde tal abordagem se faz ainda mais importante, pois a interação dos usuários com o ambiente se dá sob uma condição especial, emocional e psicológica, que influem diretamente na percepção desse espaço. 
CAPÍTULO 3

PRINCÍPIOS PARA O ESTUDO DAS CORES 


\section{CAPÍTULO 3 PRINCÍPIOS PARA O ESTUDO DAS CORES}

\subsection{TEORIA DAS CORES}

Alguns consideram que a primeira abordagem científica sobre o fenômeno cromático se deve a Isaac Newton, físico Inglês do séc.17. Após observar por meio de prismas o fenômeno da dispersão da luz do sol, Newton propôs que a luz branca conteria todos os comprimentos de onda do espectro visível.

A experiência de Newton consistiu na divisão da luz branca com um prisma e, posteriormente, a recombinação a luz com um segundo prisma, obtendo o branco novamente; no primeiro prisma, a luz branca é decomposta em segmentos coloridos, conforme é demonstrado na figura 7. Essas descobertas conduziram ao reconhecimento de que a luz é composta de uma mistura contínua de comprimentos de onda diferentes.

Para Newton (apud CÉSAR, 2003, p. 33), "[...] as cores são propriedades originais e inatas que diferem em raios diferentes". Sua Teoria está expressa, na obra Óptica, em que estabeleceu critérios para a produção da cor enquanto fenômeno físico. Suas maiores contribuições foram os estudos sobre refração, dispersão e reflexão da luz. Segundo César (2003), Newton foi o primeiro a elaborar um círculo cromático que serviu de base para outros inúmeros estudos posteriores. Newton inovou ao propor um sistema circular das cores, ao invés do sistema linear. Seu círculo cromático era composto pelas sete cores decompostas pela luz branca, são elas: vermelho $(p)$, laranja $(q)$, amarelo $(r)$, verde $(s)$, ciano $(t)$, ultramarine $(v)$, violeta $(x)$. E, no centro, a luz branca (Figura 8).

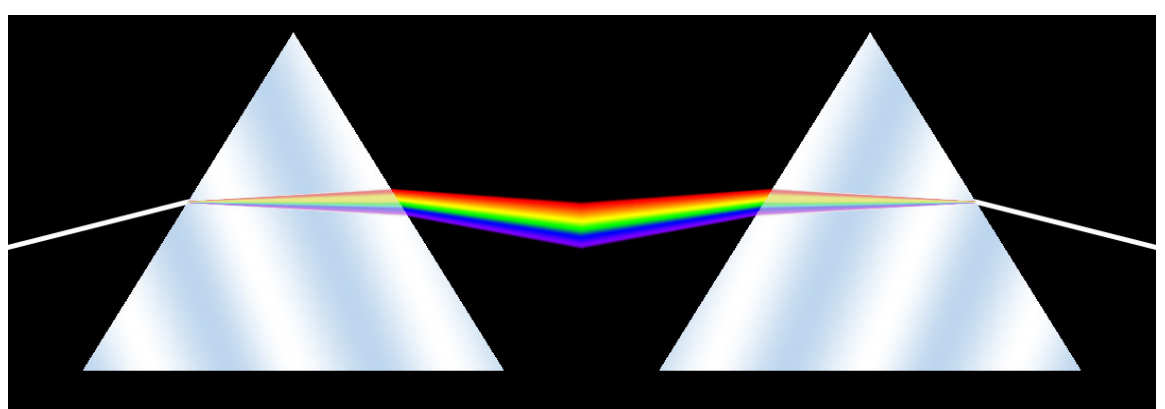

Figura 7 - Representação da experiência de Newton. Fonte: www.anasofia.net/pdf/linguagem_visual_grafica_03.pdf.

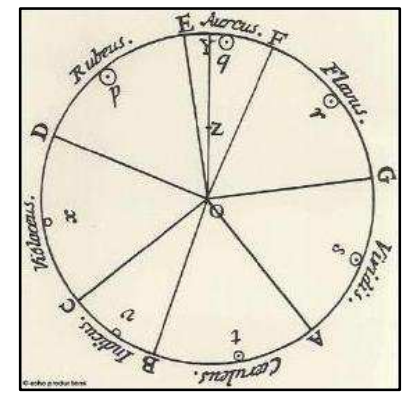

Figura 8 - Círculo Cromático. Fonte: www.colorsystem.com. 
Durante o século XVIII, chegou a ser percebido que qualquer cor poderia ser obtida por misturas de luz, de três comprimentos de onda diferentes, nas proporções certas. Weiten (2002) aponta que a base dessa descoberta é a Teoria Tricromática da visão das cores, promulgada pelo fisiologista inglês, Thomas Young, em 1802; segundo ele, a percepção de cores começa, nos olhos, com a captação tripla da luz, isto é, a captação por três células, distintas, foto-sensoras, uma para cada cor primária e que, segundo Hubel (1995), são: vermelho, verde e azul.

Os três cones, fotorreceptores, são os responsáveis pela captação de três diferentes comprimentos de onda. Segundo a Teoria de Young, a mescla das cores primárias gera a cor branca, o mesmo ocorre para outras mesclas, como é o caso do amarelo obtido pela mescla do verde e vermelho. Esse processo, em que duas luzes mescladas se convertem em uma cor secundária, é conhecido como mistura aditiva.

Conforme aponta a literatura, a Teoria de Thomas Young foi divulgada, desenvolvida e modificada pelo fisiologista alemão, Hermann von Helmholtz. As contribuições de Helmholtz à Teoria de Young foram essenciais, ao ponto de passar a ser conhecida como a Teoria de Young-Helmholtz.

Nos tempos modernos, a Teoria tricromática, que a cor depende de três tipos de detectores diferentes, foi confirmada em 1959, por dois grupos de estudo, formados segundo Weiten (2002) por, George Wald e Paul Brown de Harvard e, William Marks, William Dobelle, e Edward MacNichol de Johns Hopkins. Segundo Hubel (1995), foi através de análises microscópicas que se comprovou que existem três cones para absorver a luz, e que detectam a luz de comprimentos de onda diferentes.

Os três tipos de células fotorreceptoras das cores têm seu pico de absorção nos espectros de 420, 534, e 564 nanômetros como mostrados na figura 9 (MARIZ, 2009); a cada um dos cones relacionou-se a uma cor, àquela que representa o pico de absorção: azul, verde, e vermelho respectivamente; entretanto, segundo Dr. Hubel (1995, p. 5, tradução nossa):

[...] os nomes recorrem ao pico de sensibilidade [...] e não a forma como os pigmentos se parecem se estivéssemos a olhar para eles, luzes monocromáticas correspondentes a esses comprimentos de onda não são azuis, verdes, e vermelhas, mas sim, violeta, verde, e amarelo-limão [...]. 


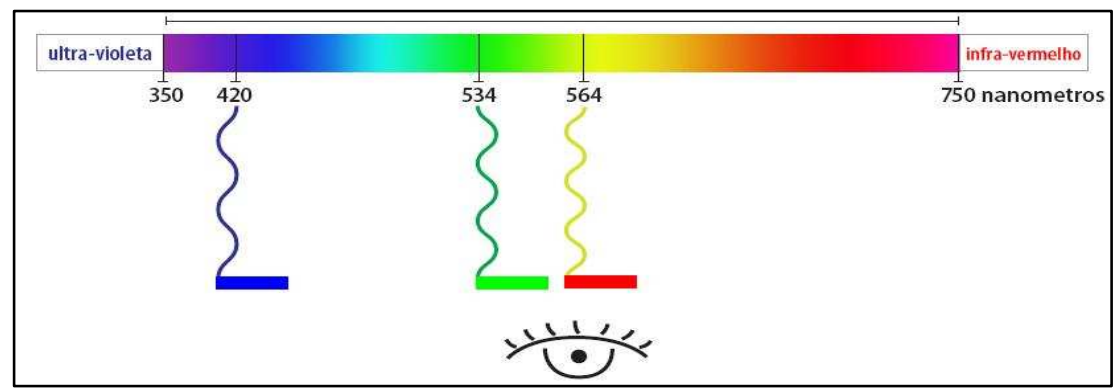

Figura 9 - Sensibilidade dos cones do olho humano. Fonte: www.anasofia.net/pdf/linguagem_visual_grafica_03.pdf.

Apesar de muitas características da visão das cores serem explicadas por essa teoria, Weiten (2002) conclui que algumas não são como é o caso das imagens posteriores complementares; esse fenômeno ocorre, quando, após fixar o olhar em uma determinada cor, por alguns instantes, e, logo em seguida se olhar para um fundo branco ou cinza, surge uma imagem posterior; uma imagem visual que persiste, mesmo depois, que o estímulo foi removido, essa imagem terá a cor complementar à cor vista originalmente (BERNS, 2000); segundo Hubel (1995), essa carência de explicação foi o ponto de partida para a elaboração de outra teoria sobre a visão das cores.

Ewald Hering, fisiologista alemão do séc. XIX, propôs a Teoria das Cores Oponentes, a qual consiste, na existência de três variedades de cones com dupla ação, ou seja, o sistema visual gera sinais em pares, adversários; para vermelhoverde, amarelo-azul, e preto-branco (Figura 10). Por meio de sua Teoria, Hering considerava ser essa a única forma de explicar o fato de que verde e vermelho não fazem parte de uma mesma cor ou serem igualmente descritas, o mesmo ocorre com o amarelo-azulado e verde-avermelhado, conforme assinala Weiten (2002).

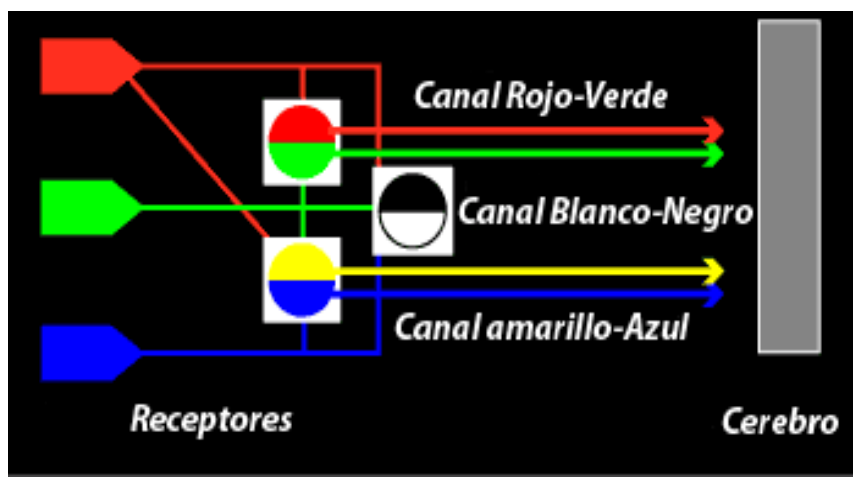

Figura 10 - Representação da Teoria de Hering. Fonte: www.campusvirtual.unex.es. 
Sua Teoria foi, por muito tempo, considerada como rival e contrária à Teoria de Young; Hubel (1995) salienta que ambas as proposições estavam certas, no séc. XX cientistas provaram tais constatações. O que os estudos recentes mostram é que, no início do processo da percepção das cores, a Teoria Tricromática está correta, servindo de base, enquanto a Teoria das Cores Oponentes embasa os estágios posteriores do processo visual (WEITEN, 2002). Assim, Hubel (1995) esclarece que, claramente, as duas formulações não são mutuamente exclusivas: ambos propõem um sistema de três-variáveis.

No entanto, mesmo Hubel esclarecendo que as duas Teorias são complementares ao processo de percepção visual, Weiten (2002) constata que nem sempre são consideradas complementares (2002, p. 104): "[...] os físicos geralmente apoiam a Teoria de Young, em oposição aos psicólogos que apoiam, frequentemente, a Teoria de Hering [...]".

As Teorias apresentadas ilustram o tema, possibilitando a compreensão dos fenômenos da mistura de cores, da constância de cores, entre outros. A combinação entre os estudos da psicofísica e os métodos de neurofisiologia, atualmente, complementam os conceitos promulgados nas Teorias.

No passado, o estudo das cores ultrapassou os limites das ciências exatas, e invadiu o campo das ciências humanas, como a filosofia. O estudo da percepção da cor incluiu poetas, como Goethe. João César (2003) levanta a Teoria das Cores de Goethe, ressaltando sua importância para o estudo do fenômeno cromático, por oferecer uma visão abrangente que envolve todo o processo de formação da cor. $\mathrm{Na}$ literatura sobre o tema, é possível encontrar várias citações sobre o fato, que a Teoria de Goethe, aliada à Teoria de Newton formam os principais conceitos sobre o tema.

Goethe, poeta alemão, entre o séc. XVIII e XIX, desenvolve sua Teoria em seu celebre livro, Doutrina das Cores. César (2003) menciona que, em uma visão filosófica, Goethe relaciona o homem com o mundo. Ele ainda salienta que o foco dos estudos sobre as cores de Goethe é no sensorial, ou seja, na sensação provocada pela cor na visão, o importante era compreender o fenômeno em sua 
totalidade; como o olho processava as imagens coloridas e como isso afetava os sentimentos.

Com relação à Teoria de Goethe, Lillian Barros (2009, p. 269) considera que sua importância reside, no fato de os horizontes do estudo cromático terem sido ampliados:

[...] a investigação de Goethe abriu novas portas para o conhecimento das cores, sugerindo um espectro multidisciplinar para diversas abordagens sobre o fenômeno [...] sua investigação revelou um horizonte muito mais amplo do fenômeno cromático, ligando-o a diversas áreas do conhecimento.

Até então, os estudos sobre as cores restringiam-se ao campo da física, com as concepções de Newton, considerando a cor uma particularidade da luz. A crença de Goethe, no poder das cores, o fez buscar fenômenos sensíveis e psicológicos, envolvidos e relacionados a ela, ao contrário do "[...] cientificismo matemático de Newton" (BAVARESCO, 2009, p.1). A nova abordagem desenvolvida por Goethe influenciou várias teorias da percepção, como é o caso da fenomenologia da visão, e segundo Barros (2009), principalmente, por evocar as relações perceptivas do observador com o fenômeno cromático, pois na Teoria de Goethe, o homem participa de forma ativa no processo de percepção da cor. César (2003, p. 46) complementa:

\footnotetext{
As mais importantes contribuições que a parte didática da obra de Goethe contém tornam-se a base da teoria da percepção visual que foram os textos clássicos das experiências praticadas pela Bauhaus de Walter Gropius pelos artistas mais ligados à cor como: Johannes Itten, Josef Albers, Wassily Kandisky e Paul Klee [...].
}

Em Doutrina das Cores, Goethe estabelece que a luz possui relação direta com a cor, sendo essa percebida posteriormente à percepção da luz; as cores são estimuladas junto à luz e não derivadas dela. O discípulo de Goethe, Schopenhauer (2003), faz uma colocação reflexiva: "[...] luz e cores são fenômenos de consciência (sensação e percepção) cujas condições são ocorrências fisiológicas, na retina e, no sistema nervoso, sendo provocadas por processos físicos” (GOETHE, 1993, p.18). É possível notar uma descrição próxima ao que os cientistas posteriormente descobriram sobre o processamento da cor e do sistema visual. 
O círculo cromático desenvolvido por Goethe (Figura 11), representa sua teoria, estando as cores relacionadas a adjetivos (BARROS, 2009), o qual para Caivano (1995a), representa a mescla de pigmentos; ao contrário do círculo cromático formulado por Newton, que corresponde à mescla de luzes.

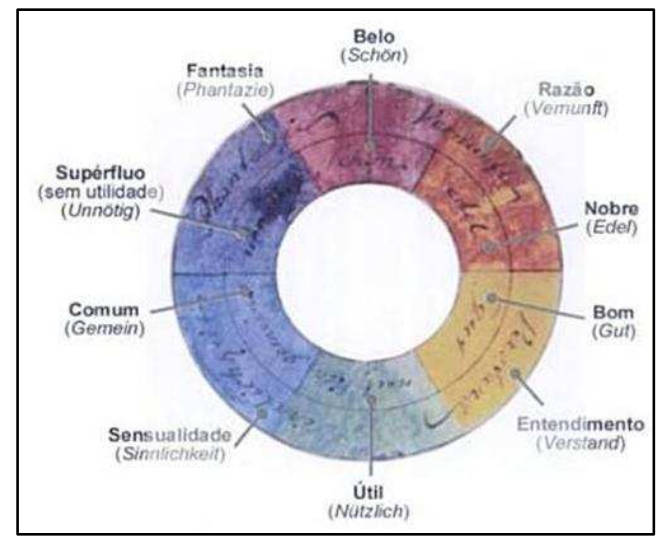

Figura 11 - Rosa dos Temperamentos. Círculo cromático de Goethe. Fonte: BARROS, 2009.

Uma abordagem que se encontra em Goethe (1993) é a investigação das cores ao ar livre, em oposição à de Newton que o fez na câmara escura. Seus estudos buscaram respostas mais abrangentes e associações que aproximassem 0 fenômeno cromático ao órgão perceptivo (o olho) e, ao meio em que a cor se manifesta (a natureza).

Sua maior descoberta para o conhecimento das cores, entretanto, não estava lá fora, à luz do dia, mas no interior do próprio observador do fenômeno: a descoberta de que as leis da percepção cromática resultavam de uma interação entre a natureza externa e a natureza interna do homem. (BARROS, 2009, p. 275).

Em relação às divergências entre a Teoria de Goethe e a de Newton, verifica-se que Goethe não compreendia como as cores poderiam se unir e formar a luz branca, mas, principalmente, discordava quanto à preexistência das cores, como previa Newton (GOETHE, 1993). Para Nelson Bavaresco (2009, p. 2), Goethe mudou a lógica do círculo de cores de Newton, pois segundo ele, Newton dedicou-se, exclusivamente, ao estudo da própria luz, enquanto que Goethe "[...] seguiu a lógica do poeta e pensador, sensível aos fenômenos desta sobre a psique dos indivíduos".

Lílian Barros (2009, p. 297) completa ao expor que o estudo primordial de Goethe é sobre o órgão de captação da visão, o olho, como menciona: "[...] a percepção da cor pelo órgão da visão torna-se, portanto, o centro de seu interesse". Além da 
ênfase, em seus estudos, que faz ao significado das cores, como apresenta João Carlos (2003), ele estabelece uma conexão simbólica entre percepção, cor e emoção.

Ainda, no campo da filosofia, o estudo da visão das cores conquistou inúmeros filósofos, como é o caso de Locke, Descartes e Schopenhauer. Esse último dedicouse aos estudos da cor enquanto fenômeno fisiológico, e possuía uma postura de consonância com as defendidas por Goethe, entretanto, por inúmeras vezes, em sua teoria, é possível verificar discrepâncias entre elas (SCHOPENHAUER, 2003). Ele defende a teoria de Goethe quanto aos estímulos externos que geram a atividade da retina, e que são divididas em duas causas, cores químicas e cores físicas, aquelas meramente temporárias, que surgem de combinações especiais de luz com meios transparentes, e essas cores inerentes aos corpos.

Um estudo da Teoria das cores é a base de qualquer esboço que se pretenda fazer sobre a aplicação das cores na arquitetura, pois, engloba além das questões físicas, as filosóficas, relacionadas a elas. A ciência, a medicina, assim como outras áreas do conhecimento, possibilitaram, com seus avanços tecnológicos, aprofundar o estudo das cores, auxiliando arquitetos e designers a projetarem um ambiente cromático para o indivíduo.

\subsection{MISTURAS DAS CORES}

Os estímulos que causam as sensações cromáticas podem ser divididos em dois tipos de estudo diferentes: a síntese aditiva e a síntese subtrativa. Os dois tipos de mistura funcionam diferentemente e apresentam características próprias, suas características serão apresentadas abaixo.

O uso das cores, no ambiente hospitalar, está nas tintas, tecidos, objetos coloridos e, também, em composições de iluminação, inclusive com fontes coloridas. Uma vez que a mistura das cores, entre luzes e entre pigmentos, é diferenciada (Figura 12), seguindo, cada qual, um princípio e, resultando em combinações distintas, para aplicação prática das cores, no ambiente hospitalar, a abordagem desse tema, representa um componente básico; 


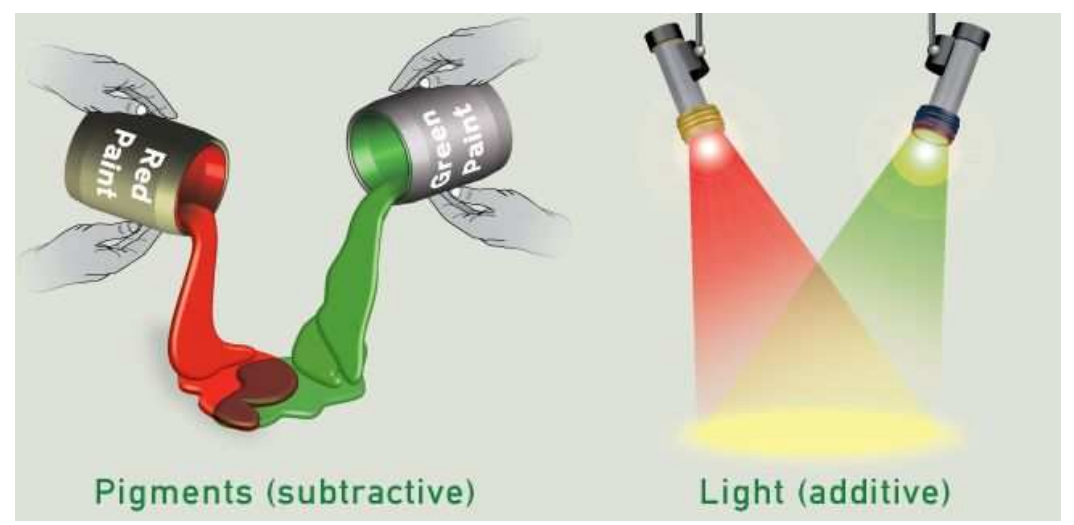

Figura 12 - llustração dos dois sistemas de mistura das cores - aditivo e subtrativo. Na síntese aditiva (à direita) é a luz o componente de mistura,

já na síntese subtrativa o pigmento é o componente da mistura (à esquerda). Fonte: www.webexhibits.org/causesofcolor/1BA.html.

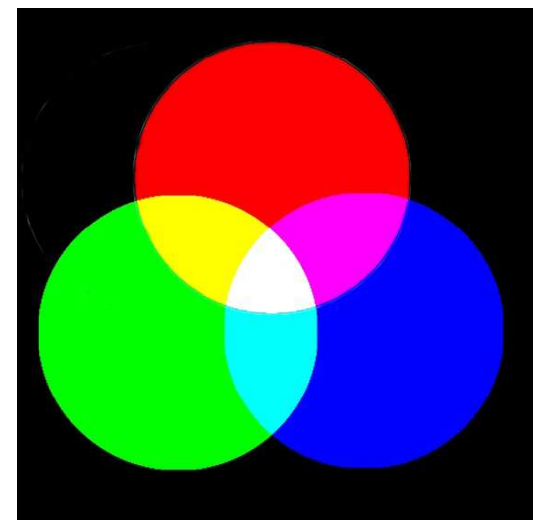

Figura 13 - Síntese Aditiva. Fonte: GUIMARÃES, 2003.

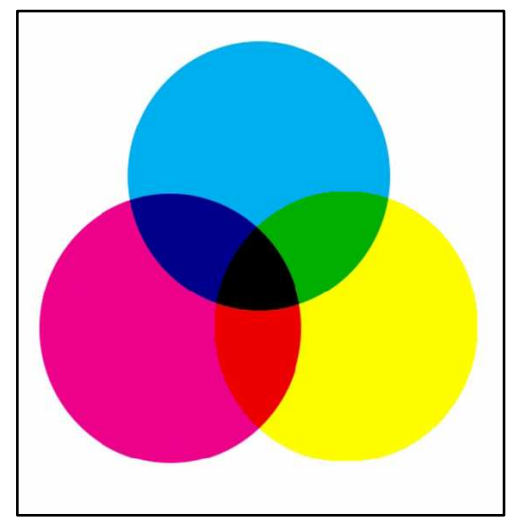

Figura 14 - Síntese Subtrativa. Fonte: GUIMARÃES, 2003.

\subsubsection{Cor-Luz}

O termo cor-luz é usado para definir a formação de cor a partir da emissão de uma fonte luminosa, que pode ser o sol, uma vela ou uma lâmpada. A mistura dessas cores é denominada síntese aditiva (Figura 13). Pedrosa (1980) afirma que a melhor expressão desse tipo de síntese é a luz solar, pois, sua composição é de faixas coloridas que quando isoladas, uma a uma, representam luzes monocromáticas.

As cores primárias da síntese aditiva são: o vermelho (R-red), o verde (G-green) e o azul (B-blue), sistema denominado RGB, que designa as cores projetadas, nos computadores e televisores. A mistura das cores primárias resulta na luz branca, e a mistura entre elas resulta nas demais cores (Figura 13). A mistura de duas cores primárias resulta em cores secundárias, essas, por sua vez, correspondem às primárias da síntese subtrativa, como mostra a figura 14. 
Segundo Pedrosa (1980), esse estímulo é mais estudado na física, e apresenta vasto emprego na sociedade contemporânea, inclusive no ambiente hospitalar, que, há alguns anos, incorpora esse tipo de estímulo ao ambiente.

\subsubsection{Cor-Pigmento}

O termo cor-pigmento denomina a mistura de cor por reflexão e absorção de luz de um objeto iluminado, em outras palavras, quando uma fonte luminosa recai sobre um objeto, parte é absorvida e parte refletida, e de acordo com Pedrosa (1980), dependendo da composição química do objeto, será refletida uma determinada cor.

Essa síntese é denominada subtrativa, e ao contrário do que ocorre na síntese aditiva, a mistura das três cores primárias dessa síntese resulta no preto, sendo as cores primárias: o azul (C-cyan), o magenta (M) e o amarelo (Y-yellow) (Figura 14). Nos programas de computação gráfica, esse sistema é denominado CMYK; sendo a letra (K) a designação da cor preta (BlacK).

A mistura de duas dessas cores resulta em uma composição secundária que são: magenta e amarelo - vermelho, magenta e cyan - roxo e cyan e amarelo - verde. $O$ sistema das cores subtrativas é comumente usado para impressões e para as artes plásticas em geral (PEDROSA, 1980).

\subsection{ATRIBUTOS DAS CORES}

Dando continuidade ao estudo das cores, o item em questão define parâmetros para a descrição e classificação das cores. Os atributos são características da cor, pelos quais é possível estudá-las em termos mensuráveis, e são fundamentais para o estudo das leis de harmonia e composição de contrastes.

Os atributos desempenham papel determinante, no planejamento e projeto de composições cromáticas para um ambiente, funcionando como elementos compositivos, pois, mudanças de escalas, em qualquer um dos atributos, a cor percebida também será modificada, como Pedrosa (1980, p. 35) menciona: “[...] 
características correspondem às propriedades intrínsecas reveladas em cada cor, guardando certa relação perceptiva com os corpos em que elas se apresentam [...]".

Posteriormente, quando forem levantados os sistemas de notação cromática, 0 entendimento e conhecimento dos atributos das cores é essencial, pois são eles que compõem os espaços de cores, tornando capaz a ordenação e organização das mesmas.

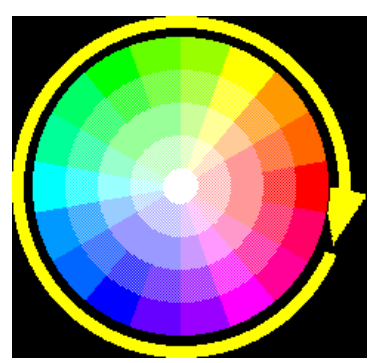

Figura 15 -. Matizes. Fonte: CÉSAR, 2007.

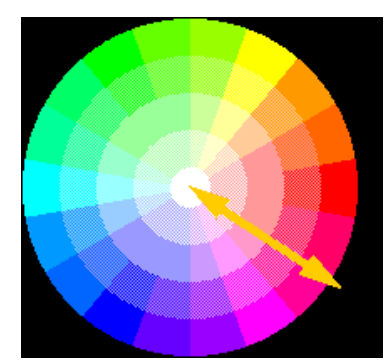

Figura 16 - Escala de saturação. Fonte: CÉSAR, 2007.

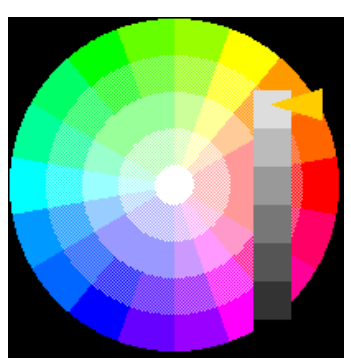

Figura 17 - Escala de luminosidade. Fonte: CÉSAR, 2007.

\subsubsection{Matiz/ Tom}

Para Lou Michel (1995), o matiz é o atributo que descreve a sensação de cor, na retina, e que difere uns de outros, como o vermelho e o verde (Figura 15). Pedrosa (1980) ressalta ainda o uso do termo tom, e até mesmo, da palavra cor substituindo o termo matiz; que para ele, refere-se à variedade de comprimento de onda de luz direta ou refletida.

\subsubsection{Saturação/ Croma}

A saturação pode ser definida como a quantidade que um determinado matiz possui, de tom cinza em relação ao preto e ao branco, tornando-a, desse modo, mais pura ou não; em outras palavras, refere-se à pureza percebida como intensidade da cor, segundo Berns (2000). Para Pedrosa (1980), é decorrente desse atributo que nascem as expressões verde-vivo ou verde-puro (Figura 16).

Para Caivano (1995a, p.14, tradução nossa): "O croma se refere ao aspecto que varia entre uma cor intensa ou de máxima pureza e um apagado ou acinzentado, supondo que pertençam ao mesmo matiz e possuam idêntico valor". 


\subsubsection{Luminosidade/ Valor}

Berns (2000) menciona que o atributo luminosidade pode ser entendido como a cor se parece mais ou menos luminosa, dependendo do quanto ela se aproxima do preto ou do branco (Figura 17).

Com o foco da aplicação da cores, no ambiente hospitalar e, considerando a composição da paleta cromática elemento fundamental, o estudo dos atributos das cores é condição sine qua non, pois guia a utilização das cores na arquitetura. No ambiente hospitalar, a escolha dos matizes e, principalmente, das escalas de saturação, são os principais elementos a serem considerados e avaliados, sendo determinantes para a composição cromática, tendo em vista objetivos, como gerar sentimento de bem-estar e suporte psicológico aos pacientes, promover a eficiência e a produtividade das equipes e, aumentar a ergonomia visual.

\subsection{SISTEMAS DE NOTAÇÃO CROMÁTICA}

Com o embasamento dos atributos das cores, levantados no item acima, é possível ordená-las, tornando possível mensurá-las, e descrevê-las, e consequentemente reproduzi-las. Assim, os sistemas de notação cromática constituem-se ferramenta de trabalho para designers e arquitetos.

Desde os mais antigos estudos sobre a cor, a ideia de organizá-la, seguindo alguma lógica, foi uma constante, e apresenta, desde a antiguidade, vários exemplares. Aristóteles (384-322 AC), Leonardo Da Vinci (1490-1516), Newton (1704) e Goethe (1808) todos se dedicaram a, de alguma forma, ordenar as cores sob uma lógica. No entanto, foi, nos séculos XIX e XX, que houve realmente uma evolução quanto aos sistemas de notação cromática.

Estudiosos, cientistas e artistas se dedicaram à formulação de sistemas de ordenação das cores, dentre eles se sobressaem os estudos de Ostwald (1917) e Henri Munsell (1905). Também algumas instituições se dedicaram aos estudos de sistemas de notação cromática, é o caso da CIE -Commission Internacionale de l'Eclairage (Comissão Internacional de lluminação) e Swedish Standards Institution. 
Um sistema de ordenação de cores, como esclarece Caivano (1995a), tem por fundamento transformar um estudo teórico em um modelo geométrico, ou seja, estabelecer relações de localização e valores, em modelos tridimensionais. Nos modelos, as cores apresentam uma disposição específica, assim como, cada um de seus componentes, em uma organização final lógica. Os sistemas desenvolvidos variam de forma, existindo os lineares, os círculos cromáticos e os triângulos de cores.

Os modelos tridimensionais, além dos matizes descritos, no círculo cromático, contam ainda com as variantes, saturação e luminosidade. Conforme o sistema de notação, os nomes para os atributos podem variar, da mesma forma, a corrente filosófica e científica em que se baseiam; e ainda, uns se referem à cor-luz, enquanto outros, à cor-pigmento. Alguns sistemas de notação cromática serão mencionados, optou-se por levantar aqueles que, de alguma maneira, se destacaram ou se relacionam, mais estritamente, ao tema da dissertação.

A aplicação dos sistemas de organização se destina aos diferentes usos das cores, para um programa gráfico, um artista, um pintor ou para a arquitetura, levando-se em consideração que cada sistema se aplica de forma mais apropriada para determinado fim. Tais considerações podem ser vistas, no parágrafo abaixo, de José Luis Caivano (1995a, p. 3, tradução nossa):

[...] do ponto de vista do estímulo luminoso as cores primárias estarão dadas por luzes monocromáticas vermelha, verde e azul, e se um pergunta a um colorimetrista, a um iluminador ou a um técnico em televisor, a resposta será que estas são as cores primárias. Para os pintores, acostumados a trabalhar com pigmentos e mediante mesclas subtrativas, as cores primárias tem sido tradicionalmente o amarelo, vermelho e azul, enquanto que as secundárias obtidas por mesclas de duas primárias, 0 laranja, o verde e o violeta. Para um sistema cuja utilidade está dirigida à indústria gráfica as cores primárias serão o amarelo, magenta e o cian. Para os sistemas que consideram a cor como sensação psicológica, as primárias estarão dadas pelas noções primitivas acerca da cor que se encontram na base de todas as culturas, e então serão - organizados geralmente de pares em pólos opostos - o vermelho e o verde, o amarelo e o azul, e o branco e o preto. 


\subsubsection{Duplo Cone de Wilhelm Ostwald}

Em 1909, Wilhelm Ostwald (1853-1932), prêmio Nobel de Química, começou a desenvolver um sistema de ordenação de cores com base na percepção, assim como fez o pintor americano Henry Munsell, o qual Ostwald havia conhecido e que Ihe serviu de influência (KOPACZ, 2003). O sistema de Ostwald é considerado por Caivano (1995a) como uma das primeiras organizações de cor, importante, do século XX.

O sistema de organização de Ostwald é desenvolvido em função de variáveis de conteúdo de matiz, de branco e de preto, ou seja, quanto corresponde à proporção de cada um desses componentes na sensação da cor percebida (KOPACZ, 2003). Seu estudo parte do círculo cromático, o qual, conforme proposto por Ostwald, apresenta 24 matizes diferentes, a esses matizes já estão incorporadas as quatro cores elementares, que são: o amarelo, o vermelho, o azul e o verde, os quais dividem o círculo em 4 segmentos iguais. Os matizes que compõem o círculo cromático são aqueles, cujo grau de pureza é o máximo obtido, e estão dispostas de forma a ficarem diametralmente com suas cores opostas (Figura 18).

Pelo centro do círculo cromático, passa um eixo com uma escala de cinza, do branco ao preto, na parte superior e inferior, respectivamente; essa escala é composta por oito gradações, sendo as nomenclaturas as letras do alfabeto: a (branco), c, e, g, i, l, n, p (preto), como pode ser visto na figura 18.
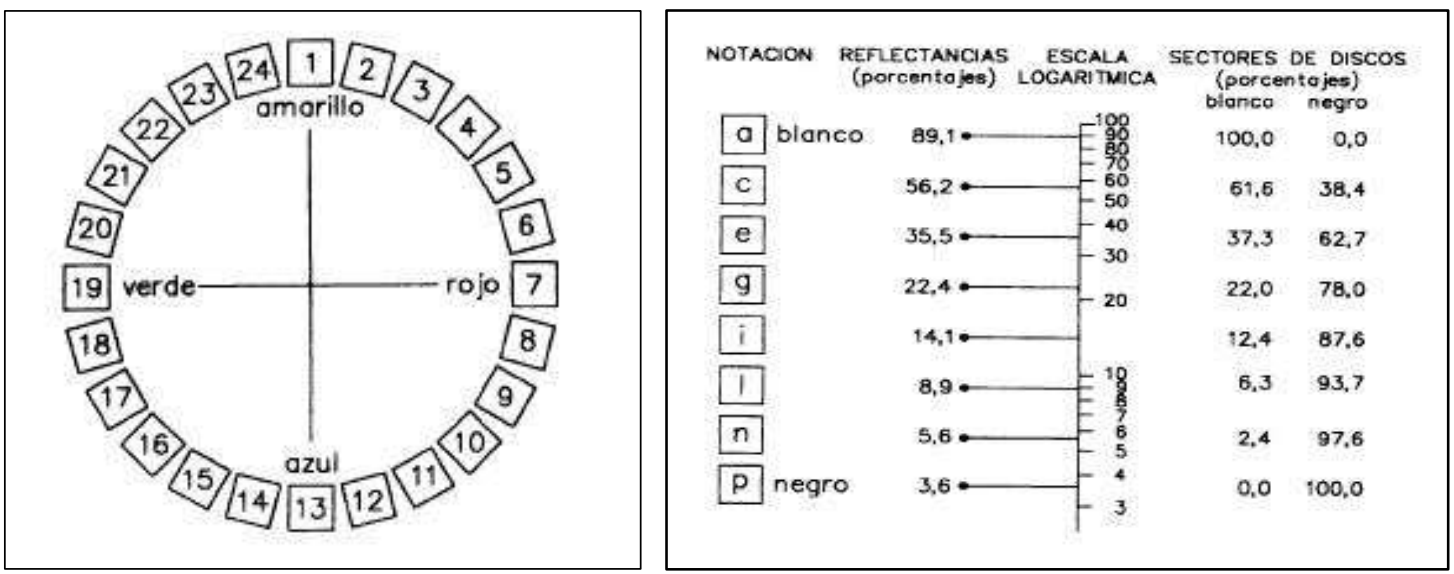

Figura 18 - Relações dos atributos no Sistema Ostwald.

À esquerda Círculo Cromático. À direita: escala de cinzas e as relações logarítmicas.

Fonte: CAIVANO, 1995a. 
Conforma Caivano menciona (1995a), a escala das cores acromáticas (cinza) obedece a uma sequência geométrica e é regida pelas leis da psicofísica de Weberfechner, a qual está relacionada aos logaritmos.

Para cada matiz do círculo cromático, há uma escala de proporções diferentes de preto e branco; essas variações formam um triângulo equilátero (Figura 19), mostrando todas as proporções possíveis. A junção dos triângulos, de todos os matizes, forma um modelo tridimensional de duplo cone, formando o sistema sólido de Ostwald (Figura 20).

O Atlas das cores de Ostwald foi publicado originalmente, em 1917, mas, atualmente seu sistema não apresenta aplicação prática, entretanto, conforme Caivano (1995a) afirma, a importância do sistema de Ostwald está sob o ponto de vista histórico, tendo influenciado o movimento De Stijl, o qual teve Piet Mondrian, no centro dos trabalhos. O tratamento de Mondrian em relação às cores, no período entre 1917 e 1918, tinha muito em comum com as teorias de Ostwald.

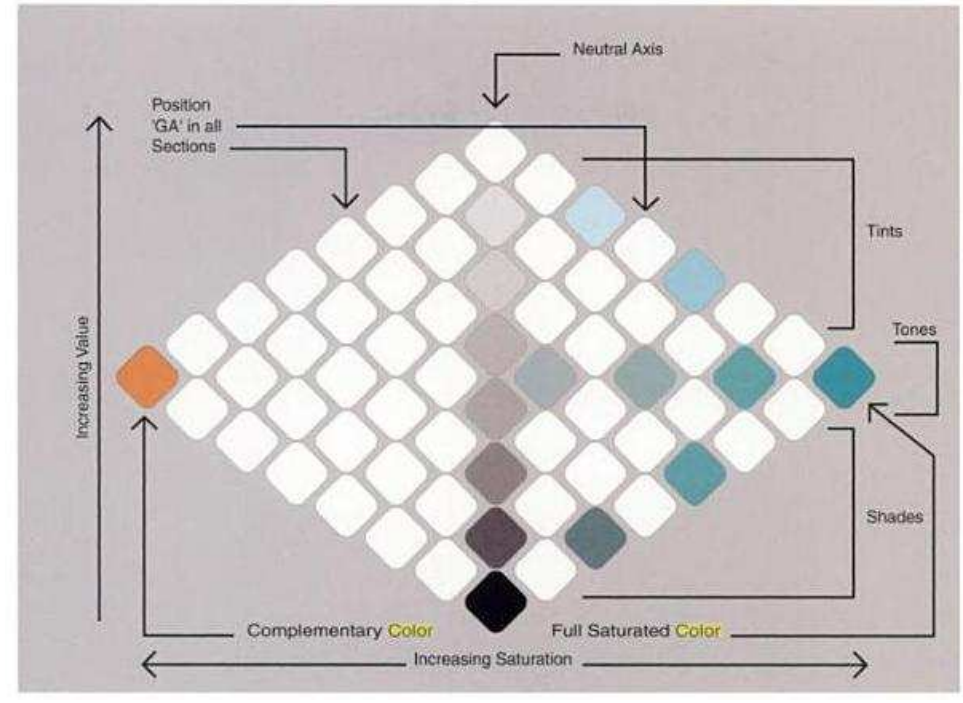

Figura 19 - Triângulo de Ostwald. A coluna central representa a escala de cinza, nos vértices, os matizes, na saturação máxima. Fonte: KOPACZ, 2003.

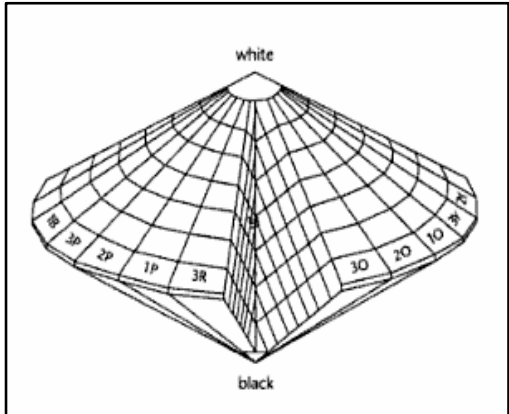

Figura 20 - Duplo Cone de Ostwald. Fonte: CAIVANO, 1995a.

\footnotetext{
${ }^{1}$ A Psicofísica é uma disciplina, dentro de psicologia, que investiga a relação entre estímulos físicos e sua relação subjetiva ou perceptiva, ou seja, entre o estímulo e a sensação, por meio de formulações matemáticas, e variadas técnicas de medições. Foi formulada em 1860, por Gustav Theodor Fechner ao publicar Elements of Psychophysics", onde apareceu pela primeira vez o termo psicofísica. Ele foi influenciado pelo trabalho do fisiologista alemão Ernst Heinrich Weber (GESCHEIDER, 1997).
} 


\subsection{2 Árvore de Munsell}

Artista Plástico americano, Albert Henry Munsell (1858-1918) é o responsável por desenvolver um sistema de ordenação de cores que é considerado, por muitos, como o mais bem sucedido. Seu estudo teve como objetivo fornecer amostras padronizadas dos nomes das cores, de acordo com um plano logicamente organizado, obtendo a sua descrição exata, permitindo discutir a cor cientificamente, além de auxiliar no ensino dessa.

O sistema de ordenação de cores de Munsell obteve reconhecimento internacional e serviu de base para a fundação de outros sistemas de notação cromática (CÉSAR, 2003). É o autor dos livros: A Color Notation (1905) e Atlas of the Munsell Color System (1915).

O sistema é baseado, no princípio de "equidistância percebida", ou seja, as cores do círculo cromático estão dispostas em distâncias aparentemente iguais. O círculo cromático de Munsell é fundamentado sobre cinco cores principiais, estabelecidas por ele, e são: o vermelho $(R)$, o amarelo $(Y)$, o verde $(G)$, o azul $(B)$ e o roxo $(P)$. Também compõem o círculo, mais cinco cores intermediárias, resultantes de misturas: amarelo-vermelho (YR), verde-amarelo (GY), azul-verde (BG), roxo-azul (PB) e vermelho-púrpura (RP), como mostra a figura 21; todas as cores do círculo constituem o atributo matiz (hue-H) do sistema Munsell, e que recebem, segundo Feisner (2006) arbitrariamente, o parâmetro croma (5).

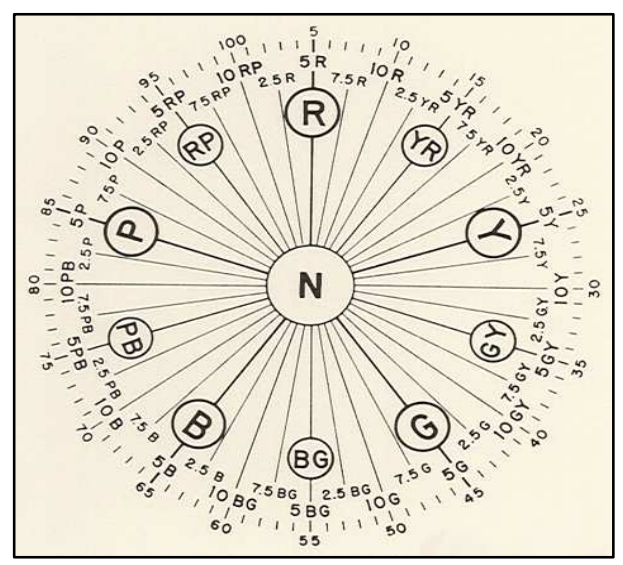

Figura 21 - Círculo cromático de Munsell. Fonte: www.colorsystem.com.

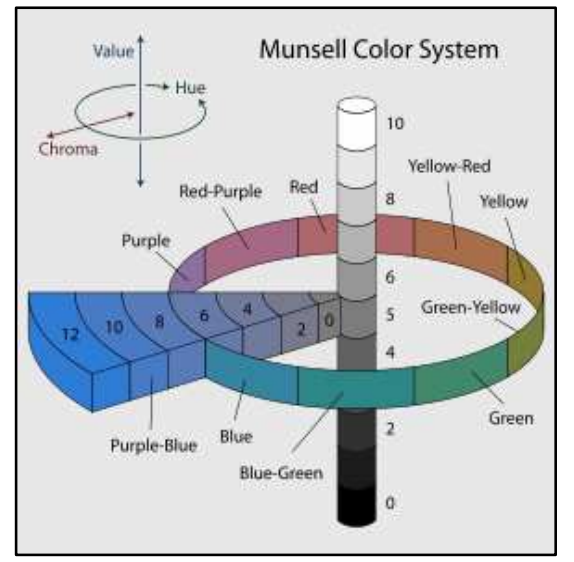

Figura 22 - Esquema dos eixos do sistema Munsell. Fonte: Munsell Color System. 
O círculo cromático está disposto ao redor de um eixo vertical denominado neutro (N). No pé do eixo, está o preto e, no topo, o branco, e, no intervalo entre eles, uma escala de cinza. O eixo neutro representa o atributo valor (value - V), ou índice de luminosidade, dessa forma, cada matiz apresenta uma intensidade de luminosidade. Em ordem de diferentes valores, a escala de saturação (chroma-C) está perpendicular ao eixo vertical (Figura 22), aumentando o grau de pureza ou saturação, para a extremidade externa, formando quase um triângulo (Figura 23).

A organização tridimensional das cores de Munsell é conhecida como "espaço de cores Munsell". O círculo cromático juntamente com os eixos propostos, por ele, constitui as relações entre as cores, organizado em uma árvore (figura 24), como é conhecido.

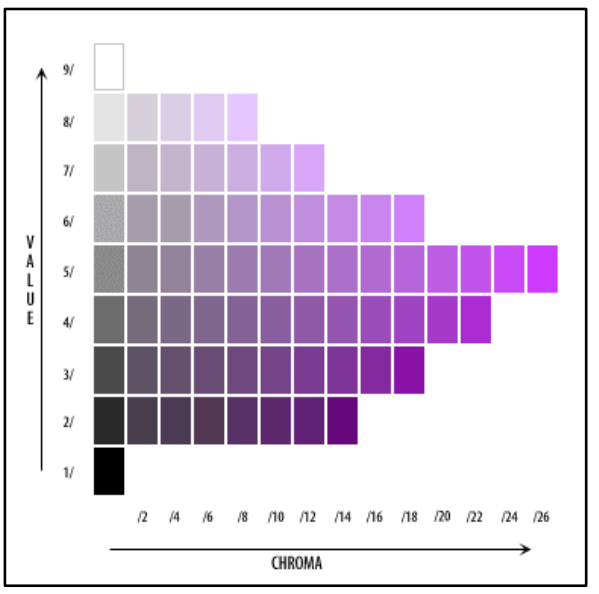

Figura 23 - A escala de luminosidade e saturação de um matiz. Fonte: Munsell Color System.

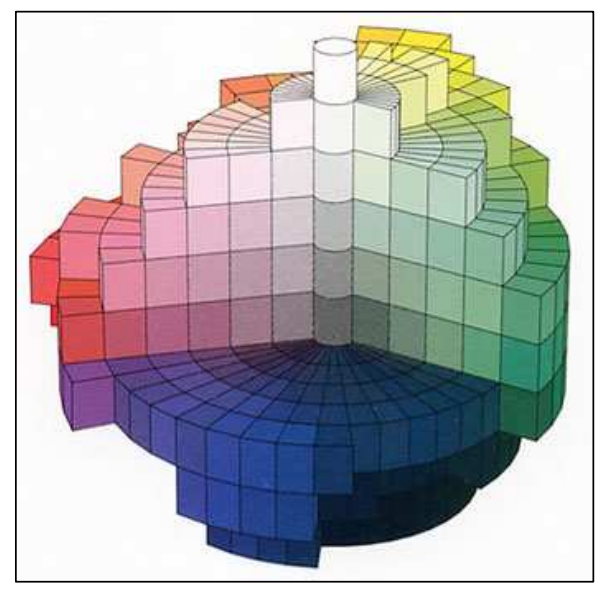

Figura 24 - Sólido das cores de Munsell. Fonte: Munsell Color System.

Para a notação de um matiz, no sistema Munsell, usam-se as nomenclaturas H - V $\mathrm{C}$, que representam respectivamente, matiz (hue), luminosidade (value) e saturação (chroma), um exemplo de notação Munsell é o matiz 5R 6/14, que representa uma cor vermelho-vivo, onde: $5 \mathrm{R}$ representa o matiz (vermelho), seis indica o valor da luminosidade (moderadamente clara) e o valor 14 indica a saturação, nesse caso, muito viva (COLOR SYSTEM).

O sistema Munsell possui um grande número de adeptos, algum dos países que se utilizam desse sistema como padrão tanto para a indústria como para outras aplicações, como as artes plásticas e arquitetura, são os Estados Unidos, Japão e Itália. 


\subsubsection{Espaço de Cores CIE 1931}

A necessidade de uma padronização de cores para a indústria e, a sua exata reprodução, e que todavia permitisse a perfeita medição e determinação das diferenças, fez com que, em 1931, sob o comando da Comissão Internacional de lluminação - CIE (Commission International de l'Eclairge), fosse explorado o tema. Tal investigação resultou em um sistema de ordenação de cores, o CIE. O sistema desenvolvido é baseado, na Teoria do tri-estímulo de percepção da cor, Feisner (2006) aclara que se refere ao fato de a retina ter três tipos de sensores para a captação das luzes (FEISNER, 2006).

O sistema consiste, na distribuição espectral da luz, tanto de fontes primárias como secundárias, ou seja, aquelas que emitem diretamente a fonte, e essas que refletem luz proveniente de outras fontes primárias. O diagrama CIE que é chamado de Triângulo, conforme aponta Fairchild (2005) é de fato uma curva, baseada na curva de luminosidade.

O diagrama é composto por três valores, os quais determinam a cromaticidade de uma cor, são eles: matiz, saturação e luminosidade. O diagrama de cromaticidade tem os matizes (comprimento de onda) espalhados por todo seu perímetro, já as mesclas dos matizes localizam-se no centro, chamado de (E) (Figura 25 e 26).

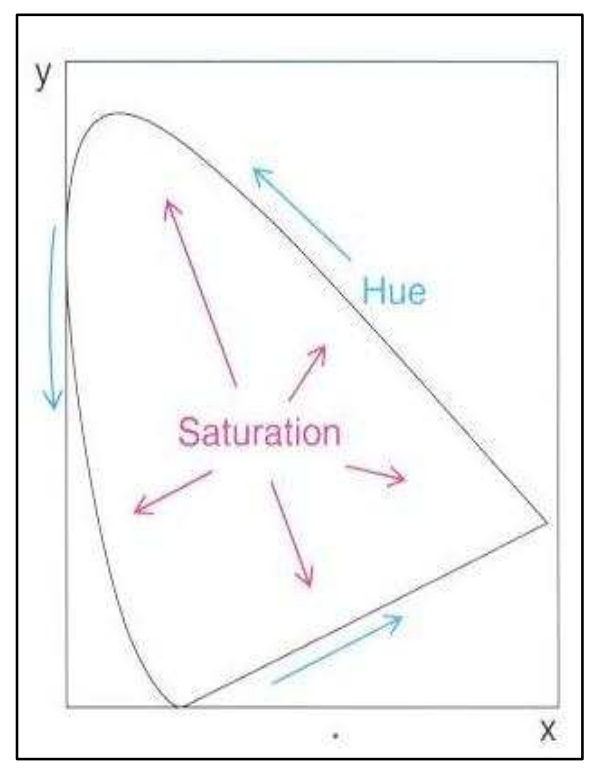

Figura 25 - Esquema do sistema CIE de 1931. Fonte: www.arq.ufsc.br/labcon.

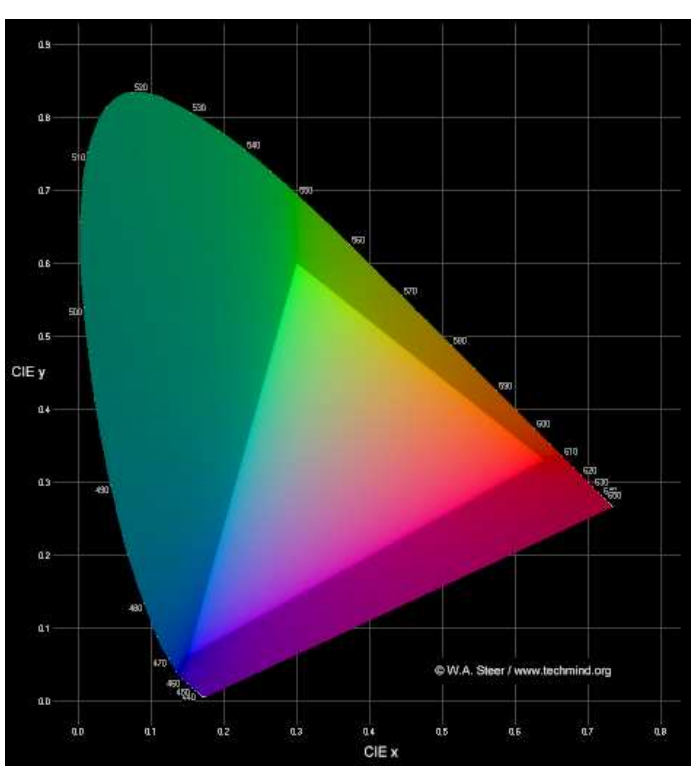

Figura 26 - Modelo CIE. Fonte: www.techmind.org/colour. 
Para as mesclas aditivas, o valor (E) é branco, enquanto para as mesclas subtrativas, o valor (E) é preto, ou uma mistura denominada de neutro escuro. As cores são expressas em valores tonais $X, Y$ e $Z$, como visto nas figuras 25 e 26. A partir do modelo original do CIE, foram, posteriormente, desenvolvidos outros dois sistemas para a definição das cores: o CIELUV e o CIELAB (CIE, 2010).

Segundo Kopacz (2003), o sistema CIE é difundido internacionalmente e muito utilizado em diversas áreas. O sistema utiliza-se dos principais atributos da cor matiz, saturação e luminosidade - para compor seu diagrama, Guimarães (2005) ressalta que diferentes siglas podem designá-lo:

HSV (Hue, Saturation, Value - matiz, saturação, valor);

HSB (Hue, Saturation, Brightness - matiz, saturação, brilho);

HSL (Hue, Saturation, Lightness - matiz, saturação, luminosidade).

\subsubsection{Sistema Natural das Cores NCS}

O sistema de notação cromática Natural Color System - NCS é relativamente recente, de 1985. Ele, como os outros, segue uma ordem lógica e designa a cada matiz uma única notação, e adotou aspectos dos sistemas de notação cromática de Munsell e de Ostwald. O Sistema NCS tem sua origem, na Suécia, com influências da Teoria de Ewald Hering (FAIRCHILD, 2005). O desenvolvimento do sistema foi liderado por Anders Hård, em cooperação com outros pesquisadores, o Dr. Lars Sivik e o Prof. Gunnar Tonnquist, estudiosos mundialmente conhecidos por suas pesquisas na área (NCS, 2010).

É um sistema baseado, na percepção, seguindo uma abordagem estritamente fenomenológica (NCS, 2010). Segundo Caivano (1995a), a cor percebida pode ser descrita, na quantificação de sua semelhança com as sensações provocadas pelas quatro cores primárias; o princípio da semelhança é um conceito que estabelece que cada cor seja semelhante a um máximo de duas cores primárias cromáticas.

O sistema trabalha com seis cores primárias, e que são percebidas pelos seres humanos como sendo "puras" (NCS, 2010). As quatro cores cromáticas elementares, que são baseadas nas de Leonardo da Vinci, segundo Caivano 
(1995a), são: o amarelo (Y), o vermelho (R), o azul (B) e o verde (G), e as duas cores acromáticas primárias são: o branco (W) e o preto (S).

As quatro cores primárias formam o círculo cromático; cada quadrante é dividido entre duas cores primárias, e entre elas há uma divisão de 10 segmentos, que configuram os outros matizes do círculo cromático, esses matizes secundários são determinados em função de quantidade que possuem das elementares, a quantidade é expressa em percentual, tais relações podem ser vistas na figura 27.

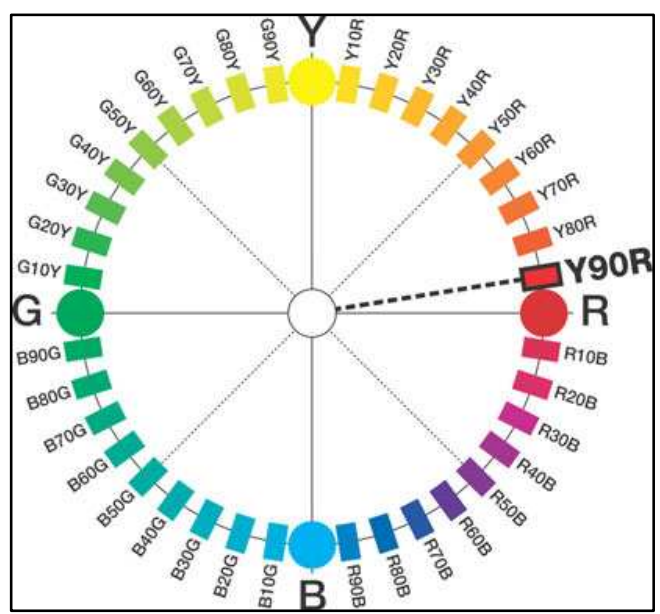

Figura 27 - Círculo Cromático NCS. Fonte: NCS.

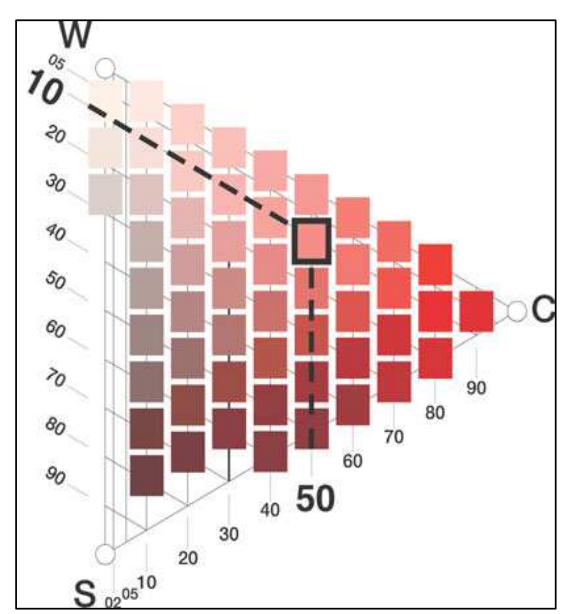

Figura 28 - Detalhe de uma notação NCS Fonte: NCS.

O círculo cromático está distribuído ao redor de um eixo que, compreendendo do branco ao preto, apresenta gradações de cinza (NCS, 2010). Por meio da ligação entre as duas extremidades das cores acromáticas, preto (S) e branco (W), e uma cor definida, no círculo cromático, obtém-se um triângulo (Figura 28), que é uma seção vertical do espaço de cores NCS (Figura 29). A base do triângulo formada pela escala de cinza, entre o branco (W) ao preto (S), e o vértice do triângulo corresponde à cromaticidade máxima $(C)$ de um matiz.

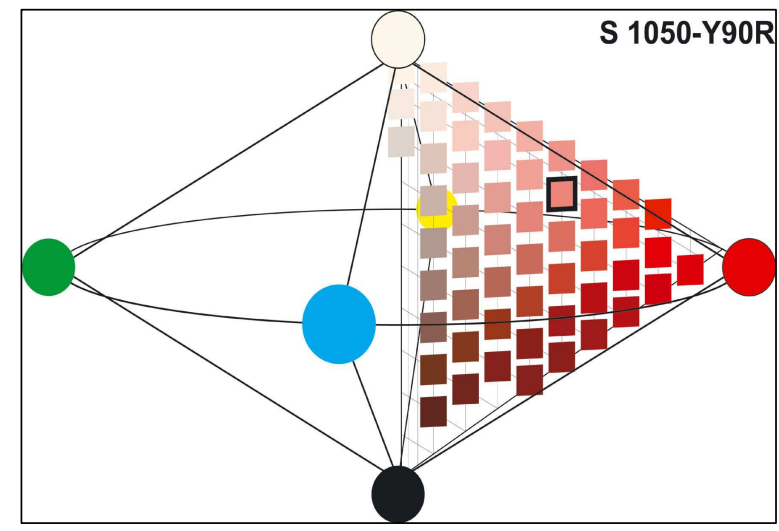

Figura 29 - Um matiz no Espaço de Cores NCS.

Fonte: NCS. 


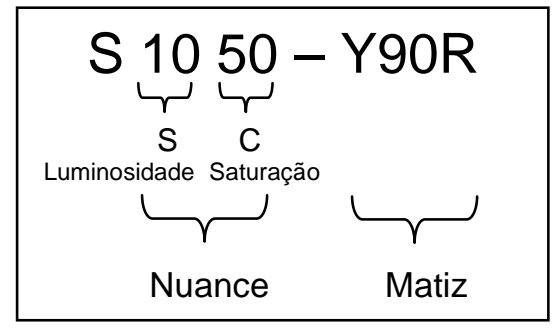

Figura 30 - Notação NCS de um matiz. Fonte: NCS.

Como exemplo da notação de um matiz, no sistema NCS, a figura acima representa a notação, NCS 1050-Y90R, e deve ser interpretada da seguinte forma: o valor 1050 descreve os nuances, ou seja, o grau de semelhança, com a brancura, que é de $40 \%$ e, negritude, que é de $10 \%$,sendo que a cromaticidade máxima é de $50 \%$. 0 Y90R descreve o matiz, ou seja, o grau de semelhança entre amarelos e vermelhos ( $\mathrm{Y}$ e R), assim Y90R representa um matiz que tem 10\% de amarelo e $90 \%$ de vermelho. A letra (S) anterior à notação NCS (S 1050 - Y90R) significa que a amostra é um padrão de cores NCS, emitido pela Scandinavian Colour Institute.

O sistema NCS possui ampla divulgação, principalmente, na Suécia e nos países escandinavos, e é usado como base para inúmeros tipos de aplicação das cores. No entanto, o sistema foi desenvolvido com uma aplicação mais direcionada à arquitetura.

\subsubsection{SCC: Um Sistema de Notação Cromática Brasileiro}

É um sistema de ordem das cores desenvolvido no Brasil. Seu desenvolvimento se deu pelo designer gráfico e artista plástico, Nelson Bavaresco, por volta de 1975. A pesquisa partiu da necessidade de se utilizar a cor com um maior conhecimento científico. O sistema desenvolvido por Bavaresco é influenciado pelos sistemas de Munsell, Ostwald e o NCS, além da teoria de Küppers. O primeiro modelo estrutural do sistema foi desenvolvido em 1994. O sistema SCC, como é conhecido, trabalha com um padrão CMYK em computador, devido a esse fato, suas cores podem ser especificadas em outros sistemas de notação como o RGB, HSB e LAB. O catálogo de cores é composto por 2.421 tonalidades (CECOR, 2010), sendo o círculo cromático formado por 24 matizes, igual ao sistema Munsell. Os matizes se desdobram em triângulos contendo cada um 100 pontos de cor. Na parte central do círculo cromático, está o eixo com 21 escalas de cores acromáticas (cinzas); as 
composições entre cada matiz e o eixo são denominadas de nuances claras, vivas, neutras e escuras.

O espaço de cores SCC é formado por dois tetraedros: a parte superior contém as cores da síntese aditiva (primárias RGB) e a união delas, no vértice, forma o branco; na parte inferior, estão as cores da síntese subtrativa, em cujo vértice se forma o preto, resultado da fusão das três cores do processo gráfico (primárias CMYK). Todas as relações apresentadas do sistema SCC estão representadas na figura abaixo.

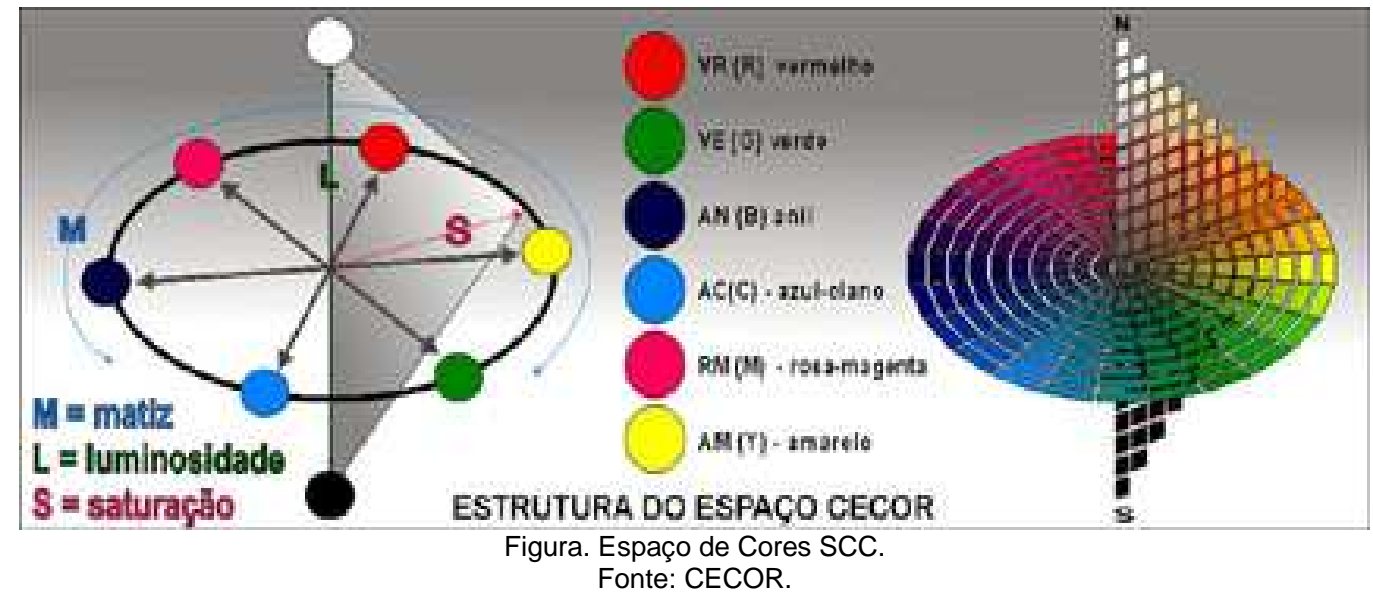

\subsubsection{Outros Sistemas de Notação Cromática}

Além dos sistemas de ordenação de cores apresentados neste Capítulo, outros são existentes; e possuem o mesmo objetivo central, o de organizar as cores para uma aplicação com maior precisão e com a possibilidade de discriminá-las corretamente. Entre outros, existe o sistema DIN, que foi desenvolvido, na Alemanha, com as diferenças perceptuais de matiz, saturação e luminosidade (FAIRCHILD, 2005); com os mesmos atributos, foi desenvolvido o sistema Coloroid, pelo Coloroid $A$. Nemcsics, a partir dos anos 80, apresentando diversas atualizações ao longo dos anos.

Por meio da explanação do tema, fica claro que não existe um sistema que constitua aceitação internacional como regra, nem que um seja melhor que outro, pois como cada um é baseado e desenvolvido segundo um princípio e método diferente, cada 
um aplica-se a um uso especifico da cor, existindo um sistema que contemple a todas disciplinas que abordam o uso das cores, tais como o desenho gráfico, a arquitetura, as artes plástica, a fotografia, a indústria têxtil, entre outras.

Caivano (1995a) esclarece, portanto, que os sistemas podem ser divididos em dois tipos: os sistemas de aparência da cor, que possuem base na percepção, caso do NCS e, os sistemas de estímulo de cor, que possuem metodologia na psicofísica, caso do CIE. 
CAPÍTULO 4 ASPECTOS COGNITIVOS DAS CORES 


\section{CAPÍTULO 4 ASPECTOS COGNITIVOS DAS CORES}

\subsection{ASSOCIAÇÕES E SIMBOLISMOS DAS CORES: INFLUÊNCIAS PARA O $D E S I G N$}

O hospital é um local carregado de simbologias, as simbologias a ele associadas partem de relações mantidas, ao longo de séculos, e que foram influenciadas, sobretudo, pelos ambientes hospitalares do período medieval; tais ambientes eram locais de morte e abrigo de doentes, em estados terminais; instituindo-se aos hospitais sentimentos negativos. Já as cores, elementos presentes na arquitetura, são uma das principais características do espaço, no processo de percepção visual, e também possui a característica de ser altamente expressiva, devido às associações e simbolismos a elas atribuídos.

A união da simbologia das cores à dos hospitais desenha um panorama perceptivo complexo, mas que pode delinear diretrizes projetuais para o design de interiores e para a arquitetura do ambiente hospitalar; ou ainda, simplesmente, aumentar o entendimento da complexa relação do ser humano - atitudes comportamentais e efeitos psicofísicos - com os ambientes hospitalares.

Os aspectos simbólicos que envolvem a cor partem de associações dessa às coisas, de maneira tal, que aquelas (as cores) passam a representar essas (as coisas). Por meio dessa representação, passam a desempenhar papel de signos, seguindo a definição de Caivano (1995b, tradução nossa): "Signo é algo que representa outra coisa, estando por ela, sendo que é entendido ou possui algum significado para alguém", essa definição de signo possui raízes na obra de Pierce, pai da semiótica² moderna. Ferrara (1999) salienta que o signo deve ser representado por meio de um sistema que seja legível; que seja capaz de se interpretar a substituição.

A cor, enquanto signo, age de várias formas e em vários locais, mas, sempre representando e se associando a alguma coisa. Vera Pallamin (1991, p. 17) exemplifica como age um signo, no caso, a cor: "Uma cor, por exemplo, torna-se apta a representar todas as coisas, sendo um certo ser e uma dimensão [...]".

\footnotetext{
${ }^{2}$ Semiótica: disciplina que se ocupa dos signos, do sentido e da comunicação (VOLLI, 2007).
} 
Em relação à qualidade de um signo expressar outra coisa, Caivano reafirma a cor como signo. Para ele, a cor está apta a representar coisas fora a ela e longe dela, variando de acordo com o contexto social e cultural, dessa forma, ele pondera que a cor não é uma estrutura previamente definida: "[...] sendo ela influenciada por vários fatores, é consequência do contexto em que é tomado [...]", e pode através dessa qualidade "[...] funcionar como signo para um fenômeno físico, para um mecanismo fisiológico e para uma associação psicológica" (CAIVANO, 1995b, p. 251, tradução nossa).

Pode-se citar como exemplo dessas relações o uso de composições cromáticas com predominância de tons verdes em ambientes hospitalares, uso que prevaleceu por muitos anos como padrão nesses ambientes; inclusive como Tofle et al. (2004) afirma tornando a cor da instituição "hospital", ou seja, a cor verde torna o ambiente institucional. Para Rousseau (1995), a simbologia contida relacionava-se, acima de tudo, à atribuição simbólica da cor verde com o sentimento de esperança, à fertilidade, ao nascimento e ao renascimento (GUIRAUD, 1973); esperança da cura da saúde, em um ambiente, simbolicamente, associado à morte.

Sabe-se pouco sobre como determinadas cores foram sendo associadas às coisas, o que se sabe é que, desde os tempos antigos, já havia essas associações (RASMUSSEN, 1974). A associação da cor a algo pode se dar por analogia ou semelhança. Essa associação parte do princípio de uma relação baseada na semelhança, e que remete a associações psicológicas, por exemplo, uma determinada cor que é associada a algo, que passa a representá-lo, e que remete a um determinado sentimento. Esse tipo de relação é denominado signo icônico (FERRARA, 1999).

As cores vermelha e amarela, segundo Rousseau (1995), estão na relação de semelhança ao fogo e ao sol, e são denominadas cores quentes. Segundo ele, essa denominação se dá por estarem associadas aos elementos "fogo" e "sol", que remetem ao calor e à quentura, e não por definições de temperaturas, no exato sentido da palavra. O mesmo ocorre com as cores, azul e verde, relacionadas ao céu e à água, e são classificados como cores frias, partem, portanto, de uma associação por analogia com sentimentos que figurativamente expressam frio e frescor, entre outros. 
Desde os estudos de Goethe (1993), a cor vermelha está relacionada às cores quentes, expressando sentimentos quentes ou positivos; associa-se ao vermelho à vivacidade, à agilidade e à aspiração (LUNDGREN, 2006; ROUSSEAU, 1995; ELLIOT et al., 2007); com uma relação antagônica, a cor azul associa-se às cores frias, possuindo a expressividade de sentimentos negativos, como a tristeza e a melancolia.

Sobre as qualidades das cores de expressarem sentimentos e emoções, através de associações, pode constatar-se na citação abaixo; nesta passagem, é possível verificar a imagem que a cor acarreta, verifica-se que de fato a cor está na pintura, mas o sentimento gerado (tristeza) por ela, não, ele é figurativo.

Ante mim há uma imagem de árvores e precipícios pelo mar, pintada com
cores fracas, expressando grande tristeza [...] a imagem literalmente possui
cores fracas e cinzentas, realmente pertence a classe das coisas fracas;
mas somente metaforicamente possui tristeza ou pertence a classe de
coisas que nos faz sentir triste. (GOODMAN apud LUNDGREN, 2006, p. 99,
tradução nossa).

Através das associações, é possível ir mais longe ainda, para alguns autores, que possuem uma vertente teórica de retorno à natureza como metodologia de pesquisa, a cor estudada através da experiência, na natureza, explica algumas características dela. Segundo Rousseau (1995), o verde, cor presente na maioria dos vegetais, relacionada às águas e cor denominada fria, é a cor complementar da vermelha, relacionada ao sangue, à vida e denominada cor quente.

No livro, A Linguagem das Cores, o estudo sobre as cores é, em grande parte, dedicado a estabelecer associações entre elas e as coisas (sexualidade, estado físico, elementos da natureza, etc.), com base nas experiências e em sua ocorrência na natureza; o estudo é dividido em efeitos físicos, os simbolismos e os fenômenos biológicos e psíquicos. No livro, os signos são considerados precedentes às descobertas e exprimem mais que a ciência, anunciando a noção de inconsciente coletivo, ou anima mundi, ou ainda, ciência infusa; Mahnke (1996) enumera o inconsciente coletivo como um dos fatores de influência no processo de percepção da cor.

O valor das associações reside no fato de que, de forma individual por meio das experiências pessoais de cada um, ou de forma coletiva, cujas associações estão 
incrustadas na sociedade pela cultura e tradição de cada povo, possui influência na vida cotidiana, na percepção (TUAN, 1980) e no julgamento que se faz (ARNHEIM, 1995).

Para Navit Kadar (2007), a cor é uma característica de superfície que ajuda o sistema visual no reconhecimento de imagens, mais rápido e mais eficientemente. Pode-se, frequentemente, lembrar-se de algo e identificá-lo através de uma cor (CAIVANO, 1995b). Com relação a esse aspecto, Dondis (1997) ressalta a força que a cor tem para o processo visual, podendo, ser usada para expressar ou intensificar a informação visual; pois, para ele, a cor não apenas tem um significado universalmente compartilhado, através da experiência, mas também, um valor informativo específico, que se dá através dos significados simbólicos a ela vinculados.

Segundo Kadar (2007), conforme seu estudo sobre o reconhecimento de memória, verificou-se que a cor é um dos elementos primários nesse processo, sendo um fator decisivo para o reconhecimento, senão primordial, usando-se da cor para distinguir e caracterizar objetos. Constata-se esse fato ao referir-se a um determinado objeto, (uma blusa) que para identificá-lo, usam-se as características da cor: a blusa marrom, o suéter azul. Mesmo que se usem outros signos, e às vezes, em que cada um faz referência a uma particularidade do objeto, os signos cromáticos quase nunca estão ausentes. Caivano (1995b) salienta que o fato de um signo nunca representar um objeto em sua totalidade, mas somente uma parte de seu aspecto, o reconhecimento do objeto não se esgota.

Essa é apenas um tipo de associação que se pode fazer, entretanto, muitas outras são possíveis. As cores podem ser adotadas como elemento de diferenciação de componentes químicos, informação de segurança e sinalização (CAIVANO, 1995b); no marketing, como instrumento de comunicação, como menciona Singh (2006), já Anter (2000) levanta outro aspecto. Para ela, a cor pode determinar um tipo específico de edificação, tornando visível seu caráter e sua identidade.

Outro tipo de emprego da cor pode ser exemplificado, na construção civil, a qual usa das cores para a diferenciação de tubulações (BATTISTELLA, 2003); em um hospital, cada tubulação possui uma cor associada (água, gás, oxigênio, etc.), de tal 
forma, que seja reconhecido seu conteúdo, estando tais associações definidas por normas e leis (ABNT-54/80), nacionalmente aplicáveis, constituindo um significado e, até mesmo, de forma universal, constituindo um símbolo, como é o caso do uso das cores nos semáforos, conclui Caivano (1995b).

Toda essa expressividade que a cor possui é assunto de extrema relevância para Arnheim (1995); fazendo um paralelo com o ambiente hospitalar, que também possui grande expressão espacial, constata-se são expressões ligadas diretamente ao ato de perceber e do sentir. Arnheim (1995) aponta que existe uma dificuldade em se compreender como isso ocorre, entretanto, mesmo sem uma explicação científica, as simbologias que a cor expressa é incontestável, "[...] aceito como fato universal [...]" afirma Caivano (1995b, p.256, tradução nossa).

As associações, segundo Tuan (1980), variam mais entre povos, culturas ou tradições diferentes de que entre pessoas de uma mesma sociedade; algumas simbologias são universais, outras não, variando de sociedade para sociedade.

Mesmo gerando muita polêmica, a cor é incontestavelmente aceita enquanto símbolo, como mencionado acima, e age diretamente no ambiente. No caso de um hospital, tal valor simbólico da cor se engrandece, pelo fato de associar-se a outro símbolo, também altamente significativo (COSTA, 2001). Um hospital lida com diferentes públicos com diversas características (faixa etária, nível social, entre outros), tornando um desafio prever as associações daqueles que o frequentam.

Malkin (2008) considera esse fator de extrema relevância ao se projetar edifícios hospitalares, pois, como a cor, que está presente na composição arquitetônica e é carregada de simbologia, compõe o ambiente hospitalar, deve-se fazer um levantamento prévio dos usuários daquele espaço, principalmente as características culturais locais, visando projetar um esquema cromático que beneficie os usuários daquele ambiente, comportando experiências positivas. 


\subsection{AS CORES E AS REAÇÕES HUMANAS}

\subsubsection{Efeitos Objetivos, Subjetivos e Psicofísicos da Cor no Ser Humano}

A cor, como citado anteriormente, pode ser um fenômeno físico, no âmbito da física, mas também, perceptivo, possuindo fundamentos na psicologia, portanto, seu estudo se dá na multidisciplinaridade. Uma das disciplinas que estudam as cores é a psicofísica, a qual engloba vários aspectos, de diversas áreas do conhecimento como a psicologia, a física e medicina (HUBEL, 1995).

Para a aplicação da cor na arquitetura, inclusive para a arquitetura hospitalar, faz-se de grande relevância um estudo abrangente dos variáveis aspectos da cor; em que, não somente suas qualidades físicas e químicas estão presentes, mas, sobretudo, suas qualidades psicológicas.

A psicofísica aplicada ao estudo da cor, foi de grande importância para o desenvolvimento dos estudos sobre os seus efeitos, no ser humano; efeitos que podem ser chamados de psicofísicos ou, psicofisiológicos, apontam Hubel (1995) e Mahnke e Mahnke (1996). Na figura abaixo, é possível verificar a formação das cores até suas consequências nas reações humanas. Passando por diversos âmbitos do ser humano.

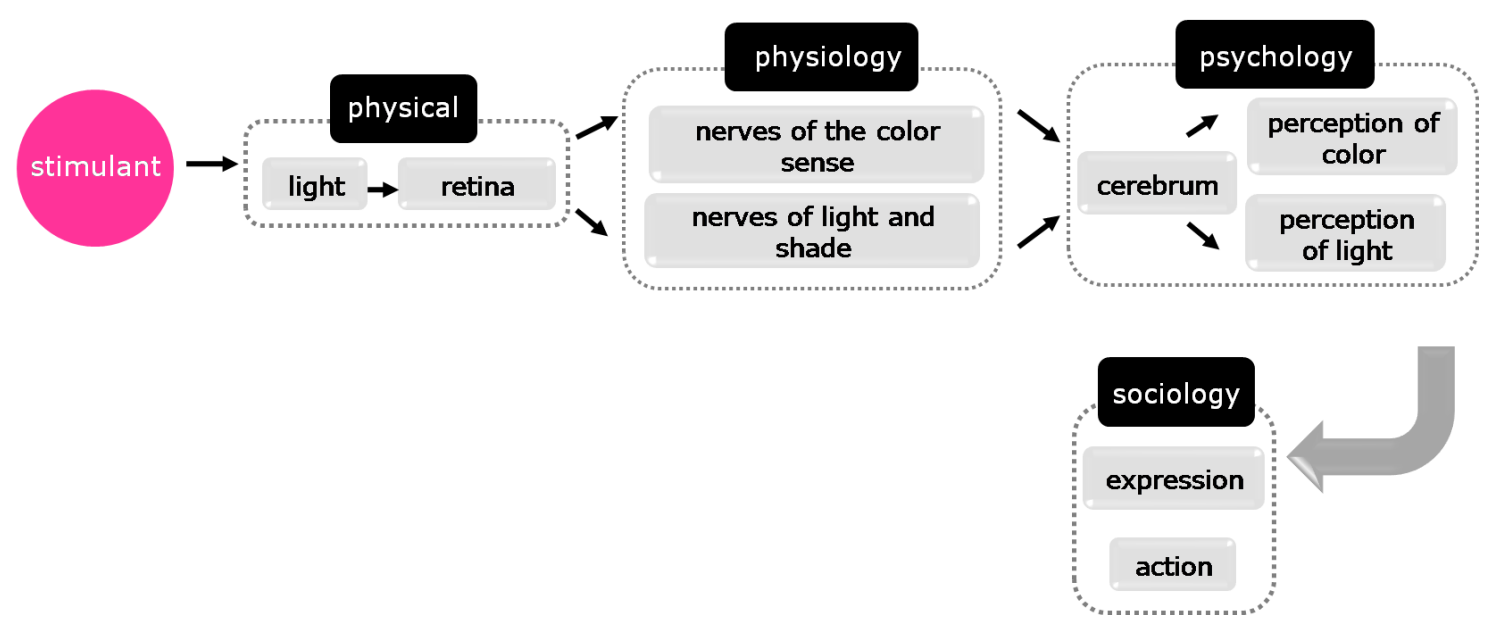

Figura 31 - Aspectos envolvidos na percepção cromática. Fonte: YU et al., 2009, p. 1971.

Sobre os estudos dos efeitos da cor, nos seres humanos, Mahnke e Mahnke (1996) afirmam que não é possível estudá-los objetivamente, mas somente subjetivamente, pelo fato de a cor ser fruto da percepção individual, sendo impossível mensurá-los. 
Contudo, para Kadar (2007), mesmo subjetivamente, os estudos sobre os efeitos da cor oferecem guias ou delimitam ações, que podem ser aplicáveis, delineando linhas de atuação.

No Capítulo Dois, foi mostrado que a percepção da cor está diretamente relacionada à atividade cerebral, através do córtex cerebral; os estudos da psicofísica relacionam as atividades cerebrais ao bem-estar do ser humano (BAKER, 2002), logo mensurar esses efeitos pode ser genuíno e prover padrões objetivos, especialmente em relação aos efeitos fisiológicos. Esses, ao ativarem o sistema nervoso, causam reações de ordem mensuráveis como, por exemplo, o aumento da pulsação.

Goldstein (apud MAHNKE; MAHNKE, 1996), na década de 40, já estudava os efeitos das cores, vermelha e azul, em pacientes, com problemas neurológicos como o "mal de Parkinson". Com base nesse e em outros estudos (ELLIOT et al., 2007; YU et al., 2009), que buscaram avaliar efeitos fisiológicos relacionados à cor vermelha, é que se atribuiu certas características e efeitos à cor vermelha. A partir dessas constatações, é que relacionam as cores de maior comprimento de onda a efeitos estimulantes; esse é um exemplo de pesquisa realizada sob os princípios da psicofísica.

$\mathrm{Na}$ atualidade, um dos mais importantes estudos sobre cor e comportamento humano, suas reações psicológicas e fisiológicas são desenvolvidas pelo Professor Byron Mikellides, membro da Universidade de Oxford. Alguns de seus estudos (MIKELLIDES, 1979) demonstraram uma relação de influência da cor, tanto na percepção de temperatura e memória, como também na noção de velocidade do tempo.

Os efeitos psicofísicos, que são em parte explicados pela física, estão frequentemente relacionados aos contrastes de cores, e que sofre influência direta da área da superfície a ser aplicada, conforme afirma Baker (2002). A percepção de uma parede pintada de vermelho em relação com a percepção de uma sala inteira pintada de vermelho é completamente diferente, segundo Lou Michel (1995), no segundo caso, é que é possível notar os efeitos associados àquela cor.

Portanto, conforme aponta Anter (2006) e Billger (2004), os efeitos psicofisiológicos estão diretamente relacionados à dimensão das superfícies coloridas, como 
também, ao entorno e contexto em que se encontram. Baker (2002) explana que uma parede, de grande escala, pintada com uma cor saturada causará maior efeito, que uma parede pequena, ou pintada com uma cor.

Outro fator relevante é que a constância de uma única cor, ou estímulo visual limitado, causa um efeito temporário, pois, logo em seguida, o organismo volta ao estado normal. Segundo Mahnke e Mahnke (1996), isso ocorre pelo fenômeno da adaptação da retina, fenômeno explicado pela teoria do tri-estímulo, anteriormente, apresentado, no Capítulo Três, que força a um equilíbrio do estímulo pela retina.

Nos parágrafos abaixo, será apresentado um panorama atual sobre as mais recentes pesquisas sobre os impactos da cor, na saúde e no estado psicológico dos seres humanos. Um hospital, em que a busca pela saúde é o objetivo maior, e que lida com a dicotomia saúde versus doença, levantarem-se as questões sobre as reações fisiológicas e biológicas humanas frente às influências da cor são tão necessárias quanto os seus impactos psicológicos, alguns dos estudos são regidos pelos princípios da psicofísica.

No Brasil, também existem pesquisas nessa área, o Laboratório de Eletrofisiologia e Psicofísica $^{3}$ do Núcleo de Neurociência da Universidade de São Paulo, estudam alguns dos temas, citados. Os principais objetivos do grupo de estudo é avaliar a visão das cores e de contrastes por métodos psicofísicos, diagnosticar funções visuais em indivíduos normais e efetuar avaliação neuropsicológica.

\subsubsection{Reações Fisiológicas e Biológicas}

Foram apresentados os conceitos da psicofísica e sua aplicação aos estudos dos efeitos da cor nos seres humanos. Os efeitos podem ser chamados psicofisiológicos, por agirem, nos sistemas biológico e fisiológico, e terem, em partes, suas explicações na física.

Pesquisas revelaram que as cores podem influenciar fisiologicamente mudanças, no crescimento de plantas. Sob a luz vermelha ou sob a luz de cores quentes, as

\footnotetext{
${ }^{3}$ Laboratório da Visão: Psicofísica e Eletrofisiologia Visual Clínica. Departamento de Psicologia Experimental - Instituto de Psicologia. Núcleo de Apoio à Pesquisa em Neurociências e Comportamento. Universidade de São Paulo. (www.ip.usp.br/laboratorios/visual/index2.htm)
} 
plantas reagem mais positivamente, tornando-se ativas; sob estímulos de luz azul, os resultados mostraram que as plantas tendem a permanecer inativas ou ter seu crescimento mais lento (BIRREN, 1978).

Já, na fisiologia humana, as principais constatações giram em torno dos resultados clínicos que envolvem a pulsação, oxigenação, frequência cardíaca e pressão sanguínea, conforme as pesquisas de Elliot et al. (2007) e Kaiser (1997,1964); no âmbito da psicologia, as principais verificações são referentes aos sentimentos emocionais subjetivos experimentados, aponta Singh (2006).

A pesquisa de Yu et al. (2009) teve por objetivo constatar reações fisiológicas nos seres humanos, embasado em seis cores diferentes. As pessoas, em um quarto, eram submetidas à estimulação dessas cores, por um determinado período de tempo, enquanto que eram avaliados seus estados fisiológicos e, posteriormente, psicológicos e emocionais. Obtiveram como resultado que as cores, denominadas quentes, afetam o sistema nervoso parassimpático positivamente, acalmando o corpo e a mente. Os resultados obtidos vão de encontro, com a noção universal, de que as cores quentes ativam o sistema nervoso simpático, e as cores frias, o sistema nervoso parassimpático.

Outro estudo importante, nesse campo, foi desenvolvido por Latrobe Fellowship, formando representantes de três diferentes áreas de atuação: um escritório de arquitetura - Chong Partners Architecture, um hospital de referência - Kaiser Permanente e uma universidade - Universidade da Califórnia. O objetivo do grupo também foi desenvolver pesquisas sobre as influências da cor nos efeitos fisiológicos do ser humano (EDELSTEIN, 2008).

As pesquisas do Latrobe Fellowship vêm sendo desenvolvidas desde 2005, e apresentaram resultados relevantes,eles constataram alterações na glândula pineal, responsável pela liberação de uns dos principais hormônios, a melatonina que, por sua vez, regula o ciclo circadiano. O ciclo circadiano causa influências no sono, na alimentação, no crescimento e no sistema reprodutivo e imunológico.

Outros estudos mostraram que ambientes com cores de menor luminosidade tendem a provocar atividades no cérebro que podem induzir à ansiedade, ao medo e à angústia, de acordo com Mahnke e Mahnke (1996); em contrapartida, ambientes 
com cores mais saturadas estimulam o sistema nervoso, aumentando a oxigenação, a pulsação e o ritmo cardíaco (YU et al., 2009). A atividade cerebral é mais baixa em ambientes coloridos que nos acromáticos (como o cinza) e, o coração responde de forma mais lenta em ambientes coloridos (MAHNKE; MAHNKE, 1996).

Outra característica observada é que ambientes com cores fortes e alta luminosidade tendem a produzir maior efeito de estimulação, e as cores com baixa luminosidade causam uma sensação calmante, mas que também, podem causar sentimentos depressivos, afirmam Baker (2002) e Lundgren (2006).

Assim sendo, desejando-se aumentar as respostas aos efeitos psicofisiológicos, pode-se utilizar a variedade cromática, que é um recurso para a criação de variedade de estímulo visual; tema que será, posteriormente, debatido amplamente. Neste sentido, considera-se que uma composição cromática baseada, na variedade de estímulo visual é recomendada, mais que seguir regras de harmonia cromática, ou do uso específico de uma determinada cor e seu efeito singular, como diretriz projetual, para o design dos ambientes hospitalares.

Os resultados, mesmo sendo criticados, revelam certas recorrências que apontam algumas tendências. De qualquer forma, a literatura levantada mostra que a cor, seja a usada por meio da iluminação seja a usada por meio de objetos coloridos, pode alterar reações fisiológicas.

Os assuntos apresentados mostram a complexidade do tema e também revelam um amplo campo ainda a se desvendar. Muitos estudos, em fase de andamento são desenvolvidos focando o ambiente hospitalar, pelo fato de o hospital englobar várias disciplinas e por estar diretamente relacionado às questões da saúde.

\subsubsection{Reações Psicológicas e Comportamentais}

Outra vertente de pesquisas sobre os efeitos das cores no ser humano, está relacionada às reações psicológicas e comportamentais. As reações psicológicas são tão fundamentais quanto às fisiológicas, uma vez que o efeito psicológico age como um elemento determinante no processo terapêutico, podendo auxiliar na recuperação da saúde e no bem-estar. Para Okamoto (1996), como também para 
Anter (2000), a dimensão psicológica do ser humano desperta emoções e sentimentos, assim como sensações, os quais influem diretamente no seu bemestar.

Muitos estudos desenvolvidos, nesse campo, mostram a relação das cores com a sensação de sabores, odores, comportamento, humor e até mesmo no desempenho de certas atividades. Outro fator relevante é a questão da preferência de cores, muitos estudos são realizados nesse campo. As pessoas gostam ou não de determinadas cores e, de certa forma, essa preferência acaba por afetar os sentimentos que despertam nelas; uma pessoa que goste de preto não se sentirá impactada negativamente como uma outra que não goste, e a associe à morte, por exemplo: são percepções diferentes. A personalidade e as reações aos estímulos, portanto, muito dependem das preferências, conforme indicam as pesquisas de $\mathrm{Ou}$ et al. (2005), Billger (2004) e Billger e Anter (2006).

As cores podem gerar ações de aproximação ou dispersão, alterar a percepção de volume, de peso, de dimensão e de tamanho. Assim como podem também alterar a noção de tempo, de temperatura, e de som. A noção de que a cor pode interferir, no comportamento individual, repousa sobre a hipótese de que as ondas de luz de maior comprimento podem produzir um efeito direto, no sistema endócrino através da glândula pineal, ativando, por exemplo, um comportamento agressivo. Essas considerações sobre os efeitos da cor são encontradas nos seguintes autores: Mahnke e Mahnke (1996), Billger (2004), Billger e Anter (2006) e Kadar (2007).

Elliot et al. (2007) fizeram uma pesquisa sobre a influência da cor vermelha no desempenho de funções. Através de seis experimentos desenvolvidos de diferentes formas e métodos, inclusive utilizando o EEG (Eletroencefalografia - estudo do registro gráfico das correntes elétricas no cérebro); os resultados obtidos confirmam a hipótese de que a cor vermelha de fato influi no desempenho de atividades. Para eles, o resultado alcançado pode ser considerado concreto, pois os experimentos foram apoiados por múltiplos suportes metodológicos, inclusive por uma abordagem perceptiva, além da fisiológica analisada por exames clínicos.

Muitos estudos, quando revisados, não obtiveram os mesmos resultados. Segundo Kadar (2007), o fato de não ser possível reproduzir condições ideais e, contar com a 
particularidade do indivíduo, que estabelece uma relação de associação individual entre as cores e as emoções e sentimentos que despertam, torna difícil a tarefa de gerar um padrão de cor ideal para determinados objetivos. O que mostra a literatura pesquisada é que podem existir associações mais comuns e recorrentes, como os efeitos do vermelho e as percepções em torno do azul, inclusive permanecendo entre povos distintos.

Todavia, para muitos estudiosos, a literatura sobre as relações de cor e saúde, nas reações comportamentais e nos estados emocionais, é insuficiente para provarem a influência da cor nessas reações, com bases na ciência, que produzam padrões de aplicação. No entanto, esse fato não diminui sua relevância, ou muito menos, exclui sua importância na aplicação no ambiente hospitalar. Somente mostra que se deve usar a cor, com cautela. Os inúmeros estudos, aqui apresentados, são exemplos concretos da influência da cor no ser humano e mostram algumas direções, quanto ao uso da cor, no ambiente hospitalar.

\subsection{EMOTIONAL COLOR: UMA ABORDAGEM ATUAL PARA COMPOSIÇÕES CROMÁTICAS NA ARQUITETURA}

No campo da arquitetura, os estudos sobre a aplicação das cores mais recentes ultrapassam as características físicas e as suas propriedades. Na Suécia, onde atualmente estão concentrados os mais novos e importantes estudos sobre cor e arquitetura, a nova abordagem é a questão emocional da cor, a relação dos efeitos das cores às emoções humanas.

Em um ambiente onde a principal função é acolher e tratar a doença, a carga psicológica é muito grande. As emoções, os medos, os anseios e, principalmente, as expectativas contribuem para tornar aquela experiência hospitalar, carregada de simbologias, muitas vezes traumática. E é, nesse sentido, de minimizar as emoções negativas e o stress que as composições cromáticas vêm sendo aplicadas no ambiente hospitalar.

Os estudos sob essa abordagem tentam relacionar e demonstrar através de inúmeras metodologias como pesquisas, exames laboratoriais e equações matemáticas, que as cores despertam emoções nos seres humanos, e que podem 
determinar padrões de uso, baseados em evidências, que por uma vez quando aplicados, no ambiente, remeta às intenções pré-estabelecidas. Kadar (2007, p.28, tradução nossa) referindo-se a esse assunto, menciona: "As associações, entre cor e emoções, são frequentemente usadas, em composições clínicas como ferramenta terapêutica, para aumentar a habilidade de expressar sentimentos traumáticos profundos".

As avaliações clínicas mostraram que o ser humano reage psicofisiologicamente às cores, afetando o funcionamento do cérebro e do biorritmo, influenciando comportamento e sentimentos. Mas, conforme aponta Lou Michel (1995, p. 89, tradução nossa), não está claro quando isso acontece e como ocorre, o que se sabe é que as principais reações ocorrem no sistema endócrino; "[...] as glândulas pineais interagem com as ondas eletromagnéticas da cor e essas ativam células do organismo [...]".

Ao se falar em reações emocionais, a problemática do tema gira em torno do complexo estado da mente que, segundo Da Pos e Green-Armytage (2006), incluem correlações psicológicas, regras sociais e fatores cognitivos. Segundo eles, são as emoções que dão às pessoas energia para reagir, no comportamento, de forma a gerar o bem-estar e controlar as situações. As manifestações de emoções, relacionadas às cores, podem ser respostas como expressões faciais, ou ainda, em mudanças no sistema nervoso central, que, conforme afirma Kadar (2007), essas implicam em muitas funções cognitivas. Devido a essas qualidades das emoções, os estudos, nesse campo, vêm cada vez mais crescendo, podendo ser uma vertente para a formulação da composição cromática, visando obter resultados emocionais.

A possibilidade de se controlar, ou induzir a um estado emocional, por meio da arquitetura, é um tema de extrema importância. Tratando-se de um hospital, essa possibilidade aumenta consideravelmente pelo fato de poder auxiliar ainda no processo de cura do paciente; é um desejo um tanto alto, mas real e pertinente, pois como já visto anteriormente, muito antes da arquitetura ser apenas um abrigo das atividades médicas foi considerado como agente de cura (FOUCAULT, 1998), e que, aos poucos perdeu esse papel que desempenhava. 
O emocional das cores é estudado de variadas formas e aplicadas com diferentes métodos e instrumentos (HARLEMAN, 2004; OU et al., 2005; SATO et al., 2005; STAHRE; HARLEMAN; BILLGER, 2005), uns estudos utilizam da arquitetura como meio de investigação, ou seja, como as emoções são despertadas a partir da percepção das cores em ambientes reais, outros utilizam simulações de computadores como instrumento de aplicação das pesquisas.

Segundo algumas pesquisas, a relação entre cor e emoção está arraigada na biologia humana, e devido a isso, pode gerar uma possível descrição de regras correspondentes entre eles. Para Da Pos e Green-Armytage (2006, 2007), as pessoas reagem de forma igual ou parecida através de expressões faciais, decorrentes de fatores emocionais como respostas às cores.

Oberascher; Oberascher e Gallmetzer (2005) compararam o significado emocional das cores em diferentes culturas; os resultados mostraram um alto consentimento entre emoção e cor, mas também diferenças entre grupos culturais diversos. Outro estudo relevante nesse campo é realizado por Da Pos e Valentini (2005), em que através de outro método investigou a assimilação de emoções humanas denominadas básicas ${ }^{4}$ com as cores. Os resultados indicaram uma tendência de assimilação entre certas cores com determinadas emoções. Por exemplo, a recorrência das colorações avermelhadas e azuladas, associadas às emoções escuras, e de medo, em contrapartida, dos amarelos relacionados à felicidade.

Um complicante dos estudos entre cor e emoção, é que as emoções não são causadas por puras percepções de cor, mas dependem, em grande parte, da situação e do contexto. Frequentemente, nós somos fortemente afetados pelos códigos culturais e conotações amarradas às cores em situações específicas que, em alguns casos, podem interferir no resultado ou, até mesmo, no julgamento que se faz (TAKAHASHI, 2009; HARLEMAN, 2004).

Outro fator decisivo para a avaliação positiva ou negativa entre a relação cor e emoção em determinados edifícios ou ambientes, é a expectativa. Para Billger e Anter (2006), preferimos uma cor que nos faz sentido e, que pode ser amplamente utilizada em determinado ambiente ou edifício, e reagimos negativamente quando

\footnotetext{
${ }^{4}$ Emoções básicas são aquelas recorrentes em todas as culturas e fundamentalmente universais, e que a expressão externa, invariavelmente, muda de pessoa para pessoa ou cultura (DA POS; GREEN-ARMYTAGE, 2006; DAVIDOFF, 2004).
} 
não encontramos uma razão em seu uso, ou seja, difere daquilo que esperávamos que fosse.

Os estudos entre cor e emoção, ou o emocional das cores - como também pode ser traduzido, da expressão original color emotional - ampliam as discussões sobre os efeitos das cores nos seres humanos, mas sobretudo, podem mostram um caminho para o uso das cores no ambiente hospitalar; alguns dos projetos hospitalares mais recentes vêm se utilizando de alguns desses estudos como suporte e embasamento para as decisões projetuais das composições cromáticas

Com relação à dificuldade em se provar e mensurar as reações das cores, Tuan (1983, p. 222) completa dizendo: "Uma grande quantidade de dados provenientes da experiência está destinada ao esquecimento por que não podemos encaixar as informações, nos conceitos das ciências físicas que aceitamos sem criticar".

Mas, mesmo assim, com todas as controvérsias e dúvidas com relação ao papel das cores nas reações humanas, fica evidente que a cor desempenha um papel mais que relevante em nossas vidas, ela é um dos motivos para terem-se os olhos, seguindo a direção da teoria de Goethe ou, voltando-se para a representação da beleza em nossas vidas por meio das luzes, para os neoplatônicos ${ }^{5}$; saindo da esfera filosófica, a cor, um elemento da arquitetura, que, ao mesmo tempo, transforma a própria arquitetura também, é um elemento transformador dos seres humanos.

\footnotetext{
${ }^{5}$ Vertente filosófica que encerra os conhecimentos propostos pelo filósofo Plotino. A concepção de beleza está contida na unidade do todo (luz e cor). (PULS, 2006, p. 118).
} 
CAPÍTULO 5 O USO DAS CORES NA ARQUITETURA: QUESTÕES PERCEPTIVAS E APLICAÇÕES PRÁTICAS 
CAPÍTULO 5

O USO DAS CORES NA ARQUITETURA: QUESTÕES PERCEPTIVAS E APLICAÇÕES PRÁTICAS.

\subsection{BREVE HISTÓRICO: ARQUITETOS, ARQUITETURAS E AS CORES}

"Nosso ambiente construído não é experimentado como um ambiente acromático, sem vida. Ao invés disso, ele é moldado por sombras e luzes, pincelado por várias cores, saturadas ou intensas [...]" (SMITH, 2004, p. 106, tradução nossa).

Segundo Caivano (2006), uma das primeiras referências sobre o uso da cor, na arquitetura, é encontrada em Vitruvius, arquiteto romano, que viveu no séc. I; a abordagem de Vitruvius era sobre as cores naturais, com um foco voltado para a descrição delas. Já em Leon Battista Alberti, outra postura é encontrada. Em seu livro On Paiting (1435), a abordagem sobre a cor é mais abstrata e filosófica, relacionando-a com a luz e fazendo uma classificação das cores, inclusive com referências ao valor afetivo e emocional.

Mesmo antes de Vitruvius, é relatado, na literatura o uso da cor, na arquitetura, que os egípcios e os povos da antiguidade usaram desse artifício como elemento visual, decorativo, artístico e mesmo arquitetônico para compor suas vidas (DAY, 2007).

No entanto, ao longo da história da arquitetura, nem sempre a cor teve papel de protagonista entre os arquitetos. Segundo Rasmussen (1974), o uso da cor, na arquitetura, foi inicialmente acidental, pois, segundo ele, as cores do cenário arquitetônico eram decorrentes das características dos materiais utilizados, sendo esses que definiam a coloração das construções. Os materiais utilizados eram aqueles mais fortes e úteis, consequentemente eram os que predominavam na paisagem, constituindo certa identidade e constância. Dessa forma, a habitação humana tinha as cores da natureza, ou seja, dos materiais que a própria natureza Ihes proporcionava.

Com o domínio de novas técnicas construtivas, que tinham primordialmente o objetivo de aumentar a durabilidade dos materiais, novas cores foram introduzidas à paisagem e à arquitetura. Segundo Rasmussen (1974), um exemplo é a argila, que 
quando cozida, gerava outros tons como vermelhos e amarelos e que apareciam, na predominância das terracotas originais. A relação, cor e material, sempre estiveram intimamente juntas, pois segundo ele, não se consegue ver um material separado de sua cor, considerando a cor uma propriedade intrínseca do material.

Para Rasmussen (1974, p. 219), o uso das cores, na paisagem, sempre remeteu aos materiais e cores predominantes da região como uma forma de imitação ou ainda como diz: "[...] de pouca criatividade [...]", e proporcionava uma continuidade cromática à paisagem natural.

Outro exemplo de uso das cores com essas características são as casas rurais da Noruega que, culturalmente, são pintadas de vermelho vivo, remetendo a um tipo de material mais duradouro, e que tem a cor vermelha; portanto, a ideia por detrás do seu uso é que ao se copiar a cor do material original, passar-se-ia a ideia de durabilidade da construção.

O uso da cor, na arquitetura, nem sempre fora visto da mesma maneira, principalmente pelos arquitetos, muitos a submetiam a segundo plano, como um elemento meramente decorativo, sem importância representativa.

\begin{abstract}
A ideia de forma precede isso de cor. A forma é preeminente, a cor é, mais um de seus acessórios. A cor depende completamente da forma material: por exemplo, o conceito de esfera precede o conceito de cor; é concebido como uma esfera incolor, a cor não é concebida independentemente de algum suporte. A cor é coordenada com forma, mas o recíproco não é verdade. Nós acreditamos, assim, que um tema deveria ser selecionado para suas formas e não para suas cores. (LE CORBUSIER, OZENFANT apud CAIVANO, 2006, p. 354, tradução nossa).
\end{abstract}

O texto acima escrito, em 1918 por Le Corbusier e Amédée Ozenfant, ilustra o pensamento do início do século XX. Para Le Corbusier, a cor era vista como uma forma de degeneração, não sendo uma qualidade da arquitetura; para os modernistas, tal ideal representou uma concepção de uso da cor branca prevalecendo como a cor do movimento moderno na arquitetura, a qual englobava todos os valores defendidos por eles: saudável, limpo, moral e racional (MINAH, 2008; RASMUSSEN, 1974). Contudo, Le Corbusier rende-se às cores, com uma visão similar a de Fernad Léger (apud CAIVANO, 2006, p. 354, tradução nossa) que diz: "O homem precisa das cores para viver, isto é um elemento necessário assim como a água e o fogo [...]" 
Ao contrário da maior parte dos arquitetos do movimento modernista, Walter Grooupis, uma expressão da arquitetura moderna, dedicou-se aos estudos sobre as cores na Bauhaus, juntamente com Wassily Kandinsky, Paul Klee, Josef Albers e Johannes Itten, esses, referências mundial da literatura sobre o estudo das cores.

Fora os estudos da Bauhaus, outra experimentação com cores no modernismo foi feita pelo movimento De Stijl. Movimento de 1917, originado das pinturas abstratas de Piet Mondrian e, que segundo Galen Minah (2008), ajudou a divulgar o uso das cores na arquitetura, introduzindo a questão da cor como determinante para o espaço e, conforme aponta Rasmussen (1974), opondo-se à visão tradicional que considera o uso da cor como adorno decorativo.

A partir do início do século $X X$, formam-se duas correntes bem definidas quanto ao uso da cor na arquitetura. A primeira diz respeito àqueles que atacavam o uso das cores, como efeito meramente decorativo, caso dos movimentos do purismo e racionalismo segundo Caivano (2006), e que mais tarde ficou conhecido como estilo internacional da arquitetura moderna. A segunda, uma vertente que defendia o uso das cores na arquitetura, produzindo uma arquitetura policromática, caso do arquiteto alemão Bruno Taut, o qual visava à utilização da cor natural dos materiais, como expressão de sua cor inerente.

Para muitos arquitetos, o uso da cor na arquitetura, é um artifício que serve para encobrir defeitos ou erros do espaço e para disfarçar algumas características não desejáveis na percepção do espaço construído. No entanto, Steen Rasmussen (1974) defendia o uso da cor na arquitetura, não para mascarar erros ou falsificar sensações, mas sim, para acentuar as características espaciais. Para ele, (RASMUSSEN, 1974, p. 221, tradução nossa):

[...] o piso deveria ser mais escuro como a terra que pisamos, para dar a sensação da gravidade [...] as paredes, por outro lado, deveriam ter cores variadas, como os arbustos floridos e as árvores [...] E por fim o teto deveria ser claro e aéreo, ou de delicadas sombras rosa e azuis, como o céu sobre nossas cabeças.

Ele ainda considera que a forma, para a arquitetura, é o que a caracteriza, uma vez que essa articula o espaço. No entanto, a cor, um elemento da arquitetura deve ser usado como articulador da composição arquitetônica. Mas, o que prevaleceu e ainda hoje prevalece é o domínio da forma sobre a cor. Cada arquiteto, embasado em 
determinadas metodologias, especifica como será o esquema cromático em seus projetos. Fora os arquitetos que utilizam em suas produções a integração entre cor e forma, e a cor como elemento representativo do conceito, ainda, na fase de concepção inicial do espaço, caso do arquiteto Lois Kahn, a grande maioria projeta considerando somente a forma e, por vezes, não prevê um esquema cromático, nem a utiliza como elemento representativo do conceito; quando o ideal é que fossem pensados juntos, uma vez que, como será visto, um interfere no outro.

Ao longo do séc. XX e séc. XXI, houve várias expressões mundiais do emprego da cor na arquitetura, que se destacaram. Para Caivano (2006), podem ser citados: Luis Barragán (México), Aldo van Eyck (Holanda), Mario Botta (Suíça), Aldo Rossi (Itália), Jean-Philippe Lenclos (França), Lourdes Legorreta (México), Michael Lancaster (UK). No campo específico da arquitetura hospitalar, um dos nomes que mais se destacam, sendo referência mundial na área, é o da arquiteta americana, Jain Malkin. Ela possui ampla produção na área e também contribui com pesquisas, tendo publicado alguns livros.

O uso das cores, na arquitetura, é amplo e variado; pode estar seu uso relacionado às tradições ou contexto cultural, às tendências e modismos, às conceituações de projetos e, a muitos outros fins; e ainda seu uso ser aplicado em diversos meios. Enfim, como se usam as cores depende dos fins, objetivos, metas e conceitos; contudo, tal tarefa ser, primeiramente, atribuída ao arquiteto, devendo esse ter o conhecimento de todos os aspectos relacionados às cores, para que em sua aplicação reflita a intenção inicial, sendo transmitida e reconhecida, corretamente.

Brady e English (2000) apontam que a importância da cor, na arquitetura, vai além da necessidade de despertar a sensibilidade, para eles, a importância reside no fato de possibilitar a criação e compreensão dos elementos arquitetônicos do espaço, a informação é dada pela interação da cor, da luz e da configuração espacial, salientando a relação das partes com o todo.

Nesse esquema de composição da arquitetura, a cor deve participar da construção da experiência visual, reforçando ou negando os aspectos estruturais e espaciais. Assim, o uso da cor, na arquitetura, envolve muito mais do que a aplicação de uma fórmula ou paleta de cores, ressalta Galen Minah (2008). 


\subsection{CONSIDERAÇÕES ACERCA DA COR NA ARQUITETURA}

\subsubsection{Percepção Ambiental: Introdução à Percepção Espacial}

No Capítulo Dois, foi abordada a questão das diferenças entre ver e perceber a cor. Para tanto, levantou-se um estudo da percepção visual, partindo do conceito que anterior à percepção do espaço, tem-se a percepção visual, pois uma dá suporte à outra, reconhecendo aquela anterior a essa. Com isso, foi possível formular uma visão ampla da formação da cor, compreendendo, inclusive, o sistema visual.

Agora, com o entendimento dos aspectos mais importantes sobre as cores, chegouse a sua implicação prática, ou seja, sua aplicação na arquitetura, e as consequências dela à percepção espacial. Portanto, visando à perfeita compreensão dos aspectos envolvidos, na relação cor e arquitetura, serão apresentados os principais conceitos que envolvem a percepção ambiental.

A formação do processo de percepção ambiental se dá, no conhecimento da espacialidade, área de estudo da Psicologia Ambiental; mas, que tem têm sido estudada em outras áreas de conhecimento, como é o caso da Arquitetura. Os estudos relacionam o comportamento humano construído por meio da estrutura espacial.

Del Rio (1996) considera a percepção como um processo mental, de interação do indivíduo com o meio ambiente, que se dá através de mecanismos perceptivos propriamente ditos e, principalmente, cognitivos. Sendo os primeiros mecanismos dirigidos pelos estímulos externos, captados através dos cinco sentidos, em que a visão é o que mais se destaca, os segundos são aqueles que compreendem a contribuição da inteligência, conforme afirma Del Rio (1996, p. 5): "[...] a mente não recebe essas sensações passivamente: existem contribuições ativas do sujeito ao processo perceptivo desde a motivação à decisão e conduta.”.

Para Tuan (1983), a percepção ambiental pode ser definida como sendo uma tomada de consciência do ambiente pelo homem, e Lucrecia Ferrara discute a questão da percepção ambiental como informação, conforme cita (1999, p. 153): "Percepção é informação [...] que se revela na medida em que é submetido a uma 
operação que expõe a lógica da sua linguagem". Portanto, segundo seu ponto de vista, a percepção ambiental gera conhecimento a partir da informação retida, codificada em usos e hábitos daquele determinado lugar, "perceber é ver e reconhecer, em consequência, a informação não é criada ou processada, mas simplesmente absorvida" (FERRARA, 1999, p.177).

No livro, Percepção Ambiental e Comportamento, Okamoto leva o tema à exaustão no qual apresenta de forma abrangente as várias abordagens sobre o tema; com relação à arquitetura enquanto linguagem ele nos fornece um esquema, abaixo representado, que elucida o processo da percepção ambiental (OKAMOTO, 2002, p. 41):

\section{Sensação $\Longrightarrow$ Emoção $\Longrightarrow$ Pensamento $\Longrightarrow$ Ação}

No esquema, a sensação é o momento de percepção do espaço, como cor, forma e profundidade; à medida que se percebe o espaço, o ser humano é tomado pela emoção, pelo sentimento que o espaço imprime ou a simbologia nele contida, em seguida, o ser humano reflete sobre o espaço, confrontando-o com suas experiências anteriores, interpretando a mensagem nele contida. O resultado da reflexão é o comportamento humano. Cada indivíduo percebe, reage e responde diferentemente às ações sobre o ambiente em que vive; as respostas decorrentes são resultados das percepções, dos processos cognitivos, julgamentos e experiências anteriores de cada pessoa.

Com relação à experiência, citada acima, Tuan (1983, 1980) a considera um fator importante no processo perceptivo, conforme cita (1983, p.10): "[...] a experiência implica a capacidade de aprender, significa atuar sobre o dado e criar a partir dele". Em uma metáfora de Susane Langer (apud TUAN, 1983, p.10), fica evidente seu posicionamento frente à relevância da experiência: "[...] o mundo da física é essencialmente o mundo real interpretado pelas abstrações matemáticas, e o mundo do sentido é o mundo real interpretado pelas abstrações imediatamente fornecidas pelos órgãos do sentido".

Tal valorização da experiência se funde em uma questão essencial ao ser humano que é a de aprender, e que para Tuan (1983), tanto o pensamento como o sentimento são formas de se conhecer o mundo. Já Arnheim (1995) explora os 
estímulos visuais, anteriores ao funcionamento da percepção, nos quais debate a questão da qualidade das unidades visuais individuais e as estratégias de sua unificação em um todo final e completo, conforme cita:

Em todos os estímulos visuais e em todos os níveis de inteligência visual, o significado pode encontrar-se não apenas nos dados representados, na informação ambiental e nos símbolos, inclusive a linguagem, mas também nas formas compositivas que existem ou coexistem com a expressão factual e visual. Qualquer acontecimento visual é uma forma com conteúdo, mas o conteúdo é extremamente influenciado pela importância das partes constituídas, como a cor, o tom, a textura, a dimensão a proporção e suas relações compositivas com o significado. (ARNHEIM apud DONDIS, 1997, p. 22).

$\mathrm{Na}$ citação acima, Arnheim introduz dois temas relevantes para o assunto em questão: a dos símbolos da linguagem arquitetônica e a dos elementos que compõe a arquitetura, ou seja, o espaço.

Referindo-se ao primeiro assunto, inúmeros são os escritores que estudam a arquitetura enquanto linguagem e seus símbolos, a semiótica é a ciência destinada a esse estudo. Pierce ${ }^{6}$ é considerado o precursor da semiótica moderna e seu legado influenciou muitos estudos sobre o tema; a linguagem é o processo de comunicar uma mensagem entre dois sujeitos, sendo um o emissor e o outro o receptor; entre os sistemas de significação-comunicação estão: a fotografia, o cinema e a pintura.

Assim, o arquiteto, usando o espaço como código de comunicação, elabora sua mensagem, usando uma linguagem específica - a linguagem do espaço construído, constituindo assim um sistema de significação: a arquitetura.

Del Rio (2002, p. 315) faz referência a alguns elementos relevantes: "A construção do sentido do espaço se dá, portanto, por meio da elaboração de uma estrutura cognitiva composta de elementos que nos são dados pela experimentação do mundo objetivo." Ele esclarece que "[...] toda representação se faz através de signos. Um que um signo é aquele que representa algo para alguém; supõe, portanto, um objeto que é representado e um receptor a quem se dirige a representação [...]" (DEL RIO, 1996, p.62).

Nos estudos de percepção ambiental, o espaço tem papel de protagonista no sistema de significação. O espaço construído é constituído de signos que agem

\footnotetext{
${ }^{6}$ Pierce, fundador da semiótica e do conceito de representação. (DEL RIO, 1996, p. 62).
} 
como instrumentos dessa linguagem. Segundo Zevi (1996), a leitura dos símbolos resulta, na percepção visual, no qual formas, texturas e cores são prontamente observadas, Durand (apud MARTINEZ, 2000, p.20) conclui: “[...] os elementos estão para a arquitetura como as palavras para a linguagem; como as notas para a música, sem o seu perfeito conhecimento é impossível seguir adiante".

A percepção dos objetos abrange, portanto, o reconhecimento dos objetos e para tanto envolvem análises de características, que consiste em um processo de detecção de elementos específicos. Começa-se com os componentes de uma forma, como borda, linha, cantos e, com isso, constrói-se a percepção da forma (HUBEL, 1995; ARNHEIM, 1995). Essa teoria é reforçada pelas descobertas de Hubel e Wiesel (1995) que mostraram que as células do córtex cerebral funcionam como detectores de características altamente especializados.

Em conformidade com os conceitos acima descritos, está a base da psicologia da Gestalt', a qual considera que a primeira sensação já é de forma global e unificada, pois, em seus conceitos, considera-se que não vemos partes isoladas, mas relações, isto é, uma parte na dependência de outra parte. Outro ponto de vista da teoria da Gestalt é a relação psicofisiológica, que consiste em que toda forma psicologicamente percebida está relacionada com as formas integradoras do processo fisiológico cerebral.

Demonstrar o enredamento das relações entre o ser humano e o ambiente foi o objetivo das explanações acima, para mostrar como o conhecimento dos conceitos da percepção espacial pode influir, na concepção arquitetônica, pelo simples fato de o espaço ser composto por elementos, que podem ter inúmeras combinações, e que cada combinação terá um resultado particular, proporcionando uma experiência espacial única.

Ao se projetar um espaço arquitetônico, especificamente, o espaço hospitalar, em que os sentimentos e emoções estão ainda mais suscetíveis, o conhecimento das características e dos elementos da percepção espacial é fundamental para que o espaço construído contemple os anseios dos usuários e seja positivo para o seu processo terapêutico.

7 Gestalt, palavra alemã que significa Forma (GOMES (2000). A Gestalt tem bases filosóficas e é uma das quatro abordagens da Psicologia. Sob determinada perspectiva, por psicologia, entende-se a ciência que estuda o comportamento humano. 
Sendo a cor um dos elementos que compõem o espaço, esse levantamento se faz ainda mais importante, pois, sua compreensão e entendimento refletirão diretamente na aplicação prática da cor no ambiente hospitalar. Usar desse conhecimento a favor do espaço é somente um começo para compreender a complexa rede de interação do homem com o meio ambiente e a necessidade de suprir as carências e anseios que o ser humano busca em suas relações ambientais, espaciais e sociais.

\subsubsection{As Influências das Cores na Percepção das Formas}

A cor pode ser um fator que altera, perceptivamente, as características de um edifício ou de um espaço interno. Conforme a finalidade, o uso da cor pode intensificar, modificar, ocultar e/ou falsificar a percepção das formas e, portanto, do espaço. A percepção das dimensões, do volume, e da própria perspectiva são aspectos que também sofrem influências das cores. Independente do conceito em que se usa a cor, na arquitetura, possui características de aplicação a serem consideradas para seu uso.

A cor pode influenciar na percepção dos aspectos acima citados. Por exemplo, determinados elementos podem se unificar ou se diferenciar através da seleção de um tom particular, da quantidade de um matiz, da variedade de matizes e /ou do grau de contraste, pois como cita Smith (2004, p. 163, tradução nossa): "[...] é também conveniente notar que determinadas cores têm qualidades espaciais que se diferenciam de outras [...]".

Dependendo do nível de contraste, os aspectos do campo visual são afetados, pode parecer se mover para frente ou recuar, pode expandir ou contrair. Outra relação importante para compreender como as cores afetam a percepção espacial, é levantada por Vera Pallamin (1991), ela salienta que a percepção sensorial estrutura-se, na relação figura-fundo, a qual se distingue intrinsecamente. Para ela, a figura possui atributos capazes de se descrever, como a solidez, sua colocação, no espaço e sua forma, características essas que estão ausentes no fundo. Anter (2000, 2008), Smith (2004) e Green-Armytage (2009) também ressaltam o papel da cor na relação figura-fundo para a percepção das cores. 
A cor percebida da figura sofre influência das cores de seu entorno e do fundo; para melhorar a qualidade visual da figura, de forma a dar mais segurança e nitidez ao observador, segundo Michel (1995), é favorável o uso de variações dos atributos da cor, sendo fundamental para criar tal distinção. "[...] para que os objetos possam ser tão facilmente vistos quanto possível, o sistema visual funciona de tal maneira que o contraste entre a figura e o fundo é reforçado [...]" (GREEN- ARMYTAGE, 2009, tradução nossa). Entretanto, como é ressaltado por Billger e Anter (2006) e Rasmussen (1974), a identificação e a percepção dependem da experiência do homem, sendo esse fator uma das principais características da experiência visual, assunto já amplamente discutido anteriormente.

Em um edifício ou espaço interno, a aplicação das cores pode variar, sendo mais ou menos indicada uma determinada composição, conforme o seu uso. Porém, seja um hospital, uma escola ou a parede de um quarto, a aparência das cores é percebida dentro de alguns conceitos e fundamentos que influenciam a percepção das cores e do espaço, e serão abaixo explicados.

\subsection{ATRIBUTOS DE APARÊNCIA DAS CORES}

Até o momento foram apresentados vários conceitos acerca da cor e, para complementar essa visão global do tema se faz necessário apontar uma distinção vital, que se refere aos conceitos que circundam a cor psicofísica e a cor inerente ${ }^{8}$, de um objeto ou superfície, para que fiquem claras as questões que envolvem a percepção da cor. Para Green-Armytage (2009), existe uma diferença fundamental entre os dois conceitos, pois cada um consiste em um aspecto da cor.

Segundo ele, a cor psicofísica é aquela que pode ser identificada por meio de um instrumento de medição, resultando em uma amostra padronizada, que pode compor um Atlas ou catálogo de cores; a cor inerente é aquela que é identificada por comparação visual entre as superfícies, colocadas em justaposição, nessa última entram as variantes do espaço, e que afetam a percepção cromática.

$\mathrm{Na}$ atualidade, um dos centros mundiais de estudos de aplicação da cor na arquitetura, com ênfase na questão da percepção cromática, é a Suécia,

\footnotetext{
${ }^{8}$ Termo usado por Kain Fridell Anter para distinguir a cor percebida daquela designada por um Atlas de cor. (ANTER, 2000).
} 
apresentando um vasto número de pesquisas e ampla produção literária e científica; destacam-se as pesquisas realizadas por de Mônica Billger, Karin Fridell Anter, Anders Liljefors, Maud Harleman, e Jan Janssens além de Instituições como a Swedish Colour Centre Foundation.

A aparência que a cor tem é fruto da percepção cromática, portanto, como visto, está relacionada com a interpretação individual, tendo uma aparência diferente cada um, Anter (2000, p. 46, tradução nossa) menciona: "[...] a importância do indivíduo e da situação de visualização [...] cada cor que vemos em uma determinada situação é, em grande medida dependente de nossos próprios fins, ao observar isso - o que estamos procurando? [...]".

[...] uma fachada vista ao longe poderá aparentar menos escurecida de que sua cor inerente; como, em um quarto amarelado sua cor será percebida mais saturada quando iluminado com a luz solar direta de que outro quarto, com a mesma coloração iluminado com luz solar indireta. (ANTER, 2000).

Ainda, segundo Anter, se junta ao item mencionado anteriormente, que ela denomina como referências do observador, intenções e atitudes, mais dois aspectos de fundamental relevância para a percepção: o das qualidades da superfície, que consiste na capacidade de cada superfície refletir diferentes comprimentos de onda de radiação, que é afetada pelo brilho e textura da superfície e pelo padrão de sombras criadas por meio da interação entre as diferentes formas, e o segundo aspecto é o das condições de visualização: “[...] a percepção das cores é influenciada pela intensidade, ângulo e composição da iluminação, pela distância da visualização e pelo ângulo de observação, pelas cores do entorno e por outros fatores que variam de acordo com a situação" (ANTER, 2000, p. 40, tradução nossa).

Os fatores descritos por Anter são utilizados para análises e estudos em suas pesquisas sobre a percepção das cores em fachadas, no entanto, claramente esses aspectos poderiam ser utilizados para os estudos da percepção das cores em ambientes internos. Na figura 32, Anter (2000) faz uma representação desses fatores de influência na percepção das cores. 


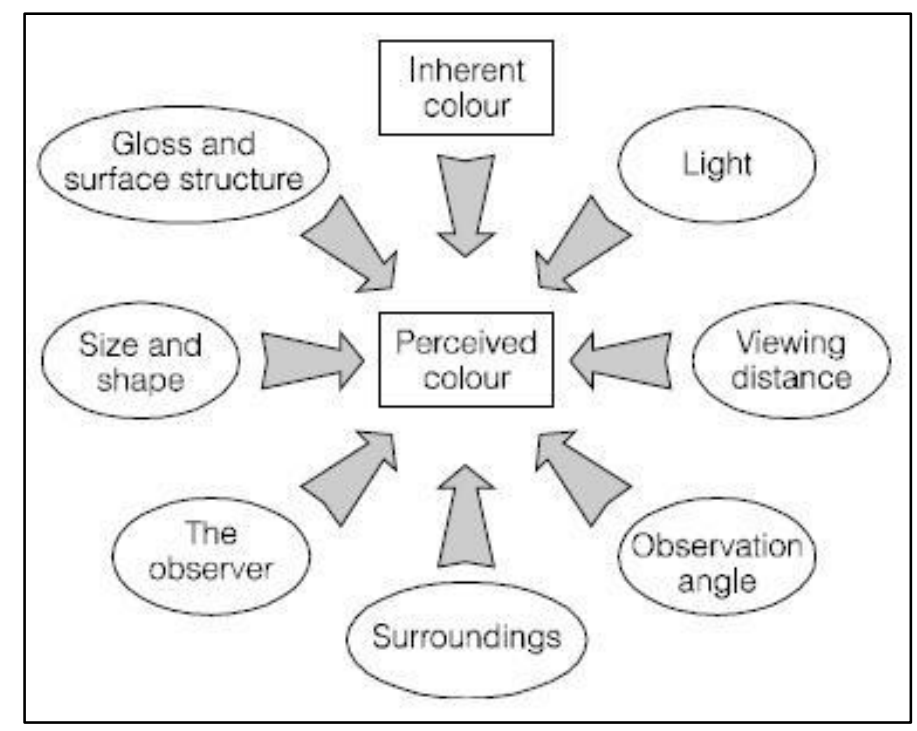

Figura 32 - Fatores de influência na percepção das cores.

Fonte: ANTER, 2000

Fora essa iniciativa, outros se dedicaram ao tema com destaque, entre os quais, Lois Swirnnof, com trabalhos importantes sobre o uso das cores na cidade e nos ambientes construídos. Também merece destaque a produção literária de Galen Minah, em um de seus papers, ela desenvolve um conceitos e diretrizes, para o uso das cores, nas etapas de concepção do projeto, desde os esquemas representativos até o detalhamento e ambientação.

Vale ainda ressaltar a sua visão do termo Colour Imagery (cor imaginária), nesse conceito está estabelecida uma relação de percepção da cor por meio da experiência da arquitetura, ou seja, a percepção desse espaço com suas cores:

[...] esta [colour imagery] carrega a materialidade, contexto físico, contexto cultural, simbolismo e resposta emocional, como também está relacionada com as metas conceituais e com a definição da forma [...] os estudos dessas questões servem como fundamento para as decisões da escolha das cores na fase de desenvolvimento do projeto [...] (MINAH, 2008, p. 5, tradução nossa).

O uso da cor, na arquitetura, deve ser baseado, segundo Billger e Anter (2006, p. 70), na relação entre dois aspectos da cor: Um é a cor percebida, variando, na real situação de espaço e, o outro aspecto é a questão de constância da cor na superfície, ou seja, saber como a cor inerente e a psicofísica aparecem no espaço.

Para a aplicação, da cor no espaço real, os estudos que focam suas pesquisas na percepção de uma parede e não, na totalidade do espaço, não devem ser guias para 
embasar a aplicação, na prática arquitetônica, que envolve sempre um contexto e um espaço mais complexo.

Para Billger (2004), o fato de a cor percebida de uma determinada superfície ou material apresentar uma gama de variedades sob diversas condições mostra a elasticidade que ela tem e, que para Arnheim (1995, p. 351), o termo usado para descrever tal característica é instabilidade, que se relaciona, "ao fato de que a mesma parte da cor em duas totalidades diferentes não são a mesma coisa [...] a mesma cor em dois contextos diferentes não é a mesma cor".

Na passagem, a seguir, fica clara essa instabilidade a que Arnheim se refere:

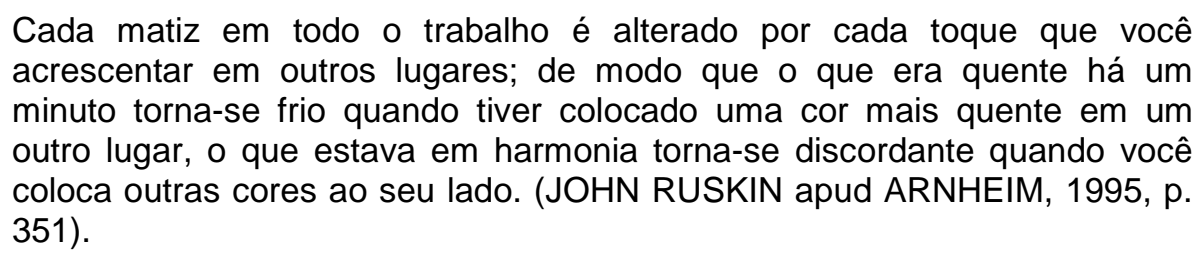

Portanto, com o intuito de ampliar o conhecimento sobre o uso da cor, na arquitetura, e suas consequências, na percepção espacial, serão apresentados, nos parágrafos abaixo, alguns dos atributos de aparência das cores, considerando a sua relevância para a arquitetura e posteriormente para o ambiente hospitalar.

\subsubsection{Textura e Material}

Para Anter (2000), o que determina a aparência de uma cor é a própria cor, as variantes da cor, decorrentes dos efeitos de luz e sombra, e as cores refletidas de outros corpos; para Dianne Smith (2004), a aparência de cor é afetada pela cor inerente do material usado ou pelas cores aplicadas sobre a superfície. Para Lou Michel (1995), a variação de aparência de cor das superfícies deve-se às propriedades físicas dos materiais, as quais mudam a cor da luz refletida de suas superfícies.

Pode-se constatar que as propriedades das superfícies, textura e material estão entre os principais fatores que afetam a percepção das cores, sobretudo quando a luz recai sobre elas; juntamente com o brilho e a dimensão das superfícies 
representam os principais aspectos que influenciam, na percepção das cores e em sua aparência.

Para muitos (MICHEL, 1995; BAKER, 2002; BERNS, 2000; HOSSOTTI, 1985), a textura e a refletância são os reais problemas que o arquiteto deve enfrentar ao usar a cor na arquitetura. As considerações sobre essas propriedades para o design se fazem fundamentais, ainda mesmo, na fase de concepção de um projeto.

O grau de refletância de um objeto está diretamente relacionado às propriedades de sua superfície, tais como textura, material e, até mesmo, a cor; uma superfície lisa mais irá refletir; já um material rugoso terá mais pontos de sombras e um efeito mais escuro, e conforme menciona Berns (2000), nessa questão está implícito o conceito de luminância, que será apresentado posteriormente, mas que tem grande influência para as questões cromáticas no design dos espaços interiores.

A relação da textura com a iluminação é direta e inseparável. Para Baker (2002), o mesmo ocorre com a relação entre textura e brilho, que acompanham um ao outro, estando suas percepções correlacionadas. O uso de cores e contrastes, nos materiais e texturas, conforme consideram Dalke, Littlefair e Loe (2004), podem criar superfícies com qualidades táteis, tornando o ambiente visualmente estimulante, e se usando de recursos de iluminação, podem maximizar os detalhes de sombra.

Michel (1995, p. 40, tradução nossa) exemplifica essas relações: "A superfície com textura traz ricos contrastes de luzes e sombras, e o relativo tamanho e densidade das unidades aumentam ou diminuem o brilho [...]".

Na figura abaixo, o uso da textura criada a partir do elemento madeira em sua cor natural cria um padrão visual dinâmico e cromaticamente interessante por meio de um jogo de sombras. A composição proporciona ao espaço uma variedade de estímulos, principalmente pela variedade de texturas (carpete, forro e paredes). 

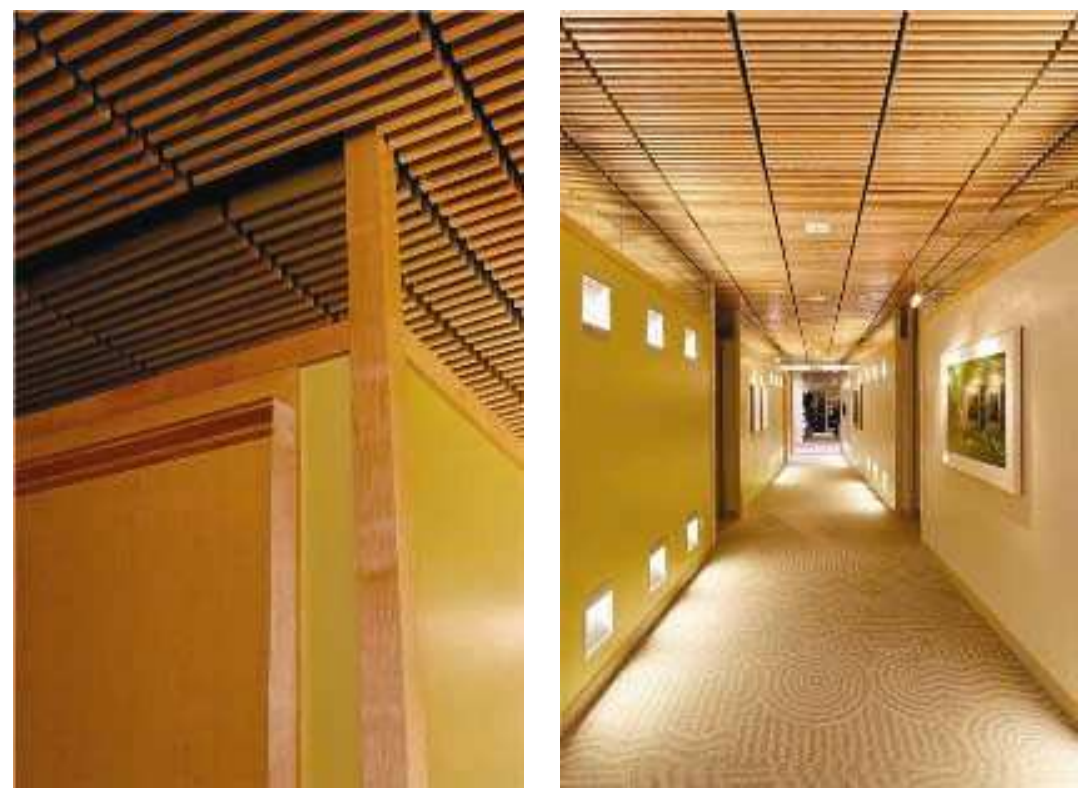

Figura 33 - Cisco LifeConnections Health Center, California. Fonte: www.jainmalkin.com.

Não somente as características do material e da textura das superfícies afetam a percepção cromática final de um ambiente, mas também, as relações entre elas podem alterar suas características de aparência. Elas interferem umas às outras. Das interferências entre as superfícies, Billger (2004) aponta alguns possíveis relacionamentos e eventuais consequências:

1. As superfícies coloridas dos objetos afetam a luz e a atmosfera de um ambiente, na figura abaixo, o piso azul expande sua refletância para paredes e piso, também a diferenças de textura e contraste, faz com que o painel salte à vista, ressaltando a perspectiva;

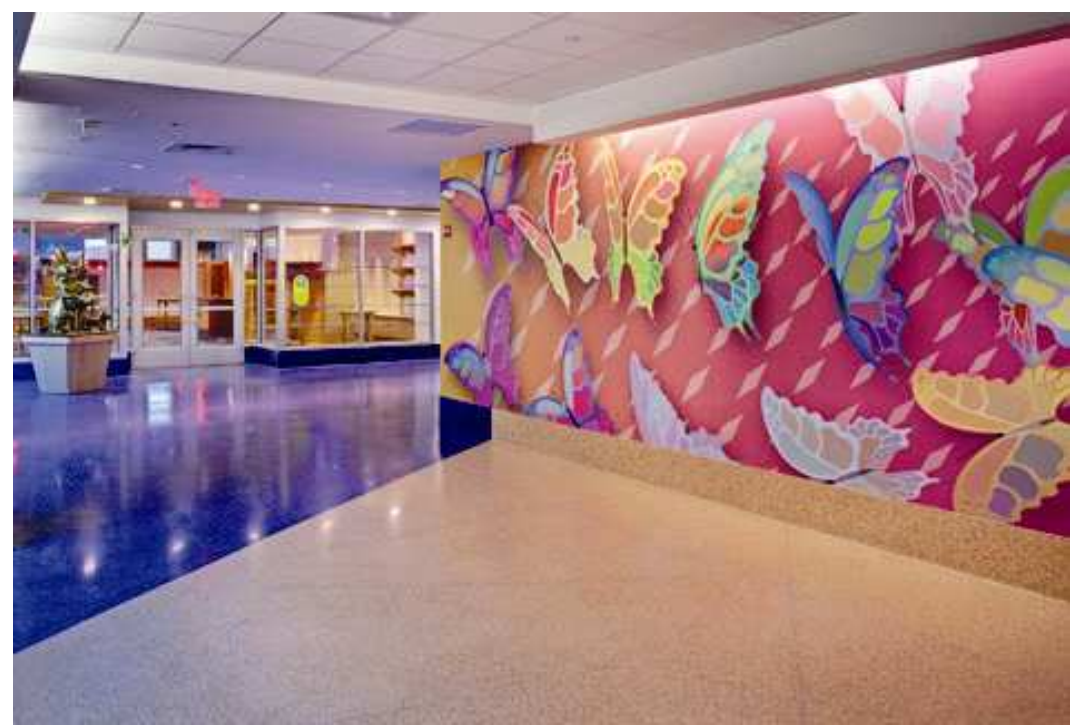

Figura 34 - Children's Hospital of Pittsburgh of UPMC. Fonte: www.wbdg.org/resources/therapeutic.php 
2. As reflexões de uma superfície sobre outra alteram as percepções dessas;

3. Os efeitos de diferentes posicionamentos das superfícies, no ambiente, variam a percepção.

Seus estudos (BILLGER, 2004), sobre a influência de uma superfície sobre outra, revelaram algumas indicações. O contraste mais claro das cores aparece, no centro, e os cantos das superfícies coloridas tornam-se mais similares quando refletidas uma contra a outra.

Nos cantos, a diferença de cor é nivelada quando se usa cores complementares, que ao se reunirem, aniquilam-se mutuamente. O mesmo acontece quando são utilizadas duas nuances diferentes da mesma cor, no entanto, quando se utilizam as mesmas nuances de dois tons diferentes, mas adjacentes, a aparência do ambiente como um todo se torna igual.

As superfícies, dependendo do tipo de material, cor ou ainda, posicionamento no ambiente, podem afetar consideravelmente a qualidade do conforto visual. $\mathrm{O}$ aço, materiais ou cores metálicas e o vidro são materiais amplamente utilizados, nos edifícios hospitalares, desde os elementos da arquitetura como também em equipamentos, mobiliários e acessórios, no entanto, as características desses materiais podem criar complicações para a percepção visual, como o ofuscamento e contrastes intensos; talvez um dos maiores problemas do design no ambiente hospitalar.

Materiais, cores e formas que minimizem os impactos das reflexões, clarões, ofuscamento e transparências, na percepção visual dos usuários, são apontados por Dalke, Littlefair e Loe (2004) como os que devem ser amplamente utilizados.

Para eles, pode-se obter um ambiente harmônico e confortável, por exemplo, compondo variados materiais e cores de menores índices de refletância (Figura $35 \mathrm{e}$ 36) e aplicando materiais e cores em formas diferenciadas que evitem os problemas apresentados anteriormente. 


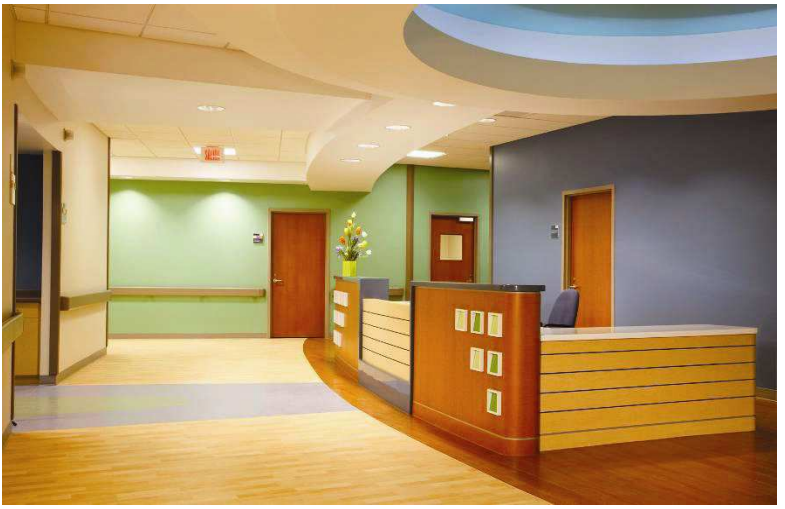

Figura 35 - Children's Hospital of Pittsburgh of UPMC. Fonte: www.chp.edu/CHP/Home.

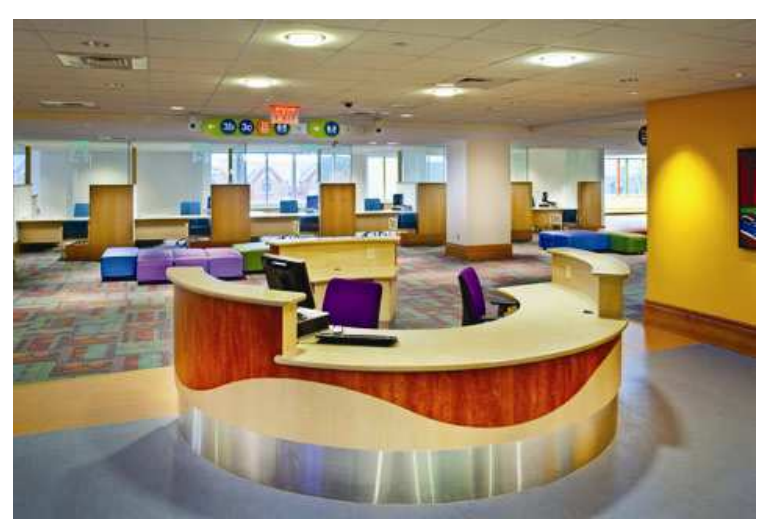

Figura 36 - American British Cowdray Women's and Children's Center, Cidade do México. Fonte: $36^{\circ}$ World Hospital Congress, 2009.

Os reflexos das cores e dos materiais do piso, das paredes e do teto afetam a cor da luz percebida. Como pode ser visto, na figura 37, o uso de películas coloridas nos vidros externos da fachada, criam reflexos em todo 0 ambiente interno proporcionando uma experiência visual, espacial, dinâmica, também proporcionada pela forma da edificação. Com relação aos reflexos das cores dos materiais das superfícies e dos objetos no ambiente, Guzowski (1999) discute amplamente o tema, no livro Daylighting for Sustainable Designs, que será aprofundado no item 5.3.3, que aborda o assunto da lluminação.
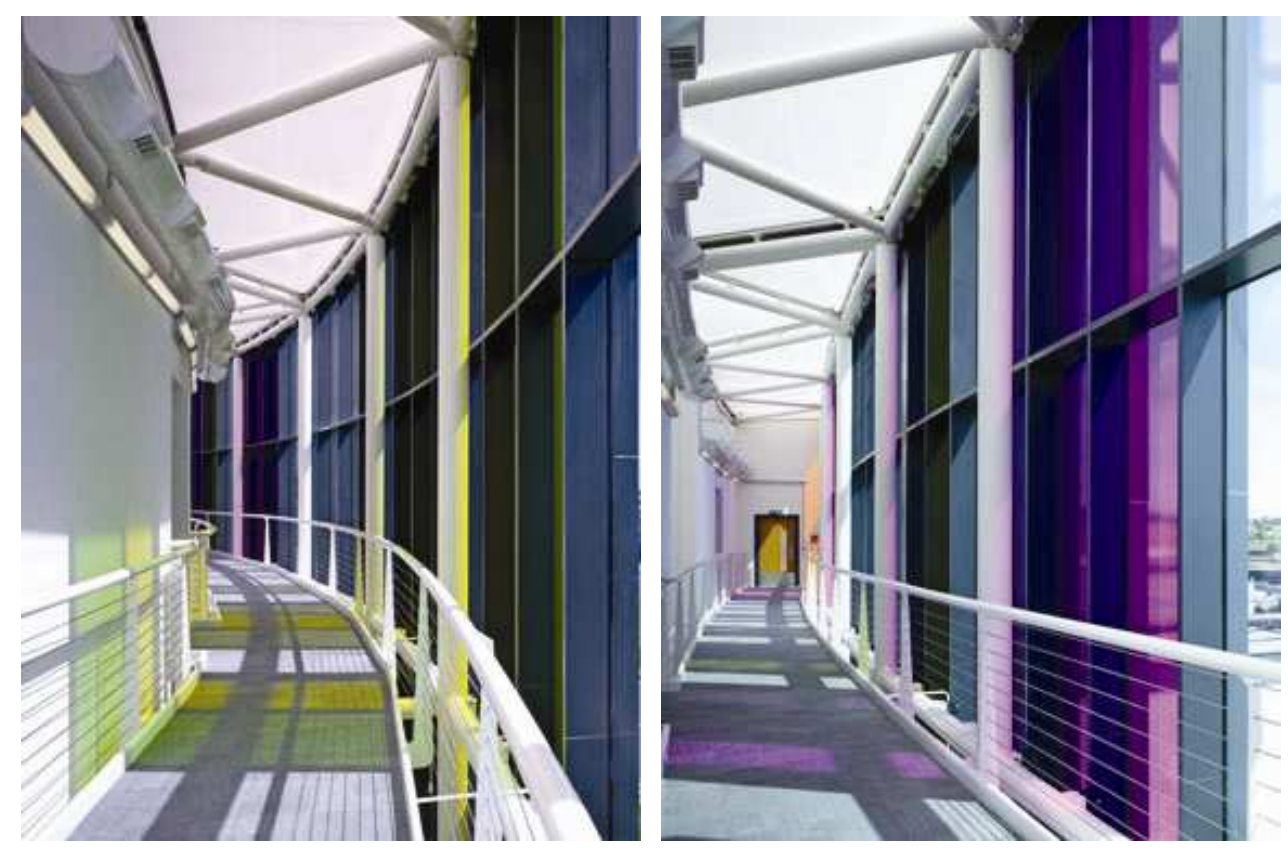

Figura 37 - King's Mill Acute Care Hospital PFI, Reino Unido. Fonte: www.shca.com. 


\subsubsection{Dimensão}

Conforme as cores usadas, a experiência do espaço como a impressão de altura, largura ou profundidade podem alterar a percepção dessas impressões, afirmam Mahnke e Mahnke (1996) e Billger (2004). A cor do piso e do teto alteram a aparência de altura, enquanto as cores das paredes podem provocar a sensação de abertura ou fechamento do ambiente; essas constatações foram obtidas por meio de pesquisas empíricas desenvolvida por Monica Billger com estudantes de arquitetura da Universidade de Chalmers.

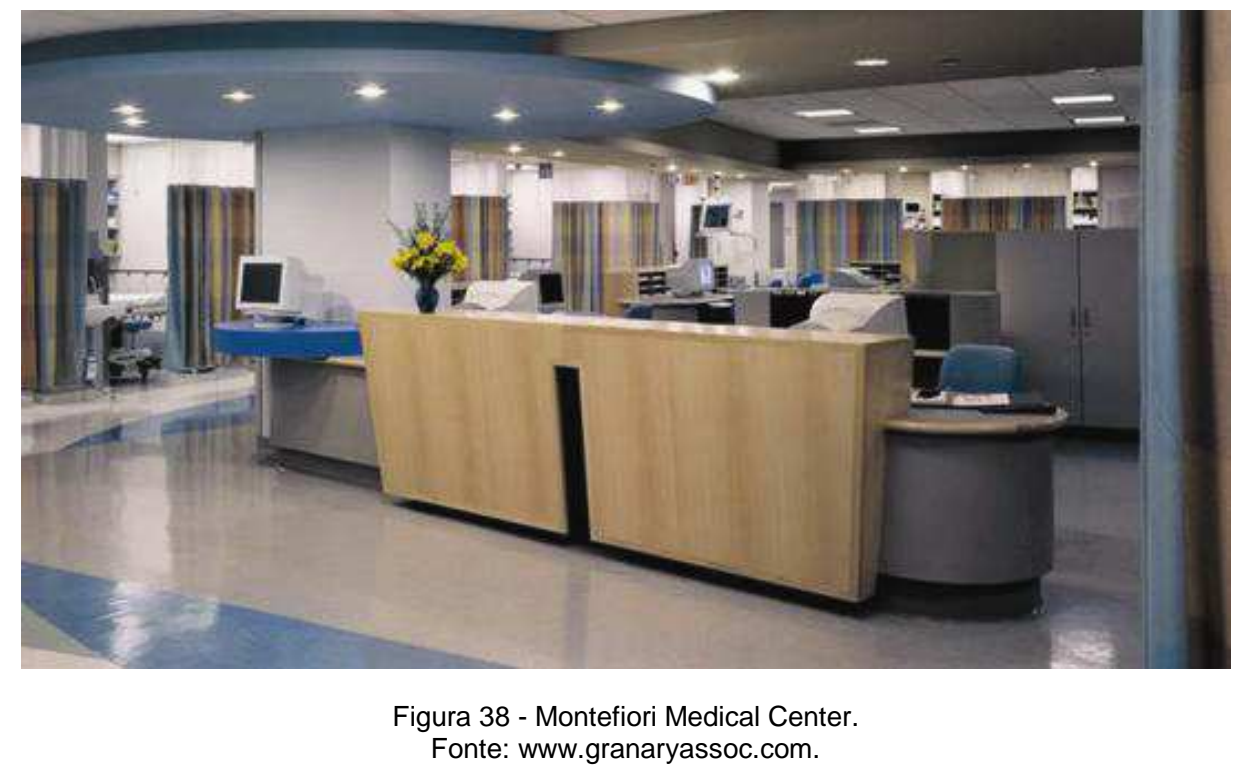

Na figura acima (Figura 38), o uso da cor azul cria uma sensação que abaixa o teto, criando pontos de interesse visual no teto, e proporcionando uma sensação de acolhimento na UTI adulto.

Para a percepção de amplitude do espaço interno, Malkin (1982) ressalta que um dos mais importantes fatores que influenciam essa percepção é a luminosidade da cor; uma cor pálida ou com baixa luminosidade aumenta o tamanho aparente de um ambiente, essas mesmas propriedades ocorrem com cores de curto comprimento de onda e padrões pequenos. As cores mais saturadas e de longo comprimento de onda, vermelhos, amarelos e laranja diminuem o tamanho e volume aparente de um ambiente, ocorrendo o mesmo com os padrões grandes. 


\subsection{3 lluminação}

O papel da iluminação, no ambiente hospitalar, é de extrema importância por inúmeros aspectos, inclusive para a aparência e percepção das cores. Lois Swirnoff (2003) considera que a iluminação é um dos aspectos que mais influenciam as variações de aparência das cores, segundo ela, conforme o grau de incidência da luz solar, que varia ao longo do dia, que recai sobre os objetos pode causar variações, nas intensidades dos matizes, deixando as superfícies com mais ou menos brilho.

A influência da iluminação nas cores vem sendo analisada por Anter (2000, 2008), com especial enfoque em fachadas, que concluiu que duas faces de uma fachada com a mesma cor inerente podem parecer diferentes, uma da outra, quando vistas em diferentes contextos, especialmente sob diferentes condições de iluminação.

Duas paredes de um edifício, que se encontram em um canto e são pintadas com a mesma tinta, e possuem a mesma cor inerente, não terão a mesma aparência de cor, se uma possui uma iluminação direta da luz do sol, e a outra está, na sombra. $O$ mesmo ocorre, quando se compara uma mesma cor em diferentes escalas de aplicação. Uma cor, estando em uma amostra de um Atlas de cor, não terá a mesma aparência quando for pintada em uma parede, as cores quando comparadas entre si não pareceram ser a mesma cor.

Os estudos de Billger (2004) sobre as influências da iluminação para a aplicação das cores em ambientes internos revelaram que, se em um mesmo ambiente são usadas cores diferentes e com iluminações também diferentes pode-se obter uma cor semelhante entre elas. Por exemplo, em um dos experimentos, para a pintura de um quarto, foram usados dois matizes diferentes, usou-se um amarelo e um outro amarelo mais forte, notou-se que eles se tornavam iguais sob diversas condições de iluminação, primeiramente iluminado por luz natural e, posteriormente por uma luz incandescente; as mesmas cores ficaram completamente semelhantes quando a cor mais forte foi iluminada por uma luz azulada e a cor mais leve por uma luz amarelada.

Os índices de iluminação também podem alterar a aparência de volume; quanto mais iluminação, ou maiores os índices de iluminação, mais a aparência de volume 
tende a aumentar e, do contrário, a baixa iluminação diminui o volume aparente, salientam Mahnke e Mahnke (1996).

Os experimentos de Billger (2004) revelaram que é possível criar uma sala com aparência quente em uma situação em que se utiliza uma luz fria ou escura, que pode ser alcançada, usando campos em vermelho no piso, em uma sala com paredes acinzentada; outro exemplo, é que, em dias de frio, ao se utilizar azuis intensos, em uma sala, a sensação gerada é de vivacidade, no entanto, essa combinação não obtém o mesmo resultado sob lâmpadas incandescentes.

Na situação acima citada, a melhor combinação, para se obter um sentimento de vivacidade, é utilizar nas paredes um matiz vermelho, saturado. Portanto, a pesquisa concluiu que, em ambientes que se deseja criar sentimentos de vivacidade, deve-se variar a sombra de cores através de uma composição de branco com uma outra cor contrastante.

Outro aspecto encontrado é que sob a luz do sol, a cor amarela pode tornar-se menos luminosa e as cores azuis, sob lâmpadas incandescentes, tornam-se mais escuras, o contrário do que ocorre ao serem iluminadas pela luz do sol, tornam-se mais vivas. A cor verde, no entanto, aparenta da mesma forma, mais viva, sob ambas as luzes, do sol e incandescente.

A luz refletida das cores, dos materiais e das superfícies pode ser descrita por características de sensação ou aparência, percebida pelo observador como sombria, morna, fria, saturada, etc. Juntamente com a reflexão das cores das superfícies, o tipo de iluminação ambiental existente irá compor o resultado final.

A literatura mostra que se deve fazer uma avaliação dos níveis de luz natural e da qualidade da iluminação artificial, a qual indicará as paredes que são mais sombreadas e, que, portanto, poderão receber cores mais luminosas, aquelas que refletem mais luz e vice-versa. Battistella (2003, p.41) expõe: "A claridade nesses ambientes é determinada não apenas pela intensidade da luz, mas também pelas distâncias e pelos índices de reflexão das paredes, teto, piso, mobiliário e máquinas". Na figura 39, os pilares iluminados na parte superior, elevam o olhar, criando demarcações. A parede, na cor azul de média saturação e baixa luminosidade compõem, o ambiente, sem prejudicar o conforto visual. 


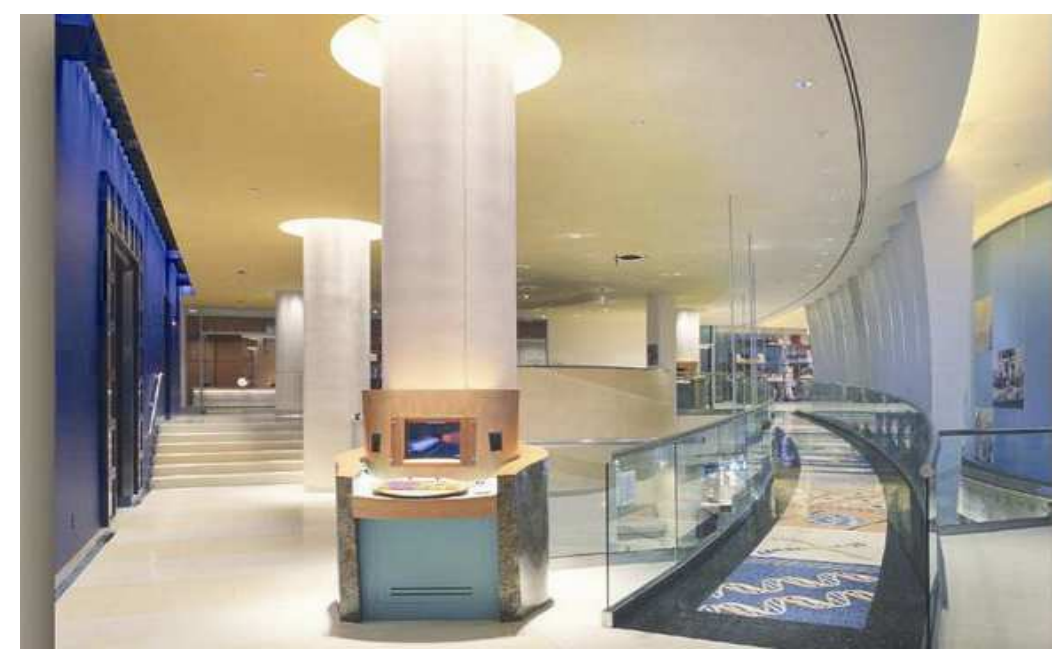

Figura 39 - Montefiori Medical Center. Fonte: www.granaryassoc.com.

$\mathrm{Na}$ figura 40, um exemplo diferenciado do emprego das cores, uso de vidros coloridos no corredor; as cores afetam umas às outras, composição valorizada pela iluminação natural produzindo um efeito lúdico.

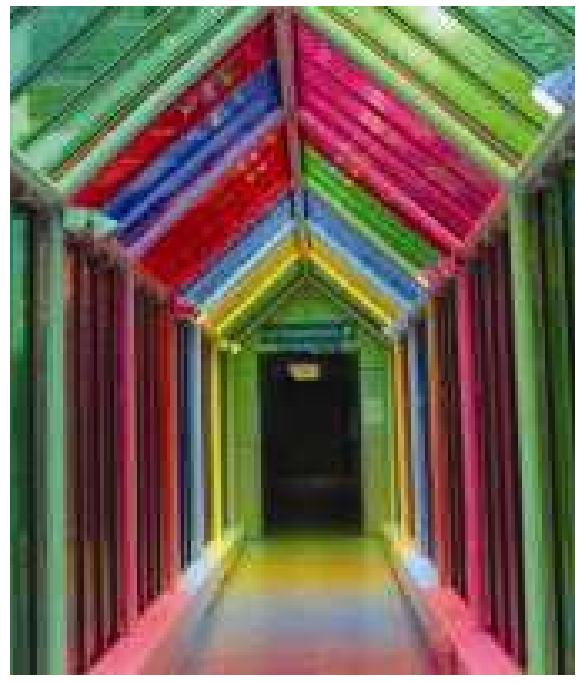

Figura 40 - Birmingham Children's Hospital. Fonte: www.granaryassoc.com.

Os elementos arquitetônicos, paredes, piso e teto devem compor uma combinação eficiente, visando ao conforto visual dos usuários; Grandjean e Kroemer (1997) ressaltam dois pontos fundamentais para a qualidade lumínica, do ponto de vista do conforto visual: O primeiro refere-se às superfícies do campo visual, as quais devem ter a mesma ordem de luminosidade. O segundo é que o índice de iluminação não deve ser alternado rapidamente, ou seja, a mudança, nos níveis de iluminação, deve ser gradativa para uma melhor adaptação visual. 
Além dos aspectos levantados por Grandjean e Kroemer, outro aspecto essencial são os níveis de reflexão das superfícies. O nível de reflexão é formado pela somatória dos níveis de reflexão das cores e materiais, do campo visual; na Tabela 1, são apresentados os graus ideais de reflexão de cada superfície, para se obter o melhor conforto visual.

Tabela 1 - Graus de reflexão das superfícies ideais para o conforto visual.

\begin{tabular}{ll}
\hline SUPERFÍCIES & REFLEXÃO EM PORCENTAGEM (\%) \\
\hline TETO & 80 a $90 \%$ \\
PAREDES & 40 a $60 \%$ \\
MÓVEIS & 25 a $45 \%$ \\
MÁQUINAS E APARELHOS & 30 a $50 \%$ \\
PISOS & 20 a $40 \%$ \\
\hline
\end{tabular}

Fonte: Cunha, 2004, p. 59.

Um estudo notou que a luz parecia em menor quantidade mas, mais intensa quando as paredes eram pintadas com cores escuras; na figura 41, o uso de lâmpadas fluorescentes difusa evita o ofuscamento nas superfícies lisas e se contrapõe com os tons escuros. Um amarelo, frequentemente, está relacionado às cores quentes, mas em determinadas situações como em dias de sol pode ter uma aparência mais próxima das cores frias. Algumas cores podem ficar mais vivas quando são iluminadas por uma luz com predominância da mesma cor que a luz da superfície iluminada (BILLGER, 2004).

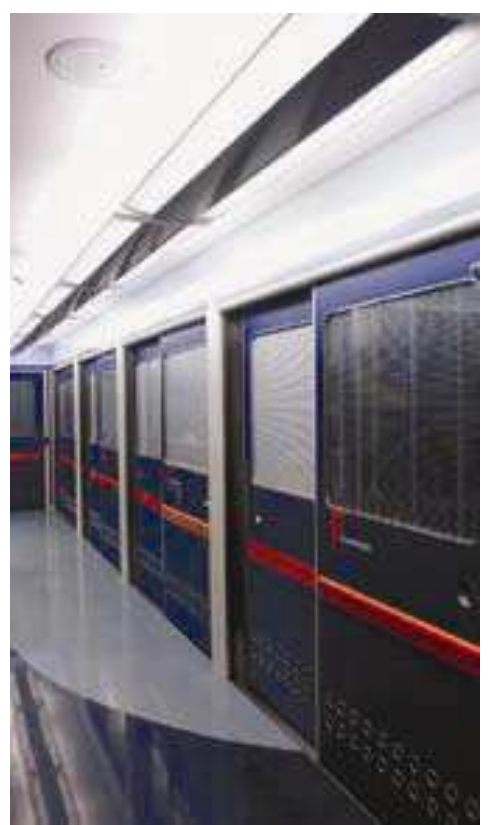

Figura 41 - Hospital Paulistano, São Paulo. Fonte: Grunow, 2002.

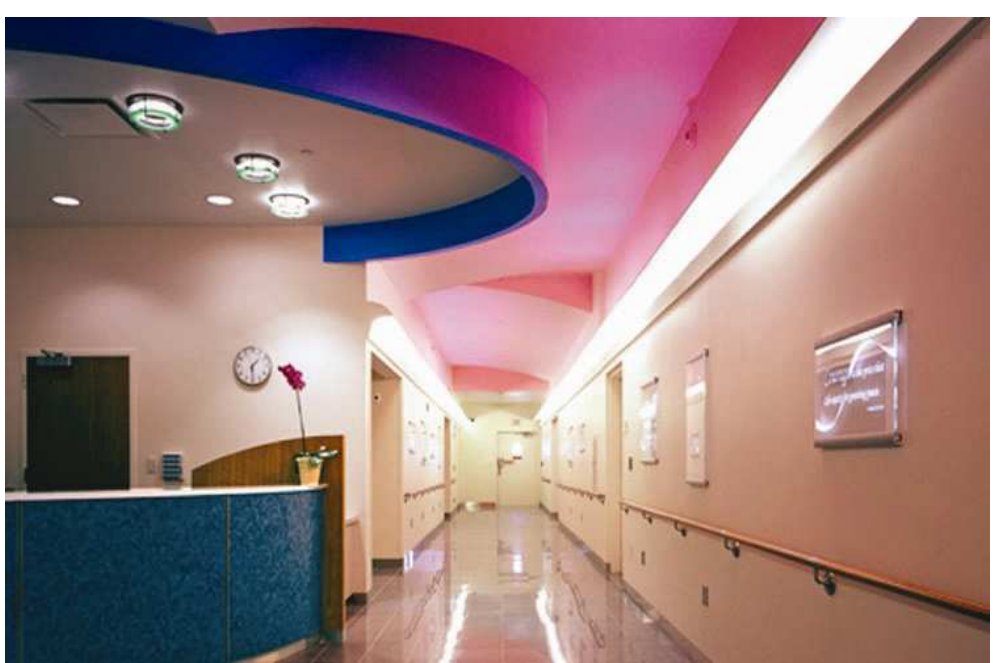

Figura 42 - California-Pacific-Medical-Center. Fonte: www.cpmc.com. 
Como mostrado, as reflexões luminosas das cores interagem entre si e, com a iluminação do ambiente (Figura 42). Portanto, os níveis de reflexão das cores desempenham grande importância, na aparência final do ambiente, inclusive podendo ser um aliado da iluminação artificial e natural de um ambiente; a interação busca melhorar os níveis de iluminação e manter o equilíbrio do ambiente e, mesmo, da iluminação.

Na figura 42, o uso de luz colorida interage com as cores do ambiente e serve como iluminação noturna para definir circulação e guiar orientação, criando um destaque à composição cromática mais neutra do corredor.

$\mathrm{Na}$ Tabela 2 são apresentadas algumas referências de cores e de materiais com seus respectivos índices de reflexão; esses índices servem para juntamente com os índices de iluminação, artificial e natural, compor o aspecto lumínico de um ambiente. Esse aspecto refere-se a um conceito da iluminação que possui grande relevância para a aplicação de cores nos ambiente internos. O conceito de luminância é considerado, por muitos como, um dos principais aspectos para a composição cromática e, juntamente, com o conceito de iluminância compõem aspectos básicos para o design de interiores, aponta Michel (1995).

Tabela 2 - Graus de reflexão em percentual do fluxo luminoso incidente.

\section{COR E MATERIAIS}

BRANCO

ALUMÍNIO

MARFIM, AMARELO LIMÃO FORTE

AMARELO FORTE, OCRE CLARO, VERDE CLARO, AZUL PASTEL, ROSA CLARO, "TONS CREME"

VERDE LIMÃO, CINZA CLARO, ROSA, LARANJA FORTE, CINZA AZULADO

MADEIRA CLARA, AZUL CELESTE

CONCRETO SECO

VERMELHO FORTE, VERDE GRAMA, MADEIRA, VERDE OLIVA, MARROM

AZUL ESCURO, VERMELHO PÚRPURA, CASTANHO, CINZA

ARDÓSIA, MARROM ESCURO

PRETO
REFLEXÃO EM PORCENTAGEM (\%)

100

80-85

$70-75$

$60-65$

$50-55$

40-45

30-35

20-15

$10-15$

0

Fonte: BATTISTELLA, 2003, p. 42. 
No ambiente hospitalar, ocorre muito comumente de se terem espaços iluminados somente por iluminação artificial, que possui características específicas; outro fator específico do ambiente hospitalar é a presença de grande quantidade de material e equipamento com acabamentos e cores metálicas. Isso torna o aspecto ambiental muito suscetível ao sentimento de frieza, insegurança e desamparo, conforme apontam Nelson, West e Goodman (2005), Malkin (1982) salienta que é devido a esse fato que se indica a utilização de materiais e cores que aqueçam o ambiente, que remetam à vivacidade e às cores quentes.

\subsubsection{Iluminância e Luminância}

"Primeiro, não é o nível de iluminação que conta; de fato, o que nós percebemos e o que nos ajuda a 'ver' é a luminância" (GRANDJEAN; KROEMER, 1997, p. 299, tradução nossa).

Os conceitos mais importantes para a aparência e percepção da cor, segundo Michel (1995), referem-se aos termos: iluminância e luminância da luz. Muitos designers consideram a luminância a mais importante para a variação cromática. A compreensão de seus conceitos esclarece a propriedade de como essas características podem afetar a percepção cromática de forma tão intensa.

Por iluminância, Berns (2000) entende como a energia da luz que chega a uma determinada superfície emitida por uma fonte, com um determinado valor; esse valor é mensurável e sua unidade é a candela (cd). Os índices de iluminância seguem à lei do quadrado ao inverso; se a fonte está ao dobro da distância do objeto a porcentagem de luz que chega e atinge o objeto é na razão de $25 \%$ ou fator 4 ; conforme uma fonte de luz é distanciada ou aproximada de um objeto percebe-se, claramente, a mudança no brilho da superfície do objeto. Para Michel (1995), essa é uma das mais importantes características da iluminação para a sua aplicação no design.

A luz refletida, que aparece em uma superfície, ou seja, aquela vista pelo olho, é denominada luminância, refere-se à luz que deixa a superfície depois de ser refletida; essa propriedade somente existe quando a superfície é iluminada, portanto, para Berns (2000), é uma propriedade intrinsecamente visual. Ela depende 
da qualidade refletida do material da superfície e da quantia de iluminância que recebe e, diferentemente da iluminância, a luminância não é afetada pela mudança de distâncias entre a luz da superfície e o observador.

Um dos problemas para a aplicação das cores, nos ambientes internos, é considerado por Fonseca (2000) o entendimento das seguintes diferenças: a cor da iluminação das superfícies em que as luzes refletem, e da percepção da cor na retina. Cada superfície apresenta propriedades distintas frente à incidência do fluxo luminoso; as cores claras, em paredes e teto, contribuem com as reflexões, aumentando o nível de iluminação do ambiente, à medida que materiais de alta refletância expostos à iluminação natural provocam excessiva iluminância.

Desse modo, nota-se que a qualidade da aparência das cores está diretamente relacionada com a boa distribuição de iluminâncias, ausência de ofuscamento, proporção de luminâncias e um equilibrado padrão de sombras, todos os aspectos relacionados à iluminação. Portanto, no processo de projetação de uma composição cromática, para determinado ambiente, avaliar e considerar o projeto de iluminação é princípio básico para a obtenção da qualidade do projeto.

\subsubsection{Brilho}

Outra relação existente, quanto às variações de aparência no dimensionamento de um ambiente, é apresentada por Lou Michel (1995). Ele relaciona a distância aparente e o brilho de um matiz, e estabelece que nessa relação os objetos coloridos brilhantes aparecem mais perto do olho. A relação de brilho é direta com a iluminação, mas sua aparência muito depende dos atributos de cor:

\footnotetext{
Qual superfície colorida é mais brilhante, a vermelha ou a verde? A informação que falta, nessa questão, é a luminosidade e a saturação das cores, depende de qual vermelho ou verde que vem à mente, quando a questão é perguntada. Se o vermelho e o verde tiverem a mesma luminosidade e saturação, então estará correto se você responder que elas aparecem sobre o mesmo brilho. (MICHEL, 1995, p. 92, tradução nossa).
}

No aspecto levantado por Michel, vale salientar que o que determina maior ou menor brilho de uma cor, além da própria cor, é a iluminação utilizada no ambiente. Por brilho, entende-se, segundo Michel (1995, p. 12, tradução nossa), como: "[...] impressão subjetiva da luz que ilumina uma superfície comparada com outra [...]", 
William Lam (1986) acrescenta que essa relação é baseada em referenciais dependendo das interpretações de cada um. Portanto, brilho é o contraste percebido das luminâncias.

O brilho das superfícies também altera noções espaciais, como mencionado anteriormente e é um dos fatores que mais pode prejudicar o conforto visual. A noção de brilho é afetada por fenômenos como os contrastes simultâneos. Outros conceitos também envolvem a percepção de brilho nas superfícies. Os olhos, em um processo involuntário, vão se adaptando e respondendo a mudanças que ocorrem, principalmente com relação aos valores de brilho, esse processo recebe o nome de adaptação de luz, no entanto, quando as mudanças acarretam variações também nas cores percebidas, o processo se chama adaptação cromática (BERNS, 2000). Portanto, visando ao conforto visual, as mudanças devem ser graduais para não causar o ofuscamento, assim, os contrastes excessivos não são recomendados, tampouco, contrastes sucessivos em um mesmo ambiente.

Na figura abaixo, a composição é elaborada com cores saturadas, de variedades de matizes e luminosidades, com iluminação dispersa e texturas diversificadas. A composição apresenta pontos de brilho que se equilibram e se destacam sem causar desconforto visual.

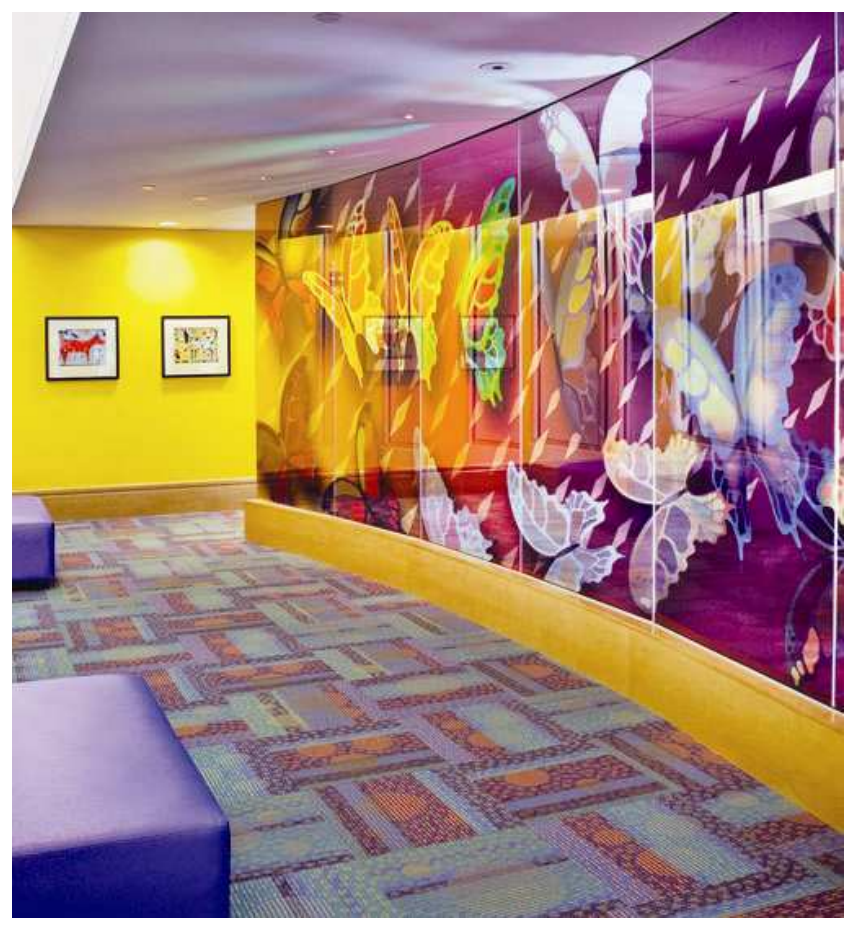

Figura 43 - Children's Hospital of Pittsburgh of UPMC. Fonte: www.chp.edu/CHP/Home. 
$\mathrm{Na}$ figura 44, a cor predominante é a azul de baixa luminosidade e índice de reflexão, e a iluminação utilizada é difusa, no entanto, os dois ambientes apresentam altos índices de reflexão, o brilho excessivo decorrente dos materiais das superfícies causa desconforto visual. A composição da luz "de temperatura fria" com as cores cria uma sensação de frieza, mesmo contrapondo-se com os detalhes de cores quentes.
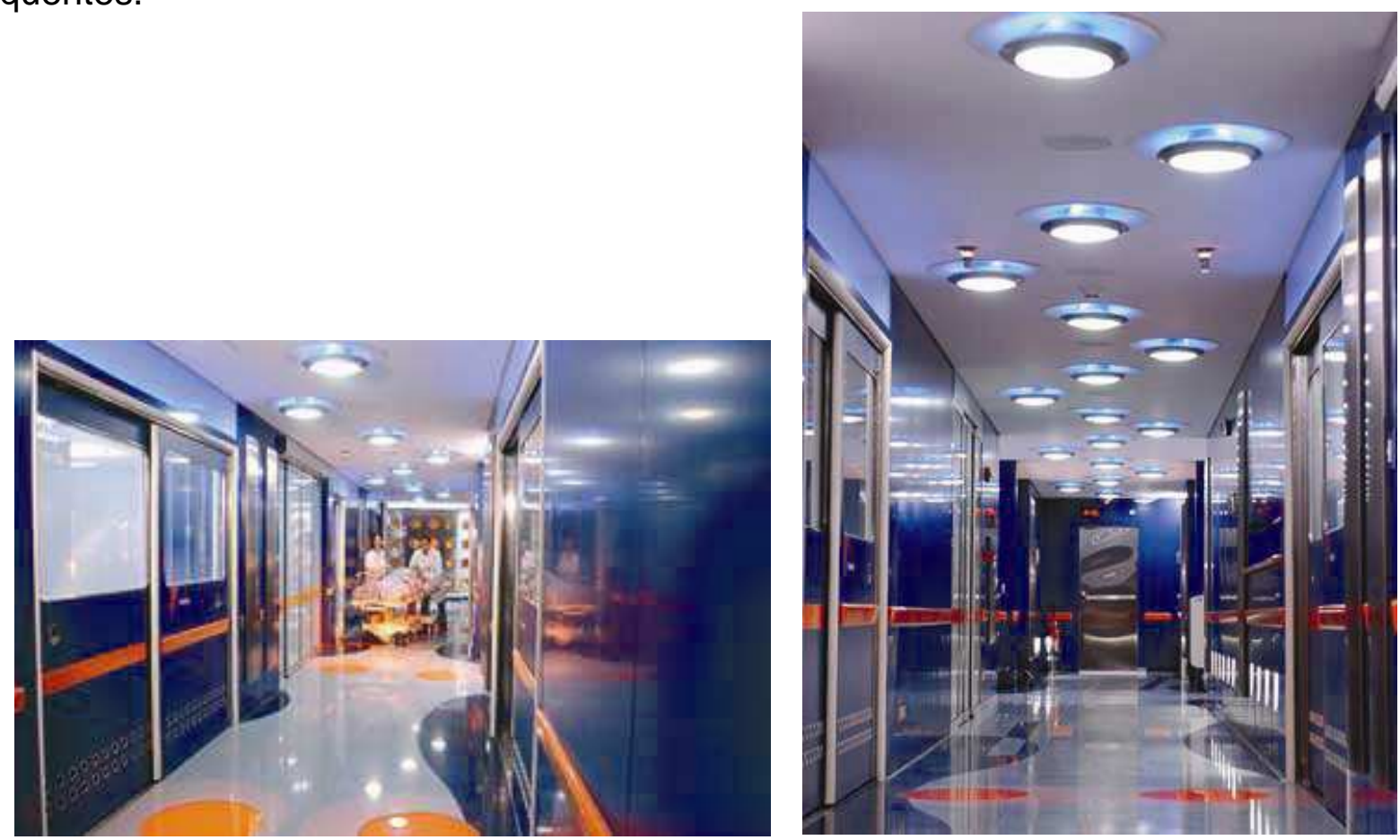

Figura 44 - Corredores Emergência, Hospital Paulistano, São Paulo. Fonte: Grunow, 2002.

No Capítulo Sete, que se dedica à aplicação prática das cores no ambiente hospitalar, o atributo brilho será novamente abordado, com um maior aprofundamento de suas implicações à percepção cromática e, como o uso adequado desse atributo pode auxiliar positivamente para a experiência visual e espacial no ambiente hospitalar.

Embasando-se em Mahnke (1996), pode-se considerar que a experiência visual para o corpo clínico poderá ser positiva se, entre outros aspectos, as questões relacionadas ao desenvolvimento das atividades e ao desempenho dos serviços forem contempladas, proporcionando precisão visual. Assim como para os pacientes a experiência visual poderá ser enriquecedora, ao se buscar, na composição cromática, e nos atributos de percepção da cor, suporte para os aspectos emocionais, preservando o bem-estar psicológico. 


\subsubsection{Constância de Cor}

"[...] podemos perceber as cores, no nosso meio ambiente, como relativamente constante, mesmo se a situação de luz mudar drasticamente [...]" (ANTER, 2000, p. 28, tradução nossa).

O fenômeno acima descrito pode ser chamado de constância de cor, e segundo Anter (2008), é necessário para a capacidade de identificação de um objeto, de imediato, independentemente da ocorrência de iluminação.

No entanto, torna-se difícil a manutenção da constância de cor usando diferentes fontes de iluminação. Quando as pessoas observam um espaço, a relação das características das cores parece permanecer estável, no entanto, ao se utilizar variedades de iluminação, a constância é prejudicada. Mas segundo Berns (2000), o olho possui a capacidade de compensar, em grande parte, as mudanças nos níveis e na cor da iluminação.

O espaço hospitalar dentre as suas peculiaridades possui ambientes em que não há iluminação natural, atualmente busca-se que todos os ambientes sejam beneficiados pela iluminação natural, mas nem sempre é possível. Ocorre que uns ambientes durante o dia, possuem iluminação natural e são complementados por iluminação artificial, à noite; conforme Dalke, Littlefair e Loe (2004) mencionam, as cores dos ambientes devem permanecer com características (atrativas, relaxantes, estimulantes,...) equivalentes em ambos os casos, tornando a seleção das cores ainda mais complexa e dificultosa, pois não é possível prever ou testar as cores nas diversas situações possíveis.

Eles citam, por exemplo, que alguns matizes "beges" ou composições neutras, assim como o matiz laranja, podem assumir características perceptivas sem atrativos sob tipos diferentes de iluminação. "[...] O que parece ser de dia uma composição suave, confortável e neutra pode tornar-se desagradável à noite [...]", assim, uma orientação é dada por eles: "[...] a superfície ideal para se colocar um matiz, de destaque, mais forte, é aquela que recebe luz plena de dia e, também, tem boas condições de iluminação noturna, assim não parecerá ser muito escuro" (DALKE; LITTLEFAIR; LOE, 2004, p. 53). 
Os assuntos abordados, nesse Capítulo, foram as principais características e os princípios fundamentais para a aplicação das cores na arquitetura, especificamente, em ambientes internos. O hospital, enquanto tipologia arquitetônica, possui características muito distintivas, requerendo situações cromáticas específicas; o embasamento sobre como se dá a percepção espacial e qual é o comportamento e características das cores, no ambiente, aprofundam o tema visando à aplicação prática no ambiente hospitalar; buscou-se, na apresentação, levantar algumas diretrizes particulares para o uso das cores no ambiente hospitalar e, que, posteriormente, no Capítulo Sete, serão retomadas. 
CAPÍTULO 6 A ARQUITETURA HOSPITALAR 


\section{CAPÍTULO 6}

\section{A ARQUITETURA HOSPITALAR}

\subsection{CONTEXTUALIZAÇÃO HISTÓRICA}

Dentre os campos do conhecimento, a arquitetura destaca-se com projetos e propostas inéditos. Entre suas especificidades, podem-se citar as inovações do ambiente hospitalar. Esta, por sua vez, conta, por meio da sua história, a história da evolução da humanidade, uma vez que sua evolução é concomitante com as evoluções e com as descobertas pelas quais passou a humanidade.

\subsubsection{Entendendo o Hospital Contemporâneo: Os Primórdios do Edifício Hospitalar}

As primeiras referências que se tem de locais onde abrigavam doentes é na Grécia Antiga. Hipócrates, considerado o Pai da Medicina, legou à medicina de então um caráter racional, pois nesse período, a medicina era mítico-religiosa. Segundo relatos antigos, existia, na Grécia anterior a Hipócrates, templos dedicados a Asclépio, semi-deus, venerado como pai da medicina da época. O mais famoso de todos era o templo de Epidauro. Nesses templos, os sacerdotes, denominados Asclepíades, eram os terapeutas (CATON, 1898; TOLEDO, 2002).

Até o aparecimento de Hipócrates, a cura estava estreitamente ligada à religião e à magia. Por meio de rituais, ora mais, ora menos agressivos, os procedimentos para o tratamento e cura das doenças transcendiam a barreira do real. À medida que a medicina hipocrática se desenvolveu, os templos de Asclépio (Figura 45) tornaramse verdadeiros estabelecimentos sanitários, com programas que estimulavam uma vida saudável, voltados para o bem-estar do corpo e da mente (NUTTON, 2004).

Há uma estela ${ }^{9}$, datada do séc. II d.C., cujo conteúdo é bem revelador das mudanças que, entretanto, tinham-se operado, no templo de Epidauro, o qual já não é apenas um local de peregrinação religiosa mas também um estabelecimento sanitário a par de um centro de lazer, cada vez mais mundano, com os seus banhos de águas quentes e frias, as suas pousadas, os seus ginásios, as suas corridas e os seus jogos, para além do

\footnotetext{
${ }^{9}$ Estelas (ou inscrições votivas) que foram descobertas por arqueólogos constituem hoje uma fonte de informação preciosa
} sobre o Templo de Epidauro e o culto de Asclépio (GRAÇA, 2000, p.113). 
seu famoso teatro, construído, no séc. IV a.C., e considerado o melhor e o mais belo da Antiguidade [...] Em suma, um verdadeiro programa de promoção de estilos de vida saudáveis. (GRAÇA, 2000, p.113, grifo do autor).

Entretanto, mesmo com essas características, percebe-se que as preocupações com a saúde do corpo e da mente estão muito mais ligadas à cultura grega que cultuava o corpo do que propriamente uma preocupação com a saúde pela saúde.

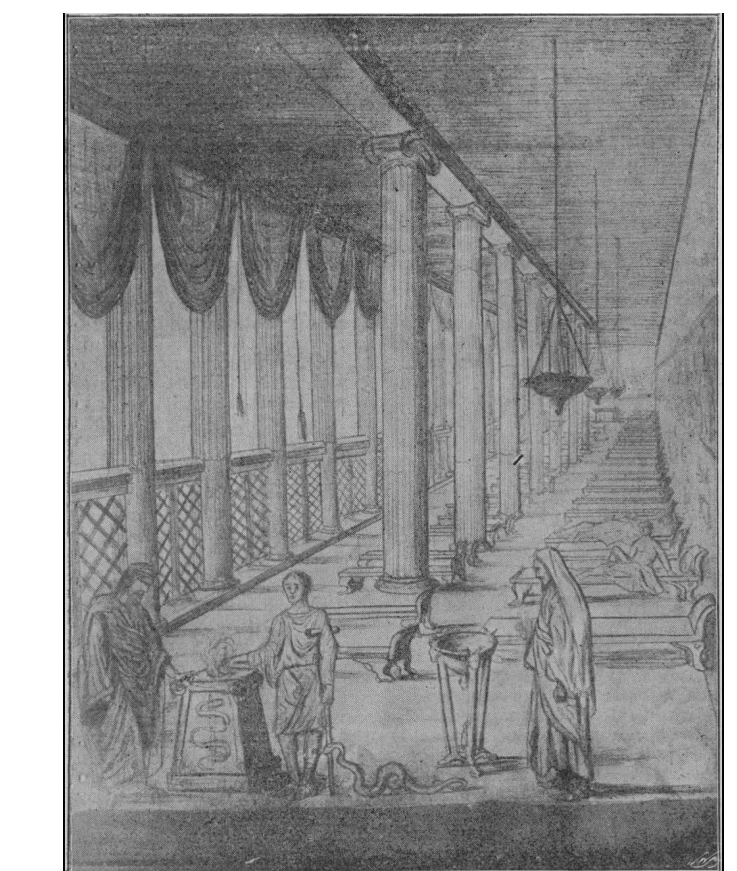

Figura 45 - Gravura da sala dos pacientes no templo de Asclépio. Fonte: CATON, 1989

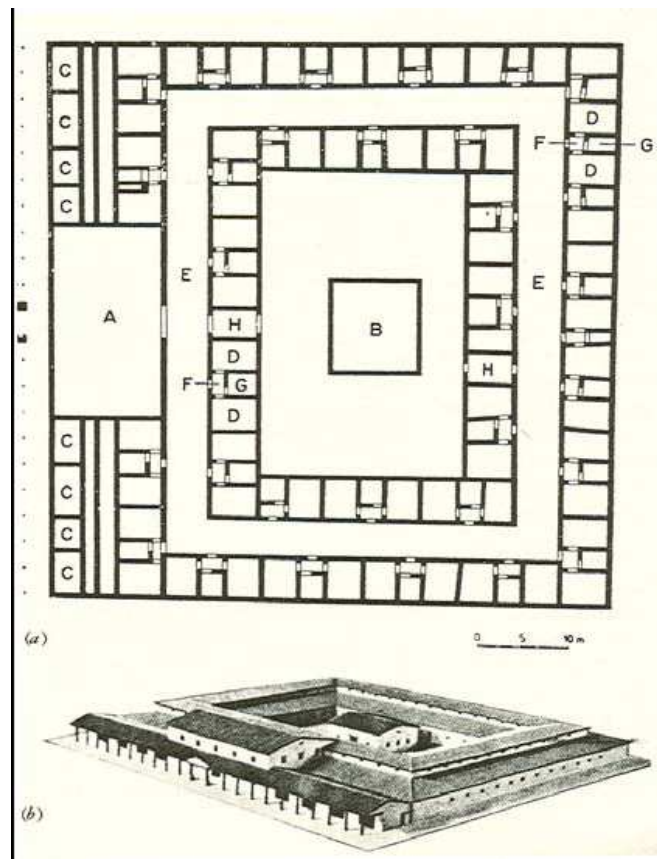

Figura 46 - Valetudinárias dos romanos. Fonte: BARACH; DICKERMAN, 2006.

Outros estudos referem-se às Valetudinárias dos romanos (Figura 46) como os primeiros hospitais conhecidos. Esses hospitais destinavam-se, especialmente, ao tratamento de doentes e feridos de guerra e apresentavam construções bem projetadas, de modo a favorecer com recursos de ventilação e iluminação todos os ambientes (NUTTON, 2004; DAVIES, 1970), conforme Lukiantchuki e Caram (2008, p. 3) constatam:

[...] através dessa tipologia tinham-se adequadas condições de iluminação e ventilação naturais dos espaços internos, uma vez que as Valetudinárias eram constituídas de elementos articulados em torno de um pátio central que assegurava para todos os quartos o contato com o exterior.

Há menção, na história, de que os hebreus, o Japão, a China e a Índia também desenvolveram uma forma de organização hospitalar, por vezes complexas. Mas, de modo geral, com exceção desses, os povos da antiguidade não despenderam 
maiores preocupações com os aspectos sanitários, quer da coletividade, quer das famílias ou indivíduos (LISBOA, 2002).

Na Idade Média (500 - 1450 d.C.), essas construções mudaram de caráter. Devido à crescente insalubridade, comum do período, e consequente propagação de doenças como, por exemplo, a peste negra que devastou a Europa, os hospitais passaram a ter uma função mais de isolamento do resto da população do que propriamente de cura.

Nesse sentido, surgiram por toda a Europa, no século VI, as chamadas Ordens Hospitalarias, e que tinham por missão a assistência aos enfermos, principalmente, aqueles assolados pela lepra (Figura 47); conforme aponta Lisboa (2002), somente na Alemanha, esses tipos de alojamentos foram construídos com o intuito de tratamento dos enfermos e não de isolamento, como os demais.

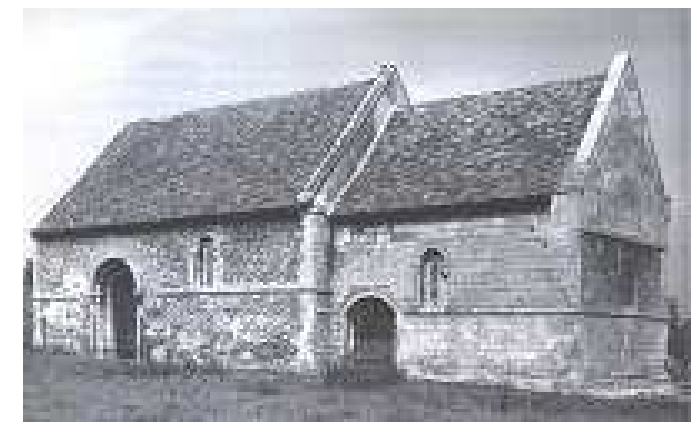

Figura 47 - Leprosário St Mary Magdale, Cambridge Fonte: www.buildinghistory.org/articles/heritagemercy.shtml.

De acordo com Graça (2000, p. 44, 87, 144), "[...] o hospital é uma criação da cristandade da Alta Idade Média. Etimologicamente a palavra hospital vem do baixo latim hospitale - local onde se recebem pessoas que precisam de cuidados, alojamento, hospedaria [...]", em contrapartida, Lisboa (2002) oferece outra constatação importante quanto ao termo, a palavra hospitium, que derivou hospício, e designava os estabelecimentos que eram ocupados permanentemente por enfermos pobres, incuráveis ou insanos, ao contrário daqueles que recebiam para tratamento temporário os doentes, estes eram denominadas hospital; cabe, aqui, ressaltar que essa terminologia tem a mesma concepção que a de atualmente; já a terminologia hotel, também usada para designar um local de assistência à saúde, recebia pessoas "não doentes". 
Portanto, como mencionou Graça (2000, p. 144), estando o hospital ligado à religiosidade (Figura 48 e 49), normalmente, as construções localizavam-se ao lado de igrejas e mosteiros, que se incumbiam de tal tarefa, destacando a importância da religião, presente na arquitetura:

[...] Não admira, por isso, que o hospital cristão medieval vá ser estruturado, até na sua própria arquitetura e na sua organização espaço-temporal, como a casa de Deus, um lugar onde, mais do que curar a doença, se cuida sobretudo da salvação da alma. Daí os primitivos hospitais em França adotarem a designação de Hôtel-Dieu, como o de Paris, fundado no Séc. VII (provavelmente por volta de 651), e considerado hoje o mais antigo dos hospitais existentes em todo o mundo.

Suas construções seguiam a mesma estrutura das catedrais medievais, com pouca ventilação, o que favorecia a disseminação de doenças, e pouca luminosidade, criando ambientes escuros e amedrontadores, completamente insalubres (Figura 48). Tais edificações refletiam, também, as características das estruturas góticas das catedrais, tais as paredes largas, semelhantes às prisões e fortificações.

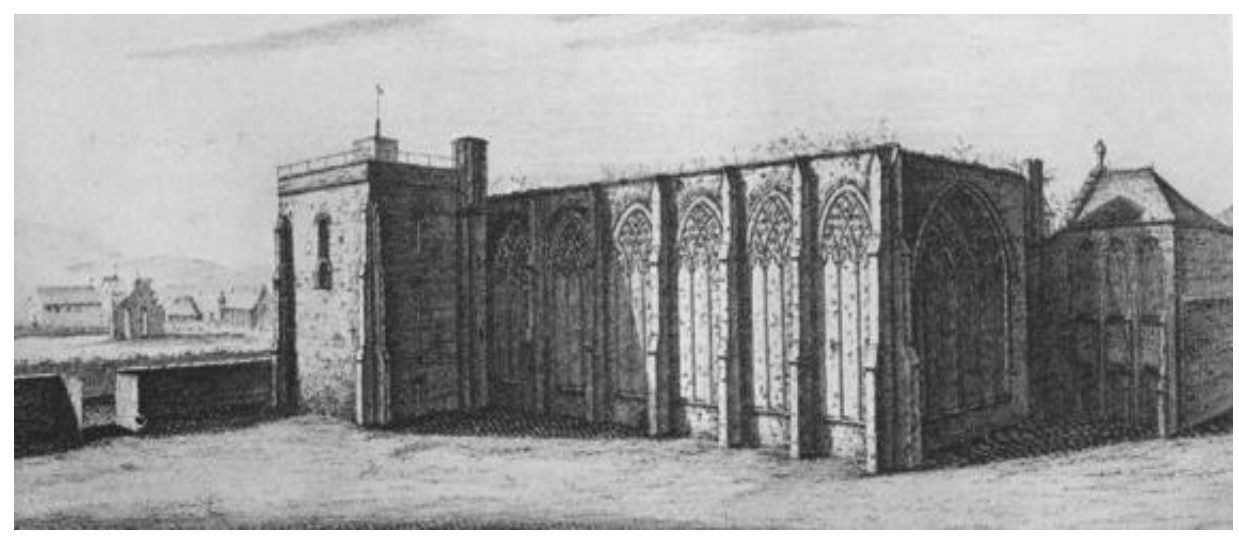

Figura 48 - St. Mary's Hospital, Dover, séc. XIII. Fonte: CLAY, 1909.

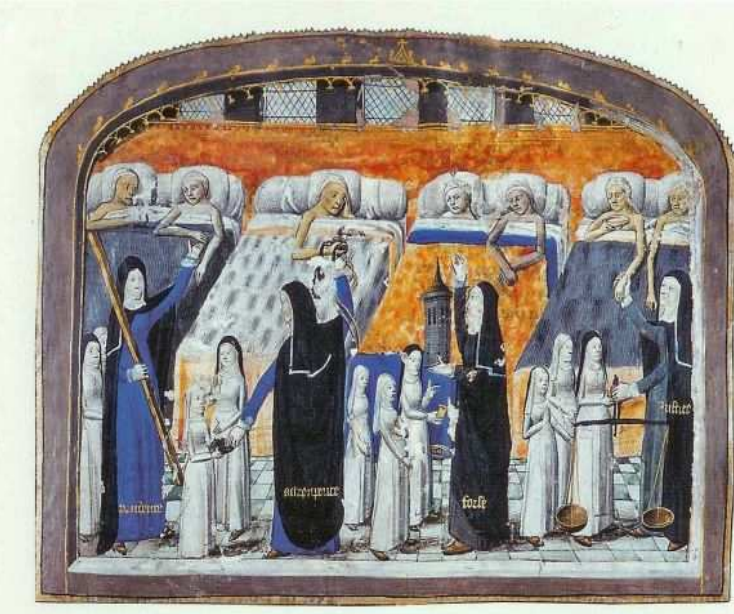

Figura 49 - Gravura de assistência aos doentes, Paris. Fonte: www.thegreathospital.co.uk. 
Com a pouca iluminação e ventilação natural, decorrentes de escassas janelas e aberturas, 0 ar era, nesses ambientes, um agente contaminante. Eram nessas condições que as pessoas doentes eram assistidas, as quais, em sua maioria, não retornavam, restando-Ihes a morte, por essas características, Costi (2002) salienta que as construções desse período eram denominadas Salle de Mourir.

No entanto, entre os séculos X e XII, constituem-se mudanças quanto à morfologia do edifício de assistência à saúde e que vão influenciar as construções posteriores; Com condições mais apropriadas das construções como as naves em abóbadas, que possibilitou vãos maiores, as iluminações e ventilações melhoraram significamente, tais constatações podem ser vistas nas figuras 50, 51 e 52.

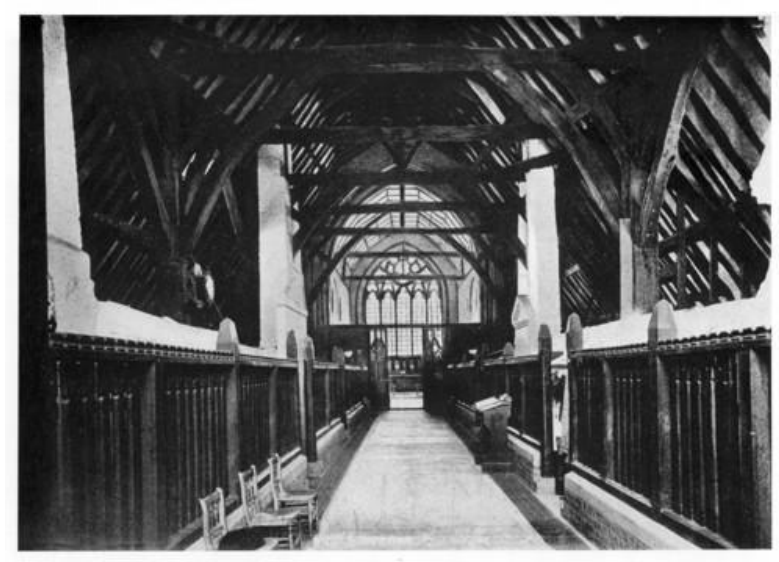

Figura 50 - St. MarysHospital. Sec XIII - Londres. Fonte: CLAY, 1909.
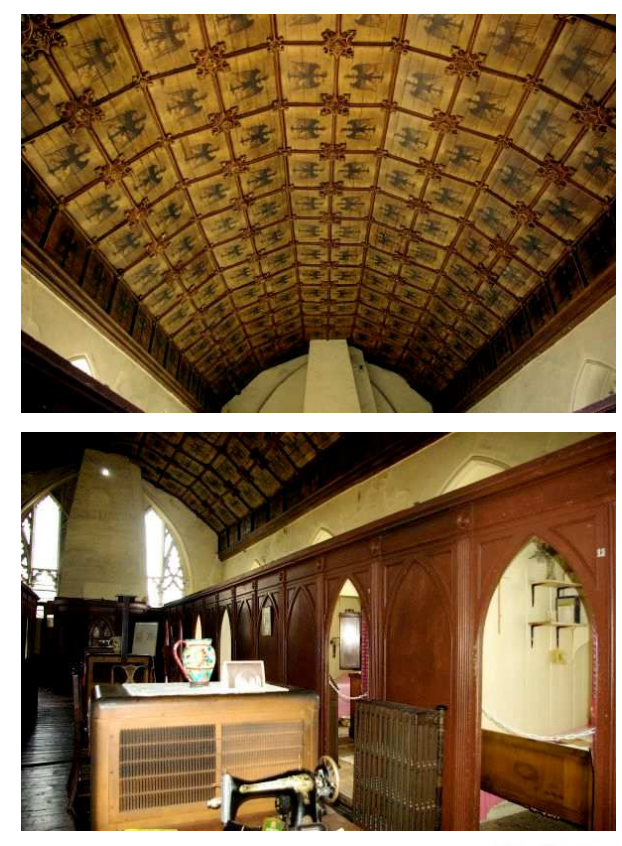

Figura 52 - Acima: Enfermaria e detalhe do teto. Ao lado: planta baixa, St Giles' hospital, Reino Unido, séc. XIII - XVI. Fonte: /www.thegreathospital.co.uk/,

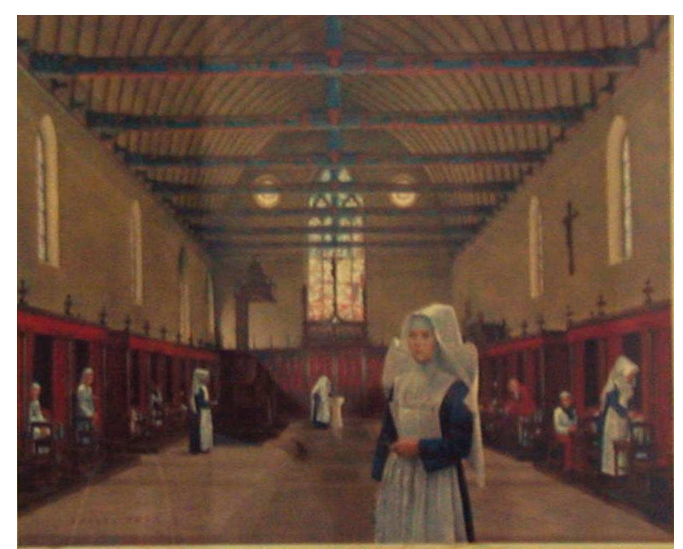

Figura 51 - Representação de hospital medieval, Hotel-Dieu de Beaune, France, sec. XV. Fonte: www.dodd.cmcvellore.ac.in/hom/10\%20$\% 20$ Medieval\%20Hospital.html.

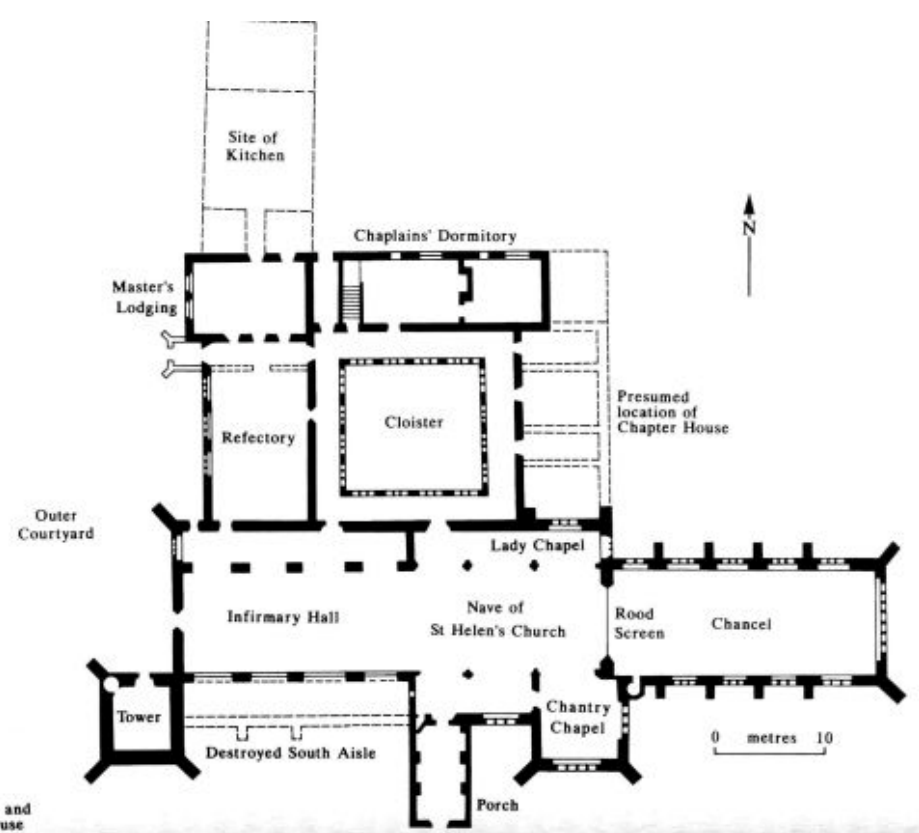

$$
\text { . }
$$


Com o surgimento das Universidades e o desenvolvimento de uma nova classe social, a burguesia, a partir do século XIII, começou a ocorrer algumas mudanças com relação aos cuidados com a saúde, embora, ainda assim, as instituições hospitalares continuaram nas mãos da Igreja.

Foi somente a partir do século $\mathrm{XV}$, com o movimento renascentista, que ocorrem as maiores mudanças até então. Com uma nova mentalidade, as ciências se impulsionaram, dando bases a novas descobertas, que se dão no campo da anatomia, da física, da matemática, da arte, enfim, em vários campos do conhecimento. O Renascimento provoca muitas transformações, que acabam por desenhar um outro movimento, o lluminismo, movimento este, que propunha uma nova maneira de pensar, um pensar mais racional.

Toledo $(2002,2005)$ salienta que é nesse panorama, com os adventos da Revolução Industrial e das Revoluções Burguesas, e as transformações técnico-científicas e sociais, as quais influenciaram todas as áreas do conhecimento, provocando uma reestruturação da sociedade, que ocorre uma notável transformação na arquitetura hospitalar. Vários autores concordam que a origem do hospital contemporâneo ocorreu, neste período, entre os séculos XVII e XVIII, tendo como marco a reconstrução do Hospital Hotel.-Dieu de Paris.

Esse projeto destaca-se por apresentar um partido inovador, para os padrões da época. Pela primeira vez, na arquitetura hospitalar, considera Silva (1999), foi delineado um projeto tendo como ponto central a funcionalidade. O projeto foi elaborado pelo médico, Jacques Tenon, após várias pesquisas e visitas a outros hospitais. Além disso, seus estudos constituíram-se de várias instruções e normas que puderam ser utilizadas por outros arquitetos (COSTI, 2002).

Antunes (apud SILVA, 1999) ressalta ainda um fato inédito, foi um projeto fruto da associação entre a experiência clínica de um médico e o destino das instituições hospitalares, colocando, assim, os médicos no topo da hierarquia técnica e administrativa dos hospitais contemporâneos. Para Foucault (1998), nasce o médico de hospital e a medicalização do hospital, pois este passa ser um espaço destinado exclusivamente ao tratamento de doenças, com organização administrativa e operacional. 
Esse projeto proposto por Tenon concretizava a organização pavilhonar horizontal do edifício hospitalar, solucionando o problema de ventilação e iluminação (SILVA, 1999), seu projeto não foi executado devido ao início da Revolução Francesa, mas serviu de modelo para outros hospitais construídos posteriormente. Nas figuras abaixo, exemplares das construções da tipologia pavilhonar horizontal.

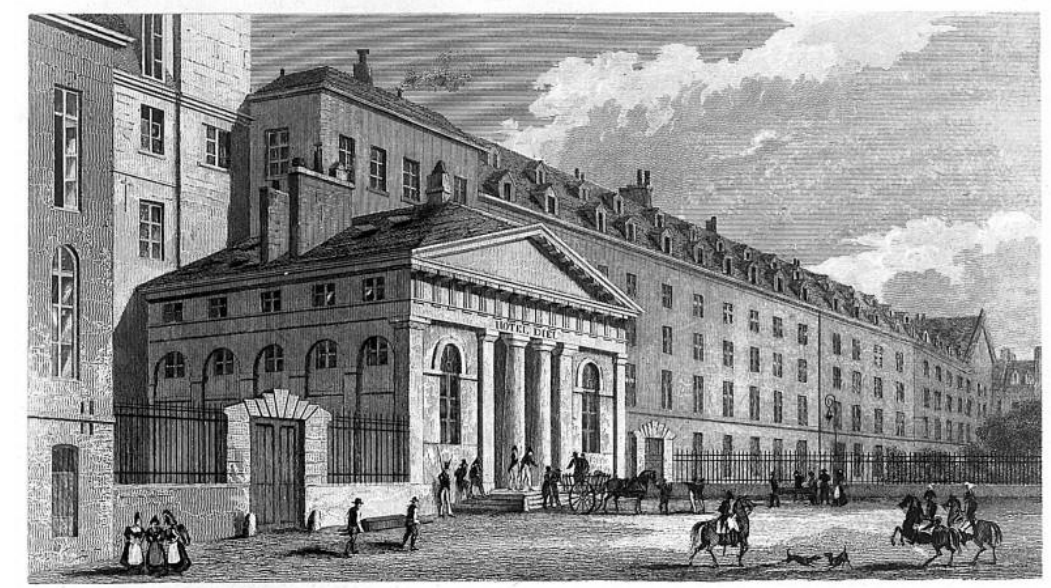

Figura 53 - Gravura Hotel Dieu, Paris, séc. XIX.

Fonte: U.S. National Library of Medicine.

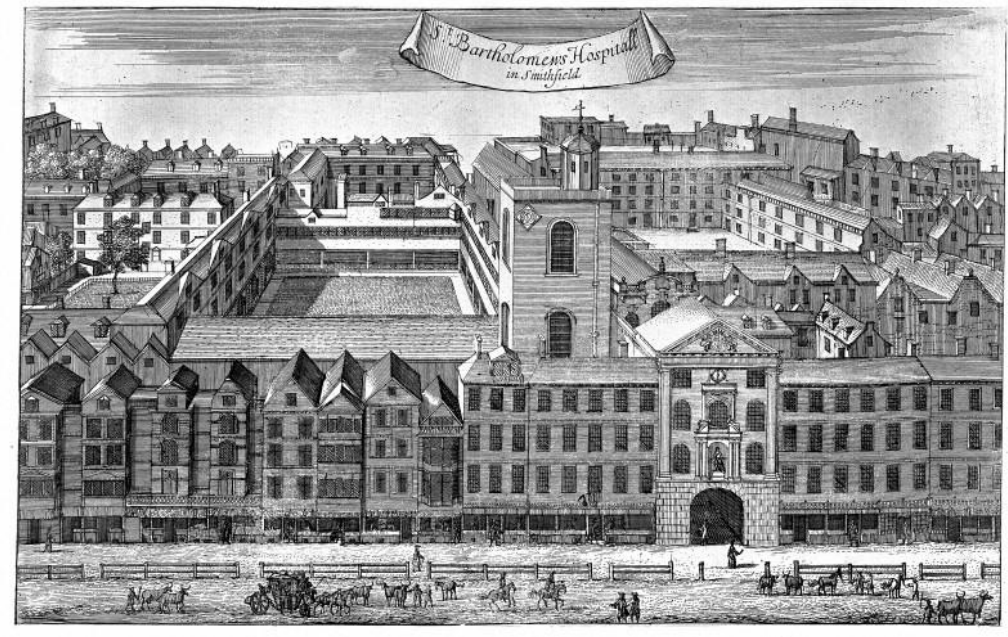

Figura 54 - St. Bartholomew's Hospital, Londres, séc. XVIII. Fonte: U.S. National Library of Medicine.

No séc. XIX, na Inglaterra, a enfermeira, Florence Nightingale, propõe transformações maiores ainda na concepção, provocando uma humanização ${ }^{10}$, com a criação das "enfermarias Nightingale", que foi chamada por Miquelim (1992) de modelo "pavilhonar-nightingale". As alterações proposta por Nightingale (1860) refletiam diretamente, na construção, favorecendo a iluminação e a ventilação natural; elementos fundamentais, segundo ela, para um ambiente saudável. Para

\footnotetext{
${ }^{10}$ O termo humanização, aqui utilizado, deve-se ao fato de as mudanças ocorrerem, substancialmente, na organização operacional e, na estrutura física do hospital, levando-se em considerações os aspectos humanos dos pacientes e, sobretudo, a busca pela qualidade de vida dos ocupantes daqueles espaços, sem, no entanto, diminuir ainda a importância do conforto ambiental; tais termos, de concepção contemporânea, podem ser aplicados aqui devido ao mesmo princípio ideológico.
} 
ela, a falta desses elementos era considerado como um dos motivos de proliferação e aprofundamento das doenças.

A "enfermaria Nightingale" consistia, basicamente, em um salão longo e estreito, com leitos dispostos, perpendicularmente, em relação às paredes perimetrais, com banheiros e cozinha bem ventilados dispostos nas extremidades (Figuras 55 e 56). Dentre as mudanças realizadas por Nightingale, Lukiantchuki e Caram (2008) apontam que estão a redução do pé-direto das salas, pois assim conseguia-se um maior controle da temperatura e a disposição, nas enfermarias, de janelas em ambos os lados, o que proporcionava ventilação cruzada, além de possibilitar a entrada da luz solar, promovendo ao ambiente uma outra sensação, sensação de vida.

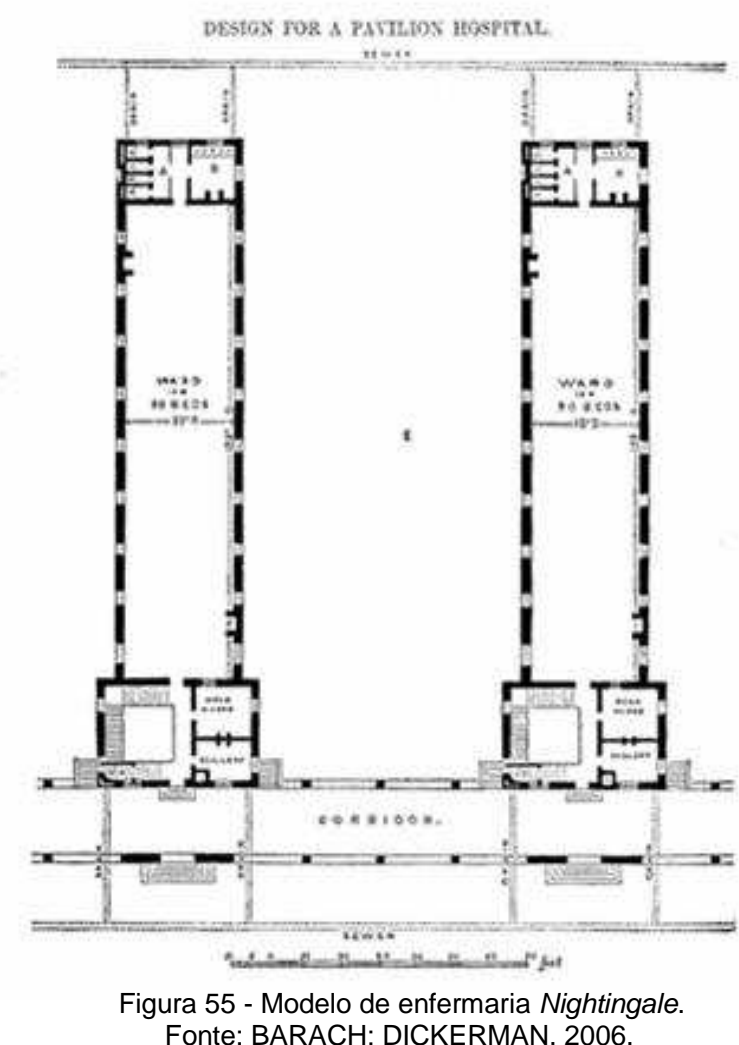

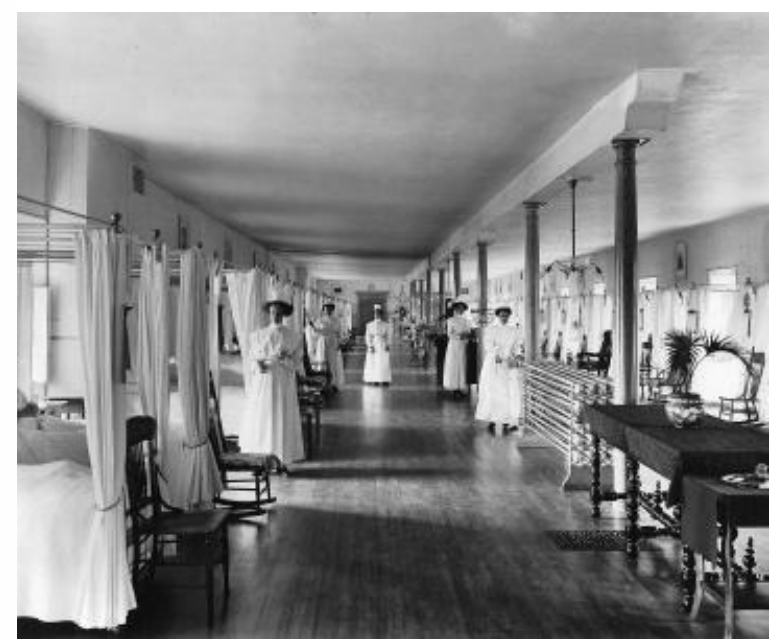

Figura 56 - Hospital Hotel Dieu, Montreal, início séc. XX. Fonte: McCord Museu.

A importância desse último aspecto, da ventilação e da insolação, no contexto geral, fez com que suas ideias fossem propagadas por toda a Europa, arejando e higienizando os interiores dos hospitais. Silva (1999) ressalta que, ainda hoje, o Hospital St. Thomas, em Londres, abriga esse modelo de enfermaria. Muitos hospitais foram construídos, nesse período, sob os conceitos de Nightingale e da tipologia pavilhonar, entre eles um dos que mais refletem essas influências é o John 
Hopkins Hospita (Figura 57), de 1980, em Baltimore nos Estados Unidos (DALLA, 2003).
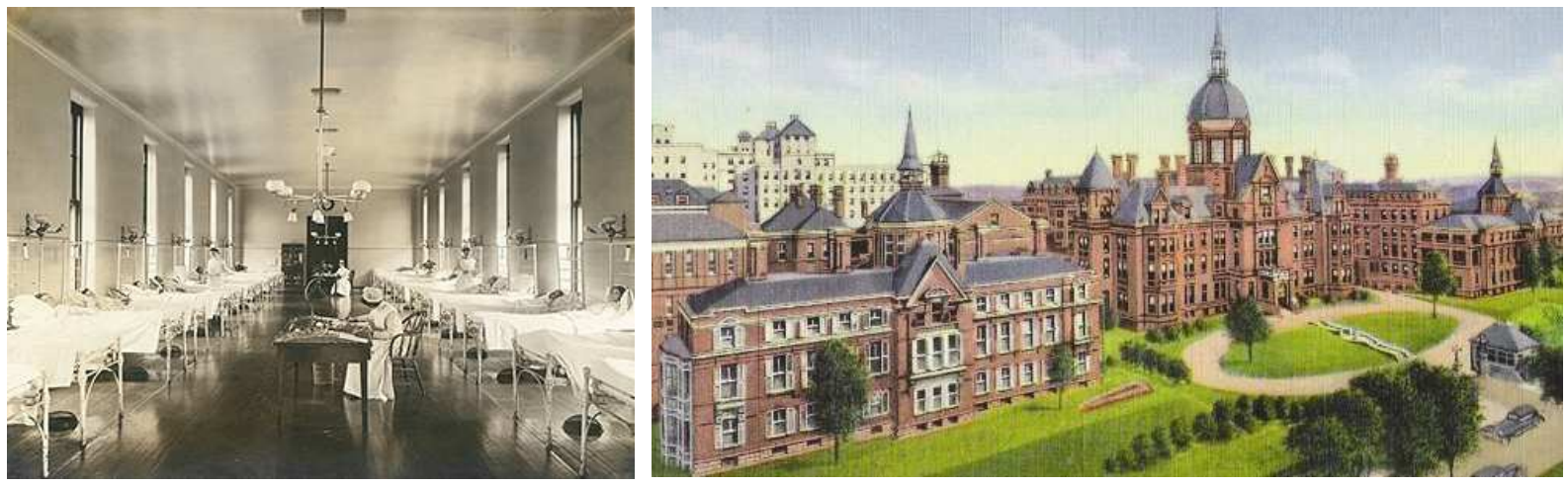

Figura 57 - John's Hopkins Hospital. Enfermaria em 1900 e vista externa.

Fonte: www.jhu.edu.

As ideias de Nightingale, de certa forma, suportavam a tipologia pavilhonar. Nessa tipologia especificamente, os arquitetos hospitalares criaram um conjunto de barreiras físicas, que tinham por objetivo conter a disseminação de infecções hospitalares, algumas das quais presentes até hoje, como as antecâmaras, vestiários-barreira, pró-pés e corredores exclusivos, de acordo com Santos e Bursztyn (2004).

Essas contribuições foram e ainda são importantes para o processo terapêutico dos pacientes, e, nesse aspecto, mais uma vez, fica claro o papel da arquitetura como agente de cura, assunto enfatizado por Foucault (1998), Toledo (2005) e Costi (2002). Ainda, no final do século XIX, as descobertas de Pasteur vêm apoiar as ideias de Nightingale.

Os evidentes avanços da medicina, ao longo do século XIX, trouxeram um maior conhecimento sobre os processos de transmissão das enfermidades; novos conceitos sobre a assepsia e com as descobertas dos antibióticos, minimizaram a necessidade das barreiras físicas criadas pelos arquitetos no modelo pavilhonar, de maneira tal que a arquitetura hospitalar e as práticas da medicina se distanciaram, nesse momento.

Nesse processo de distanciamento, duas consequências marcam o futuro do hospital: a participação do arquiteto dentro da concepção da estrutura física perde a importância, anteriormente adquirida, conforme enfatiza Toledo (2005): "[...] na medida em que os estudos dos fluxos, o dimensionamento dos ambientes e, até 
mesmo, o partido arquitetônico no pensamento de muitos, não mais contribuíam significativamente para o processo de cura [...]"; e a segunda consequência vem a ser a hierarquização a partir do médico, do poder do médico, este passa a ser a figura principal na organização do hospital (FOUCAULT, 1998).

Aos poucos, os preceitos de anestesia foram sendo vulgarizados, e associados à utilização de uma nova rotina de assepsia que obrigou a criação do bloco cirúrgico e dos serviços conexos (POMPEU, 2005), resultando numa especialização funcional do hospital, o que conduziu a uma importante modificação do espaço hospitalar. Ainda segundo Pompeu, com essas necessidades, até então desconhecidas, criouse o primeiro centro cirúrgico isolado em 1905, na Suécia e, nos Estados Unidos por volta de 1920.

Desse modo, com a remodelação do hospital, em que se passou a dispor de uma boa ventilação e iluminação de áreas destinadas exclusivamente às doenças infectocontagiosas, da constituição do bloco cirúrgico, de sistema de saneamento, entre outras modificações importantes, transforma-se o hospital, em um lugar ideal para os cuidados com a saúde. Assim, com essas modificações, o hospital que chegou ao século XX é bastante semelhante ao contemporâneo, e a forma ou tipologia adotada, considerada como ideal, era a pavilhonar, que tinha como uma das principais características as ligações através de corredores.

Para Rosen (apud LISBOA, 2002):

[...] os hospitais modernos emergem da gradual conversão do hospital geral, decorrente da secularização das entidades cristãs de atenção às doenças, por intermédio de quatro elementos principais; a introdução da medicina profissional em sua área; a redefinição de seu perfil institucional; a especificação de suas atribuições terapêuticas e o aproveitamento racional de recursos disponíveis.

Já nesse momento, o hospital constituiu-se como uma tipologia da arquitetura, projetado sob uma metodologia racional, focada, na função, e direcionada a partir dos eixos de circulação. Martinez (2000) considera que o hospital como tipologia, denominou-se no séc. XIX, pois, como esclarece, a tipologia é uma classificação de edifícios tendo em considerações traços comuns, ou seja, no sentido de categorias de distribuições - funções. 
As inovações tecnológicas, principalmente em relação ao concreto armado e aos elevadores, fizeram surgir, nos Estados Unidos, um novo modelo de hospital, 0 monobloco vertical, um dos exemplos de maior expressão dessa tipologia é o Hospital Beaujon, construído em 1932, na França (Figura 58). O crescimento populacional e a carência de espaço foram a força motriz dessa transformação, além de resolver dois dos maiores grandes problemas impostos pelo modelo pavilhonar, conforme Toledo (2002) aponta: os longos caminhos a serem percorridos e o controle da propagação de doenças.

O domínio da tecnologia do concreto armado e a fabricação de elevadores com maior velocidade e capacidade de carga estimularam a adoção do partido vertical, em oposição ao pavilhonar - horizontal, pois, tornaram capaz diminuir, de forma drástica, os longos percursos impostos, principalmente aos médicos e às enfermeiras, pelos intermináveis corredores dos hospitais pavilhonares.

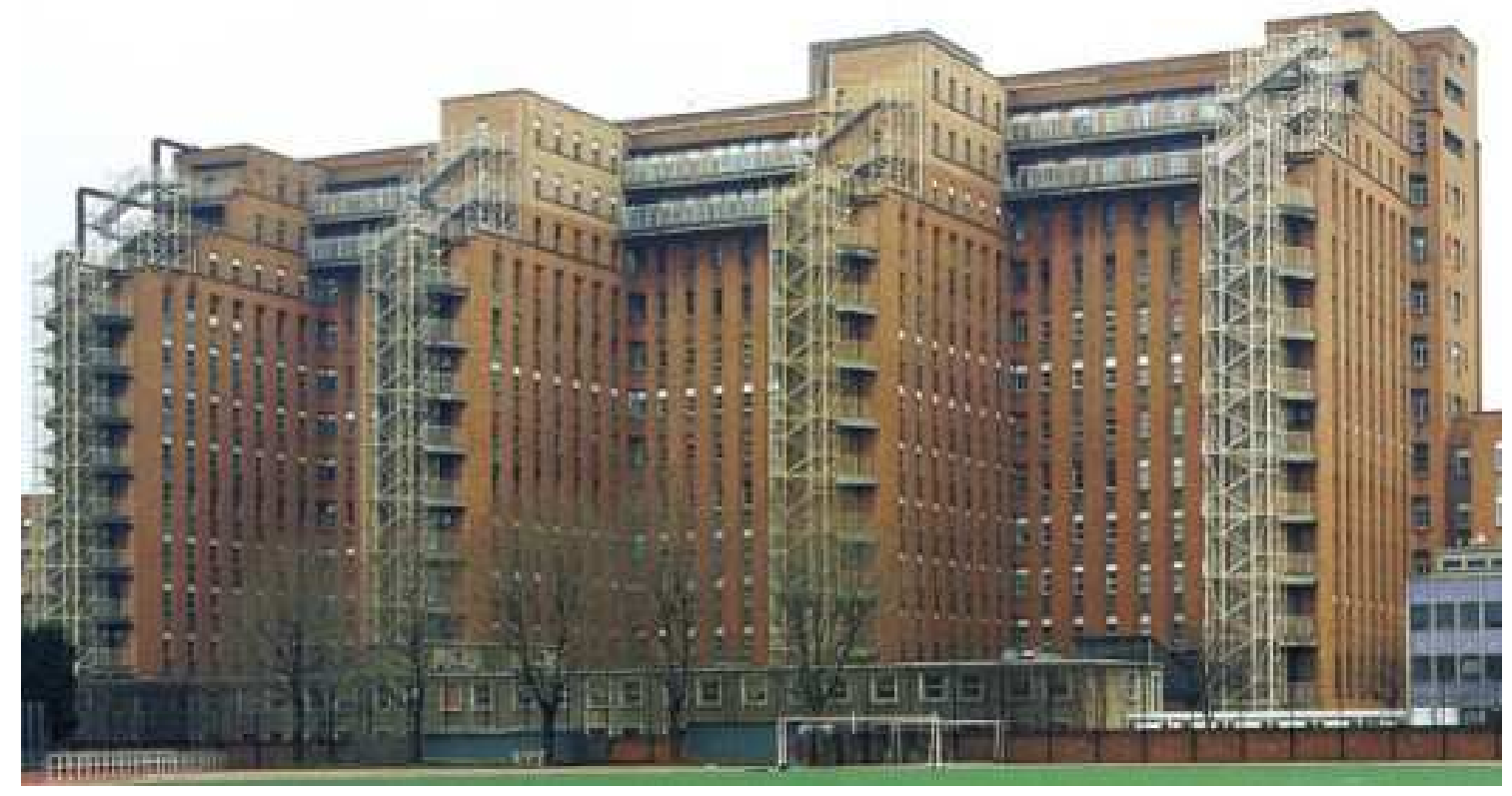

Figura 58 - Hospital Beaujon, Clichy/ França - 1929. Fonte: Beaujon,

Simultaneamente às transformações, na arquitetura hospitalar, ocorreram também grandes descobertas relacionadas aos procedimentos médicos: novas drogas surgiram, no sentido de aliviar o sofrimento do paciente, bem como no caminho da cura. A biologia, a química e a fisiologia fizeram grandes avanços. Todas essas mudanças só foram possíveis a partir de um novo olhar, de um novo modo de interpretar o mundo. 
Esse contexto histórico impulsiona o hospital monobloco a uma disseminação sem controle, e seu desdobramento para um enorme espaço, complexo e pesado, que Pompeu (2005) denomina "megahospital". E é na arquitetura, no estilo internacional e no modernismo, que o hospital monobloco teve o seu ápice; entretanto, a anatomia compacta desse "megahospital" mostrou-se despreparada para lidar com a evolução que estava por vir, mudanças, nos paradigmas dos conceitos de saúde e de assistência à saúde.

A partir dos anos 50, vários estudos direcionados à iluminação natural, nos hospitais, mostraram os benefícios desse recurso, propiciados pelo projeto arquitetônico; benefícios já levantados, ainda no séc. XIX. Nas pesquisas levantadas por Duffy (2008), Klich lida (2005), Carroll (2004), Cunha (2004) e Beck (2004), os resultados obtidos vieram a confirmar o quanto a ventilação natural aliada à iluminação natural diminuíam os índices de contaminação e alteravam, também, os dados clínicos dos pacientes, influenciando na recuperação desses (ULRICH, 1984, 2000a, 200b; COSTI, 2002). Curiosamente, sem muitos recursos tecnológicos, Nightingale já havia falado sobre os benefícios atingidos com esses recursos, como aponta Guzowski (1999).

Portanto, nota-se um retorno aos ideais focados, no hospital, como ambiente de cura, promovido por Foucault (1998). Mas é somente a partir dos anos 80, com a intensificação dos estudos, nesse campo, que Malkin (2008) considera que a arquitetura hospitalar se modifica de forma completa, não só, na questão física e nos aspectos funcionais, mas, dessa vez, a mudança atingiu o espaço como um todo: percepção e vivência deste, com consequência no design e ambientação.

Surge, então, um espaço mais humanizado, sendo essa a principal característica que vai guiar, nos anos seguintes, os debates sobre a arquitetura hospitalar e, consequentemente, afetar a produção arquitetônica dos hospitais contemporâneos. No debate, sobre a humanização do ambiente hospitalar, buscam-se parâmetros e diretrizes para a projetação, em pesquisas médicas e científicas. Essa nova arquitetura hospitalar, de certa forma, retorna aos preceitos da anatomia do hospital pavilhonar, com o foco no paciente, no bem-estar e no conforto. 


\subsubsection{Os Caminhos da Arquitetura Hospitalar Brasileira: A Partir das Santas} Casas de Misericórdia

No Brasil, a primeira edificação constituída como uma unidade hospitalar, considerada por Toledo (2004) foi o Hospital Santa Cruz da Misericórdia de Santos (Figura 59), criado por Braz Cubas em 1543. Após essa iniciativa, houve a disseminação das Santas Casas de Misericórdia, já difundidas em Portugal.

Com o decorrer do tempo, ocorreram inúmeras mudanças, principalmente na área de salubridade das construções. Houve maior atenção à ventilação e à iluminação naturais e às questões básicas de assepsia que, por sua vez, possibilitou minimizar os quadros de infecção hospitalar. Esses avanços ocorreram especialmente, nas Santas Casas, onde não havia inicialmente a preocupação quanto à higiene e ao conforto dos pacientes, com essas mudanças, foram elevadas ao patamar de estabelecimentos de referência.

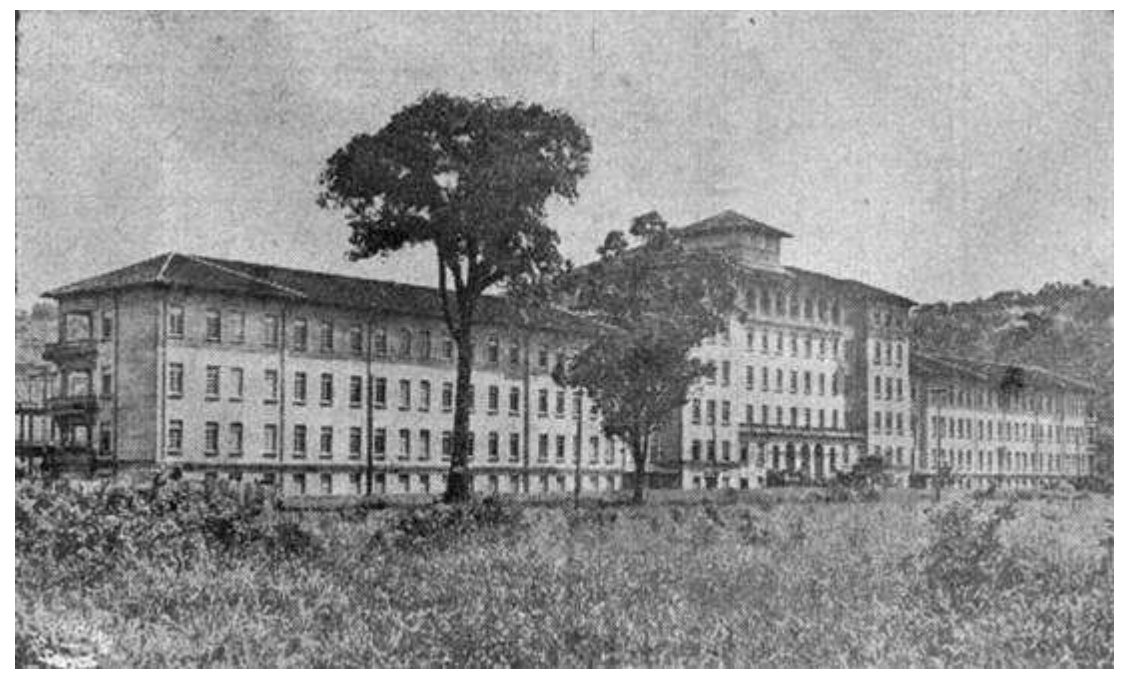

Figura 59 - Hospital Santa Cruz da Misericórdia de Santos. Fonte: Universidade Santa Cecília, acervo.

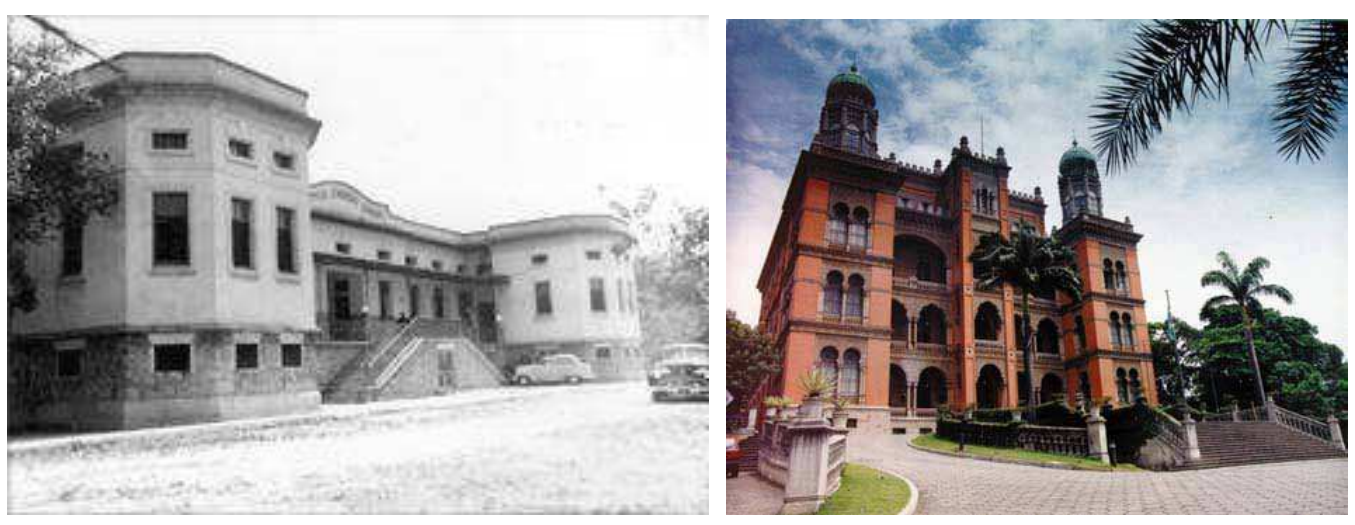

Figura 60 - Conjunto arquitetônico Histórico de Manguinhos, Fundação Oswaldo Cruz, início do séc. XX. Produção arquitetônica do Engenheiro Luiz de Morais Júnior. 
Fonte: Fundação Oswaldo Cruz.

A configuração do hospital como, nos moldes atuais, pode ser visto, nos primeiros exemplares dos projetos do Engenheiro Luiz de Morais Júnior (Figura 60). A principal mudança nesse modelo está, na tipologia, que deixou de ser pavilhonar para se tornar monobloco. Segundo Toledo (2004), o modelo de monobloco vertical mostrou-se vantajoso, principalmente com o surgimento de normas relacionadas às questões de salubridade, que tornaram os modelos de barreiras físicas, como o pavilhonar, obsoletos.

Pompeu (2005) considera que as principais mudanças quanto à anatomia do edifício hospitalar ocorreram, por volta de 1980, sob influência do médico sanitarista Odair Pedroso. Segundo Pompeu (2005), foi um dos pioneiros a criar e construir projetos hospitalares, no Brasil, embora, estes fossem copiados dos modelos norteamericanos. Alguns desses exemplares são as Santas Casas de Araraquara, de Catanduva, de Lins e na capital paulista, o Hospital das Clínicas da Faculdade de Medicina da Universidade de São Paulo, como pode ser visto na figura abaixo.

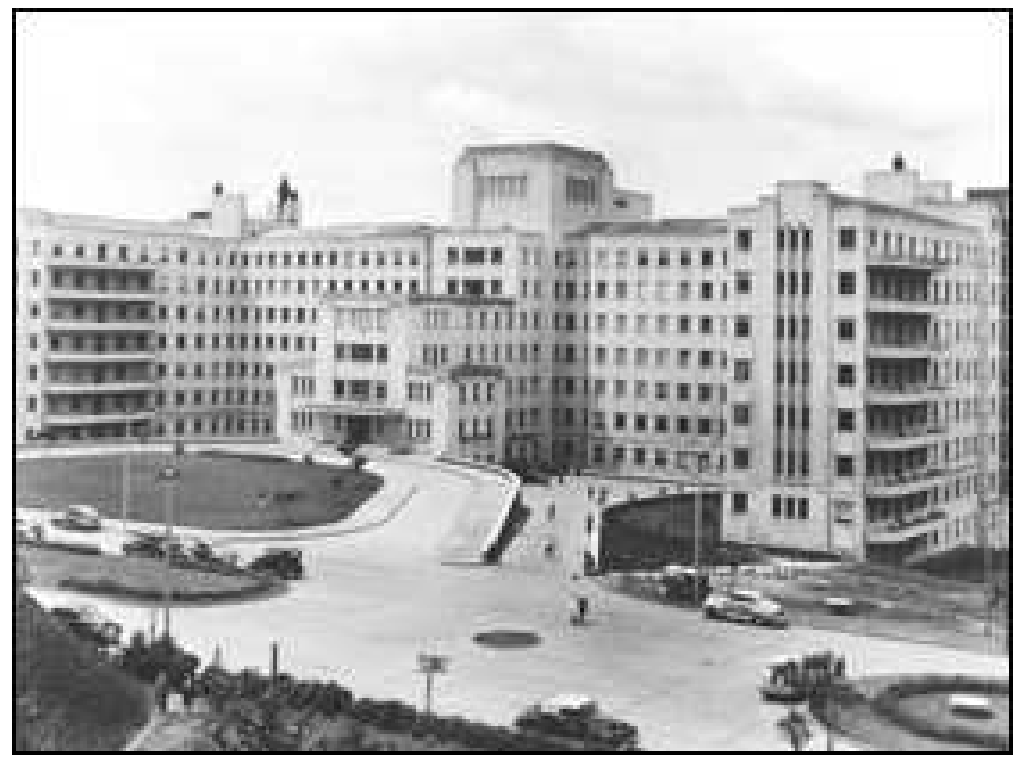

Figura 61 - Hospital das Clínicas da Faculdade de Medicina da Universidade de São Paulo, séc. XX. Fonte: Faculdade de Medicina da Universidade de São Paulo.

Com o predomínio do monobloco vertical e suas variantes, a produção arquitetônica hospitalar brasileira se alastrou, e conforme Toledo (2004) menciona, o monobloco tornando-se o partido dominante para os modernistas. O partido arquitetônico da tipologia do monobloco vertical consentia com a supervalorização das tecnologias médicas e inovações científicas, e a subvalorização do aspecto humano e desconsideração ao conforto ambiental (COSTI, 2002), uma das conquistas 
adquiridas pelo modelo pavilhonar que, até então, contribuía, no processo de cura. Nessa tipologia, a arquitetura hospitalar passa a ser somente um suporte físico para as práticas médicas.

No Brasil, alguns escritórios de arquitetura se especializaram na produção de projetos de Estabelecimentos de Assistência à Saúde (EAS), entre eles, podemos citar os dos arquitetos, Jarbas Karmam, João Carlos Bross, Siegbert Zanettini, Carlos Eduardo Pompeu e João Filgueiras Lima, Lelé. Alguns desses buscavam através de inovações arquitetônicas e conceituais soluções ao modelo, até então adotado. Nesse sentido, merece maior destaque a produção arquitetônica de Lelé.

Arquiteto responsável pela implantação dos hospitais da Rede Sarah Kubitschek SARAH, Lelé foi à contramão dos modelos dominantes ao resgatar o modelo pavilhonar do séc. XIX e os ideais propostos por Florence Nightingale (COSTI, 2002; LATORRACA, 2000). Através de uma releitura inovadora, teve como principal característica a adequação ao conforto ambiental, não só no que se refere à qualidade da planta física, mas também quanto à adequação das necessidades psicológicas e sociais dos usuários.

Sem abrir mão da qualidade estética, surgiu como um novo modelo para a arquitetura hospitalar contemporânea, sobretudo, ao aliar a tecnologia contemporânea ao processo construtivo, visando à sustentabilidade da edificação (LATORRACA, 2000), tema primário em todos os campos de estudo sobre o edifício hospitalar. Teve a preocupação centrada, na qualidade de vida dos usuários e do ambiente construído através da valorização da escala humana e suas relações.

Com essas características projetuais e conceituais, Lelé sintetiza, em seus trabalhos, as mais recentes diretrizes mundiais para projetos de edifícios hospitalares. A figura 62 apresenta alguns dos exemplares da produção arquitetônica de Lelé para a Rede SARAH de Hospitais, e mostra as principais características de sua obra.

Na história da arquitetura hospitalar brasileira, é possível observar, nos exemplares contemporâneos, os seus melhores momentos, representando a vanguarda da produção arquitetônica nacional, em conformidade com as tendências mundial de humanização do ambiente hospitalar. 

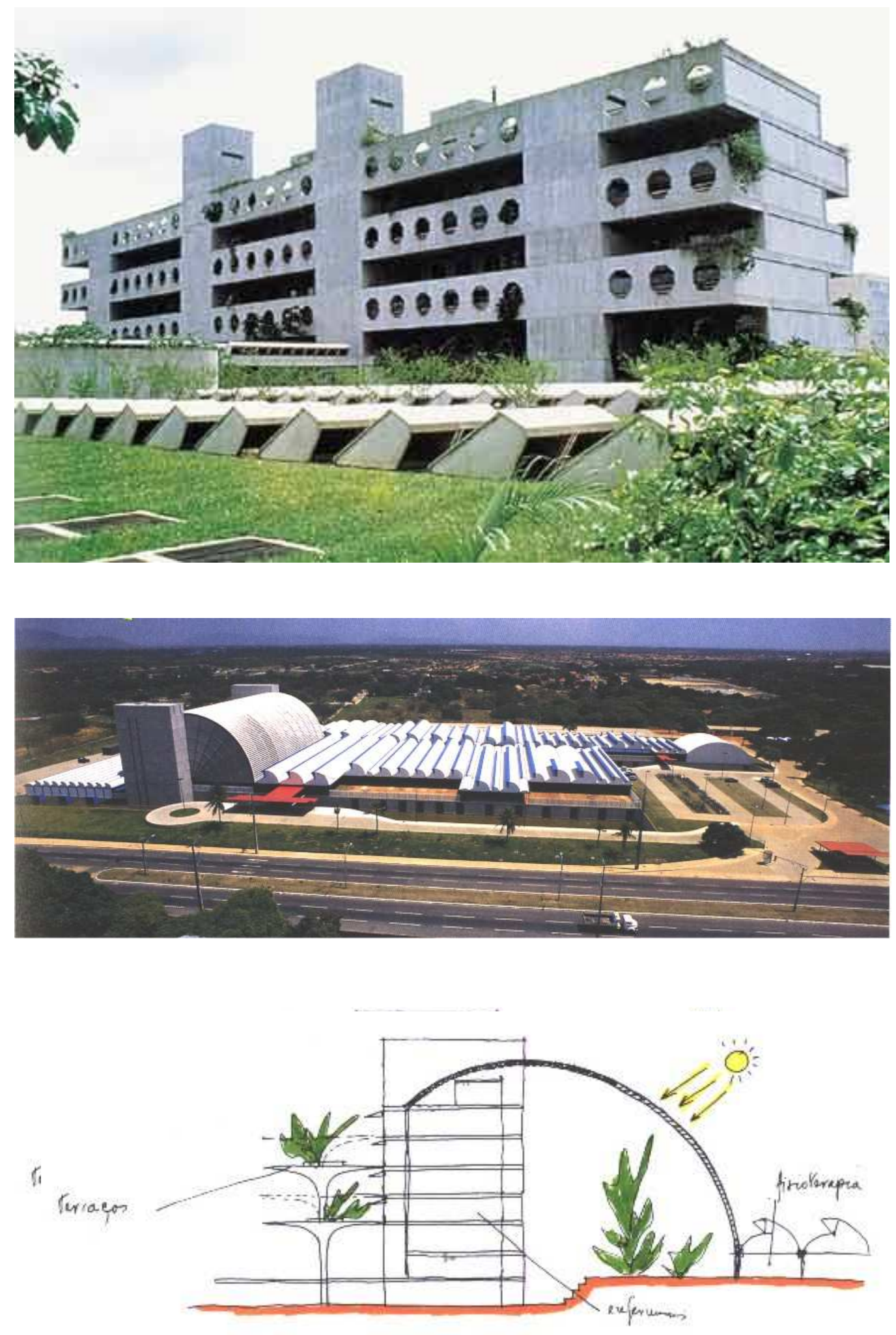

Figura 62 - Projetos da Rede de Hospitais SARAH.

Fonte: Latorraca, 2000. 


\subsubsection{A Normatização como Instrumento de Desenvolvimento do Edifício Hospitalar}

Os arquitetos, Oscar Waldetaro e Roberto Nadalutti, tiveram grande importância, no processo histórico de normatização da arquitetura hospitalar no Brasil, e segundo Toledo (2004), juntamente com o arquiteto Jarbas Karman, foram os precursores, no assunto. Ainda segundo Toledo, por meio da divulgação e da incorporação em seus projetos de certos aspectos normativos, eles introduziram, no país, os conhecimentos sobre a normatização hospitalar, esses, adquiridos em cursos específicos realizado nos Estados Unidos.

Por volta de 1950, o então Serviço Especial de Saúde Pública, (SESP), com contribuições de Roberto Nadalutti e Oscar Waldetaro, publica o documento Padrões Mínimos para Hospitais Gerais de 50 leitos e, em 1965, o Ministério da Saúde publica o Projeto de Normas Disciplinadoras das Construções Hospitalares. Concomitantemente, surgem, entre os próprios arquitetos e engenheiros do Ministério da Saúde, as primeiras manifestações de interesse quanto a uma regulamentação mais específica e abrangente do planejamento físico do hospital, resultanto, na elaboração e publicação, em 1974, das Normas de Construção e Instalação do Hospital Geral, pelo Ministério da Saúde (TOLEDO, 2004; POMPEU, 2005).

Segundo Regina Barcelos (apud TOLEDO, 2002, p. 162), com a política de ampliação do Programa do Fundo de Amparo Social, na década de 70, a necessidade de se criar parâmetros para orientar os projetos arquitetônicos ficou evidente. A falta desse tipo de material prejudicava a qualidade final da edificação, pois não permitia uma equidade de condições e diretrizes nacionais de projeto, 0 que impossibilitava mensurar e avaliar os projetos construídos até então.

Mediante esse panorama e com os esforços despendidos para suprir essas necessidades, em 1977, é elaborada a Portaria №. 400, uma publicação que dispunha sobre normas e padrões de instalação e construção em Serviços de Saúde. Nesse documento, o Ministério da Saúde apresentou aos projetistas do ambiente hospitalar parâmetros que orientavam os projetos físicos de hospitais com capacidade de até 150 leitos. No entanto, a norma não veio ao encontro dos reais anseios dos arquitetos hospitalares, pois não abrangia todos os aspectos que 
envolviam o planejamento de um edifício hospitalar, apenas padronizava os projetos arquitetônicos.

Como principal crítica a essa norma, Pompeu (2005) ressalta o extremo rigor quanto aos projetos, que remetiam diretamente às tipologias pré-estipuladas, delimitando a atuação do arquiteto, além de restringir o partido arquitetônico e a própria configuração estética e funcional da edificação. Como consequência, nota-se uma grande padronização, nos projetos, não havendo grandes diferenciações. A estandartização era tão evidente que, ao final da norma, algumas plantas eram sugeridas e combinações decorrentes dessas plantas eram mostradas, servindo como modelo para os projetos e soluções já padronizadas. O maior questionamento levantado, segundo Toledo (2002), era em relação à desconsideração das características específicas de cada setor e de cada hospital.

Barcelos (apud TOLEDO, 2002, p. 164) afirma que motivados pela Reforma Sanitária e pela aprovação da Lei Orgânica da Saúde dos anos 90, os próprios arquitetos do Mistério da Saúde buscaram modificar a Portaria nํ. 400/77, através de atualizações que contemplassem as lacunas deixadas por ela. Nesse período de extremas mudanças de regimento e estrutura operacional, também surgiu a implantação do Sistema Único de Saúde, um dos principais modelos públicos de atendimento à saúde no mundo.

Depois de três anos de elaboração, foi publicado a Portaria no. 1.884/94, que basicamente, consistiu em discorrer sobre os Projetos Físicos de Estabelecimentos Assistenciais de Saúde. Nessa Portaria, estabeleceram-se normas e diretrizes projetuais e dimensionais destinadas ao edifício de assistência à saúde, e um importante diferencial em relação às anteriores, é que essa norma respeitava a individualidade de cada setor, com suas especificidades e características próprias, além de abranger os diferentes setores do edifício de assistência à saúde (POMPEU, 2005).

Conforme descreve Pompeu (2005, p. 17), esse modelo propiciou uma maior flexibilidade para os projetos, permitindo que pudessem ser adaptados conforme a região e as necessidades. Extrapolando os limites do conhecimento da arquitetura, uma característica presente, na Portaria, foi a interdisciplinaridade, pois, em sua 
elaboração, contou-se com a colaboração de médicos, administradores, enfermeiros, engenheiros e arquitetos, o que garantiu atender, de modo geral, às necessidades de todos os setores.

Em virtude da evolução da complexidade dos edifícios destinados à assistência à saúde, em 2002, a Agência Nacional de Vigilância Sanitária (ANVISA), publicou a Resolução RDC n‥ 50, aprovando o Regulamento Técnico para o Planejamento, Programação, Elaboração e Avaliação de Projetos Físicos de Estabelecimentos Assistenciais de Saúde (EAS), e revogando a anterior (BRASIL, 2002). A resolução apresenta uma abordagem diferenciada e mais abrangente quanto aos setores analisados, decorrente da evolução da tecnologia médica e do avanço, na complexidade dos serviços e procedimentos de assistência à saúde.

Durante o processo de normatização, foi considerável a produção de outros documentos visando orientar e direcionar os projetos voltados aos ambientes hospitalares, foram manuais e guias produzidos com participações de importantes especialistas da área (BRASIL, 1995; KARMAN, 1995). Entre as maiores contribuições, está a do arquiteto, Jarbas Karman, responsável por um dos mais importantes e consultados materiais sobre controle de infecção hospitalar (KARMAN 1995).

A arquitetura é um dos elementos principais do universo hospitalar, sendo responsável por abrigar os serviços e prover estrutura para o desenvolvimento das atividades. Todas as diretrizes que vêm sendo estipuladas em guias, manuais e normas resultam em transformações, nas tipologias, e consequentemente, nas produções arquitetônicas nesses anos de implementação das normas.

Com maior liberdade projetual, a partir da Portaria №. 1884, surgiram vários modelos de hospitais, com as mais variadas tipologias e soluções arquitetônicas. Entretanto, era evidente a supervalorização dos aspectos físico-funcionais dos hospitais, resultando em projetos voltados para atender às necessidades da evolução tecnológica da medicina, das práticas médicas e das questões de adaptabilidade e funcionalidade.

Com o esgotamento desse modelo, surge uma necessidade por novas abordagens projetuais, como, por exemplo, a necessidade de além de suprir as questões de 
conforto e saúde, suprir as questões de bem-estar psicológico, social e humano.

O Ministério da Saúde (2001), conhecendo a necessidade de ampliar os aspectos regulamentados pelas portarias, lança, em 2004, um manual de procedimentos para a humanização do ambiente e serviço hospitalar. O manual, idealizado pelo Programa Nacional de Humanização da Assistência Hospitalar (PNHAH), nasceu da iniciativa do Ministério da Saúde em buscar estratégias que possibilitassem a melhoria do contato pessoal entre profissionais da saúde e usuário, dos profissionais entre si e do hospital com a comunidade, visando ao bom funcionamento do Sistema de Saúde Brasileiro (SUS).

Como objetivo principal, o PNHAH pretendia promover uma requalificação dos hospitais públicos, valorizando, dessa forma, a dimensão humana e subjetiva presente em todo o ato de assistência à saúde; o manual além de propor parâmetros de atendimento, relação profissional e interpessoal, condições de tratamento com o usuário, também apresenta parâmetros que estão relacionados diretamente às atribuições da arquitetura, enquanto espaço que abriga essas relações.

Os hospitais, em conformidade com os padrões de assistência e funcionamento global dos indicadores de humanização e com os princípios e diretrizes do PNHAH, recebem a certificação de "Hospital Humanizado", o que constata, portanto, a característica mundial crescente de busca pela humanização do ambiente hospitalar e o uso de certificações como meio de incentivo. Diferentemente do Brasil, nos Estados Unidos, essas certificações são concedidas visando não apenas às questões de humanização, mas também, àquelas relacionadas à sustentabilidade das edificações"'.

\subsection{UMA VISÃO SOBRE A HUMANIZAÇÃO HOSPITALAR}

Entorno da palavra hospital, durante muito tempo, criou-se uma noção que o relacionava a um ambiente obscuro e de morte, muitos foram os esforços para

\footnotetext{
${ }^{11}$ Nos Estados Unidos existe uma certificação que visa à sustentabilidade da edificação e engloba inúmeros requisitos, entre eles, conforto ambiental e humanização do ambiente hospitalar. Essa certificação denominada LEED - Liderança em Energia e Desenho Ambiental - (Leadership in Energy and Environmental Design), concedida pelo USGBC - United States Green Building Council - organização não governamental americana reconhecida internacionalmente, cujo foco é a sustentabilidade das edificações e de empreendimentos imobiliários em parceria com o GGHC - Green Guide for HealthCare, Guia verde para o cuidado à saúde - é uma organização não-governamental destinada à indústria médica, hospitalar, clínica e centros de saúde.
} 
modificar essa condição de medo e inúmeros foram os atores participaram das maiores mudanças acontecidas nesse ambiente tão complexo ${ }^{12}$. Ao contrário de quase toda história do edifício hospitalar que relacionava essa edificação ao tratamento da doença, atualmente, esse edifício tem como fundamento o predomínio do conceito de promoção à saúde (BRASIL, 2001). Uma significativa mudança no paradigma de cuidados da saúde.

No Brasil, até os anos 90, a arquitetura hospitalar proveu os edifícios de assistência à saúde com soluções técnicas sempre acompanhando a evolução da medicina. Os espaços hospitalares foram quase sempre projetados para munir adequadamente os serviços oferecidos, com uma preocupação voltada para a solução de adequações físicas do espaço como, flexibilidade, modulação, funcionalidade, enumera Pompeu (2005). Portanto, eles eram construídos de forma a acompanhar os avanços técnicocientíficos, pois, à medida que surgiam novas descobertas, o edifício possuía condições espaciais, para se adaptar a elas.

Os estabelecimentos assistenciais de saúde são complexos, abrigando diversos setores, cada um com sua especificidade e função. São empreendimentos que exigem grandes investimentos, na construção, na compra de equipamentos e, principalmente, na manutenção dos custos operacionais. No setor publico, esses custos operacionais crescem proporcionalmente às transformações construtivas executadas sem planejamento. Além disso, os problemas iniciais de projeto, decorrentes de soluções arquitetônicas inadequadas ao clima, são agravadas com as ampliações para o atendimento da demanda crescente de pacientes e o acompanhamento de novas tecnologias e equipamentos. (MARTINS, 2004, p. 63).

No final dos anos 90 e anos subsequentes, surgiu como principal diretriz para a projetação de estabelecimentos de assistência à saúde o conceito de humanização. Conceito que, conforme Martins (2004) aponta, consiste em um conjunto de ações de vários personagens, em várias escalas e áreas, e segundo o Ministério da Saúde (BRASIL, 2001), humanizar é:

[...] resgatar a importância dos aspectos emocionais, indissociáveis dos aspectos físicos na intervenção em saúde. Humanizar é aceitar essa necessidade de resgate $e$ articulação dos aspectos subjetivos, indissociáveis dos aspectos físicos e biológicos. Mais do que isso, humanizar é adotar uma prática em que profissionais e usuários consideram o conjunto dos aspectos físicos, subjetivos e sociais que compõem o atendimento à saúde. Humanizar refere-se, portanto, à possibilidade de

${ }^{12}$ Entre outros, Florence Nightingale, enfermeira precursora das enfermarias modernas, introduziu mudanças quanto ao espaço físico das enfermarias, como aberturas, e outras questões relacionadas à assepsia. 
assumir uma postura ética de respeito ao outro, de acolhimento do desconhecido e de reconhecimento dos limites.

Paralelamente à ampliação desse conceito, surgiu um método de projeto que considerava o usuário hospitalar como a um cliente, e que deveria ser servido com vários benefícios de hotelaria, passando, o hospital, a ser projetado como a um hotel. De acordo com Lukiantchuki e Souza (2010), Jarbas Karmam e Lauro Miquelin acreditam ser este o caminho para a humanização, como expõem:

[...] Karma cita que 'projetos de hotéis onde o hóspede às vezes fica apenas um dia exigem tratamento especial para atrair o público. O mesmo deve ocorrer com o hospital, onde a permanência é mais prolongada' [...] para Miquelin 'A meta é multiplicar exemplos de excelência para que possamos, daqui a pouco, entrar em um hotel bem planejado e ouvir alguém dizer que parece um hospital' [...].

Entretanto, esse modelo recebeu várias críticas de inúmeros atores do cenário hospitalar, abrindo espaço para outras reflexões.

\subsubsection{A Humanização do Ambiente Hospitalar Focada no Paciente: A Arquitetura como Agente de Cura}

Nesse cenário, vêm à tona estudos iniciados com a psicologia ambiental que demonstram que o ambiente influencia, no comportamento dos usuários do espaço físico, criado pela arquitetura. Estudos voltados, especificamente, para a área de saúde e ambiente, os quais se destacam os estudos do Professor Roger Ulrich, do College of Architecture, Texas A\&M University (1984, 2000a, 2000b, 2002, 2008), mostram o quanto o ambiente influi, no processo terapêutico do paciente; em decorrência desses e de outros estudos, como os de Rubin, Pronovost e Diette (2001) desenvolvidos no John's Hopkins Hospital, novas diretrizes são estipuladas para o projeto do ambiente hospitalar, com o foco, na satisfação e no bem-estar dos pacientes, e de acordo com Birch, Curtis e James (2007), voltado para as necessidades psicológicas e sociais.

Em concordância com essas diretrizes inovadoras para o ambiente hospitalar, está a nova conceituação do termo saúde, coincidindo com os novos parâmetros de conceituação de saúde, que hoje tem por definição, segundo a Organização Mundial de Saúde (apud LUKIANTCHUKI; CARAM, 2008, p.6): "[...] saúde é o estado de 
mais completo bem-estar físico, mental e social, e não apenas a ausência de enfermidade".

Se for aprofundada a questão de conceito de saúde, encontramos algumas considerações acerca do tema. Ao se explorar a diferença entre cura e saúde, encontram-se informações que podem influenciar no design do ambiente construído, segundo Leland Kaiser (apud GUZOWSKI, 1999, p. 333):

[...] a cura é científica, tecnológica e focada em pacientes como corpos e a saúde é espiritual, experimental e focada, no paciente como pessoas, a cura é high-tech, e a saúde é contato humano. O ambiente saudável é pessoal, ele enriquece a experiência humana, encarece os sentidos e deixa as pessoas saberem que eles são individuais.

Todas essas mudanças se dão entre o final do séc. XX e o início do século XXI, prevalecendo até os dias atuais. O interesse, nesse assunto ainda, é grande, e como Ulrich (2000b) menciona, ainda está em um processo crescente de adequação e descobertas, pois, como é possível verificar, na literatura, novas pesquisas estão sendo realizadas, com diversas abordagens no ambiente construído, verificando quais os elementos que podem influenciar na qualidade do ambiente. $\mathrm{Na}$ área hospitalar, as pesquisas são ainda mais intensas, e relevantes, e como Malkin (2008) assinala, estão nos primeiros passos.

Alguns resultados já obtidos pelas pesquisas realizadas, primeiramente, demonstraram que o ambiente influi no comportamento psicossocial e psicobiológico dos seres humanos, determinando reações fisiológicas e psicológicas dos usuários; apontamentos do arquiteto Alan Dilani (2000), pesquisador do Swedish National Institute for Psychosocial Factors and Health, conduzindo pesquisas científicas sobre os impactos da ambiente físico em atividades de cuidado à saúde, no Karolinska Institutet, e um dos fundadores do International Academy for Design and Health (IADH).

Em Dalla (2003, p. 20, grifo do autor) encontra-se uma reflexão sobre o tema, que reflete as questões acima mencionadas:

Segundo Hall, o espaço age como uma "linguagem silenciosa" no inconsciente do ser humano. E essa interação, espaço-comportamentopercepção, traz maiores dados para a execução de um projeto de arquitetura, além de apontar as preocupações com o desempenho físicoespacial do edifício, cujas preocupações englobam também, o respeito às especificidades sócio-psico-culturais dos usuários hospitalares. 
Os trabalhos mais relevantes nesse sentido são demonstrados por Ulrich (1984, 2000b, 2008), dentre os quais alguns já foram anteriormente mencionados. Um de seus estudos a respeito dos impactos da iluminação natural em Unidades de Tratamento Intensivo (UTI), concluiu que o uso de iluminação natural, nesses ambientes, diminui o tempo de internação, também constatou que o acesso dos pacientes à iluminação natural é capaz de diminuir a dor e a depressão. Ulrich também vem se aprofundando em outros temas, como o uso de jardins internos para pacientes, os quais, segundo ele, têm grande efeito terapêutico no controle do estresse e nas reações de ordem fisiológicas, como a diminuição da pressão sanguínea.

Tanto Ulrich (1991) quanto Malkin (1991) apontam ainda o fato de o paciente ter controle do ambiente em que se encontra. O simples fato de poder aumentar ou diminuir o som da televisão, abrir ou fechar as persianas, controlar a luz e controlar a temperatura de seu quarto diminuem muito o estresse do paciente, uma vez que ele pode controlar o ambiente ao seu redor de acordo com seus gostos, dando-lhe autonomia.

Nota-se uma assiduidade da busca pelo conforto, seja ele lumínico, acústico, estético, ergonômico, visual, em todos os estudos relacionados ao desenvolvimento de projetos da arquitetura hospitalar, cabe aqui, apresentar uma definição atual do termo conforto, que é apresentada por Schmid (2005, p. 23):

[...] O conforto é mais que a ausência de dor e pode ser aprimorado, mesmo se a dor não pode ser tratada inteiramente, através da atenção à transcendência. $\mathrm{O}$ incremento do conforto envolve aumento da esperança e confiança e pode diminuir as complicações relacionadas à alta ansiedade dos pacientes.

Essas inovações, no hospital do séc. XXI, são patrocinadas e pesquisadas por entidades relacionadas ao desenvolvimento do edifício hospitalar, focadas no incremento de qualidades no edifico hospitalar, entre elas United States Green Building Council (USGBC), Green Guide for HealthCare (GGHC) , American Society of Healthcare Engineering of the American Hospital Association (ASHE), The Center for Health Design e Agency for HealthCare Research and Quality, Planetree, entre outros.

No Brasil, existem entidades voltadas ao estudo do edifício hospitalar, como a 
Associação Brasileira para o Desenvolvimento do edifício Hospitalar (ABDH), e ainda grupos dentro de universidades com esse foco, caso do Grupo de Estudos em Arquitetura e Engenharia Hospitalar, da Universidade da Bahia, no entanto, mais timidamente, e sem muitos recursos e produções científicas, acabam por desempenhar um papel na divulgação de informações de assuntos relacionados ao tema.

Segundo o escritório, Bross Arquitetura e Consultoria (apud CORBIOLI, 2003), um dos escritórios de arquitetura hospitalar do país com maior produção na área, existem alguns pré-requisitos de projetação para o edifício hospitalar que devem ser buscados, dentre eles os denominados ergonômicos: atender a especificações dimensionais e condições ambientais que permitam correta habitabilidade, visando à melhor produtividade e eficácia e, os psicológicos: atender a condições que os tornem mais adequados às percepções e comportamentos. Sobre as necessidades dos pacientes e a relação com o ambiente, Pompeu (2005) expõe algumas considerações relevantes:

\begin{abstract}
Na verdade existe uma linha muito estreita entre "a beleza da humanização hospitalar" e a "eficiência da humanização hospitalar". Projetar um ambiente que promova a cura não significa apenas criar um ambiente agradável, confortável e com elementos que remetam o paciente ao ambiente familiar. É preciso muito mais. É preciso ter conhecimento das razoes cientificas pelas quais certos elementos fazem bem ou mal aos pacientes, é preciso entender porque algumas sensações são provocadas pelo espaço físico e como os pacientes podem percebê-las, é preciso saber a respeito da doença que atinge o usuário daquele espaço para poder proporcionar a ele um ambiente positivamente na sua recuperação.
\end{abstract}

Desse modo, como visto ao longo da dissertação, os valores hoje buscados para o desenvolvimento de projetos hospitalares atuais estão relacionados ao uso da iluminação natural, das cores, de materiais inovadores e de alta performance, e da sustentabilidade da construção. As cores, por sua vez, são, dentre os elementos, os que mais vêm se destacando, como agente transformador da experiência hospitalar, conforme César (2003, p. 36) relata:

[...] alguns ambientes cujo uso é previamente conhecido, condicionam o usuário a determinados estados emotivos. Nessa situação, havendo por parte do usuário uma pré-disposição a determinadas composições cromáticas, podem, associadas aos demais aspectos ligados à percepção, como as reações fisiológicas, aspectos culturais, etc., facilitar a captação de arquétipos (imagens psíquicas do inconsciente coletivo, e que são patrimônio comum a toda a humanidade), relacionados à atividade ali exercida. [...] 


\subsection{INTER-RELAÇÕES: HOSPITAL, COR E SAÚDE}

A literatura sobre o histórico do emprego das cores, na arquitetura hospitalar, especificamente, é escassa e dispersa, de maneira tal, que falar sobre esse assunto se torna um desafio, tornando complexo saber como as cores eram usadas, com quais finalidades, e quais eram os métodos de composição para o ambiente hospitalar. Já a relação entre cor e saúde pode ser encontrada em várias disciplinas e possui uma considerável literatura. O que a história nos mostra é que a saúde e a medicina estiveram sempre cercadas por mitos e técnicas de cura, por meio dos possíveis poderes da cor.

As disciplinas, cor e saúde, encontram, na Antiguidade, conexões e associações, de maneira a relacioná-las. Os egípcios já se utilizavam das propriedades curativas das cores. Os médicos banhavam seus pacientes em luzes coloridas para curarem as doenças, menciona Singh (2006). O uso da cor, portanto, referia-se, exclusivamente, a uma indicação médica de tratamento, não sendo ainda aplicada, na arquitetura, de forma diferenciada e/ou planejada. Em Costi (2002, p. 73), contudo, encontram-se algumas referências sobre o assunto, segundo ela, os antigos templos, os quais eram reservados aos tratamentos de saúde, tal como o Templo de Asclépio, consistiam em composições policromáticas.

Sobre o emprego da cor, nos hospitais da idade média, pouco se relata, restando apenas algumas indicações, eram ambientes frequentemente escuros, pouco iluminados, e com materiais e cores, também, escuras. Característica essa que não perdurou nos hospitais do final do séc. XVIII e começo do séc. XIX, pois, o que se constata é que as descobertas, nas áreas de higienização, promoveram uma verdadeira limpeza no ambiente hospitalar, uma vez que relacionaram o ambiente com a saúde em termos de assepsia, os revestimentos e as cores refletiam essas preocupações.

Os fantasmas dos hospitais da Idade média perseguiam a mente e a instituição em si, assim, o uso da cor branca como padrão foi estandartizada, produzindo ambientes limpos e brancos, para iluminar, finalmente, o hospital, e apagar as memórias da escuridão do passado.

No entanto, esse ambiente todo branco, do ponto de vista da percepção, não era 
considerado salutar. Tofle et al. (2004) levantam que a cor branca, empregada no ambiente, combinação de paredes, teto e piso brancos, traz consigo condições, perceptualmente, estranhas ao ser humano, uma vez que o ser humano vive na variedade cromática, desde seu nascimento. Essa ausência de cor pode ser interpretada como um excesso de neutralidade que conduz à falto de vitalidade e ao vazio, considerada por eles, psicologicamente, perigosa.

Seguindo essa mesma linha, Baughan-Young (2001, tradução nossa) ressalta: "[...] paredes brancas têm um aspecto clínico que é desconhecido e estranho para a maioria das pessoas, a ausência de cor é assustador". São considerações relevantes a respeito de uma vertente que possuía uma tendência histórica em manter uma aparência estéril e sanitária, nos quartos dos pacientes, enfermarias e salas, criando espaços vazios.

Ao longo do século XIX, os acabamentos do ambiente hospitalar, contrariamente ao ambiente limpo e asséptico, traduzidos pelo emprego da cor branca, foram aos poucos se modificando e passaram a ser predominantemente em cores mais escuras. A cor que prevalecia no período era o marrom; mas que, ao longo do tempo, foi considerado negativo, salienta Costi (2002). Outras composições também são relatadas por Costi (2002), tais como o uso dos tons cinza e verde para ambientes com alta iluminância e "creme" para aqueles com baixa iluminâcia. $\mathrm{O}$ matiz vermelha, ocre e marrom formavam a composição final sendo aplicados em detalhes, "[...] passando aspecto de cores quentes [...]" (COSTI, 2002, p. 75).

Sobre o assunto em questão, Malkin (2008) faz uma comparação digna ao comparar os corredores hospitalares existentes até a década de 70, onde as iluminações eram fracas e obscuras, as cores neutras, e as perspectivas dos corredores que davam no nada, com a clássica obra, de Edvard Munch, $\mathbf{O}$ Grito. Ao se olhar para a imagem, dificilmente não se terá a percepção de ouvir um grito, e sentindo a sensação de desolação, dor ou sofrimento; tais sensações era para Malkin, as que os hospitais do período passavam.

No meados do séc. $\mathrm{XX}$, houve iniciativas de modificar esse ambiente, trazendo mais cores e mais vivacidade para o ambiente hospitalar, dentre essas iniciativas, destaca-se a de H. Kemp-Prossor, por volta de 1917, que fez-experimentos tentando 
reduzir sensações negativas dos pacientes, segundo César (2003, p. 167) "[...] através de uma aproximação com os elementos da natureza [...]". César (2003, p. 183) descreve como consentiu o experimento: "Ele pintou o teto de azul de forma a se aproximar o máximo possível do céu; as paredes são pintadas de forma a representar as folhagens da primavera e o piso é pintado com um amarelo esverdeado". No entanto, experimentos como esse encerram-se aqui.

No contexto brasileiro, o emprego das cores no ambiente hospitalar, não foi tão diferente do panorama mundial. Costi (2002) menciona que, entre as décadas de 40 e 60, as cores utilizadas nos hospitais eram aquelas que estavam disponíveis no mercado, e que prevaleciam aquelas que tinham um aspecto de sujeira, já nos anos 60 e 70, com o uso inovador de divisórias, material até então ausente no ambiente hospitalar, houve uma maior variedade cromática, pois esse material era apresentado em variados revestimentos.

Observando-se a produção arquitetônica hospitalar mundial, constata-se que é somente, do final do séc. XX e início do séc. XXI, que realmente ocorrem mudanças consideráveis em termos de composição cromática. Muito se deve aos materiais inovadores, mais resistentes e tecnológicos, mas, sobretudo, as mudanças ocorrem pressionadas por uma necessidade de reformulação da ambientação hospitalar.

De um lado, a necessidade de conquistar o paciente, proporcionando ambientes mais confortáveis e esteticamente mais valorizados, satisfazendo seus anseios. Por outro lado, uma vez as questões físicas e funcionais resolvidas, o design e ambientação, deixados de lado por décadas, senão séculos, urgiam com novas soluções e perspectivas, indo ao encontro das novas diretrizes, de humanização do ambiente hospitalar, estabelecidas pelo movimento empenhado em melhorar as qualidades desse ambiente.

Para Malkin (2008), foi somente a partir dos anos 80 que os hospitais se reformularam completamente, nas questões relacionadas ao design como a iluminação, a cor e o próprio projeto, focado no bem-estar do paciente, e que, segundo ela, tal revolução teve como principal agente precursor a Planetree ${ }^{13}$. Nos

\footnotetext{
${ }^{13}$ Organização sem fins lucrativos, criada em 1978, na Califórnia, Estados Unidos, que promove um conceito de assistência à saúde em que alia cuidados médicos ao suporte emocional do paciente, chamado de Patient-Centered Care. (PLANETREE, 2009).
} 
anos 90, o design de hospitais ganha a mídia, com revistas e editoriais, além de uma maior divulgação de pesquisas e projetos possibilitada pelo advento da internet, a qual teve grande importância colocando as informações ao alcance de todos e acelerando essas discussões.

Dentre todas as inovações pelas quais o ambiente hospitalar vem passando, a programação cromática é, sem dúvida, um dos principais elementos. Nesse aspecto, o uso de cores teve considerável divulgação, referindo-se desde seu uso em materiais e superfícies, até na arte e funções específicas, como a de orientação, abrangendo uma abordagem funcional a uma mais psicológica, mas, sobretudo, se sobressaindo a sua dimensão emocional. 
CAPÍTULO 7 APLICABILIDADE DAS CORES NO AMBIENTE HOSPITALAR 


\section{CAPÍTULO 7}

\section{APLICABILIDADE DAS CORES NO AMBIENTE HOSPITALAR}

\subsection{POSSIBILIDADES DO USO DAS CORES NO AMBIENTE HOSPITALAR}

Como apresentado ao longo dos Capítulos, algumas cores possuem simbologias, e essas podem relacionar-se com diversas reações, fisiológicas, biológicas e psicológicas. No que se refere ao âmbito das simbologias, a representação das cores, em muitos casos, são universais, como mostram os estudos de Oberascher; Oberascher e Gallmetzer (2005), Da Pos e Green-Armytage $(2006,2007)$ e Da Pos e Valentini (2005), que concluem que mesmo tendo significados diferentes entre povos, algumas cores possuem um significado de reconhecimento geral.

Esse é apenas um aspecto a ser considerado ao se propor um esquema cromático para um ambiente hospitalar. Outros aspectos relevantes, para a aplicação de composições cromáticas, estão relacionados às dimensões das cores, ou seja, seus atributos matiz, saturação e luminosidade e aos atributos de percepção, vistos no Capítulo 5.

Para Tofle et al. (2004), a importância desses aspectos para as composições reside no fato de que conforme a faixa etária do usuário, a percepção de aparência da cor varia consideravelmente, principalmente pela variação de acuidade visual, devendose compor esquemas utilizando a integração entre os atributos da cor e as características de aparência, para se obter um resultado visual mais adequado, Feisner (2006) menciona, por exemplo, que idosos e crianças são mais perceptivos a matizes mais saturados, enquanto jovens e adultos a matizes menos saturados, no entanto, com maior luminosidade.

Também verifica-se que para cada setor há uma necessidade diferente de ambientação, para que se desenvolva de forma eficiente e produtiva as atividades ali desempenhadas, além de se considerar a necessidade de se suprir a dimensão psicológica. Também devem entrar nas diretrizes de um esquema cromático de um determinado ambiente, as finalidades e objetivos que a cor pretende desempenhar em cada ambiente. 
Essa exposição procurou mostrar a variedade de aspectos envolvidos entorno das cores, e que para o seu uso no ambiente hospitalar, várias são as formas de abordagens que podem se dar: simbólicas, psicofisiológicas, culturais e individuais, técnicas, funcionais e estéticas, podendo esses delinear conceitos para a sua aplicação.

\subsection{OUTRAS FUNÇÕES}

Guzowski (1999) nos fornece uma relação de fatores que deveriam ser criteriosamente revisados para as definições do uso da iluminação natural na arquitetura. Em seu ponto de vista, nota-se uma preocupação quanto à definição de qual uso se deseja fazer da iluminação natural, em outras palavras, qual é a intenção. Para ela, essa questão é de extrema importância, pois, é o ponto de partida para a elaboração de qualquer projeto, e servirá de argumento e sustentação do partido adotado.

Os fatores são: preocupações ecológicas, atividades e tarefas a serem desenvolvidas, inter-relação de sistemas, experiência humana e considerações estéticas. Claramente, a maioria dos fatores por ela enumerados poderia também servir para métodos de aplicação e uso da cor, na arquitetura.

As cores ou composições cromáticas, em um hospital, estão presentes em todo o espaço visual; desde os uniformes, equipamentos, até obras de arte e mobiliário, e juntamente a outros elementos arquitetônicos, compõem o espaço. Ela, no entanto, não serve somente como um elemento estético ou decorativo em um ambiente; pode desempenhar outras funções, como a de prover informação como, por exemplo, a orientação das circulações e a setorização das áreas em um hospital.

\subsubsection{Orientação}

O uso da cor como ferramenta de orientação encerra em si um senso de direção, dando referenciais para os usuários do edifício hospitalar. Essas informações promovem a mobilidade dentro do edifício, tornando rápido e fácil o acesso ao ponto a que se deseja chegar (Figura 63). Dalke, Littlefair e Loe (2004) indicam que todas 
as informações, usadas para esses fins específicos, devem ser repetidas constantemente, formando um sentido de direção. A informação deve ser passada por meio de um sistema visual simplificado, criando uma identidade visual facilitando a leitura e o entendimento (READ, 2003), através de uma estratégia clara.
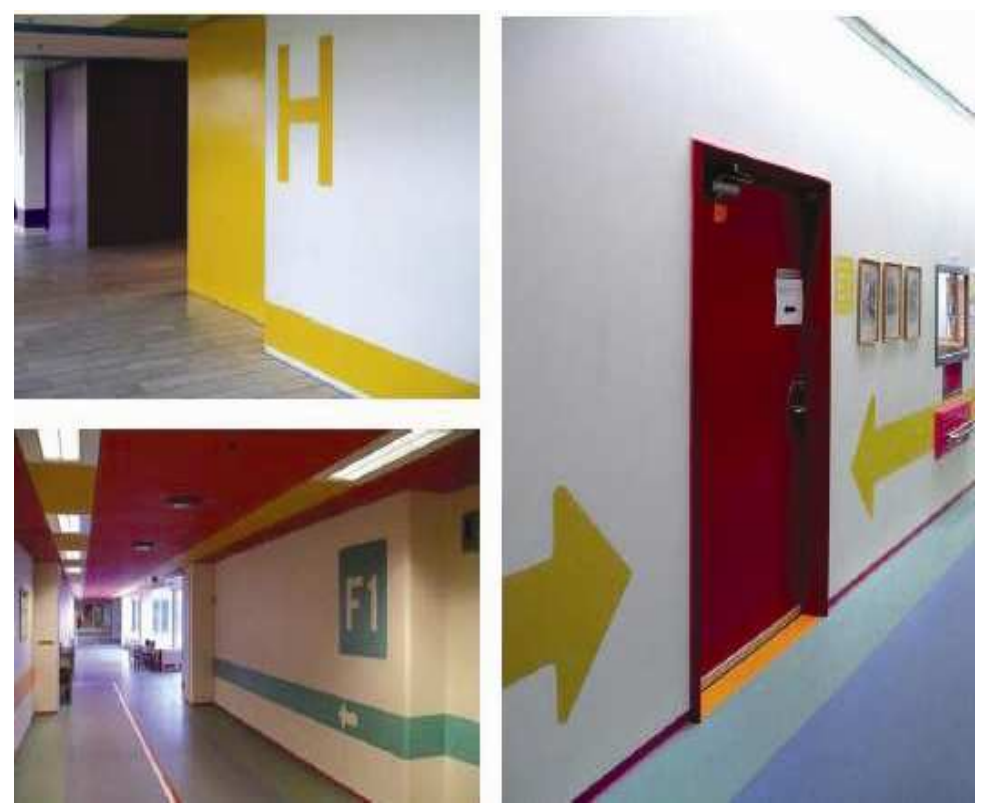

Figura 63 - Herlev Hospital, Dinamarca.

Demarcação de orientação e navegação. Fonte: Dalke; Matheson, 2007.
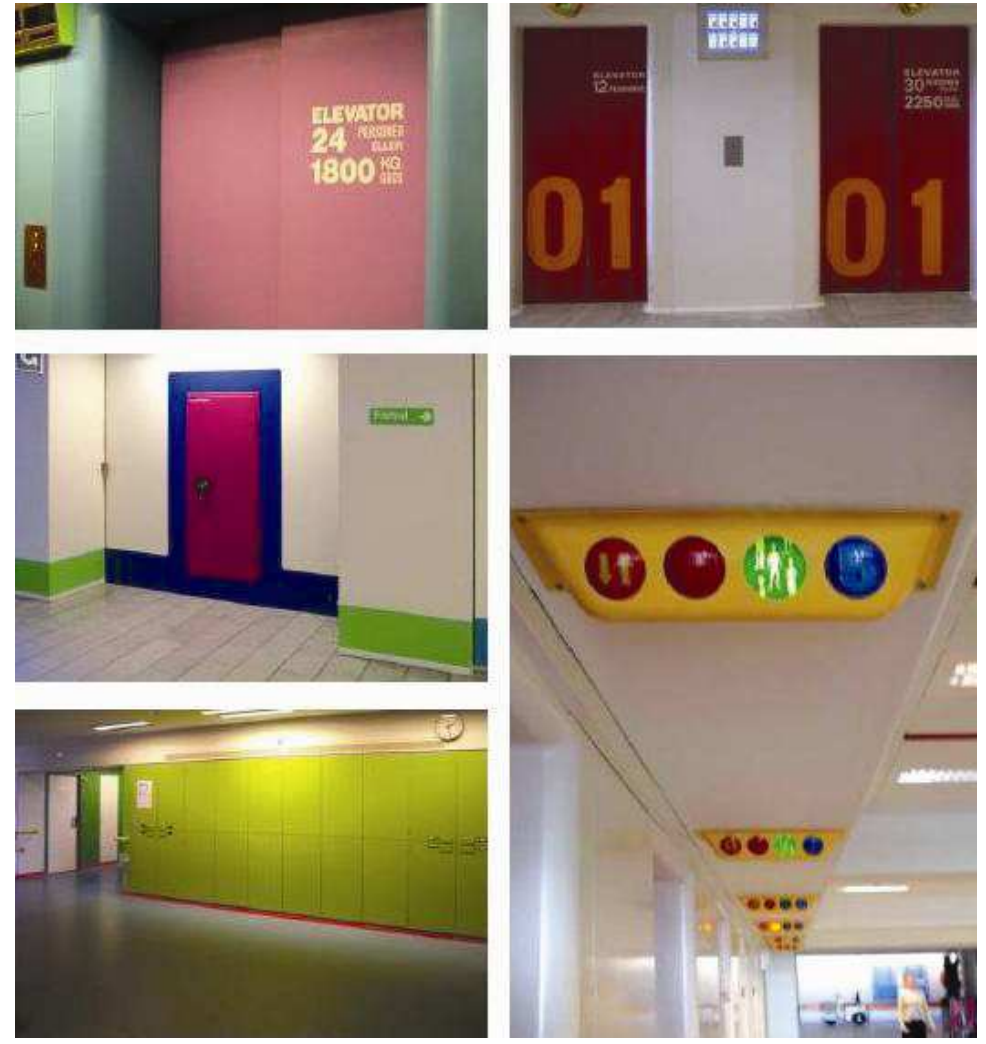

Figura 64 - Herlev Hospital, Dinamarca. Fonte: Dalke; Matheson, 2007. 


\subsubsection{Zoneamento}

O zoneamento de edifícios hospitalares consiste na divisão do espaço, em subáreas baseadas em critérios, como diferenciação de especialidades, tipos de atendimentos, tipos de serviços, entre outros. A cor como ferramenta para esse fim tem como aspecto fundamental a criação de uma identificação dessas zonas, facilitando a identificação dos serviços.

Dalke, Littlefair e Loe (2004) apontam que o zoneamento pode ser separado em blocos, em setores ou até mesmo em ruas internas. Também pode ser um método eficiente de ajudar na orientação e locomoção dentro do edifício hospitalar (Figura 64).

O tipo e local de aplicação das cores com essa finalidade podem ser bastante variados; compõem mapas ou estão incorporadas na ambientação ou em superfícies do ambiente. Um método muito utilizado é usar diferenciações de matizes em paredes e pisos, em que cada matiz refere-se a uma determinada área; outro método é a utilização das cores em detalhes de portas, bate-macas e rodapés para a demarcação dos setores.

Há a dificuldade em se utilizar, eficientemente, a codificação visual das cores como informação, de maneira a não se misturar com as cores do design, pois, como ferramenta visual de informação não deve anular ou prejudicar a aparência estética do ambiente. Para que a informação seja recebida e decodificada prontamente, as cores utilizadas, para esse fim, devem ser óbvias.

Partindo desses pressupostos, Dalke, Littlefair e Loe (2004) indicam que uma opção é escolher cores que se fixem rapidamente na memória, ou seja, cores conhecidas e mais populares como as cores do arco-íris; deve-se ainda levar em consideração que o número de cores utilizado deve ser o menor número possível.

\subsection{COMPOSIÇÃO DA PALETA CROMÁTICA}

Os arquitetos e designers hospitalar, cada qual, como constatado no levantamento da literatura, define seus próprios critérios que irão guiar as suas propostas 
cromáticas; uns seguem certas lei de harmonia das cores e outros, definições próprias. Também nota-se que na aplicação das cores, na arquitetura hospitalar, muitas recomendações estão baseadas em pesquisas empíricas. No entanto, independente da argumentação, método de concepção, o seu uso deve ser consistente, apresentando diretrizes claras, com objetivos e metas bem definidas. Com isso, facilita a escolha da paleta cromática e também repercutirá em um ambiente bem planejado, harmônico e com identidade cromática.

Com relação ao uso das cores, no ambiente hospitalar, Mahnke (1996, p. 148) apresenta uma lista com alguns objetivos que podem servir de guia para a aplicação da cor e da iluminação:

1.0 Deve preservar uma aparência digna e respeitável, sem deixar de ser atrativa;

2.0 As especificações das cores devem desempenhar um papel psicológico e estético, assim:

- Promover o processo de cura, preservando o bem-estar psicológico e fisiológico do paciente;

Com relação a esse aspecto, Feisner (2006, p. 133) esclarece que, ao longo dos anos, ocorre o amarelamento e escurecimento da lente e da córnea, e uma diminuição do tamanho da pupila, que causam consequências quanto à visão das cores; a quantidade de luz que atinge os fotorreceptores é reduzida, prejudicando a resolução visual. Uma característica do amarelamento da lente e da córnea, segundo Feisner, é o bloqueio seletivamente da luz de comprimento de onda curto, tornando a visão mais escurecida e os tons mais azulados; com isso, os idosos apresentam dificuldade em discriminar as cores que diferem em conteúdo de azul, como azul-claro, azul-anil, azul-petróleo, etc..

Assim, uma opção para auxiliar na orientação de espaços e de superfícies, como degraus, chãos ou portas, é o uso de contrastes cromáticos nesses elementos. Segundo Dalke, Littlefair e Loe (2004), também se pode usar esse tipo de composição em detalhes, gerando sensações de profundidade, com a criação de sombras. O contraste tonal, em superfícies adjacentes, torna mais explícitas as diferenças de superfícies; aumentando a visibilidade, no entanto, deve-se considerar 
que a leitura visual e espacial deve ser simples, tornando a imagem menos complexa.

- Ser uma ajuda para o diagnóstico médico, o desempenho cirúrgico e os serviços de terapia e reabilitação, proporcionando precisão visual;

Ao escolher a paleta cromática, deve-se levar em conta que alguns matizes são inapropriados para o uso em ambientes hospitalares, principalmente, nos ambientes de diagnóstico ou procedimentos médicos. Segundo Tofle et al. (2004), os matizes com conteúdos amarelos podem interferir, na avaliação do paciente, afetando a anamnese; por exemplo, o uso desses matizes em berçários, pode confundir um diagnóstico de icterícia de um recém-nascido.

Em relação a esse assunto, Robert Carr (2007) salienta que os pacientes convalescentes, frequentemente, estão com os tons da pele alterados, e o uso de certas cores e iluminações afetam ainda mais a sua aparência de palidez, portanto, segundo ele, recomenda-se o uso de luzes e cores quentes, para melhorar o aspecto do paciente.

O campo de visão de um médico, em cirurgia, geralmente, é o vermelho, do sangue; muitos autores, Dalke, Littlefair e Loe (2004), Tofle et al. (2004), Malkin (2008) e Mahnke e Mahnke (1996) recomendam, portanto, o uso da cor azul-esverdeada para o centro cirúrgico, inclusive para as roupas dos médicos e aventais e panos. Essa opção está baseada no fato de sendo a cor vermelha o campo de visão, o relaxamento ou descanso da visão se dá, na cor azul-esverdeado, sua complementar.

Outro fator que leva à escolha desse matiz é que, quando o vermelho do sangue entra em contato com o verde do tecido, juntas, anulam-se, produzindo um tom neutro, não afetando e nem se sobressaindo no campo visual cirúrgico. Na figura abaixo é possível verificar essas diretrizes. Na figura 65, a composição possui variedade de matizes azuis e verdes suaves, e sem brilho. 


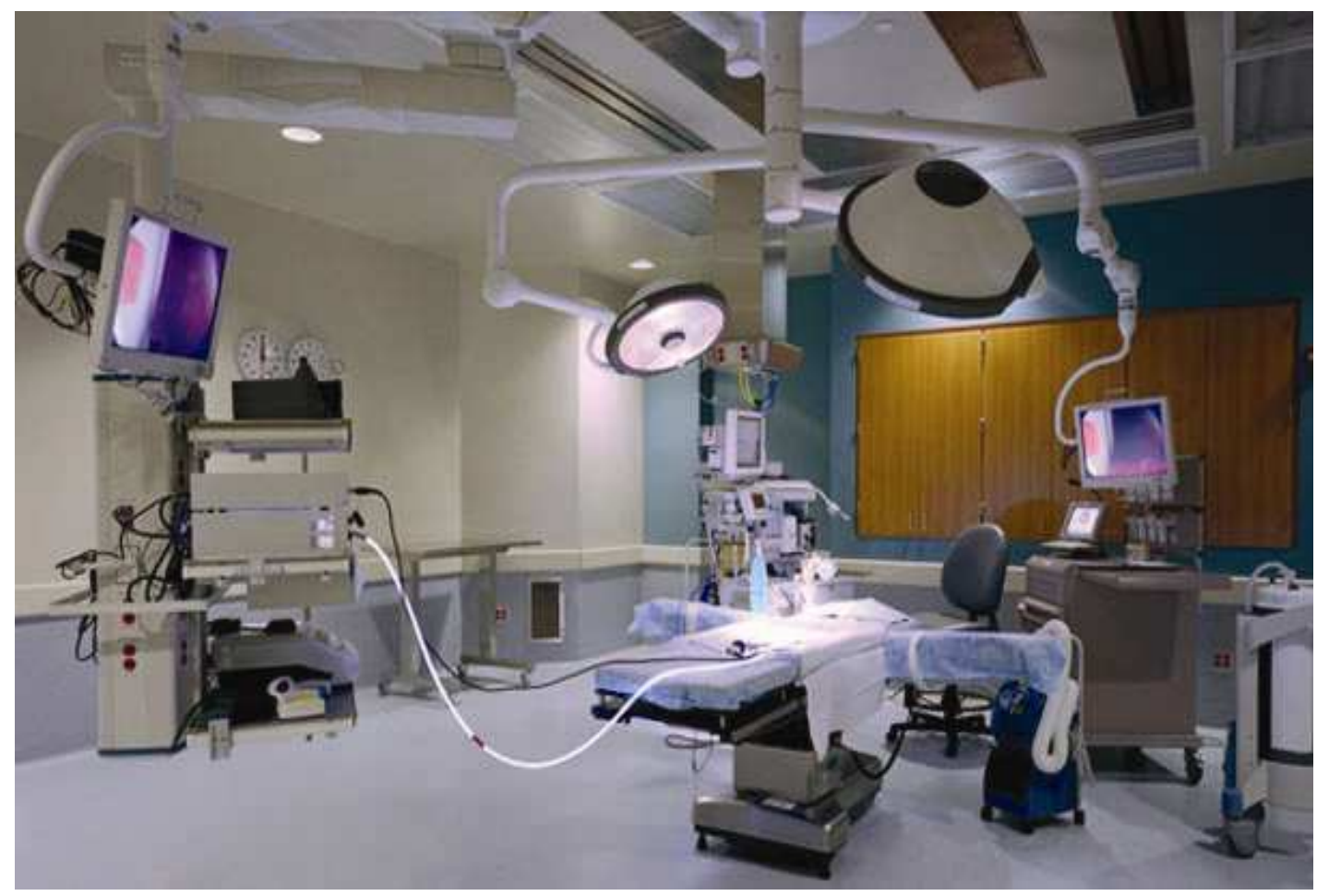

Figura 65 - Sala de Centro Cirúrgico. Providence Newberg Medical Center. Fonte: www.mahlum.com.

Para evitar que o ambiente projetado, neste caso a sala de cirurgia, tire a atenção do campo visual e cause problemas visuais, como ofuscamento, clarão e excesso de brilho, Hill (2008) recomenda que as refletâncias devam permanecer nos níveis adequados, que são: paredes - 40; piso - 15 e teto - 80, pois um dos maiores problemas apontados do ambiente cirúrgico é o combate ao excesso do brilho das luzes de alta intensidade; assim, usando matizes entre o verde e o azul, de baixa saturação e luminosidade, no ambiente, consegue-se a redução de brilho no campo de visão, além de criar um contraste visual adequado.

- Aumentar a iluminação, e a ergonomia visual, apoiar a orientação, prover a informação, definir áreas específicas, e melhorar as condições de trabalho, por meios dos visuais.

Esse aspecto especificamente já foi, em parte, anteriormente abordado, no entanto, vale ressaltar alguns pontos. As luzes refletidas das cores fortes ou saturadas, aliadas a uma determinada iluminação, podem interferir, na percepção espacial reduzindo o ambiente. Outra composição, por exemplo, pode causar ofuscamento da visão pela excessiva refletância das cores; equilibrar o uso das cores deve ser uma meta a ser buscada pelo arquiteto, designers e administradores hospitalares. 
Já foi repetidamente comprovado que o ambiente influi, no desempenho de produtividade dos serviços e no sentimento de bem-estar. A ergonomia visual ou conforto visual deve ser uma das primeiras preocupações e deve, sem dúvida, guiar as diretrizes de escolha e aplicação das cores. Portanto, obter o equilíbrio cromático é uma das soluções para essa diretriz. Para Minah (2008) o equilíbrio cromático depende do tamanho, da forma e da área revestida; entre outros aspectos levantados por ela, estão o entorno, o material e a textura.

3.0 A iluminação deve ser escolhida respeitando as funções, como reforço psicológico, atração visual, capitulação cromática e com preocupações biológicas.

Entorno da iluminação, mesmo não sendo um tema a ser aprofundado nesta dissertação, há aspectos de importância para a percepção cromática. Já foi apresentada uma breve compilação sobre as principais influências da iluminação na percepção cromática, ressaltando a importância da composição integrada desses dois elementos que, juntos, promovem o conforto visual, e que podem ainda auxiliar no processo terapêutico.

Esses aspectos levantados por Mahnke (1996, p. 148) como principais diretrizes para o uso das cores, no ambiente hospitalar, podem ser ampliados ainda mais. César (2003) acrescenta à lista mais dois pontos importantes que devem ser levados em consideração, na escolha da paleta cromática: a manutenção e a assepsia.

Para o fator manutenção, leva-se em conta a própria manutenção das cores, além da aquisição de material. Nota-se, na literatura levantada, que a indicação de vários autores é que se tenha um número reduzido de cores, por exemplo, de tintas para pintura das paredes; se recomenda que, para cada área, se use um número limitado de cores para compor a paleta cromática e, das quais, $80 \%$ sejam de cores suaves.

No entanto, Malkin (2008) mesmo concordando com essas indicações, ressalta que a composição com um número reduzido de matizes não deve comprometer a qualidade da variedade cromática no ambiente. A variedade cromática deve ser constante, além de se ter variados níveis de iluminação. 
Como visto ao decorrer da dissertação, a monotonia, pela falta de estímulos visuais, causa um ambiente passivo e monótono. Segundo Dalke, Littlefair e Loe (2004), usar desses recursos aumenta a experiência visual, enriquecendo a vivência e mantendo em alerta a excitação e o interesse.

Na figura abaixo, o posto de enfermagem utiliza-se das múltiplas funções das cores. A criação de sombras e perspectiva é conseguida pela variedade de matizes e texturas, com contrastes de luminosidade. As cores apoiam a orientação e a informação, como, por exemplo, pela demarcação de portas e definição de áreas específicas. Também equilibra os níveis de iluminação do ambiente, por possuir uma composição cromática de cores pouco saturadas, com baixa luminosidade e contrastes de brilho bem definidos.

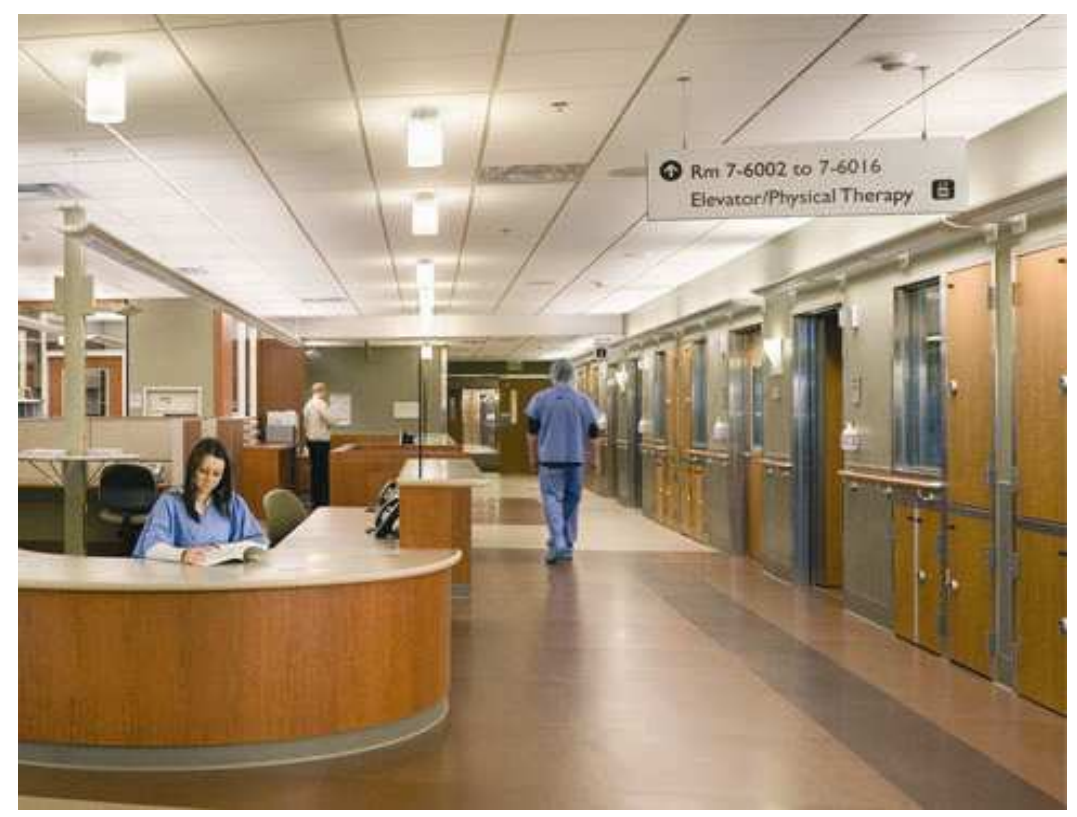

Figura 66 - Posto de enfermagem. - Evergreen Medical Center. Fonte: www.mahlum.com.

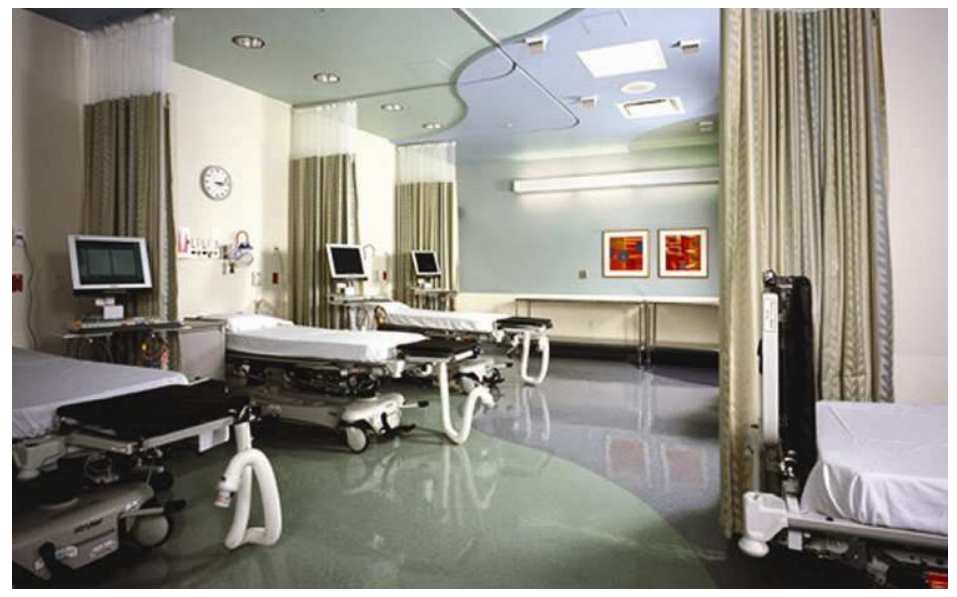

Figura 67 - Sala de recuperação - Evergreen Medical Center. Fonte: www.mahlum.com 
Já na figura anterior (Figura 67), a composição cromática com cores suaves de baixa refletância proporciona conforto visual e um design com qualidades estéticas, como pode ser visto no detalhe do teto. O conforto é obtido com a ausência de ofuscamentos e contraste moderado de luminosidade e brilho, em suma, uma composição com variedade de estímulos.

\subsubsection{Diretrizes para a composição cromática}

Ao se propor uma composição cromática para um ambiente, todos os elementos do ambiente interno devem ser considerados e analisados para, juntos, comporem a paleta cromática, pois, a somatória das características desses elementos resultará no aspecto final do ambiente. Para as diretrizes atuais de humanização do ambiente hospitalar, e com os objetivos pretendidos mencionados ao longo da dissertação, é imperativo que, em um hospital, a ambientação cromática seja harmônica e favorável a tal meta.

Dalke, Littlefair e Loe (2004) e Tofle et al. (2004) ponderam que a escolha da paleta cromática não deve estar baseada em gosto pessoal ou preferências de cores, ou por suas qualidades psicológicas e por aspectos emocionais relacionados a elas. $O$ estudo e levantamento das preferências de cores, no entanto, podem guiar a algum tipo de indicação, como, por exemplo, cores em determinadas culturas ou tradições que são consideradas tabus, ou inapropriadas, decorrente de associações feitas (CÉSAR, 2003; MALKIN, 2008).

As considerações acima apresentadas são encontradas, na maioria dos autores levantados, que concordam que trabalhar somente no campo subjetivo das reações humanas frente às cores é arriscado, além de não possuir concretamente resultados plausíveis que suportem consideravelmente essa aplicação. Muitos justificam que tais relações, como as cores e as emoções, dependem de circunstâncias culturais, e associações regionais, variando conforme as tradições.

A escolha por uma determinada paleta pode ser justificada pelos efeitos perceptivos, como aumento e diminuição das sensações de volume, dimensão, senso de tempo, entre outros, entretanto, notou-se que, usualmente, os arquitetos ou designers de ambientes hospitalares, embasam suas escolhas em pesquisas empíricas, 
principalmente as que relatam relações com o desempenho e produtividade dos serviços. Contudo para Mahnke e Mahnke (1996), Malkin (2008), Tofle et al. (2004) e Costi (2002), optar pelas leis de harmonia das cores é uma medida segura para a escolha da paleta cromática, auxiliando inclusive a aplicação da mesma no ambiente.

Partindo das considerações que a escolha e aplicação das cores, no ambiente hospitalar, devem ser regidos pelas leis de harmonia das cores, tais composições são possíveis com esquemas de diversas formas; por meio de composições mistas; mesmo matiz e variações de luminosidade ou saturação, saturações variadas e mesma luminosidade, vários matizes e mesmos valores de luminosidade. Contudo, Caivano (2004) salienta que para tanto, o conhecimento das leis de harmonia das cores deve ser aprofundado, e seu desenvolvimento baseado em análises do círculo das cores.

Esse assunto é levado à extrema importância para Malkin (2008) que conclui, afirmando que os arquitetos e designers hospitalares devem conhecer e terem entendimentos dessas leis; ela considera esse um grave problema na formação desses profissionais, que não possuem, ainda na universidade, o necessário aprendizado, sendo um ponto fraco das escolas, ela ainda salienta que esse tema não é levado com a devida seriedade que merece, Tofle et al. (2004) também compartilham dessa visão.

\subsubsection{Harmonia das Cores}

Segundo Costi (2002, p. 92): "[...] a lei fundamental de toda a harmonia cromática, que caracteriza cada cor como estimuladora de efeitos sensíveis e morais, é a que, para se revelar plena, solicita sempre sua complementaridade".

Nessa visão de Costi, pode-se notar uma relação com a teoria das cores de Schopenhauer (2003). Para ele, a cor, quando vista pura como, por exemplo, o vermelho verdadeiro, significa que as metades qualitativas da retina são iguais, e então reproduzem esta cor; quando desiguais, produzem as inúmeras possibilidades de cores possíveis, pois, segundo sua teoria, a cor é a atividade qualitativamente dividida da retina. Para ele, após cada cor ser manifestada, sucede seu 
complemento residual, no olho, no sentido de uma atividade plena da retina, que ele define como espectro fisiológico. Logo, considera que a verdadeira teoria das cores deve ser sempre com pares cromáticos.

Costi (2002) apresenta algumas relações de composição cromáticas possíveis, embasadas pela lei de harmonia das cores.

- Harmonia por Analogia: consiste na harmonia entre cores sob a influência de uma cor em comum, sendo essa a dominante, e outras adjacentes a essa com 0 papel de enriquecer a composição. Segundo Mahnke e Mahnke (1996), essa relação existe quando não se usa mais que três cores próximas umas as outras, tendo em comum um matiz. Por exemplo, vermelho, laranja e amarelo. A composição cromática embasada por essa lei oferece maior variedade cromática e de estímulos.

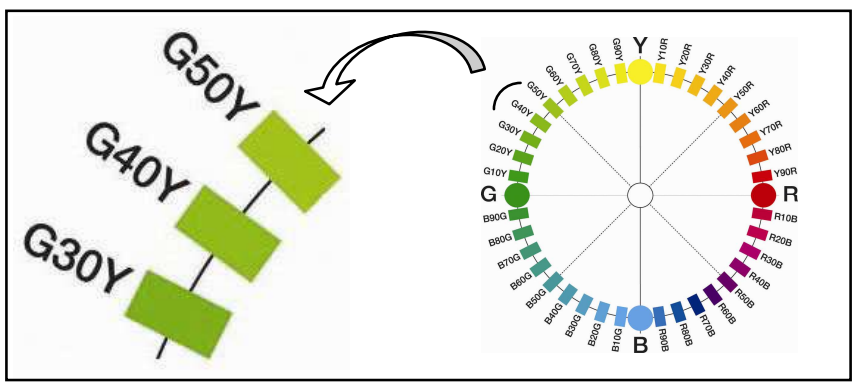

Figura 68 - Harmonia por analogia. A partir de cores do sistema cromático NCS.

Fonte: NCS modificado pela autora.

- Harmonia por Complementaridade: é a relação que se dá entre cores diretamente oposta no círculo das cores; é a harmonia que ocorre quando combinamos cores que se encontram simétricas em relação ao centro do círculo das cores. Mahnke e Mahnke (1996) salientam que esse tipo de harmonia representa uma harmonia de contraste.

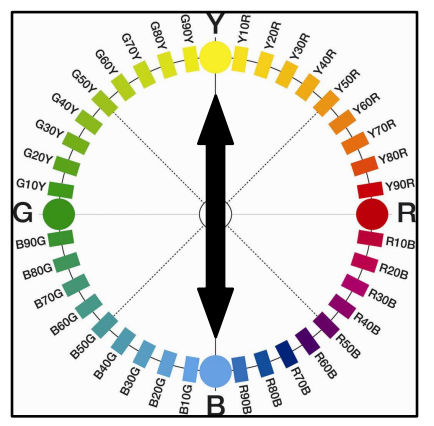

Figura 69 - Harmonia por cores opostas.

A partir de cores do sistema cromático NCS.

Fonte: NCS modificado pela autora. 
Mahnke e Mahnke (1996) consideram essa uma das melhores relações existentes para a harmonização de ambientes, pois se utiliza as duas metades do círculo das cores, ou seja, uma está, no lado das cores quentes, e a outra, obrigatoriamente, está, no lado das cores frias, por exemplo vermelho e verde, ou azul e amarelo (CAIVANO, 2004), e segundo eles, deveria servir de base para o design de interiores.

- Harmonia por Tríade: consiste em uma relação de composição com três cores equidistantes no círculo de cores. Por exemplo, azul, amarelo e vermelho. Para Caivano (2004), essa relação proporciona uma combinação visualmente atraente, por apresentar um alto contraste visual, ao mesmo tempo em que mantém o equilíbrio das cores.

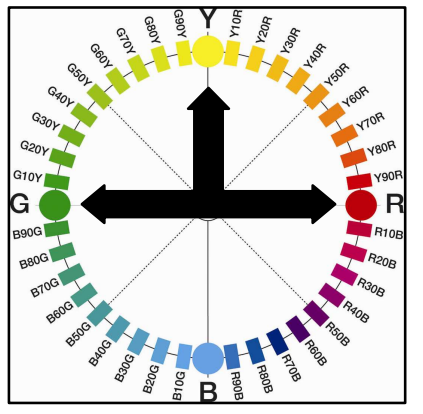

Figura 70 - Harmonia por tríade. A partir de cores do sistema cromático NCS.

Fonte: NCS modificado pela autora.

- Harmonia Monocromática: é uma composição de um único matiz com diferentes intensidades, ou seja, é a relação que utiliza variações de luminosidade e saturação de uma mesma cor. Essas harmonias produzem um efeito simples e elegante, no entanto, como firma Malkin (2008), resulta em um ambiente neutro, onde passa a ser difícil ressaltar os elementos mais importantes.

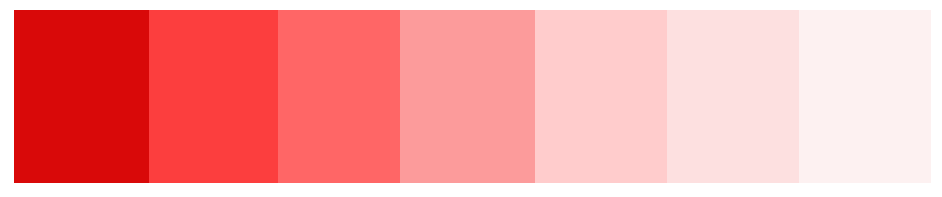

Figura 71 - Escala Monocromática. Fonte: Anne Matarazzo.

Mahnke e Mahnke (1996) consideram que esse tipo de harmonia cria ambientes monótonos; mesmo compartilhando dessa visão, Dalke, Littlefair e Loe (2004) consideram esse um esquema de cor harmonioso para os ambientes hospitalares, podendo haver variedade dos locais de aplicação. 
Como exemplo, eles citam um esquema tonal onde se use um azul profundo para uma porta, e um mesmo azul com branco, como um matiz pálido para as paredes, e a escolha de um piso, no qual, se tenha um tom azulado escuro, com médiasaturação, e manchas claras. No entanto, eles reconhecem que para ambientes de longa permanência, a composição monocromática não é satisfatória, em que se deve buscar maior variedade de matizes, mas, se usada como pano de fundo para uma composição que utilize tons brilhantes de outras cores, pode resultar em um ambiente interessante e estimulador.

Arnheim (1995) afirma que quando se utiliza a harmonia monocromática em um ambiente, em que se isola uma cor em particular, os valores psicológicos relacionados a ela são ressaltados.

- Harmonia Acromática: é a harmonia baseada na composição de cores sem saturação como a branca, a preta e a cinza.

- Harmonia por Contraste: existem vários métodos de harmonia por contraste, o mais conhecido consiste em empregar várias cores e saturação e valores de uma mesma cor.

\subsubsection{Contrastes de Cores}

O uso de contrastes de cores, no ambientes, é sem dúvida, um dos assuntos mais discutidos pelos estudiosos da área. Não é de se estranhar que haja uma supervalorização dessa técnica para a composição cromática de ambientes hospitalares; tal fato pode ser percebido, em Mahnke e Mahnke (1996), que o ressalta enfaticamente, considerando o contraste a base do design eficiente.

A caixa de ferramentas de todas as comunicações visuais são os elementos básicos, a fonte compositiva de todo tipo de materiais e mensagens visuais, além de objetos e experiências [...] A cor, a contraparte do tom com o acréscimo do componente cromático, é o elemento visual mais expressivo e emocional [...] A mais dinâmica das técnicas visuais é o contraste, que se manifesta numa relação de polaridade com a técnica oposta, a harmonia. (DONDIS, 1997, p. 23). 
A importância do contraste para as composições cromáticas como também, para as percepções espaciais como um todo está na criação de estímulos visuais, que segundo Malkin (2008) são conseguidos por meio dessa técnica e que possibilita a distinção de formas, volumes, entre outros elementos do espaço.

Vernon (apud MAHNKE; MAHNKE, 1996, p.6, tradução nossa), psicólogo Inglês, em uma de suas passagens, apresenta, muito claramente, a importância dos estímulos:

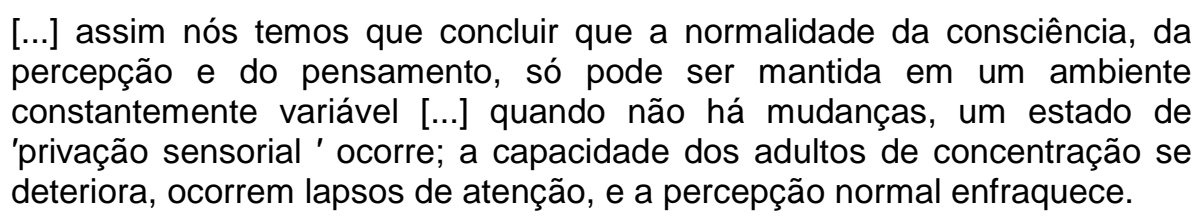

No livro A Visual Reference for Evidence-Based Design, Malkin aprofunda essa discussão sobre a privação sensorial, decorrente da falta de estímulos. O senso visual, conforme apontam Karin Anter, James J. Gibson e Anders Liljefors, reage a contrastes, e não, a composição de comprimento de onda ou a intensidade da radiação; explicando, psicofisicamente, a importância dos contrastes.

Para Guzowski (1999), além da privação sensorial, outro aspecto decorrente da falta de contraste é a fadiga, o cansaço físico e mental, tanto dos pacientes como do corpo clínico, e é particularmente acentuada, pela monotonia do ambiente. A fadiga é apontada por Baughan-Young (2001) como um dos principais problemas do ambiente hospitalar, e relaciona sua causa a quatro fatores principais.

O primeiro fator é o excesso de superfícies altamente reflexivas, ou seja, brilhantes (Figura 73), que causam tensão; outro fator é a monotonia, conforme cita: "[...] o uso de apenas uma cor faz o olho criar uma 'pós-imagem' (a cor oposta aquela) levandoo a uma ação muscular excessiva" (BAUGHAN-YOUNG, 2001, tradução nossa, grifo do autor). Assim como também, o uso de padrões, terceiro fator, que segundo ele, faz com que o olhar seja constantemente desviado. E, por último, mas não menos importante, relaciona-se às constantes mudanças visuais, nos padrões de iluminação e/ou cromático, forçando a musculatura dos olhos expandirem e contraírem, levando a fadiga. 


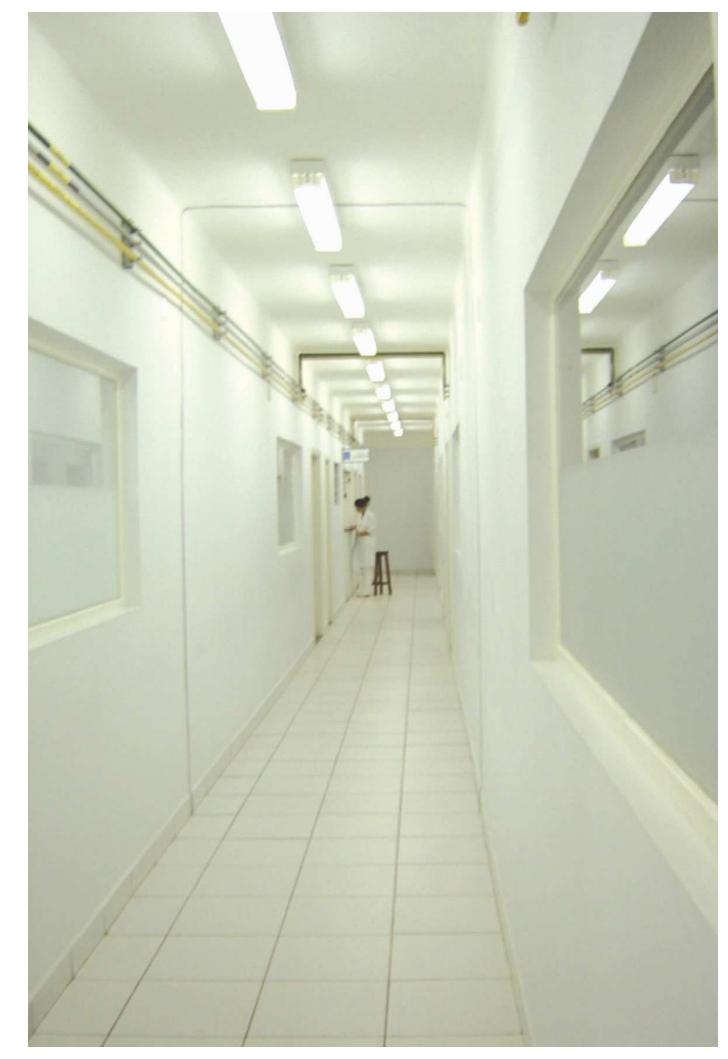

Figura 72 - Corredor da ala de internação - FUST. Fonte: Anne Matarazzo.

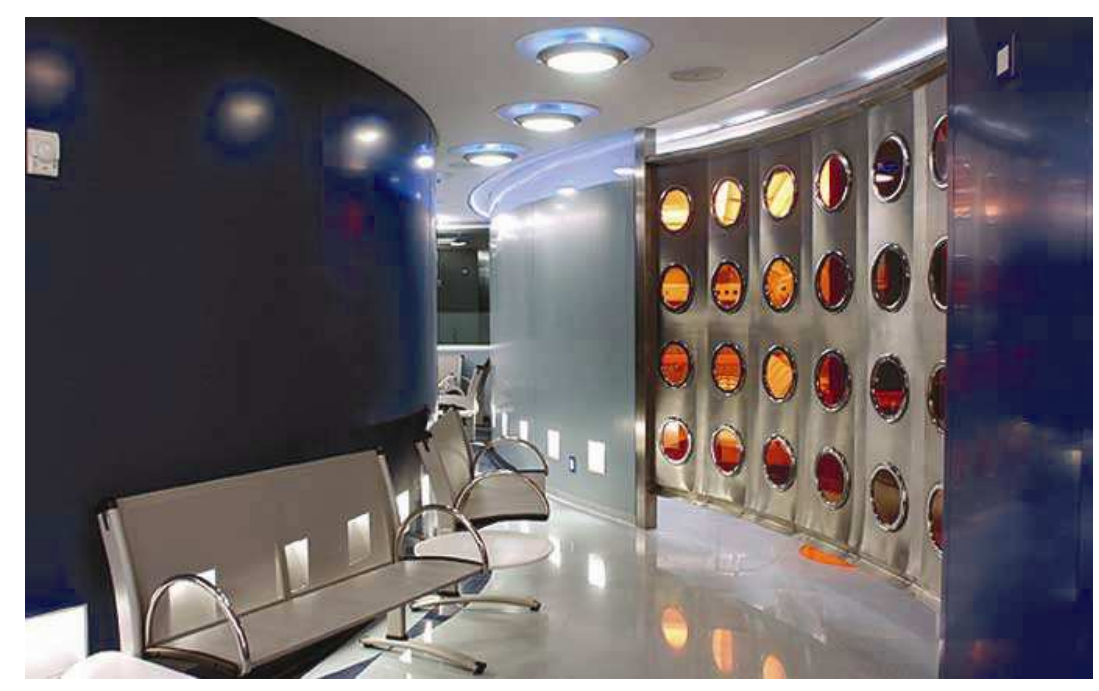

Figura 73 - Espera - Emergência. Hospital Paulistano, São Paulo. Fonte: Grunow, 2002.

$\mathrm{Na}$ Figura 72, a monotonia do ambiente decorrente do uso de somente uma cor, representa o ambiente com privação total de estímulos visuais. Portanto, para combater a fadiga e a monotonia, a variedade (contraste) deve estar presente no esquema cromático do ambiente hospitalar. Também, Spivack (apud TOFLE et al., 2004, p. 53) considera o contraste como fonte de estímulo, atraindo a atenção visual; o contraste de cor e tom, segundo ele, deve ser usado quando se desejar 
definir e tornar nítidos os volumes e as formas, além de demarcar mudanças de planos; Dondis (1997) complementa que, sendo o contraste tonal responsável pela percepção desses padrões nos objetos, seu uso facilita a percepção espacial, por simplificar a leitura dos objetos.

A técnica do contraste, como estratégia visual, não só possui a capacidade de atrair e estimular a atenção, como também de aguçar o significado; e podendo ainda dramatizar esse significado, para torná-lo mais importante e mais dinâmico (CAIVANO, 2004; DONDIS, 1997). Um esclarecimento é feito por Beck et al. (2007), eles levantam uma distinção importante entre dois conceitos que influenciam tanto a técnica de composição como o resultado final. Eles definem contraste como a separação nítida entre duas ou mais cores e, por intensidade, o encontro entre cores suaves e cores fortes. Mas conforme encontrado nos demais autores, ambos os conceitos constituem contraste.

Para a criação de contrastes, Dondis (1997, p. 125) estipula duas relações: a primeira é o uso do tom, que para ele é a dimensão da cor predominante, pois considera que é o atributo que "[...] possui maior relação com meio ambiente [...]", e a segunda, que considera a mais importante, é a divisão das cores em quentes e frias. Com relação à composição de contrastes, a partir do uso de cores complementares, Dondis aponta que, ao serem justapostas, as complementares fazem com que cada uma delas chegue a sua intensidade máxima. Ainda segundo ele, como a cor complementar causa uma busca de neutralidade, o contraste combate essa tendência de redução dos estímulos e das supressões cromáticas.

No entanto, o exagero ou altos contrastes devem ser evitados. Segundo Costi (2002), não deve haver um ambiente onde se tenha um lado muito claro e outro muito escuro, devendo-se buscar luminosidades iguais, mesmo de diferentes matizes; entretanto, Caivano (2004) defende o uso de altos contrastes quando se deseja definir volumes, formas, ou mudanças de planos e contornos, sobretudo, em ambientes grandes com texturas lisas, e cujo tempo de permanência, seja curto. Segundo ele, esse tipo de composição resulta em um ambiente excitante. 
A figura abaixo (Figura 74) representa um exemplo de contraste de intensidade (cores suaves com cores saturadas), com diferentes valores de luminosidade. A composição se utiliza de cores quentes e cores frias, no entanto, o resultado final é um ambiente de alta luminosidade e brilho.

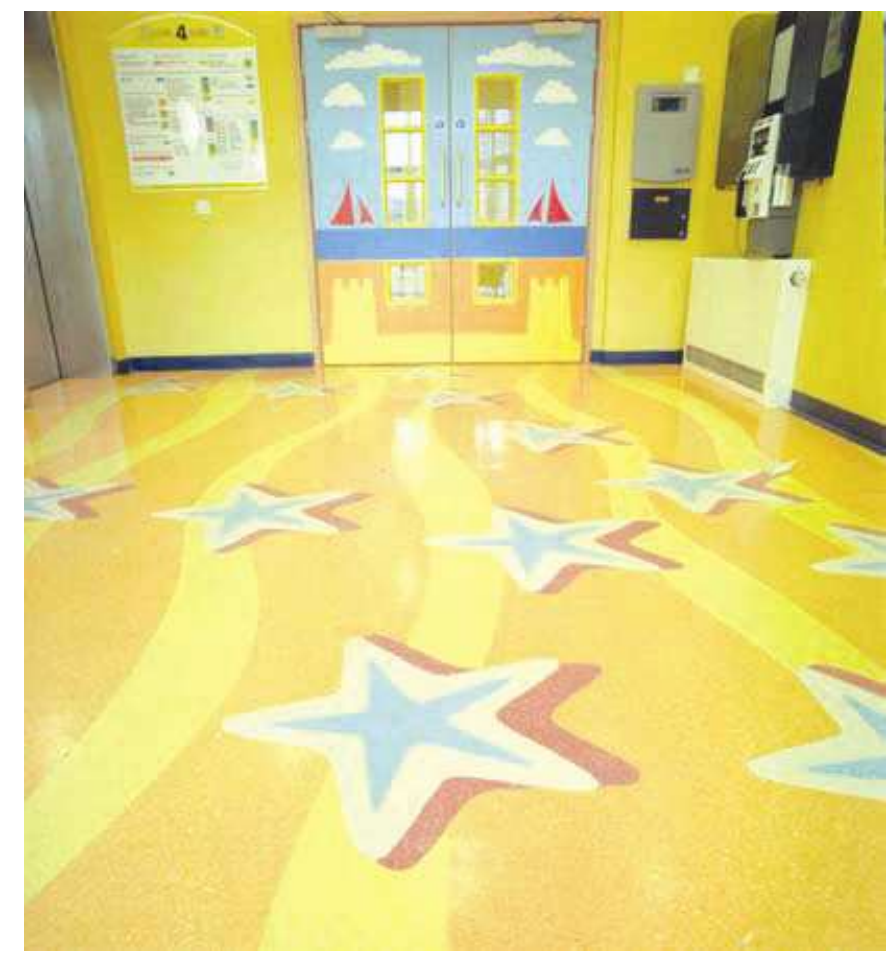

Figura 74 - Lobby - Bristol Royal Hospital of Children, Reino Unido. Fonte: www.publicartonline.org.uk/casestudies/health/brch/images.php.

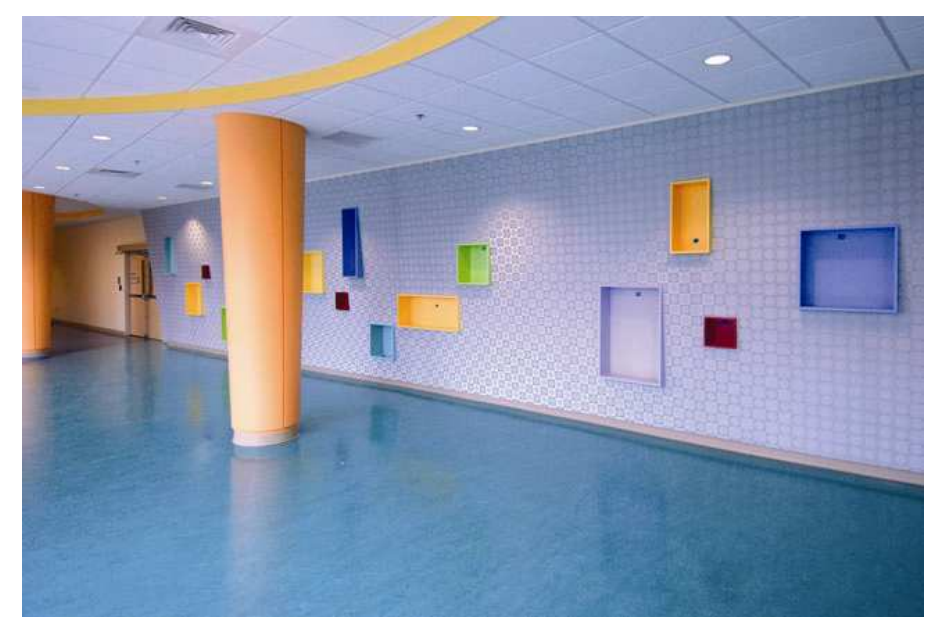

Figura 75 - PSE\&G Children's Specialized Hospital, Nova York. Fonte: www.hksinc.com/healthcare

A figura acima (Figura 75) ilustra um ambiente que possui uma composição cromática de contraste entre cores saturadas e cores suaves, e ambas com variados valores de luminosidade, também compõe o contraste o uso de matizes quentes e 
frios. Tal composição cria pontos de interesse (pilares e pontos na parede), brilhantes de maior destaque, proporcionando um ambiente estimulante e visualmente dinâmico.

Os altos contrastes, principalmente de brilho, devem ser evitados por causa o ofuscamento e por provocar a diminuição da capacidade de visão; Farina (2006) explica que essa diminuição ocorre devido à necessidade de adaptação da retina às mudanças bruscas de níveis de iluminação e, que geralmente leva certo tempo.

Do ponto de vista de composição cromática, não se deve perder de vista uma das principais diretrizes apontadas por Mahnke (1996) para o ambiente hospitalar, a de proporcionar a precisão visual, em outras palavras, em manter adequados os níveis de conforto visual; assim, o uso de contrastes deve ser estudado e planejado de maneira a não prejudicar e a sustentar as atividades a serem desempenhadas naquele ambiente.

Conforme aponta Baughan-Young (2001), a razão ideal de contraste é de 3 a 1, em uma distribuição uniforme de iluminação. "[...], por exemplo, o branco tem um valor de $90 \%$ de luz reflexiva, e o preto tem $5 \%$. Isso faz com que a relação seja de 18 a 1 - longe do ideal [...]", Farina (2006) acrescenta que a fisiologia mostrou que contrastes, na ordem de 1:5, provocam a diminuição da capacidade de visão.

Em relação ao conforto visual, Scarazzato (apud COSTI, 2002, p. 136) menciona: "[...] é obtido quando se é capaz de perceber, da melhor forma possível, as informações que, instintivamente ou conscientemente se quer receber [...] exercer as atividades visuais com o máximo de precisão e segurança, e com o menor esforço".

O uso de contraste como técnica visual é, por assim dizer, uma estratégia inteligente para manter o estímulo, facilitar a leitura espacial e manter a variedade cromática. $\mathrm{O}$ ambiente hospitalar por meio de sua arquitetura e design deve promover o bemestar em todos os níveis dos diversos usuários, e contribuir o máximo possível para aliviar as tensões pré-estabelecidas na relação ambiente $\mathrm{x}$ ser humano, se usandose dessa técnica o usuário é instigado a sair de seu stress, de seus medos e partir para novas descobertas, pela experimentação da arquitetura, sua missão está sendo cumprida. 
O uso de contrastes na composição cromática de um ambientes pode ocasionar mudanças na percepção cromática, ou seja, mudanças nas cores das superfícies percebidas; na relação de contraste, as cores influem umas sobre as outras, de forma a comporem uma terceira relação, e consequentemente, outra percepção cromática e espacial; essa característica é descrita por Itten (apud Caivano, 2004) para explicar o fato de que as cores sempre estão em composição com outras influências cromáticas de maneira tais, que nunca são vistas puras nos ambientes.

\subsubsection{Contraste Sucessivo e Simultâneo}

O contraste simultâneo, descrevendo o fenômeno da modificação que as cores parecem sofrer dentro da composição física e na saturação de cada cor, sempre que vistas simultaneamente. $O$ contraste sucessivo das cores. Fenômeno observável a partir da saturação dos olhos pela cor de um ou mais objetos, onde ao se deslocar o olhar, as imagens destes objetos são identificadas com a cor complementar a cada uma delas. (CHEVREUL apud SILVEIRA, 1994, p.15, tradução nossa).

Segundo Silveira (1994), o primeiro a definir tais fenômenos foi o químico francês, Michel-Eugène Chevreul, em seu livro intitulado Da lei dos Contrastes Simultâneos das Cores, de 1839; Chevreul influenciou fortemente as artes visuais dos séc. XIX e XX.

Para que existam os efeitos do contraste simultâneo, que consiste nas modificações de percepção que sofrem duas superfícies diversamente coloridas, as cores devem estar presentes em uma mesma composição. Segundo Caivano (2004), esse efeito produz uma impressão de dinamismo e variedade, mesmo que não haja muitas variantes de cores.

Ele ainda salienta que se pode usar desse tipo de contraste quando se desejar produzir efeitos de acentuação ou diminuição de luminosidade de um matiz. Já que esse efeito produz, em cores complementares, um efeito de ressaltar suas características, ou seja, uma cor poderá parecer mais saturada e mais brilhante (Figura 76 e 77). 


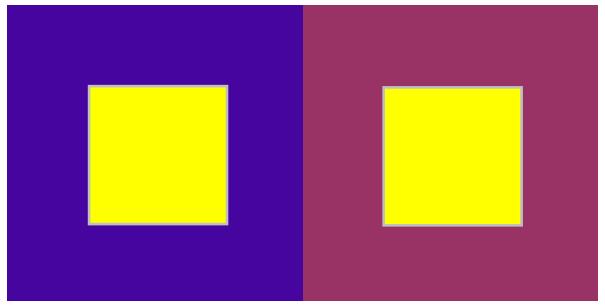

Figura 76 - Contraste de brilho.

Fonte: Anne Matarazzo.

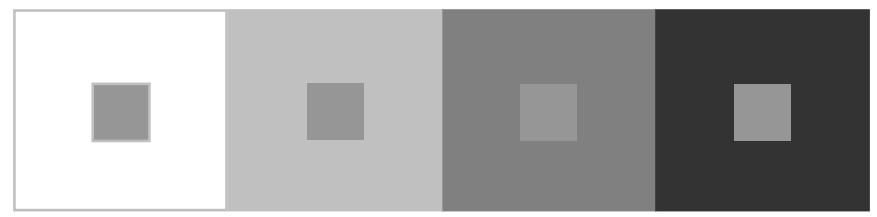

Figura 77 - Representação do Contraste Simultâneo. Fonte: Anne Matarazzo.

Já o contraste sucessivo ocorre quando, após receber o estímulo de uma cor de um objeto, modifica-se a percepção de outro objeto. Em outras palavras, após certo tempo sob o estímulo de um matiz em particular, os olhos tendem a se adaptar ao estímulo, e ao se interromper o estímulo e se olhar para uma outra superfície, branca ou cinza, a cor complementar daquele matiz aparecerá, efeito demonstrado na figura 78; esse efeito é chamado de after-image (pós-imagem), e pode ser explicado como uma fadiga ou esgotamento dos receptores daquele estímulo (MAHNKE; MAHNKE, 1996), fundamentada pela teoria tri-cromática.

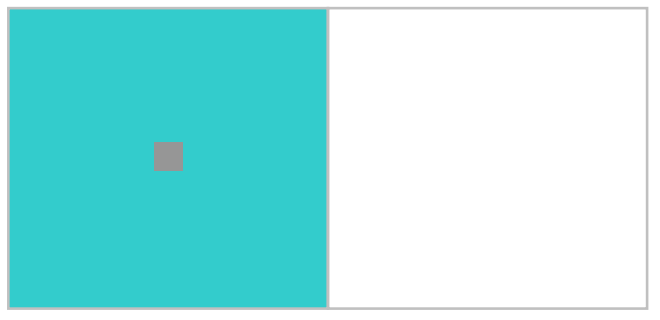

Figura 78 - Representação do Contraste Sucessivo. Fonte: Anne Matarazzo.

Como esses fenômenos englobam diversos conceitos relacionados às cores, vale ressaltar algumas diferenças conceituais, para que se torne claro tal processo, e que aumente a compreensão que a percepção da cor é fruto das relações entre as suas várias características e atributos. Assim, por contraste, pode-se entender como uma função da luminância, que como visto, é a intensidade de energia luminosa recebida pela retina. E o conceito de brilho, como já disse Michel (1995), é uma relação de comparação entre superfícies iluminadas, portanto, o brilho ocorre quando há percepção de contrastes. 
Por fim, vale ressaltar que todos os contrastes, tanto os sucessivos quanto os simultâneo são usados como um recurso para "[...] modificar a identidade das cores ou a forma como elas nos impressionam" (CAIVANO, 2004, p. 17, tradução nossa).

Ao ocorrer esses fenômenos, ambas as cores tendem a perder um pouco de seu brilho, no entanto, com cores complementares, intensifica-se uma a outra; efeito que pode ser minimizado quando existir um alto contraste de brilho entre as cores. Segundo menciona Caivano (2004), quando dois matizes estão adjacentes, um projeta no outro a cor complementar (contraste sucessivo), e esse recurso pode ser usado para criar ambientes vivos e atrativos.

\footnotetext{
Estes contrastes e efeitos derivados, da interação das cores têm uma grande importância desde o ponto de vista estético e, certamente, foram utilizados nas artes para criar situações perceptuais que vão além da realidade física dos estímulos que as produzem. (CAIVANO, 2004, p. 16, tradição nossa).
}

É desejável que o ambiente hospitalar proporcione um ambiente, onde enriqueça a experiência do ser humano, inclusive visual, mas principalmente, sensorialmente, e que seja participativo, no processo terapêutico de cura, e instituidor de sensações positivas e de bem-estar, que como já visto, é alcançado por meio de um design que, sobretudo proporcione variedade de estímulos. E, nesse ponto, é que a importância do contraste reside. Conhecer seus funcionamentos e características é fundamental para 0 arquiteto ou designer hospitalar, mostrando seu comprometimento com o resultado final.

\subsubsection{Características das Cores: Indicações para a Composição da Paleta Cromática}

A paleta de cores para as composições pode ser inúmera; para compor um esquema cromático um recurso é utilizar-se das características das cores, tais como seus atributos ou suas características de aparência. As cores podem ser classificadas de brilhantes, luminosas, saturadas, suaves, entre outras, ou denominadas de quentes e frias. Ao longo dos Capítulos Três, Quatro, Cinco e Sete foram apresentadas e discutidas algumas dessas classificações e denominações, que estão relacionadas às suas características físicas e perceptivas. 
Neste sentido, serão apresentadas considerações gerais sobre os usos e aplicações das cores na arquitetura. As indicações apresentadas são decorrentes de uma compilação da literatura revisada, voltando-se para o ambiente hospitalar, com o intuito de auxiliar a composição dos esquemas cromáticos para esses ambientes. Essas são recomendações que em hipótese alguma representam padrões ou guias de aplicação, somente indicam direções, frutos de inúmeros estudos e pesquisas.

\subsubsection{Cores Frias}

Deve ser evitado o uso, das cores denominadas frias, para pacientes com histórico de histeria, hipertensão e/ou ansiedade, apontam Tofle et al. (2004). Segundo César (2003), como as cores frias estão relacionadas à aceleração de tempo estimado, elas são recomendadas para ambientes onde se desenvolvem atividades monótonas, ainda em relação a essa característica, Caivano (2004) indica seu uso em ambientes que se tenham atividades que requerem esforço físico.

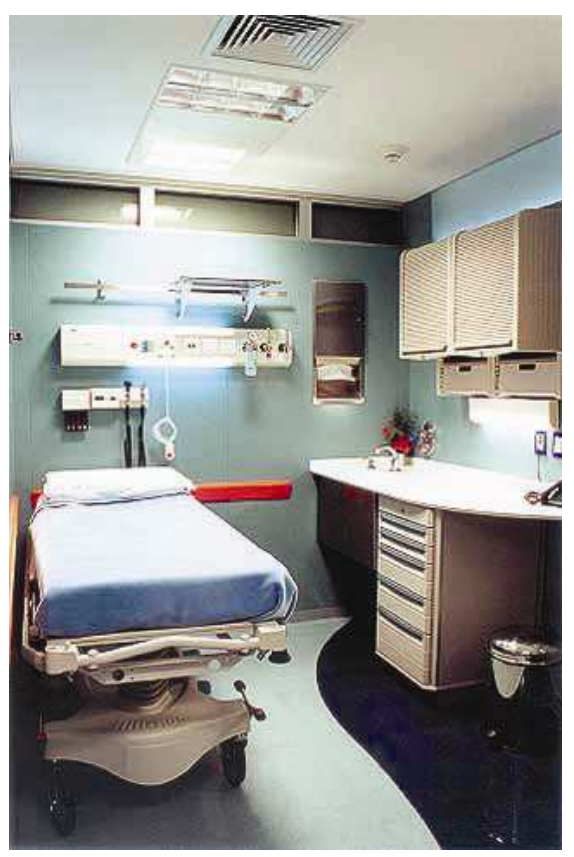

Figura 79 - Hospital Paulistano, São Paulo. Sala de Curativo - emergência. Fonte: Grunow, 2002.

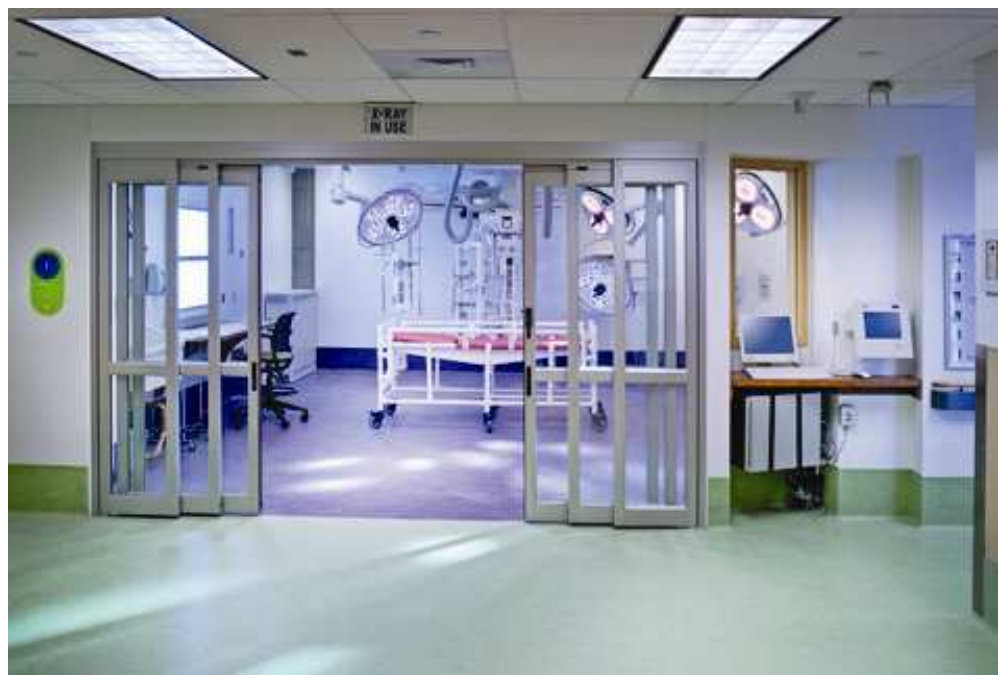

Figura 80 - Children's Hospital of Pittsburgh of UPMC. Sala de centro cirúrgico. Fonte: www.chp.edu/CHP/Home.

Nas figuras acima, as composições cromáticas são determinadas pelas cores frias, de baixa saturação e média luminosidade, que interagem com a iluminação artificial. A composição também apresenta detalhes com cores quentes ou mais luminosas (Figura 79 e 80). 
Como nos exemplos ilustrados, as indicações, quanto ao uso de cores frias, são que sejam utilizadas em ambientes pequenos. Também é recomendado, esse tipo de composição, em ambientes que tenham superfícies com texturas destacadas e possuam alto nível de ruído no ambiente próximo. Caivano (2004) salienta que esse esquema de composição deve ser usado em ambientes de longa permanência, destaca ainda, que se podem obter melhores resultados se, a composição de cores frias, for aplicada em ambientes com iluminação fluorescente quente ou incandescente.

\subsubsection{Cores Quentes}

Deve-se evitar o uso de cores quentes em ambientes que lidam com pacientes depressivos, segundo Malkin (apud TOFLE et al., 2004) e César (2003). Para Caivano (2004), o uso de cores quentes é indicada para ambientes que, não tenha, atividades que necessite de esforço físico, sejam grandes, e que possuam baixo nível de ruído no ambiente próximo. Também está relacionado o uso de cores quentes em ambientes que tenham superfícies com texturas moderadas. A composição fundamentada em cores quentes deve ser usada para locais de curta permanência de tempo e, que, preferencialmente, tenham iluminação artificial de lâmpada fluorescente fria, para equilibrar os seus efeitos perceptivos, não sobrecarregando a percepção visual.

\subsubsection{Cores Saturadas}

As cores saturadas podem compor esquemas para ambientes de curta permanência, criando uma atmosfera de vivacidade, e que apresentem baixo nível de ruído próximo, pois, conforme os estudos apontam, as cores saturadas possuem uma característica perceptiva de aumentar a sensação de ruído (CAIVANO, 2004).

Tofle et al. (2004) complementam mencionando que o uso de cores saturadas depende do tamanho da superfície, devendo essa ser levada em consideração, sendo o seu uso indicado para detalhes e pequenas superfícies. Costi (2002) sugere que o emprego de cores saturadas seja usado como uma forma de organização visual, em contrastes de detalhes. 


\subsubsection{Cores Brilhantes}

As cores brilhantes, no ambiente hospitalar, devem ser usadas com cautela, devido a sua reflexão luminosa; por si só, o ambiente hospitalar apresenta materiais e equipamentos que já emitem muito brilho, além das características gerais de iluminação, que aumentam ainda mais tal característica. Em muitos autores é possível ver indicações do uso de cores brilhantes em superfícies menores, secundárias, na composição total, tais como batentes e acentos (Figura 82).

Outra característica das cores saturadas com alto brilho, é que proporcionam um aumento na percepção de ruído do ambiente, sendo indesejável no ambiente hospitalar. O ruído é um dos pontos, apontados por Ulrich (2000b), Malkin (2008), Barach e Dickerman (2006) e Nelson, West e Goodman (2005), como um dos principais fatores da causa do stress hospitalar. Portanto, seu uso deve ser explorado cautelosamente e com ponderação.

A figura baixo (Figura 81) apresenta um esquema cromático com ampla variedade de matizes, saturação e luminosidade. A iluminação, no ambiente, é composta por clarabóia e complementada com iluminação direcionada para alguns pontos de destaque, a iluminação não prejudica a composição cromática que já apresenta alta refletância e contraste intenso pelo uso de cores brilhantes. As cores quentes predominam no ambiente e se destacam das cores frias; localizadas ao fundo.

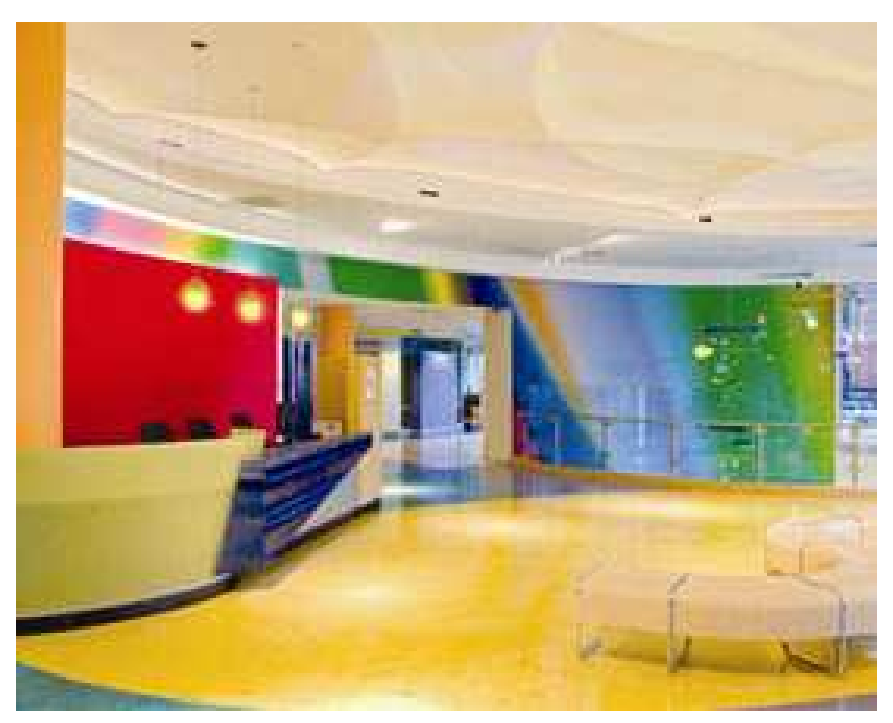

Figura 81 - PSE\&G Children's Specialized Hospital, Nova York. Recepção. Fonte: www.hksinc.com/healthcare.

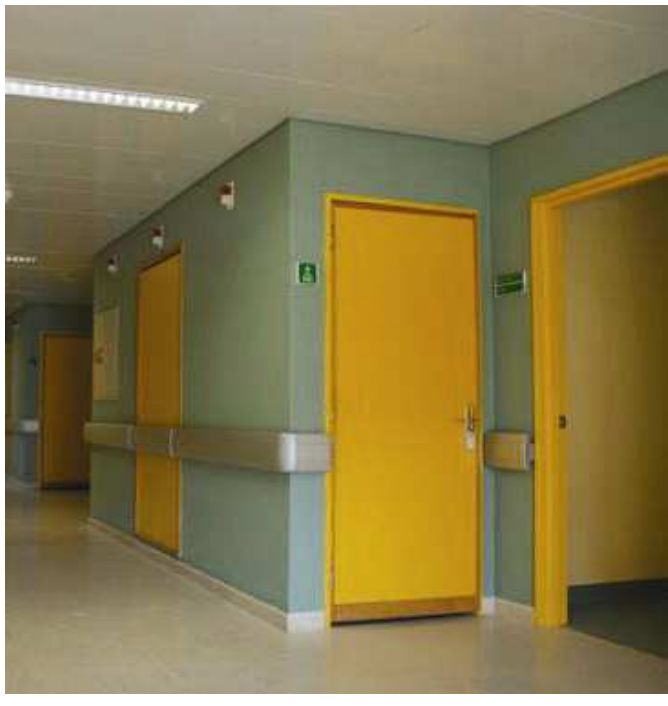

Figura 82 - Hospital de Santo André, Portugal. Ala de internação. Fonte: www.sites/joaopernao/hospitaldesantoandre. 
Outra característica das cores brilhantes, segundo Tofle et al. (2004, p. 60), é que se atribui aos graus de brilho e escuridão a percepção de amplitude, influenciada contundentemente, pelos efeitos de contraste; "[...] particularmente os contrastes de distinção de brilho, na relação figura-fundo [...]". Uma indicação constante, na literatura sobre o tema, é o uso de cores brilhantes e saturadas para locais onde se tenha pacientes idosos, que conforme já visto, possuem uma carência de acuidade visual e reagem melhor a cores com essas características.

Na composição abaixo (Figura 83) há a presença de cores saturadas e brilhantes delineando elementos compositivos e pontos de interesse, que estão aplicadas em detalhes. A composição cromática ainda integra cores quentes e frias, balanceadas pela extensão das superfícies aplicadas; as cores mais suaves servem de fundo e apoio para as demais se sobressaírem.

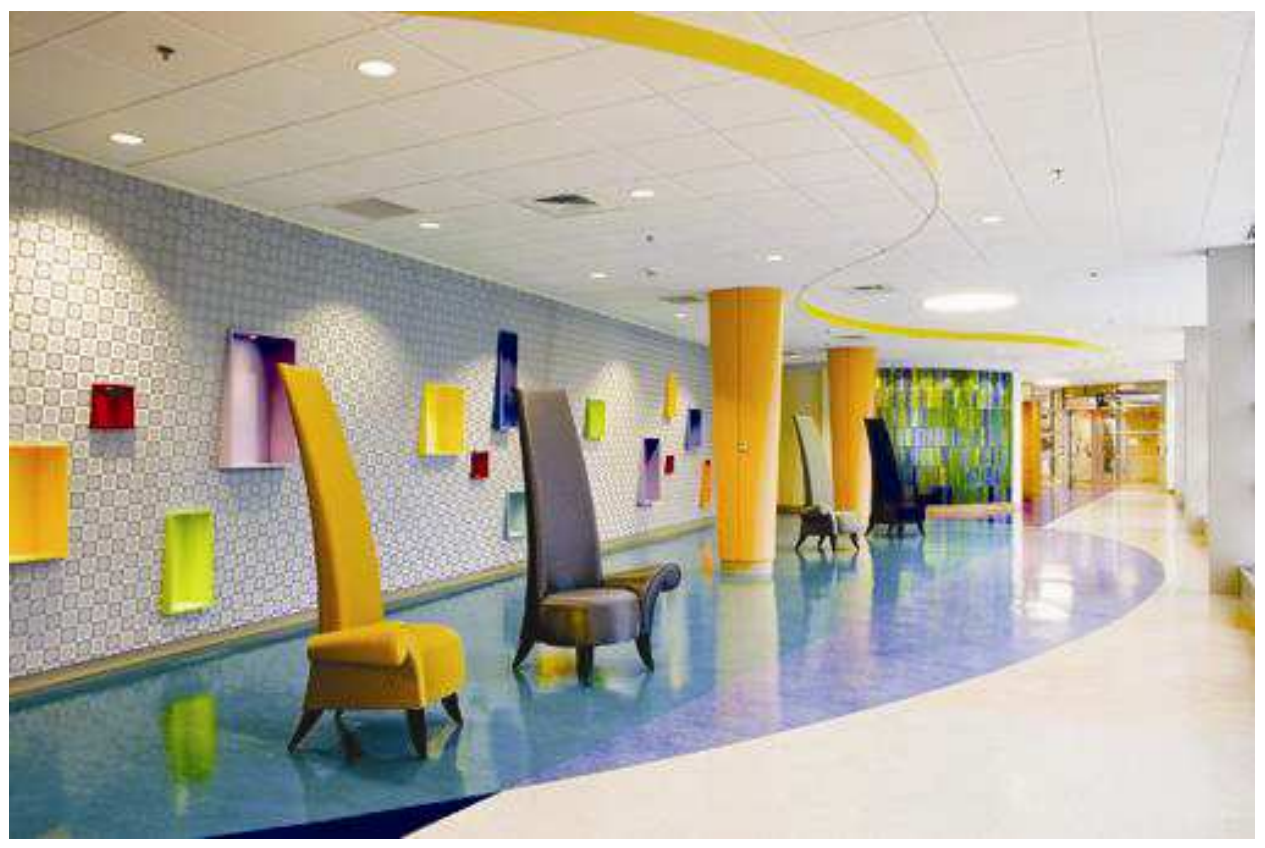

Figura 83 - PSE\& G Children's Specialized Hospital, Nova York. Fonte: www.hksinc.com/healthcare.

As exposições apresentadas são indicações que ao longo de várias pesquisas, e principalmente, experiências espaciais, puderam ser identificadas. Não representam de forma alguma, uma composição de paleta cromática ideal, com diretrizes universais para a aplicação das cores em ambientes hospitalares, pois esse tipo de proposta é como citam Tofle et al. (2004, p. 69), ineficaz.

Foi debatido o papel das interpretações, tradições e das experiências que o observador confere ao ambiente percebido, mudando de pessoa para pessoa, 0 
significado daquele. A pluralidade, presença de múltiplos grupos sociais, faixas etária, além da diversificação de referências culturais, traz consigo a complexidade dos assuntos sobre a significação, nesse sentido, qualquer esforço para prescrever diretrizes cromáticas universais, é um empreendimento improdutivo.

A paleta cromática para um edifício hospitalar conta com inúmeros artifícios e condicionantes, além de os objetivos pré-determinados. O contexto, os materiais e a localidade terão uma grande influência sobre como o ambiente será projetado e, posteriormente, vivenciado.

As indicações apresentadas podem gerar composições as mais variadas possíveis, como Arnheim (1988) acentua ao afirmar que a identidade da cor, que não reside na cor em si, é estabelecida por relação, sendo inúmeras as possibilidades de cores, e suas relações. No entanto, algumas considerações representativas como afirma Kadar (2007), podem ser pontuadas. Dessas experiências, conclui-se que mais que o matiz usado, o fator importante no aspecto da percepção, é o brilho, pois esse pode contribuir para o conforto visual, ou não, causando prejuízos para os desempenhos das atividades desenvolvidas ou o bem-estar dos pacientes.

O que, claramente, fica evidente é que o ambiente monocromático ou acromático, como o uso predominante do matiz branco que foi por muito tempo utilizado no hospital, possui algumas características palpáveis, como o de produzir ambientes neutros, e como afirmam Dalke, Littlefair e Loe (2004): "[...] ambientes neutros produzem qualquer coisa, mas, efeitos neutros [...]", e efeitos neutros não são, como demonstrado, os mais adequados para um ambiente hospitalar.

Assim sendo, as cores e o uso de contrastes podem ser ferramentas produtivas para os ambientes hospitalares. O equilíbrio, que depende da informação visual produzida pelo ambiente, pode ser alcançado quando se considera o espaço em sua totalidade, as cores das paredes dominantes, subdominantes (teto, piso, elementos de decoração), e contrastes de cor, como menciona Dondis (1997, p. 113): "[...] seja qual for a linguagem empregada para expressar as duas polaridades da comunicação visual (aguçamento ou nivelamento / contraste ou harmonia), deve-se enfatizar que ambas constituem excelentes instrumentos para elaborar uma manifestação visual com clareza de ponto de vista". 


\subsection{APLICAÇÃO DA PALETA CROMÁTICA NO DESIGN HOSPITALAR}

\subsubsection{Elementos Arquitetônicos}

Tornar um hospital mais humanizado envolve diversos métodos, fatores e disciplinas. Ao papel que cabe à cor é vasto, e pode ir muito além das tintas nas paredes e nos desenhos dos pisos. Abaixo serão apresentados os elementos da arquitetura em que a cor pode ser aplicada, constituindo composições cromáticas; salientando que o aspecto final, ou seja, a percepção espacial e cromática de um ambiente é constituída por todos os elementos presentes, incluindo, até mesmo, uma obra de arte.

\subsubsection{Piso}

A escolha do material faz toda a diferença para a composição cromática, pois suas características físicas resultaram em um ou em outro resultado cromático. A escolha, de maneira geral, deve ser embasada em questões principais como assepsia, facilidade de locomoção e manutenção, segurança e aspectos estéticos. É possível encontrar materiais bem diversificados, como carpetes, mármores, e pisos de borracha, ou ainda, para circulações pesadas, o vinil, PVC e linóleo.

Os pisos de vinil possuem certa vantagem, pois a relação custo-benefício é bem compensadora, além de possuir, positivamente, as principais qualidades exigidas. No entanto, esse material apresenta uma característica visual de intenso brilho; os pisos de vinil mais antigos refletem, geralmente, muito a iluminação, causando clarões e ofuscamento aos usuários, já os novos são produzidos com material que não produzem tais incômodos. Os padrões existentes desse material são inúmeros, mas, as recomendações dos designers do ambiente hospitalar (MALKIN, 2008; DALKE; LITTLEFAIR; LOE, 2004) são que se utilizem padrões mais simples, uniformes e com cores mais neutras, e não muito escuras, apesar dos pisos escuros gerarem maior sensação de segurança, estabilidade e equilíbrio. Já os padrões geométricos ou assimétricos podem causar sensação de instabilidade além de confusão e poluição visual. 
O carpete tem sido uma opção para áreas de atendimentos, tais como recepção e lobby, ou áreas não relacionadas aos cuidados de saúde; mesmo tendo inúmeras pesquisas que mostraram que o carpete possibilita melhor locomoção dos pacientes idosos, dando maior sentimento de segurança e equilíbrio (ULRICH, 2000b), ele não é um material muito utilizado. Segundo Dalke, Littlefair e Loe (2004), o carpete dificulta a manutenção, prejudicando a assepsia e as questões de higiene; requisitos básicos para os materiais a serem utilizados no ambiente hospitalar.

A escolha das cores de um piso deve seguir algumas diretrizes, as principais apontadas por Malkin (2008), Mahnke e Mahnke (1996) e Dalke, Littlefair e Loe (2004) são: utilização de cores que não esconda a sujeira, nem que apareça demais; deve proporcionar aparência de segurança e estabilidade; para a cor escolhida deve ser levada em consideração a questão do ofuscamento, como cores luminosas, ou com alto índice de reflexão, que causarão desconforto aos usuários.

\subsubsection{Paredes}

Nas paredes, pode-se haver uma grande variedade cromática, compondo com as características do piso e dos elementos decorativos. Dalke, Littlefair e Loe (2004) sugerem que em espaços de grande tráfego se use uma maior variedade de cores, criando um visual interessante. O uso de cores luminosas, nas paredes, é uma forma de ajudar e de compensar qualquer falta de luz natural, ou deficiência, na iluminação artificial, aumentando os níveis de iluminação ambiente.

As paredes recebem especial atenção quanto ao uso das cores, pois, como visto nos estudos de Billger e Anter (2000, 2004, 2006), elas são responsáveis pela maior parte da luminância em um ambiente, tendo, nas reflexões de suas cores, grande potencial de percepção e influência no aspecto final. As paredes possuem aberturas, portas e janelas, e essas desempenham um papel importante, como elementos de influência nas percepções cromáticas.

As janelas ocupam grande parte do campo visual, influenciando a visão do ambiente e tendo impacto na iluminação ambiental, conforme o design do ambiente que inclui iluminação artificial, posicionamento da janela, orientação e composição cromática 
das paredes, principalmente aquelas que encerram a janela e aquela que se encontram de frente à janela.

No caso das paredes que recebem a luz proveniente das janelas, a indicação é que as cores não sejam tão escuras ou saturadas, para não roubar a luz, diminuindo a iluminação no ambiente, por outro lado, tão pouco é desejável que se utilize cores muito claras ou brilhantes, para que não reflitam demasiadamente a luz natural, causando ofuscamento ou excesso de reflexos. Já as paredes, que enquadram as janelas, não devem ter cores muito escuras, que, ao se olhar para elas, cause grande contraste de iluminação, de claro-escuro, prejudicando a visão e a adaptação da retina.

Nas paredes, as cores podem ser empregadas para compor a orientação e/ou o zoneamento, e também podem servir como pano de fundo para elementos arquitetônicos (Figura 85) ou decorativos (Figura 84). Nas áreas destinadas à pediatria e seus ambientes de apoio usa-se, atualmente, elementos decorativos compondo o visual, cromaticamente, proporcionando ao ambiente hospitalar uma atmosfera alegre, descontraída e lúdica, é um recurso muito valorizado. Na figura 84 pode-se notar exemplo desse tipo de aplicação. Os desenhos interagem com a composição cromática dos outros elementos, criando destaque e estímulos visuais.

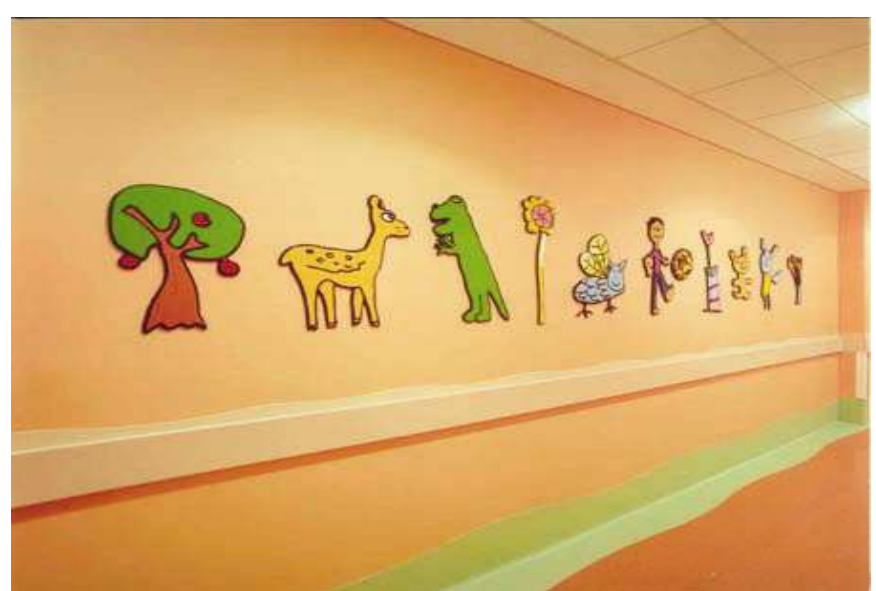

Figura 84 - Bristol Royal Hospital of Children, Reino Unido. Fonte: www.publicartonline.org.uk/casestudies/health/brch/images.php.

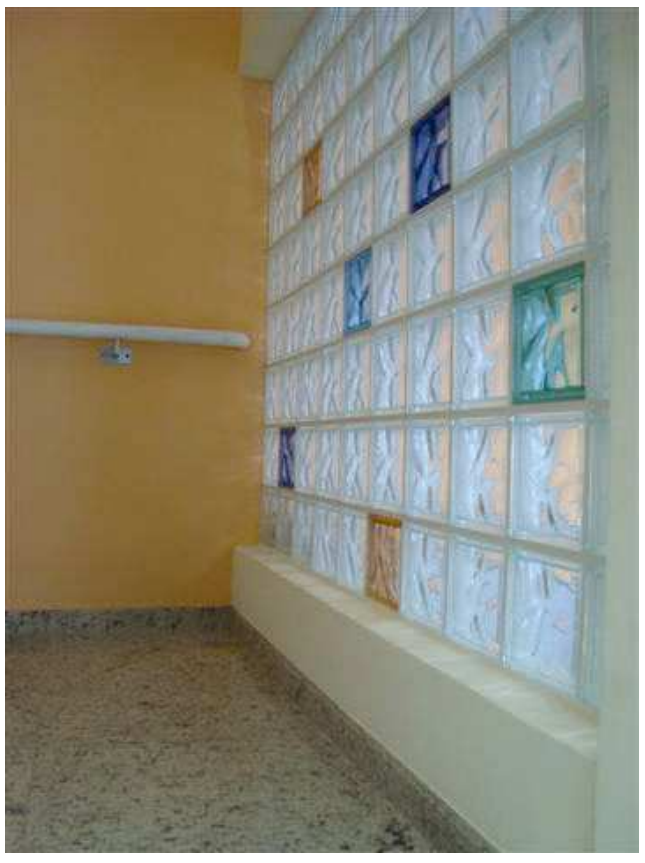

Figura 85 - Hospital Regional do Vale do Paraíba. Uso das cores em elementos da arquitetura. Fonte: Anne Matarazzo. 


\subsubsection{Teto}

Quanto à aplicação das cores, no teto, é frequentemente utilizada a cor branca. Segundo alguns autores, o branco ajuda nos níveis de iluminação, não prejudicando o atendimento, a produtividade e o diagnóstico dos pacientes. Entretanto, nem sempre o ideal é se ter tetos brancos, a cor branca reflete iluminação, podendo criar um ambiente desconfortável, levando-se em conta que a visão, em primeiro plano de um acamado, é o teto.

Utilizar matizes suaves é uma opção para reduzir o clarão e promover uma visão confortável, outra composição supõe introduzir elementos decorativos ou funcionais a ele, como é o caso da colocação de televisores com imagens da natureza, atualmente um recurso muito utilizado em salas de exames e tratamentos.

Em casos de ambientes com pé-direito muito alto, o uso de cores saturadas e escuras pode ser uma opção para equilibrar a sensação de altura (Figura 86) e ainda criar um design inusitado, com pontos de interesse, e que interage com os demais aspectos cromáticos do ambiente. Já em alturas baixas ou corredores muito extensos, utilizar cores saturadas ou padrões muito chamativos pode transmitir sentimento de claustrofobia e peso.

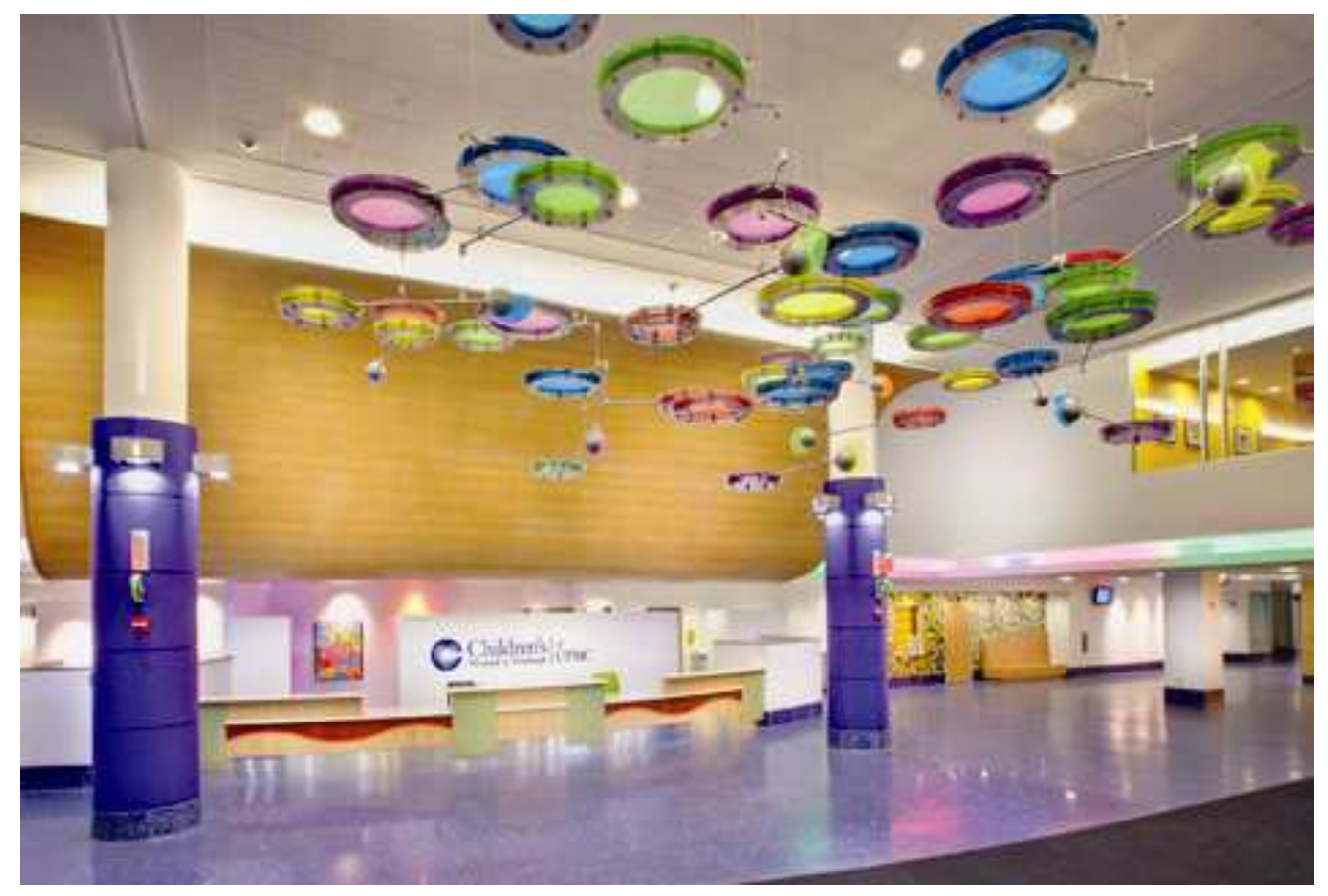

Figura 86 - Children's Hospital of Pittsburgh of UPMC.

Lobby principal.

Fonte: www.chp.edu/CHP/Home. 


\subsubsection{Elementos Decorativos}

\subsubsection{Tapeçaria e Mobiliário}

São elementos de grande importância, pois representam considerado aspecto do campo visual, tanto, nos quartos dos pacientes, como, nas salas de espera, recepções e posto de enfermagem. O mobiliário, tanto o de apoio ao serviço como o decorativo, afetam a composição final. Como são elementos soltos, no ambiente, ou em menor escala, podem ser usados em cores mais fortes, saturadas ou com padrões mais rebuscados, assimétricos e maiores; esses detalhes serão significativos para a composição cromática final.

A escolha das cores a serem usadas na tapeçaria deve ser baseada em critérios práticos e estéticos. A mobília acrescenta a impressão global de um ambiente e, normalmente, é uma parte grande e bastante permanente do ambiente construído. A questão da qualidade pode ajudar os pacientes a se sentirem mais confortáveis e à vontade (DALKE; LITTLEFAIR; LOE, 2004). Também deve ser levada em consideração a questão da durabilidade dos materiais e tecidos.

Segundo César (2003), a tapeçaria e os mobiliários complementam a composição cromática de um ambiente, devendo esses dar o "[...] particular caráter de vivacidade e graça [...]"; aspectos tão salientados, nos textos de Malkin (2008), Dalke, Littlefair e Loe (2004) e Ulrich (2000b). Tais detalhes tornam a arquitetura hospitalar mais privativa, gerando senso de acolhimento e proteção (Figura 87).

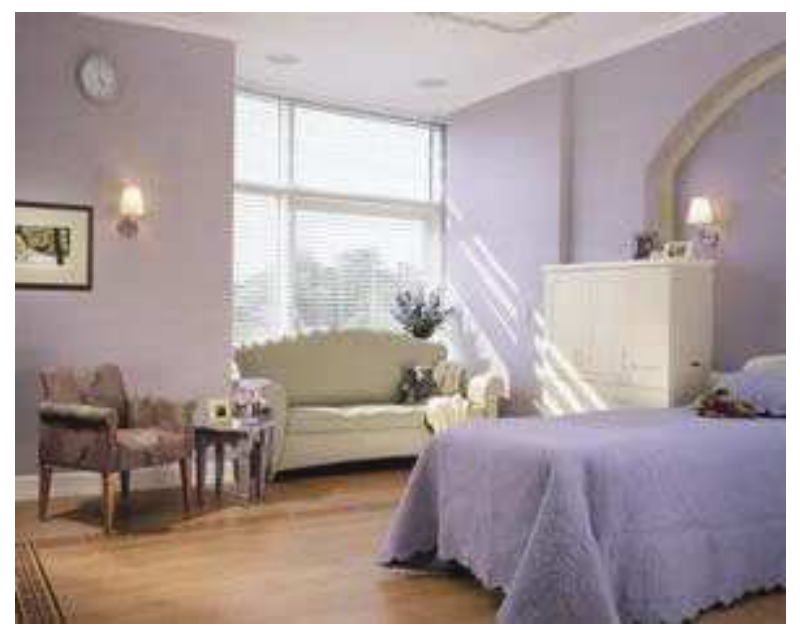

Figura 87 - Boulder Community Hospital, Colorado. Fonte: Oz Architecture. 
Na figura acima o design do mobiliário e da tapeçaria criam um ar aconchegante e intimista, as cores utilizadas reforçam o aspecto personalizado do quarto do paciente, a composição cromática final proporciona harmonia e, destaca o tema mencionado acima, proporcionar ao ambiente impessoal do hospital um grau de particularidade.

Com relação ao aspecto levantado por César (2003), que encerra em si sensações como o senso de acolhimento, e fazendo um paralelo com Tuan (1983, p. 6), que incorpora à noção de lugar, valores como, definição e significado, conforme cita: "[...] espaço é mais abstrato do que lugar [...] o que começa como espaço indiferenciado transforma-se em lugar à medida que o conhecemos melhor e o dotamos de valor", nota-se uma questão importante para o processo de recuperação da saúde do paciente. Remete ao tema da compreensão dos significados e simbologias incorporados ao ambiente hospitalar, à apropriação do espaço, e identificação dos domínios do espaço hospitalar, "[...] o caráter público e privado permeia os diversos espaços, dando um sentido particular a cada um deles" (COSTA, 2001), aspectos tão importantes para o bem-estar psicológico do paciente, discutidos por Hall (1977), Dilani $(2000,2003)$ e Ulrich (2000b).

\subsubsection{Obras de arte}

Roger Ulrich (2000a, 2000b), em um de seus estudos, compara resultados de pacientes em recuperação de cirurgias cardíacas, expostos a diferentes tipos de imagens. Parte dos pacientes foi exposto a imagens da natureza, outros não receberam nenhum tipo de estímulo visual de imagens, e outros expostos a imagens abstratas. A pesquisa revelou que os pacientes expostos a imagens da natureza, contendo em seu teor elementos como, água e árvores, mostraram-se menos ansiosos e requereram menos doses de medicamentos para as dores, essas, menos fortes. Em outra pesquisa, também sobre os efeitos de imagens em pacientes, Ulrich (2000b) constatou a preferência dos pacientes por artes realistas, que representavam ambientes naturais às abstratas.

As obras de arte são apontadas por Malkin (2008) e Dalke, Littlefair e Loe (2004) como artifícios para se obter variedade cromática. Elas podem trazer para os ambientes monocromáticos, ou sem grandes contrastes e variedades, cores de 
diferentes intensidades, despertando estímulos visuais e distrativos para os pacientes, visitantes e outros usuários, em consonância com os objetivos pleiteados para a humanização do ambiente hospitalar. Na figura 88, painéis utilizados em diversos pontos do Herlev Hospital, na Dinamarca; os painéis desempenham diversas funções, entre as quais a de zoneamento e demarcação de circulações.

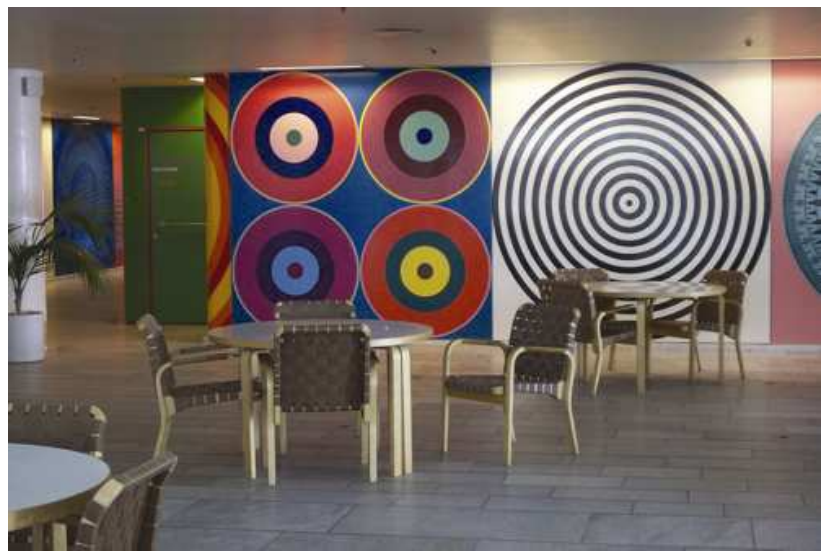

Figura 88 - Herlev Hospital, Dinamarca. Fonte: Dalke; Matheson, 2007.

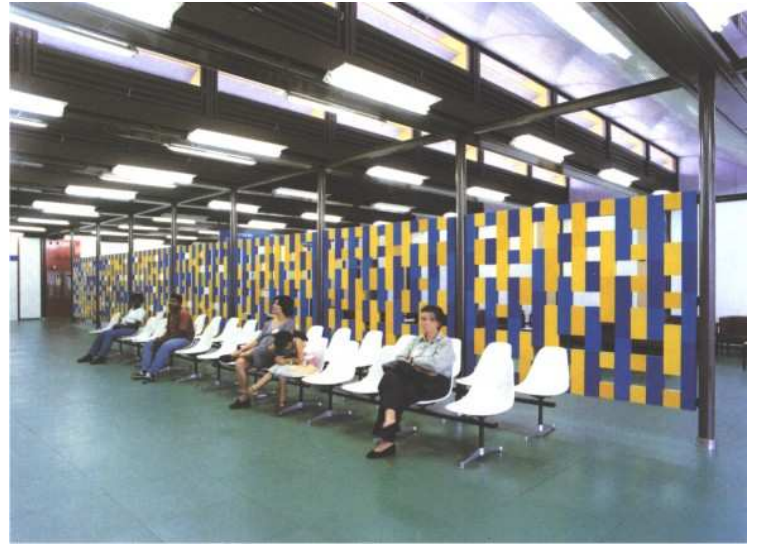

Figura 89 - Elementos artísticos. Athos Bulcão. Hospital da Rede SARAH. Fonte: Latorraca, 2000.

Um exemplar brasileiro de ambiente hospitalar que usa de elementos artísticos para compor o espaço, é a Rede de Hospitais Sarah Kubistchek, projetados pelo arquiteto, João Filgueiras Lima - Lelé. A arte está aplicada em painéis de autoria do artista plástico, Athos Bulcão (Figura 89), incorporada à arquitetura como elemento não apenas decorativo, mas também funcional e estético.

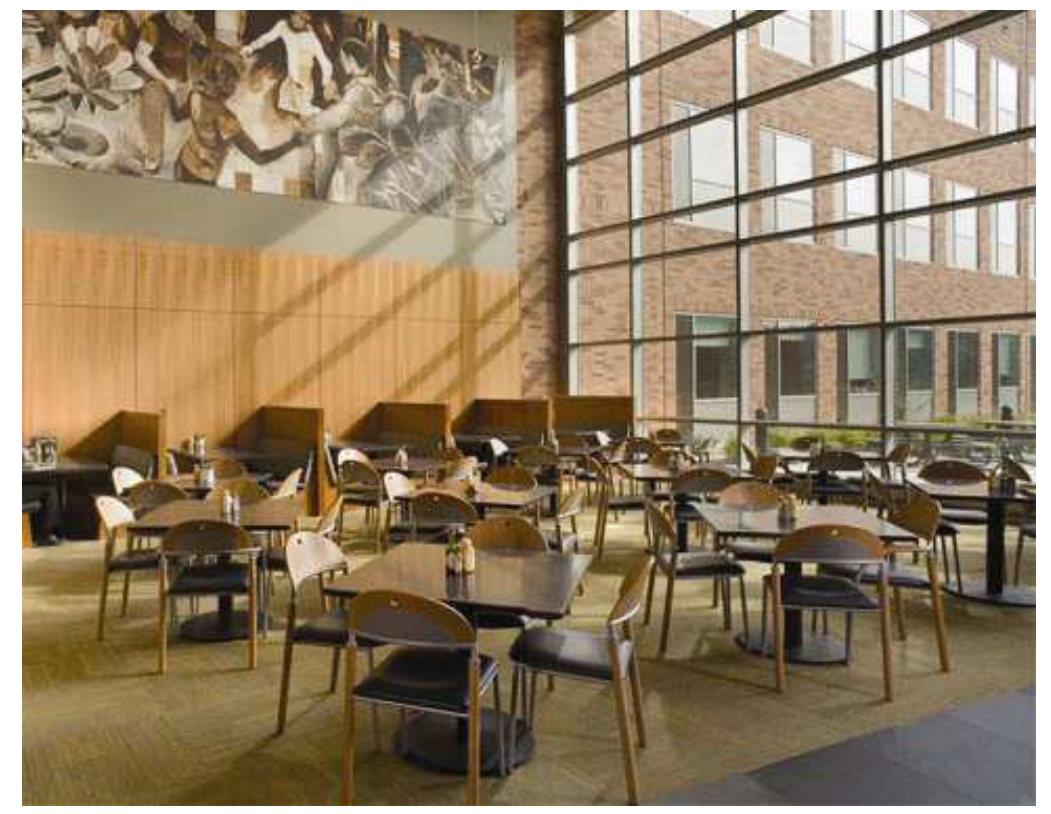

Figura 90 - Providence Newberg Medical Center. Fonte: www.mahlum.com. 
O área do café e lanchonete proposto, pelo escritório de arquitetura Mahlum, para o hospital Providence Newberg Medical Cente, em Oregon (Figura 90) integra o ambiente de tal maneira que cria uma identidade visual cromática nítida e harmônica. A composição cromática está integrada aos diversos elementos do ambiente, no mobiliário e tapeçaria, nas texturas, nos jogos de luzes e sombras e na obra de arte, que acentua a identidade cromática do ambiente.

Como se pode notar, os elementos da arquitetura, capazes de se aplicar as cores são amplos. A composição cromática aparece em diversos meios, de materiais à superfícies, não se prevendo uma paleta cromática somente para paredes, teto e piso; a sua aplicação, no ambiente hospitalar, vai muito além. Mobiliários, quadros, e até mesmo os equipamentos são irradiadores das cores, que, por fim, irão compor o aspecto e aparência final de um ambiente.

Como Malkin (2008) e Guzowski (1999) salientam, o planejamento de um esquema cromático, consiste em reconhecer todos esses elementos; detalhes estéticos da arquitetura no ambiente. A cor, que fará parte da paleta cromática para uma composição, pode ser a do próprio material, como um granito, um mármore, uma madeira ou, pode ser de pigmentos e revestimentos; não importa de onde elas provêm, o resultado final, sua harmonia, conforto visual e qualidade devem ser o objetivo, afastando a monotonia e pobreza de estímulos visuais, criando ambientes estimuladores, capazes de motivarem as pessoas e auxiliam os pacientes em seu processo terapêutico. 
CAPÍTULO 8 O "HOSPITAL DO FUTURO":

BASES NAS COMPOSIÇÕES CROMÁTICAS 


\section{CAPÍTULO 8 \\ O "HOSPITAL DO FUTURO": BASES NAS COMPOSIÇÕES CROMÁTICAS}

\subsection{O "HOSPITAL DO FUTURO"}

Atualmente, os hospitais passam por uma nova fase de conceituação, que influi diretamente em seu projeto arquitetônico; não são transformações tão focadas e relacionadas aos seus aspectos físico-funcionais, mas, em suas particularidades, nos detalhes, na ambientação, nos aspectos de conforto ambiental e na sustentabilidade. Possuindo como objetivo principal conferir aos pacientes um ambiente propício para a sua cura; os projetos se apoiam em inúmeros estudos, que mostraram que o ambiente construído pode auxiliar de forma positiva ou negativa a sensação de bem-estar e o tratamento terapêutico dos pacientes.

O "Hospital do Futuro" não possui uma missão somente de cura ou, de tratamento da doença, ele desempenha uma função mais ampla. Dedica-se à formação continuada, como centro de ensino; desenvolve ação múltipla junto à sociedade, como instrumento de prevenção às doenças por meio de campanhas e atividades voltadas para a promoção à saúde e também possui uma vertente tecnológica e científica, como local de desenvolvimento de pesquisas focadas, na medicina, no paciente e até mesmo, na própria arquitetura.

Com os avanços tecnológicos cada dia mais modernos, a medicina, a biologia, a química, a física são disciplinas que se juntam para explicar as doenças, curas e descobrir tratamentos de saúde. As instituições hospitalares de simples prestadores de serviços médicos, hoje, concentram grande parte da produção de conhecimento com modernos centros de pesquisas e pesados investimentos em laboratórios.

O edifício hospitalar novamente volta ao centro da atenção, sendo debatida sua real importância para o processo terapêutico de cura e bem-estar do paciente; o arquiteto, por sua vez, é o articulador dessas inovações, sendo o mediador entre os agentes multidisciplinares que constituem a base do planejamento hospitalar. 
O foco do serviço hospitalar deixa de ser a doença, e passa a ser a promoção da saúde. Os administradores e colaboradores da instituição "hospital" voltam-se para o paciente, sendo esse o grande pivô das transformações do ambiente hospitalar.

Segundo Ulrich (2000b), a motivação para essas transformações são as evidências científicas que as características físicas do ambiente, de fato, influenciam nos resultados de saúde dos pacientes. Pesquisas mostraram que um ambiente bem projetado reduz a ansiedade e diminui a dor, entre outros fatores, paralelamente, outras pesquisas avaliaram a relação entre os ambientes com design "pobre" ou, que não tinham suporte psicossocial, com efeitos negativos, como aumento do tempo de internação, maior ocorrência de delírios e maior consumo de medicamentos, entre outros.

Ulrich menciona que a Johns Hopkins Medical School, sob a liderança de Haya Rubin, fez uma avaliação sobre o estado das pesquisas que relacionam o ambiente com a saúde. A investigação achou aproximadamente 100 publicações sobre o tema, que mesmo sendo uma quantia pequena de pesquisa para estabelecer padrões na área médica, muitas dessas são de qualidade, e podem justificar as evidências que os aspectos do ambiente construído ocasionam efeitos significativos nos resultados clínicos dos pacientes. Essas considerações encorajam mais estudos e, de certa forma, incentivam as discussões acerca do tema.

Nesse sentido, os projetos e serviços hospitalares, atualmente, estão sendo embasados por dois conceitos. O primeiro é o conceito evidence-based design (EBD), de acordo com a publicação Light [...] (2001), esse conceito pressupõe que o design seja elaborado baseado em evidências. O segundo conceito é baseado nas premissas de design, divulgadas pela Planetree, patient-centered care (cuidados focados no paciente). Dentre os princípios estabelecidos pela organização, estão o entendimento que a estrutura física é vital para o processo de cura e, portanto, deve ser desenhada para promovê-la e que o tratamento médico deve ter como suporte um ambiente confortável, ameno e acolhedor.

Os dois tipos de abordagens, acima mencionados, vêm se alastrando rapidamente nos Estados Unidos, e mais recentemente na Europa. Suas aplicações são 
especificamente voltadas para o desenvolvimento da arquitetura hospitalar, de forma a suportar as ações nos projetos de arquitetura.

Os hospitais que são considerados linha de frente do séc. XXI, e denominados de "Hospital do Futuro" por arquiteto, engenheiros, construtores e administradores, utilizam-se dos conceitos acima mencionados para a elaboração de seus ambientes.

Longe de ser futurista, o "Hospital do Futuro" é intimista. Procurar trazer ao ambiente impessoal hospitalar o aconchego do lar, a familiaridade para que o paciente se sinta seguro, a ponto de seu tratamento terapêutico ser beneficiado pelo ambiente e pelo bem-estar gerado a partir desse.

O edifício é projetado por um arquiteto com visão holística, no sentido de possuir amplo conhecimento de diversas áreas, que passa desde as ciências exatas às ciências humanas, com maior ênfase para as disciplinas da psicologia, neurociência e psicofísica. Da integração e das inter-relações dos conhecimentos dessas disciplinas, o arquiteto projeta um ambiente mais completo, no sentido de suprir todos os anseios dos pacientes e usuários, nas dimensões físicas e nas psicossociais. As relações sociais estabelecidas, no "hospital do futuro", vão além do domínio do quarto, ampliam-se para o exterior, com acesso a belos jardins e a outras distrações projetadas como suporte para elas.

Dilani (2000, p.31) nos fornece alguns dados:

A avaliação holística de ambientes de trabalho sob uma perspectiva multidisciplinar, considerando os fatores psicossociais, físicos e culturais como também os ergonômicos, têm estado desde muito longe limitada. [...] Com avaliações, ainda na fase inicial, podemos evitar consequências de um ambiente de trabalho inadequado [...] Processos de promoção à saúde estão se tornando cada vez mais fatores centrais na criação de instalações de cuidado médico. Neste novo paradigma, o foco está nos pacientes: as necessidades de sua saúde física e as necessidades da saúde psicológica e social [...] enfatizadas no design de ambientes hospitalares.

\subsection{EXPLOSÃO DE CORES PARA AS NOVAS DIRETRIZES PROJETUAIS}

Não ocasionalmente que as cores passam de coadjuvantes, como elementos decorativos, à protagonista do design arquitetônico hospitalar. Papel de protagonista, pois, às composições cromáticas, reserva-se um novo lugar, de 
destaque, como elemento capaz de inovar o ambiente hospitalar, para que as metas, acima ambicionadas, sejam alcançadas. Tal fato pode ser verificado em algumas produções arquitetônicas hospitalares recentes, na Europa e nos Estados Unidos; países que vêm investindo consideravelmente em pesquisas correlacionadas a esse tema.

Para a elaboração de um esquema cromático, no "hospital do futuro", o arquiteto estuda a fundo as características das cores, dos atributos de cor, da aparência de cor, as simbologias e associações, e mais recentemente, os estudos que cercam o conceito color emotional; uma abordagem recente do estudo das cores e que vem tentando orientar parâmetros que podem refletir em uma efetiva aplicação cromática na arquitetura. Desse modo, as composições cromáticas estruturadas em bases conceituais bem definidas evitam que as cores sejam escolhidas aleatoriamente ou guiadas por gostos pessoais.

O esquema cromático, geralmente, é desenvolvido com o apoio de um sistema de notação cromática como instrumento técnico, e neste sentido, o sistema de notação NCS vem se destacando, como uma ferramenta eficaz e direcionada para esse determinado fim.

\subsection{COMPOSIÇÕES CROMÁTICAS NO "HOSPITAL DO FUTURO": 3 CASOS}

Para ilustrar os conceitos, diretrizes e reflexões apresentadas, sobre o tema desta dissertação, serão apresentados três casos de hospitais projetados sob as diretrizes e métodos de projetação do "hospital do futuro", em que as cores são um dos principais elementos compositivos do espaço.

O método utilizado para a escolha desses hospitais consistiu, em parte, por uma análise do próprio projeto, como foi desenvolvido, em quais fundamentos estão apoiados, os métodos projetuais e os objetivos a serem alcançados com o design proposto. Para tanto, foi feito um levantamento de várias fontes, entre elas, a visão e argumentação projetual dos arquitetos envolvidos e averiguação dos objetivos, missão e valores procurados pelos administradores ou proprietários dos hospitais, devendo ter correlações com o tema estudado nesta dissertação. 
Mas também, em parte, a escolha foi motivada pela beleza e poesia que esses hospitais apresentam, pelo papel que o arquiteto desempenhou em todo o processo e pela relevância com o tema em questão. Esses podem ser considerados expressões do "hospital do futuro".

\subsubsection{Royal Hospital For Sick Children}

Para Kieren Morgan (apud YOUNG, 2010), diretor de desenvolvimento de saúde do hospital, os principais fatores que os levaram a escolher o projeto, para o novo hospital, foi a inovação, no design proposta pelo escritório de arquitetura Nightingale Associates, que usou conceitos como Sense Sensitive Design ou Sensory Design (design sensível).

Segundo, Malnar e Vodvarka (2004), projetar seguindo os conceitos do design sensorial significa o arquiteto saber como seus projetos impactam as pessoas. Esse conceito baseia-se, nos estudos de percepção, como os seres humanos percebem o espaço e a forma construída, baseados em diferentes teorias e pesquisas sobre os sensos humanos e as composições arquitetônicas. Alia percepção humana e projeto arquitetônico.

Dentre os principais estímulos de suporte para as necessidades de percepção, estão o som e a cor (SWAIN, 2010). Esses se diferem do contexto e são capazes de atrair o olhar, transmitindo informações relevantes, através do sensorial, apontam Malnar e Vodvarka (2004). Nesse sentido, a tomada de decisões de projeto é mais consciente e fundamentada, aliás tema amplamente discutido neste trabalho, que com a abrangência dessas questões, procurou mostrar novas direções futuras para a projetação do edifício hospitalar.

Young (2010) aponta que, de acordo com os propósitos, o projeto arquitetônico do Royal Hospital for Sick Children, em Edimburgo, Escócia, reflete os conceitos estabelecidos, promovendo uma arquitetura de altos valores de design. Percebe-se o importante papel do espaço arquitetônico, não de um abrigo para suprir necessidades de instalações físicas, mas de um elemento ativo no tratamento de cura. O projeto possui como principal característica da aplicação dos conceitos acima discutidos o uso de cores brilhantes e saturadas (NHSLOTION). 
Outra característica referente ao planejamento do hospital são os grupos de discussão envolvendo diversas áreas e formados por vários usuários do espaço hospitalar, como os futuros pacientes e seus familiares, corpo clínico e, entre outros, a Universidade de Edimburgo. Os grupos são divididos por temáticas, dentre as quais, estudos para o desenvolvimento do design.

Como pode ser conferido, nas figuras abaixo, as composições cromáticas desempenharam papel principal, no projeto do Royal Hospital for Sick Children, desde a concepção inicial, sendo utilizada como elemento de representação, como também, no design, como elemento da composição arquitetônica.

A composição cromática proposta por Nightingale Associates, segundo Swain (2010), inclui uma paleta de cores saturadas, brilhantes e um esquema de contrastes cromáticos valorizados pelas formas, ressaltando suas propriedades.
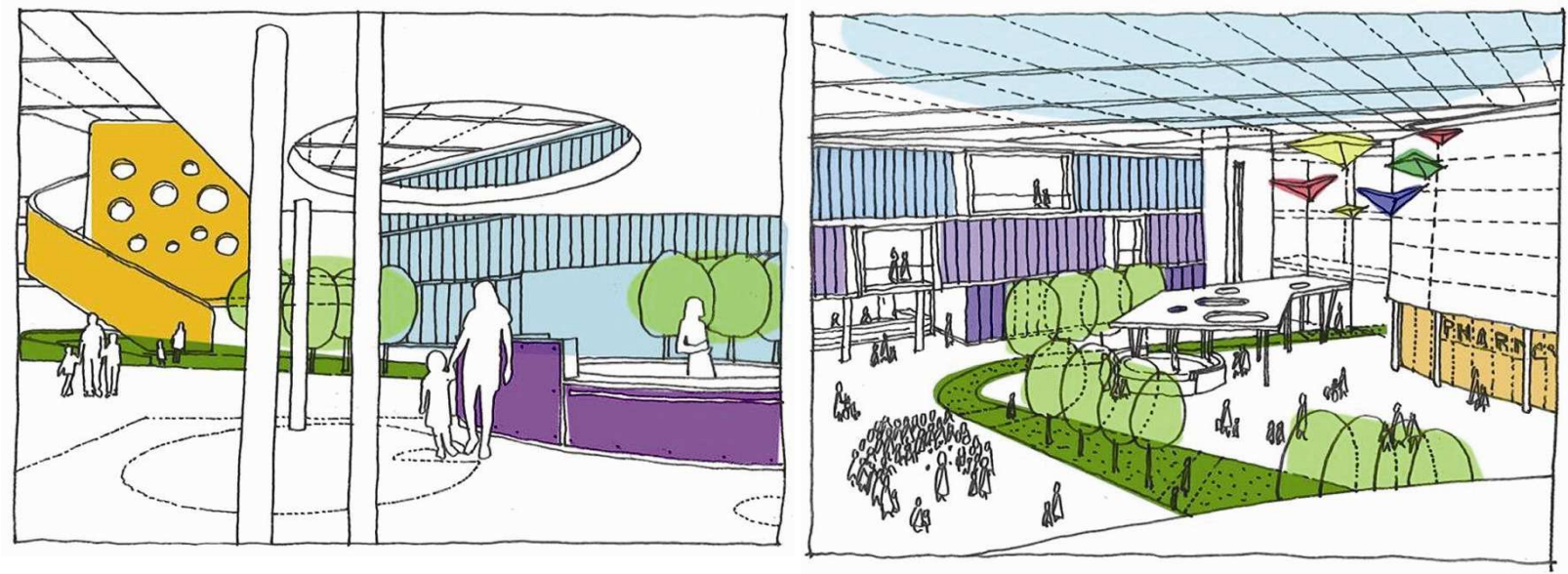

Figura 91 - Desenhos esquemáticos do átrio principal - Royal Hospital for Sick Children. Uso das cores já na fase inicial de concepção do espaço arquitetônico. Fonte: http://www.nhslothian.scot.nhs.uk/hospitals/rhsc.
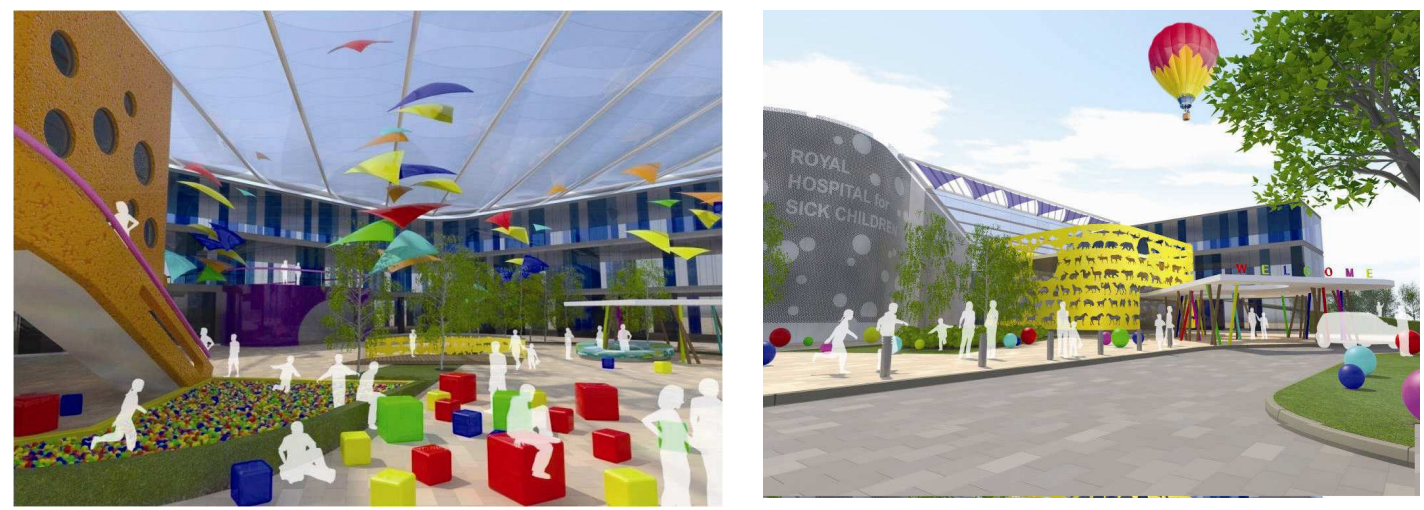

Figura 92 - À esquerda: Perspectiva do átrio. À direita: Perspectiva da fachada principal - Royal Hospital for Sick Children. Cores brilhantes se destacam e contrastam com as cores de baixa luminosidade e saturação da fachada.

No ambiente interno, composição cromática com cores primárias e saturadas nos detalhes decorativos compõe com a predominância de cores de baixa luminosidade e saturação, em uma relação de figura-fundo.

Fonte: http://www.nhslothian.scot.nhs.uk/hospitals/rhsc. 


\subsubsection{Karolinska Solna University Hospital}

É esperado, pelos construtores e administradores, que esse hospital seja o primeiro hospital universitário do mundo a receber a certificação LEED nível Gold e também o mais alto nível do Swedish Certification System Miljöklassad Byggnad (classificação de edifício ambiental da Suécia). Para tanto, o desenvolvimento do projeto, de responsabilidade do arquiteto Bengt Svensson, buscou unir conceitos como ambiente favorável à recuperação do paciente, uso de recursos naturais e acesso à natureza, sendo esses os pontos principais do design desse hospital.

O Karolinska Solna University Hospital está localizado em Estocolmo, Suécia. O objetivo principal da construção do novo hospital é, segundo o corpo administrativo do hospital, suprir a demanda médica e ser referência em pesquisas do futuro, ultrapassando sua função primeira de tratamento de saúde para centro de produção de conhecimento.

O projeto do novo hospital possui como missão número um, o lema "patient first" (o paciente primeiro), e o fator humano é o pivô central para todas as decisões projetuais, afirma a publicação Unique [...] (2010). Projetado sobre os holofotes da construção sustentável, alia as mais novas tecnologias com design inovador; com especial atenção para esse último item, que foi baseado em pesquisas que visavam promover a recuperação mais rápida do paciente.

O desenvolvimento do projeto arquitetônico envolveu uma competição internacional entre 17 escritórios de arquitetura, o escritório vencedor foi o White Architects, da Dinamarca. Segundo a administração do hospital, o projeto vem sendo desenvolvido desde 2005 e, para isso, foi feito um amplo estudo dos 50 melhores hospitais do mundo, aprendendo com os acertos e erros, para obter um projeto de alta qualidade.

Sob a orientação de seis metas, que constituem as fundações do design desse hospital, o projeto foi elaborado. Dentre as metas, duas se destacam pela proximidade com o tema desta dissertação. Uma é que cuidado médico, pesquisa e educação são integradas de forma a produzir conhecimentos novos para efetivamente ajudar no cuidado dos pacientes, e a outra, é que o projeto arquitetônico buscou criar ambientes atraentes, e que possuíssem altos valores arquitetônicos, dentro e fora ao hospital. 
Ambas as metas comportam o objetivo principal: de promover o tratamento do paciente o mais rápido possível, no melhor ambiente interno, segundo a publicação Unique [...] (2010, tradução nossa, grifo do autor):

Criatividade, inspiração e desenho brilhante combinados, para formar a imagem do arquiteto criativo, que nos causou maravilha e nos deixou pasmados. Mas quando a tarefa a alcançar é ser o melhor hospital, precisase de algo mais. Ter uma 'linha-guia' assegura, passo por passo, que a criação final viva idealmente até ultrapassar as visões originais.
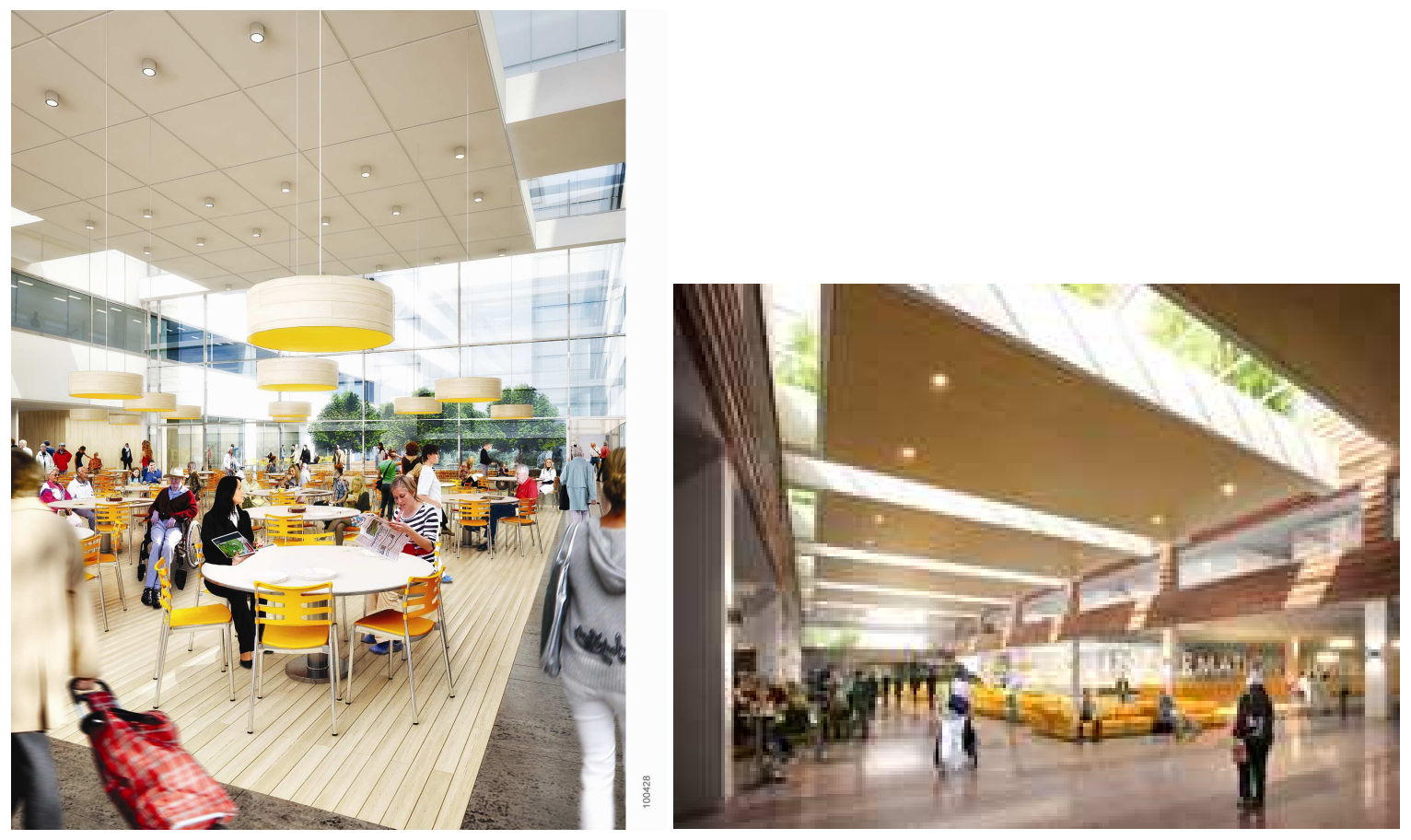

Figura 93 - Perspectivas das áreas internas - Karolinska Solna University Hospital.

Composição cromática baseada em contrastes de brilho, através do uso de cores brilhantes em detalhes. As cores estão presentes de uma forma diferenciada, pelo uso de diversidade de materiais e texturas que proporcionam variedade de estímulos compondo com um jogo de iluminação, natural e artificial. Fonte: www.white.se.

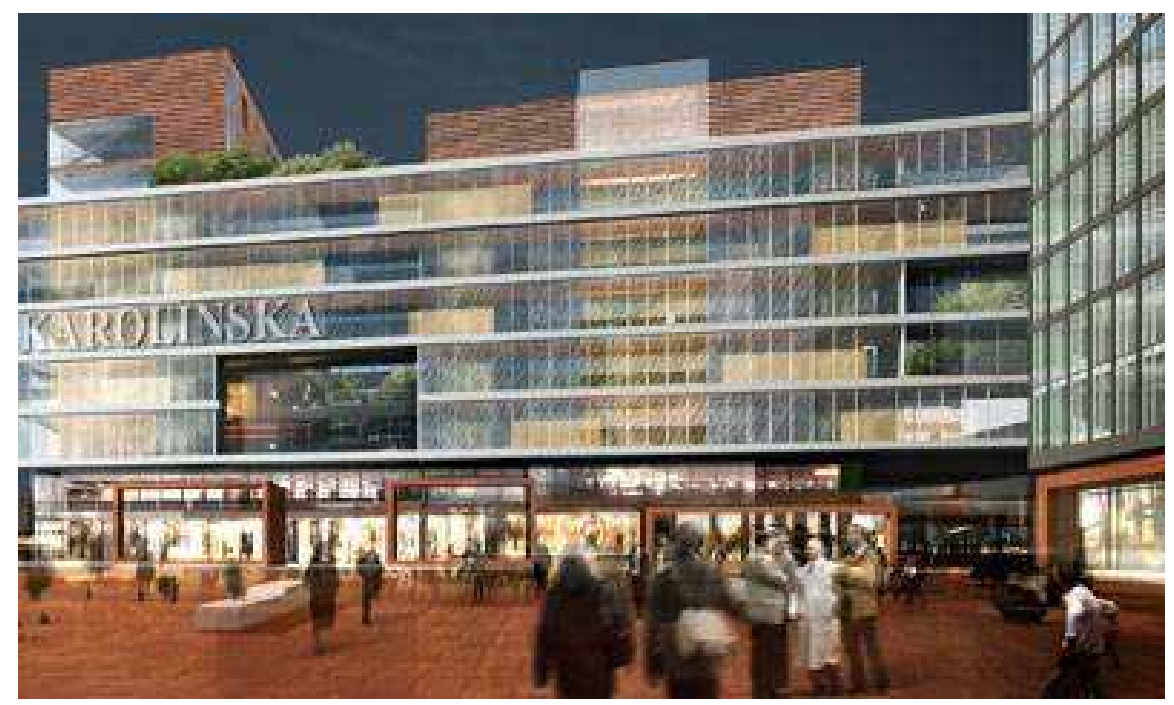

Figura 94 - Perspectiva da fachada principal - Karolinska Solna University Hospital. Fonte: www.white.se. 


\subsubsection{Children's Hospital of Pittsburgh of UPMC}

Astorino, arquiteto responsável pelo projeto, conta que para definir um partido ideal para o novo hospital, foi feita uma pesquisa com futuros usuários, familiares, administradores, corpo médico, entre outros; a pesquisa resultou em conclusões que orientaram a concepção do projeto, mas, sobretudo, o resultado da pesquisa mostrou que para o projeto do novo hospital, o arquiteto deveria olhar para o hospital como "aquele que nutre curando" (ASTORINO, 2010).

As cores, como elementos do espaço, destacaram-se, nas pesquisas, como um dos fatores mais importantes para os pacientes, que mostraram desejar o uso de cores mais elaboradas, ao invés dos tradicionais tons associados aos cuidados médicos; outros fatores relevantes para os pacientes apontados pela pesquisa foram energia e transformação (KAPKO, 2009).

Nesse sentido, a equipe do escritório de arquitetura Astorino, responsável pelo projeto arquitetônico, buscou usar inovações no design para implementar esses conceitos de um modo significante. Como elemento chave para tal tarefa, as composições cromáticas são as protagonistas da transformação do ambiente hospitalar, salienta Astorino. Por meio de inúmeros artifícios, elas conferem ao ambiente uma experiência única e mágica, vista sob a ótica da energia que elas emanam.

Para Astorino, a paleta cromática das composições é elaborada, e não desenvolvida ao acaso, sobre a escolha de cores vibrantes para o exterior do edifício, ele complementa:

\footnotetext{
Nós aprendemos com a pesquisa que, para estas crianças, a experiência do hospital começa no minuto que eles deixam as suas casas. Ao longe, quando veem 0 edifício e as suas cores, sentem uma energia positiva dando boas-vindas. É um lugar com 'o que eles podem ressonar emocionalmente'. (ASTORINO, 2010, tradução nossa, grifo do autor).
}

Como exemplo da elaborada composição cromática, pode-se citar o mural que acompanha um dos corredores principais do hospital, o longo mural possui uma ordem dinâmica de cores, essas representam as quatro estações (Figura 95). Nessa conotação, está o simbolismo, para as crianças, de mudanças e, que as famílias irão viver durante o processo curativo. 


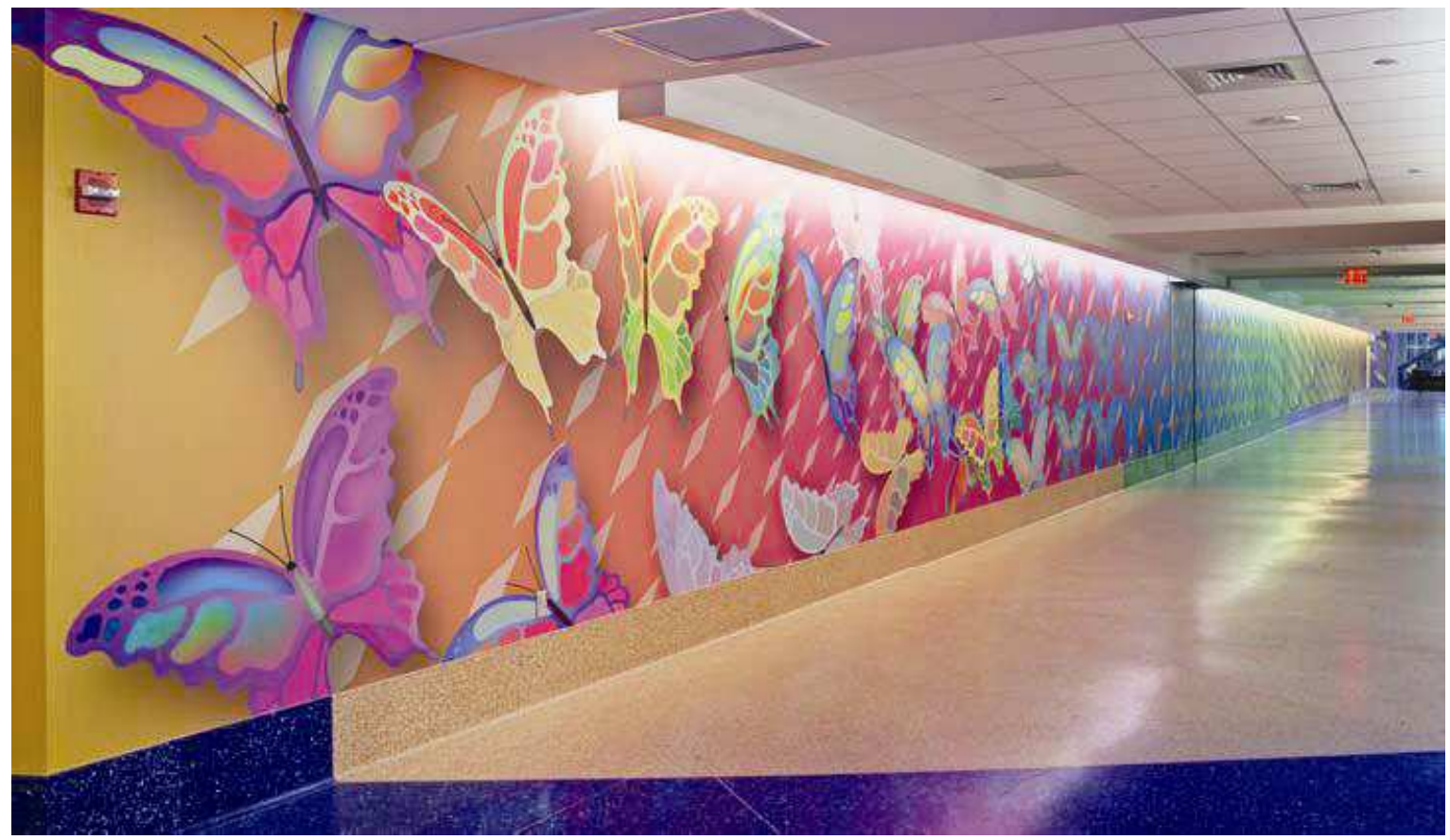

Figura 95 - Mural - Children's Hospital of Pittsburgh.

Variedade de matizes e uma composição de contrastes destacam-se no mural. Fonte: www.astorino.com/portfolio.

Assim, Eric D. Hess, vice-presidente e diretor executivo do CHP, ressalta: "[...] todos aspectos do hospital foram projetados para proporcionar um ambiente curativo [...]", com relação a esse assunto, Power (apud KAPKO, 2009, p. 14, tradução nossa), vice-presidente de cuidados médicos do escritório de Astorino, diz:

Nós acreditamos que a arquitetura tem a capacidade para ser um elemento no processo de cura. $\mathrm{O}$ ambiente não é secundário ao processo de cura. $\mathrm{Na}$ verdade, pode promover a cura se for elaborado efetivamente.

Segundo Astorino (apud KAPKO, 2009), todos os elementos do edifício foram projetados para nutrir essas relações, idealizadas pelos pacientes e administradores. Para isso, o design do Children's Hospital of Pittsburgh possui bases definidas e sólidas, apoiadas em fundamentos técnicos da psicologia, neurociência, antropologia e arquitetura. Esses fundamentos auxiliaram a propor metáforas e imagens visuais, ajudando a elaborar o projeto físico, criando uma mensagem marcante e global, e como salienta Kapko (2009), encaixaram-se nos anseios apontados pelos futuros usuários.

As metáforas que guiaram o design final tiveram como objetivo a criação do senso de ambiente familiar. "Em um nível fundamental, a experiência do hospital é sobre transformação de um desequilíbrio a um estado equilibrado" (ASTORINO, 2010, tradução nossa). 

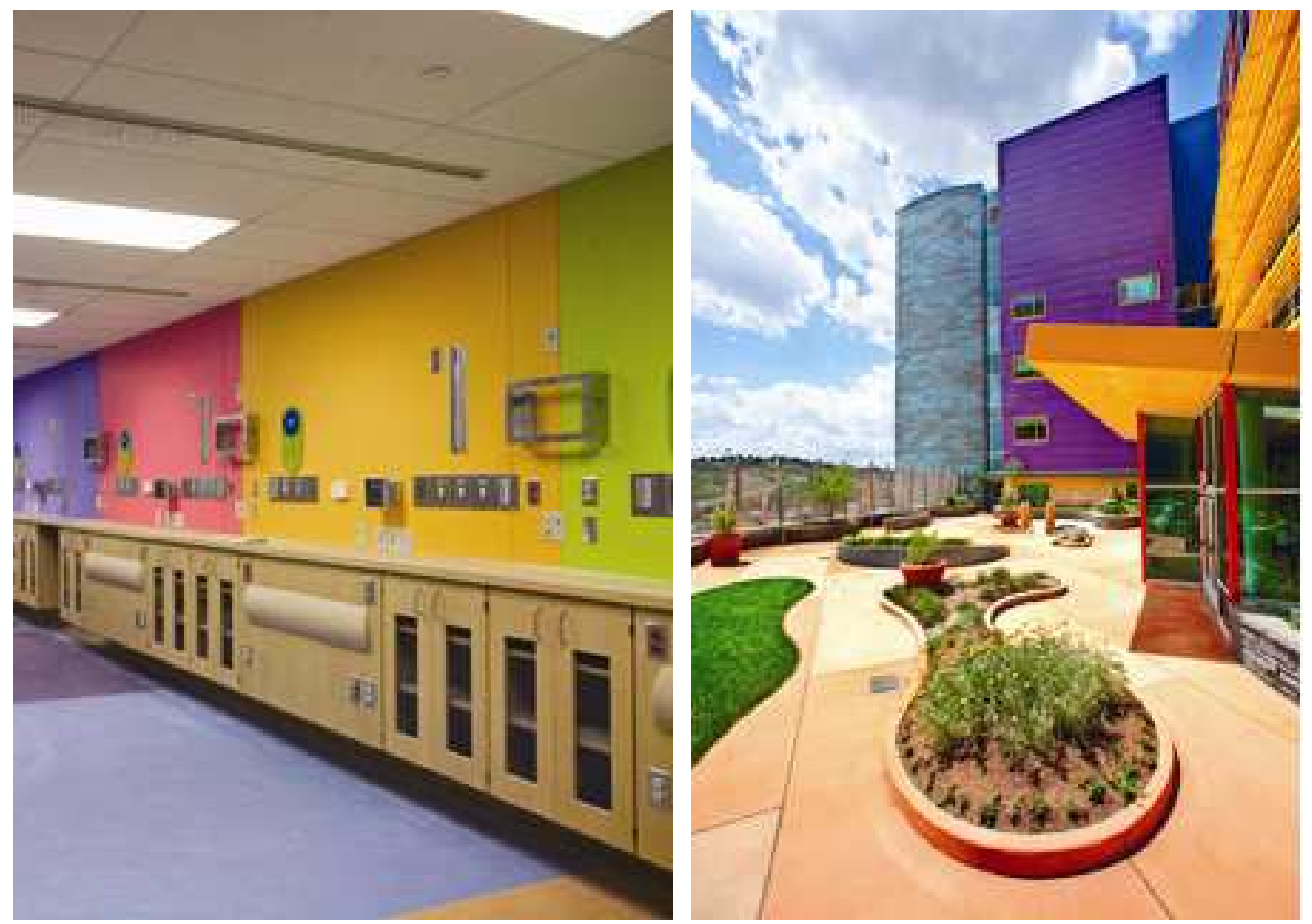

Figura 96 - À esquerda: Enfermaria. À direita: Jardim externo - Children's Hospital of Pittsburgh. Paleta cromática composta por variedade de matizes de média saturação, e uso de recursos como contrastes de luminosidade e brilho Fonte: www.astorino.com/portfolio.

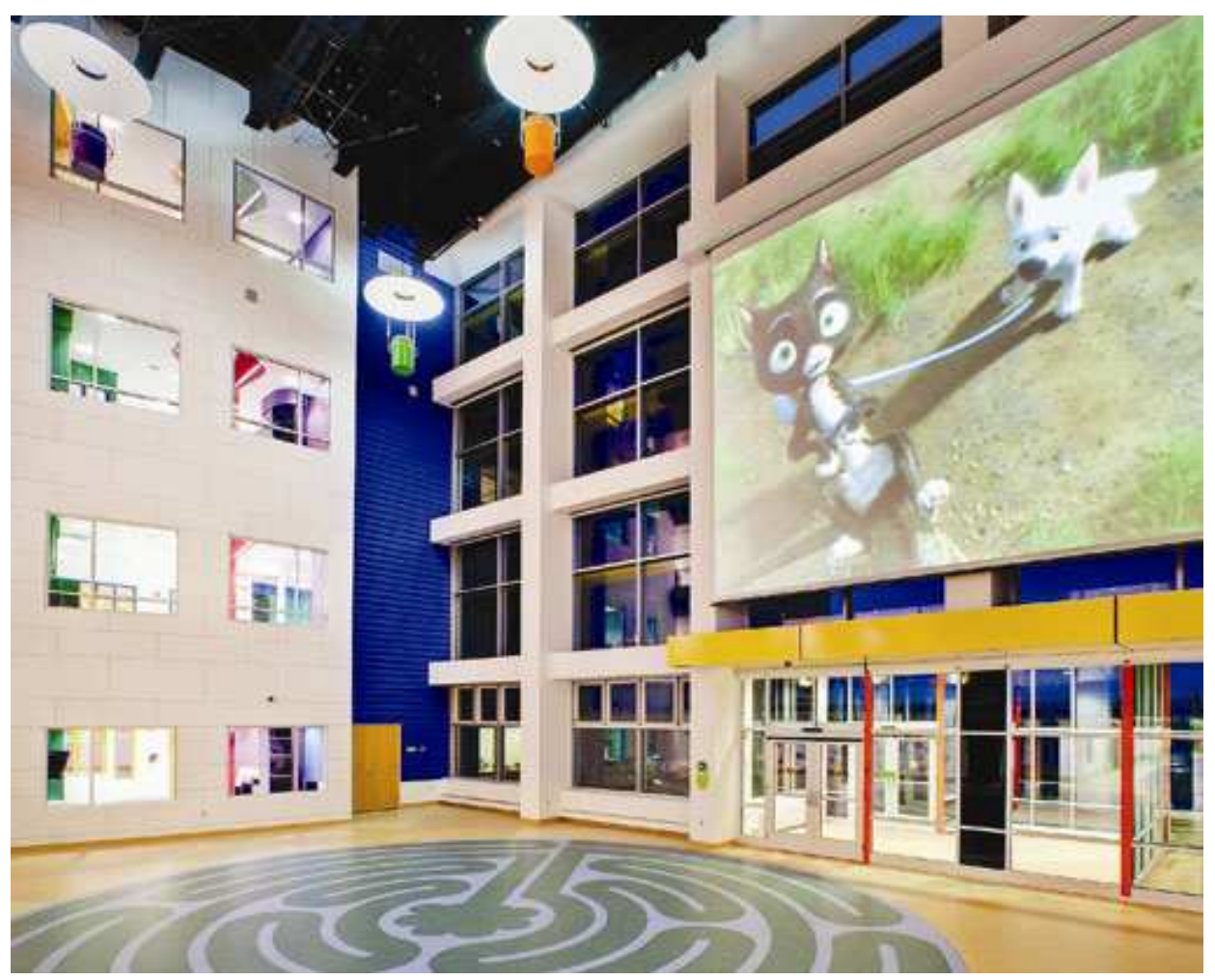

Figura 97 - Átrio principal - Children's Hospital of Pittsburgh.

Elementos gráficos familiares ao publico infantil, representam a 'cidade das crianças'. Composição cromática estruturada em cores complementares e contrastes de brilho. As cores foram escolhidas baseadas em associações e simbologias, como o uso do verde sobre o azul no desenho do labirinto. Fonte: www.astorino.com/portfolio. 
CAPÍTULO 9 CONSIDERAÇÕES FINAIS 


\section{CAPÍTULO 9 CONSIDERAÇÕES FINAIS}

\subsection{CONCLUSÕES}

Ao se iniciar esta pesquisa, imaginava-se, como resultado final, identificar composições cromáticas que pudessem ser descritas em termos técnicos pelos atributos das cores e que representassem um modelo ideal para auxiliar o tratamento terapêutico de pacientes hospitalares e o desenvolvimento de atividades no ambiente hospitalar, proporcionando bem-estar aos usuários daquele ambiente. Mas, do contrário ao imaginado, o resultado obtido com a investigação revelou que o tema possui uma maior amplitude, não sendo possível restringir-se a uma simples formulação ou paleta cromática. Para chegar a esse fato, um longo caminho foi percorrido.

Uma consideração importante a se fazer é que, no decorrer do trabalho, os estudos desenvolvidos, nos Capítulos iniciais, Dois, Três e Cinco, mostraram-se fundamentais para a compreensão e apontamentos da complexidade que envolve as composições cromáticas no ambiente hospitalar. Pois, nos Capítulos Sete e Oito, que tratam, especificamente, dos objetivos desta dissertação, serviu de base para as reflexões, guiando as colocações sobre a temática.

As composições cromáticas para ambientes hospitalares são esquemas complexos e dependentes de outros inúmeros fatores externos. Assim, constata-se que não é possível falar em cores ou esquemas únicos, padronizados e delimitados.

Verificou-se que o sucesso ou fracasso do tratamento terapêutico de cura é fortemente influenciado pelo estado do paciente (físico, social, psicológico, emocional) e pelas relações por ele estabelecidas no ambiente e com o ambiente, por sua vez, verificou-se que esses estados são impactados pelas composições cromáticas do ambiente. Também se constatou que o desempenho das atividades desenvolvidas, no ambiente hospitalar, possui relação estreita com as cores, principalmente, com o conforto visual e a ergonomia proporcionadas por elas. 
Assim, este trabalho propõe que a variedade de estímulos deve prevalecer ao se projetar o ambiente hospitalar, visando obter um design que auxilie positivamente 0 processo de cura do paciente, suporte para as atividades desenvolvidas com qualidades visuais, ergonômicas e ambientais e que proporcione um ambiente transformador das experiências humanas. Nesse ponto, é que cabe às composições cromáticas grande destaque, desempenhando um papel elementar na criação de estímulos. Assim, desejando-se alcançar esses objetivos, concluiu-se, decorrente do estudo realizado nesta dissertação, que as composições cromáticas para os ambientes hospitalares devem ser guiadas pelas seguintes diretrizes:

1. Variedade de matizes, considerando como ideal 0 uso de cores complementares nas composições;

2. Jogo de contrastes nas composições, principalmente, o contraste de matizes e de brilho, esses auxiliam na definição de objetos, distinguindo formas e extremidades;

3. Utilização dos conhecimentos produzidos por outras disciplinas como embasamento para a escolha dos índices de luminosidade e saturação, mas, sobretudo para a escolha dos matizes, pois, como observado, as associações e simbologias relacionam-se a esse atributo da cor especificamente, reservando a ele grande importância;

4. Ter conhecimento holístico da arquitetura, entendendo que a percepção final das composições cromáticas será resultado de outros fatores que englobam o espaço arquitetônico, com suas características e aspectos cognitivos;

5. Conhecer a fundo as características, atributos e aspectos que cercam as cores;

6. Esquematizar a composição cromática sob um sistema de notação cromática, que possibilita uma aplicação mais técnica, eficaz e objetiva;

7. Ao se conceber um projeto, já pensar nas composições cromáticas, obtendose uma unidade compositiva dos elementos da arquitetura;

8. Estruturação das composições sob a relação figura-fundo. 
Finalmente, pretende-se evidenciar que, nesse panorama apresentado até 0 momento, o agente capaz de criar condições para o desenvolvimento dessas relações, focadas em proporcionar bem-estar aos usuários do hospital é o arquiteto; articulador da característica multidisciplinar peculiar à concepção do ambiente hospitalar.

O arquiteto desempenha papel central, cabendo a ele impor seu lugar, mostrando sua importância frente ao espaço construído e as relações nele estabelecidas e tomando para si as atribuições que já lhe pertencem, mas que lhe escapam às mãos, deixando a outrem a função de desenhar as percepções espaciais e composições cromáticas, que invariavelmente influenciam as experiências espaciais dos seres humanos.

No entanto, uma questão levantada é a preparação do arquiteto com relação a essas abordagens. E, por sua vez, salienta o papel que as instituições de ensino exercem, sendo que esses devem prover condições para uma formação plena e ampla, e até mesmo holística do futuro arquiteto, que irá atuar em uma sociedade que quer e espera mais.

Partindo dessas reflexões, como apontamentos, propõe-se a inclusão das temáticas: tecnologia da cor, percepção ambiental e noções de neurociência voltada à arquitetura, na grade curricular dos cursos de arquitetura e urbanismo; mesmo já fazendo parte da grade curricular de muitas instituições esses assuntos, nota-se que não é levado com a seriedade, aprofundamento e amplitude que deveria ser.

Sem dúvida, como constatado ao longo do trabalho, as cores, por meio de composições cromáticas, são elementos de humanização e desenvolvimento da arquitetura hospitalar; não se esgotando o tema, motiva-nos a seguir nos estudos dessas relações, mostrando ainda um desafiador caminho. Muito já se estudou, mas muito ainda está por se fazer, assim, esta dissertação coloca-se como uma contribuição para a discussão e divulgação dos temas aqui levantados.

Espera-se que este trabalho desperte outras pesquisas para os estudos das relações conferidas entre as cores e as reações humanas, ampliando-se as discussões sobre o futuro dos ambientes hospitalares. 
Dessa forma, os resultados obtidos satisfazem parcialmente os anseios iniciais, mas demonstram outros caminhos ainda a serem trilhados, dando continuidade ao processo de aprendizado, pois novas indagações foram geradas a partir das reflexões dos estudos deste trabalho, são elas:

1. Considerando a tendência mundial do serviço hospitalar em diminuir as áreas destinadas às internações ou até mesmo considerando uma descentralização desse serviço do hospital, buscando deixar o paciente em seu habitat natural, objetivando uma melhor recuperação, indagam-se se as pesquisas que vêm cada vez mais crescendo sobre os impactos das cores e outros elementos arquitetônicos, nos seres humanos, não deveriam ser redirecionadas e ampliadas para as áreas comuns do edifício hospitalar, como também àquelas destinadas aos serviços de diagnóstico e tratamento e ao ensino e pesquisa, que vêm crescendo consideravelmente dentro do edifício hospitalar e na própria conceituação da missão e função do hospital. Tal indagação apoia-se em um dos casos levantados, no Capítulo Oito, o Children's Hospital of Pittsburgh. No projeto desse hospital, através do levantamento realizado, vê-se uma visão bem próxima a esta, pois considera-se que todo o edifício compõe uma unidade perceptiva comprometida em promover a cura;

2. Como aplicar os conhecimentos aqui expostos à realidade da arquitetura hospitalar brasileira, de forma mais concisa, efetiva e abrangente;

3. Levantar as questões que envolvem as definições de composições cromáticas para os profissionais brasileiros atuantes, na arquitetura hospitalar, buscando compreender as razões que os levam a escapar de tais atribuições deixando a terceiros,

4. Levantar, no panorama da arquitetura hospitalar brasileira, as visões e abordagens sobre o "Hospital do Futuro".

Com isso, espera-se ter concluído as reflexões e apontamentos resultantes deste trabalho, ressaltando as possibilidades, ainda a se descobrir, proporcionadas pela arquitetura. 
A visão de Leland Kaiser, que diz: "'Na projetação de edifícios, nós projetamos 'conscientemente'. Primeiro, nós damos forma para o edifício, depois ele começa a nos moldar" (KAISER, apud GUZOWSKI, 1999, p. 303, tradução nossa, grifo do autor), nos faz pensar sobre a importância do projeto elaborado em sua amplitude e do papel do arquiteto como idealizador do espaço. De fato, ao se projetar um edifício e imaginar seus ambientes interiores, imagina-se um uso, mas, além disso, desejase que aquele espaço projetado acrescente valor às experiências humanas, elevando-se, assim, as vivências.

Quando ao adentra-se em uma Igreja Gótica, na mais pura expressão do estilo, não sentiu a impotência frente à grandiosidade dos jogos de luzes. Como, ao entrar pelo acesso subterrâneo que nos leva a grande nave da Catedral Metropolitana de Nossa Senhora Aparecida, em Brasília, não se surpreender com o intenso contraste e profunda leveza das formas e com o banho de cor, da imensidão azul dos vitrais.

A característica do espaço arquitetônico de nos elevar é referenciada por Okamoto (1996) que o considera capaz de nos cativar e nos subjugar espiritualmente. Assim, "[...] como a escultura que atua sobre as três dimensões, a arquitetura possibilita que o homem adentre e penetre em seu interior e em sua essência [...] experiência única da arquitetura que marca e deixa impressões no homem (ZEVI, 1996, p. 18)", sendo cada espaço construído, uma expressão única, como Zevi $(1996$, p.18) tão belamente, expõe complementando: "[...] não pode ser representado perfeitamente em nenhuma forma, e que não pode ser conhecido e vivido a não ser pela experiência direta, é o protagonista do fato arquitetônico". 


\section{Bibliografia}

ANTER, Karin. What colour is the red house? Perceived colour of painted facades. Estocolmo: Royal Institute of Technology, 2000.

Forming spaces with colour and light: trends in architectural practice and Swedish colour research. Colour: Design \& Creativity, Bradford, n. 2, 1-10, 2008. Disponível em: <http://www.colour-journal.org/2008/2/2>. Acesso em: 15 dez. 2009.

ARNHEIM, Rudolf. A Dinâmica da Forma Arquitetônica. Lisboa: Presença, 1988.

Arte e Percepção Visual. São Paulo: Pioneira, 1995.

ASTORINO. Disponível em: <http://www.astorino.com/index.php>. Acesso em: 15 mar. 2010.

BACHELARD, Gaston. A poética do espaço. São Paulo: Martins Fontes, 1993.

BAKER, Nick; STEEMERS, Koen. Daylighting design of buildings. London: James \&James, 2002.

BARACH, P.; DICKERMAN, K. Hospital Design promoting patient safety. In: AMERICAN SOCIETY FOR HEALTHCARE ENGINEERING INTERNATIONAL CONFERENCE, 2006, San Diego. Disponível em: <http://hcdesign.coa.gatech.edu/paper/session1/Barach_2_3_2006.pdf>. Acesso em: 10 nov. 2009.

BARROS, Lilian Ried Miller. A Cor no processo criativo: um estudo sobre Bauhaus e a Teoria de Goethe. São Paulo: Senac, 2009.

BATTISTELLA, M. R. A importância das cores em ambientes de trabalho: um estudo de caso. 2003. Dissertação (Mestrado em Engenharia de Produção) Programa de Pós-Graduação em Engenharia de Produção, Universidade Federal de Santa Catarina, Florianópolis, 2003. Disponível em: < http://www.alexandracaracol.com/Ficheiros/A_import\%C3\%A2ncia_das_cores.pdf $>$. Acesso em: 10 jan. 09. 
BAUGHAN-YOUNG, K. Healing power of color as cheap as coat of paint. Managed Care Magazine, Yardley, nov. 2001. Disponível em: <http://www.managedcaremag.com/archives/0111/0111.colors.html>. Acesso em: 05 fev. 09.

BAVARESCO, Nelson. A independência da cor. Mundo Cor, out. 2009. Disponível em: <http://www.mundocor.com.br/cores/independencia_cor.asp out. 2009>. Acesso em: 10 jan. 10.

BECK, C. L. et al. Linguagem sígnica das cores na resignificação (humanização) de ambientes hospitalares. In: CONGRESSO BRASILEIRO DE CIÊNCIAS DA COMUNICAÇÃO, 30, 2007, Santos. Anais eletrônicos... Santos: Intercom, 2007, p. $1-11$.

Disponível em: <http://www.adtevento.com.br/INTERCOM/2007/resumos/R12271.pdf>. Acesso em: 20 ago. 2008.

BERNS, Roy. The principal of color technology. New York: John Wiley\&Sons, 2000.

BILLGER, M. The experience of the painted room: The significance of light and colour combinations. In: INTERIM MEETING OF THE INTERNATIONAL COLOR ASSOCIATION, 2004, Porto Alegre. Proceedings... Porto Alegre: AIC, 2004, p. 219222. Disponível em: < http://www.aic-colour.org/congr_archivos/aic2004proc.pdf>. Acesso em: 10 out. 09.

BILLGER, M.; ANTER; K. F. An architectural understanding of colour research. In: INTERIM MEETING OF THE INTERNATIONAL COLOR ASSOCIATION, 2006, África do Sul. Proceedings... África do Sul: AIC, 2006, p. 70-73. Disponível em: $<$ http://www.aic-colour.org/congr_archivos/aic2006proc.pdf>. Acesso em: 10 out. 09.

$\mathrm{BIRCH}$, J. et al. Sense and Sensibilities: In search of the child-friendly hospital. Built Environment, v. 33, n. 4, p. 405-416, 2007.

BIRREN, Faber. Color \& human response: aspects of light and color bearing on the reactions of living things and the welfare of human beings. New York: Van Nostrand Reinhold, 1978.

BRADY, D.; ENGLISH, M. Color by Default or Intention. Architecture Week, june 2000. Disponível em: <http://www.architectureweek.com/2000/0607/tools_5-2.html>. Acesso em: 02 nov. 08. 
BRASIL, Ministério da Saúde. Secretaria de Assistência à Saúde. Normas para projetos físicos de estabelecimentos assistenciais de saúde. Brasília, DF: 1994.

BRASIL. Ministério da Saúde. Secretaria de Assistência à Saúde. Série: Saúde \& Tecnologia - Textos de Apoio à Programação Física dos Estabelecimentos Assistenciais de Saúde - Arquitetura na Prevenção de Infecção Hospitalar. Brasília, DF: 1995.

BRASIL, Ministério da Saúde. Programa Nacional de Humanização da Assistência Hospitalar (PNHAH): manual de orientação. Brasília, DF: 2001.

BRASIL, Ministério da Saúde. Resolução - RDC n․ . 50, de 21 de fevereiro de 2002. Dispõe sobre o Regulamento Técnico para planejamento, programação, elaboração e avaliação de projetos físicos de estabelecimentos assistenciais de saúde. Brasília, DF: 2002.

BRASIL. Ministério da Saúde. Manual de estrutura física das unidades básicas de saúde. Brasília, DF: 2006.

CAIVANO, José Luis. Sistemas de orden del color. Série Difusion, Buenos Aires, n. 12, $1995 a$.

. Color y semiótica: um camino em dos direcciones. Cruzeiro Semiótico, Porto, n. 22-25, p. 251-265, 1995 b.

Armonías del color. Revista GAC, Buenos Aires, v.7, n. 9, p. 2-21, 2004.

. Research on color in architecture and environmental design: Brief history, $\overline{c u r r e n t}$ developments, and possible future. Color Research and Application, Granada, v. 312, n. 4, p. 350-363, 2006.

CARR, Robert. Health Care Facilities. Whole Building Design Guide, Washington, oct. 2008. Disponível em: <http://www.wbdg.org/design/health_care.php>. Acesso em: 20 nov. 2008.

CARROLL, R. A. Applying design and color to healing. HealthCare Design Magazine, sept. 2004. Disponível em: <http://www.healthcaredesignmagazine.com>. Acesso em: 10 jul. 2008. 
CASTELnOU, A. M. Sentindo o Espaço Arquitetônico. Desenvolvimento e Meio Ambiente, n. 7, p. 145-154, jan./jun. 2003.

CATON, R. Two Lectures of the temples and ritual of Asklepios at Epidaurus and Athens. The British Medical Journal. june 1898, p. 1572-1575. Disponível em: $<$ http://www.ncbi.nlm.nih.gov/pmc/articles/PMC2411783/pdf/brmedj086160004.pdf/?tool=pmcentrez $>$. Acesso em: 15 mar. 10.

Hippocrates and the temple of Cos. The British Medical Journal, mar. 1906, p. 571-574. Disponível em:

<http://www.ncbi.nlm.nih.gov/pmc/articles/PMC2411783/pdf/brmedj08616-

0004.pdf/?tool=pmcentrez>. Acesso em: 15 mar. 10.

CECOR. Disponível em: <www.sistemacecor.com.br>. Acesso em: 10 out. 2009.

CÉSAR, J.C.O. Cor e Percepção Ambiental. In: SEMINÁRIO INTERNACIONAL: PSICOLOGIA E PROJETO DO AMBIENTE CONSTRUÍDO. Anais... Rio de Janeiro: PROARQ, 2000.

. Cor e percepção ambiental: as relações arquetípicas da cor e seu uso em áreas de tratamento de saúde. 2003. Tese (Doutorado em Arquitetura e Urbanismo) - Faculdade de Arquitetura e Urbanismo, Universidade de São Paulo, São Paulo, 2003.

O Uso e a influência das cores na arquitetura de interiores. 1997. Dissertação (Mestrado em Arquitetura e Urbanismo) - Faculdade de Arquitetura e Urbanismo, Universidade de São Paulo, São Paulo, 1997.

CLAY, Rotha Mary. The Medieval Hospitals of England. London: Methuen \& Co., 1909. Disponível em: <http://www.historyfish.net/clay/clay_hospitals.html>. Acesso em: 15 mar. 2010.

COLOR SYSTEM. Disponível em: <http://www.colorsystem.com/>. Acesso em: 10 out. 2009.

CORBIOLI, N. Ambiente hospitalar requer humanização e potencial de atualização constante. Revista Projeto Design, São Paulo, n. 283, p. 94-98, set. 2003. 
COSTA, J. R. Espaço hospitalar: a revolta do corpo e a alma do lugar. Vitruvius, v. 13, n. 079, jun. 2001. Disponível em: <http://www.vitruvius.com.br/arquitextos/arq000/esp079.asp>. Acesso em: 15 ago. 2009.

COSTI, Marilice. A Influência da luz e da cor em corredores e salas de espera hospitalares. Porto Alegre: EdiPUCRS, 2002.

CUNHA, L. C. A Cor no ambiente hospitalar. In: CONGRESSO NACIONAL ABDEH, 1, 2004, Bahia. Anais eletrônicos... Bahia: ABDEH, 2004. Disponível em: $<$ http://bvsms.saude.gov.br/bvs/publicacoes/cor_ambiente_hospitalar.pdf>. Acesso em: 20 ago. 2008.

DA POS, O.; GREEN-ARMYTAGE, P. Colors and basic emotions. In: INTERIM MEETING OF THE INTERNATIONAL COLOR ASSOCIATION, 2006, África do Sul. Proceedings... África do Sul: AIC, 2006, p. 89-92. Disponível em: < http://www.aiccolour.org/congr_archivos/aic2006proc.pdf>. Acesso em: 10 jan. 2010.

DA POS, O.; GREEN-ARMYTAGE, P. Colours and basic emotions. In: INTERIM MEETING OF THE INTERNATIONAL COLOR ASSOCIATION: COLOR, 2004, Porto Alegre. Proceedings... Porto Alegre: AIC, 2004, p. 219-222. Disponível em: $<$ http://www.aic-colour.org/congr_archivos/aic2004proc.pdf>. Acesso em: 10 jan. 2010.

DA POS, O.; GREEN-ARMYTAGE, P. Facial expressions, colours and basic emotions. Colour: Design \& Creativity, Bradford, n. 1, 1-20, 2007. Disponível em: <http://www.colour-journal.org/2007/1/2>. Acesso em: 15 jan. 2010.

DA POS, O.; VALENTINI, S. Colouring the emotions. In: INTERIM MEETING OF THE INTERNATIONAL COLOR ASSOCIATION, 2005, Granada. Proceedings... Granada: AIC, 2005, p. 263-266. Disponível em: <http://www.aiccolour.org/congr_archivos/aic2005proc.pdf>. Acesso em: 15 jan. 2010.

DALKE, H., MATHESON, M. Colour design schemes for long-term healthcare environments. London: Design Research Center, 2007. Disponível em: <http://COLOUR\%20DESIGN\%20SCHEMES\%20FOR\%20LTHCE\%20PART\%20ON E>. Acesso em: 20 mar. 2010.

DALKE, H.; LITTLEFAIR, P. J.; LOE, D. L. Lighting and colour for hospital design: A Report on NHS Estates Funded Research Project. London: TSO, 2004. Disponível em: <www.tso.co.uk/bookshop>. Acesso em: 20 jul. 2009. 
DALLA, T. C. Estudo da qualidade do ambiente hospitalar como contribuição na recuperação de pacientes. 2003. Dissertação (Mestrado em Engenharia Civil) Faculdade de Engenharia Civil, Universidade Federal do Espírito Santo, Vitória, 2003. Disponível em:

<http://www.prppg.ufes.br/ppgec/dissertacao/2003/TerezaDalla.pdf>. Acesso em: 22 jul. 2008.

DAVIDOFF, J. Coloured thinking. The Psychologist, v. 17, n. 10, p. 570-572, oct. 2004. Disponível em: <http://www.gold.ac.uk/media/Davidoff-coloured.pdf>. Acesso em: 10 mar. 2010.

DAVIES, R.W. News, notes and queries: some roman medicine. Journal Medical History, 1, v. 14, p. 101-106, jan. 1970. Disponível em: <http://www.ncbi.nlm.nih.gov/pmc/articles/PMC1034020/>. Acesso em: 20 abr. 2010.

DAY, L. Healing environments and the limits of empirical evidence. American Journal of Critical Care, Aliso Viejo, v. 16 n. 1, p. 86-89, jan. 2007. Disponível em: <www. ajcconline.org >. Acesso em: 20 abr. 2010.

DEL RIO, V. Percepção Ambiental: A experiência Brasileira. São Carlos: UFSCar, 1996.

Projeto do Lugar. Rio de Janeiro: Coleção PROARQ, 2002.

DILANI, A. Psychosocially supportive design: Scandinavian healthcare design. In: Design and Health: the therapeutic benefits of design, 2000. Estocolmo: Svensk Byggtjänstp, 2001. p. 31-38.

DILANI, A. A New paradigm of design and health. Design and Health: International Academy for Design and Health, 15-25, 2003. Disponível em: <http://www.designandhealth.com/uploaded/documents/Publications/Papers/Alan_Dil ani-WCDH2003.pdf>. Acesso em: 20 mar. 2010.

DONDIS, Donis. Sintaxe da Linguagem Visual. São Paulo: Martins Fontes: 1997.

DUFFY, T. The healing use of light and color. Health Care Design Magazine, feb. 2008. Disponível em: <http://www.healthcaredesignmagazine.com>. Acesso em: 10 jul. 2008. 
EDELSTEIN, E. A. The Effects of colour and light. design and health scientific review. World Health Design, p. 57-61, apr. 2008. Disponível em: <http://www.designandhealth.com/uploaded/documents/Publications/Papers/LatrobeFellowship-whd-april08.pdf>. Acesso em: 20 mar. 2010.

ELLIOT, A. J. et al. Color and psychological functioning: the effect of red on performance attainment. Journal of Experimented Psychology: General, v. 136, n. 1, p. 154-168, 2007. Disponível em:

<http://www.psych.rochester.edu/faculty/elliot/documents/2007_ElliotMaierMollerFrie dmanMeinhardt_Color.pdf>. Acesso em: 20 jan. 2010.

FAIRCHILD, Mark. D. Color appearance models. Chichester: Wiley-IS\&T, 2005.

FARINA, Modesto. Psicodinâmica das cores em comunicação. São Paulo: Edgard Blucher, 2006.

FEISNER, Edith A. Color: How to use in art and design. London: Laurence King, 2006.

FERRARA, Lucrécia D’Alessio. Olhar Periférico. São Paulo: Edusp, 1999.

FONSECA, l. et al. Qualidade da luz e sua influência sobre o estado de ânimo do usuário. In: SEMINÁRIO INTERNACIONAL: PSICOLOGIA E PROJETO DO AMBIENTE CONSTRUÍDO. Anais... Rio de Janeiro: Coleção PROARQ, 2000.

FOUCAULT, Michel. Microfísica do Poder. Rio de Janeiro: Graal, 1998.

GESCHEIDER, G. Psychophysics: the fundamentals. New Jersey: Lawrence Erlbaum Associates, 1997.

GOETHE, J. W. Doutrina das cores. São Paulo: Nova Alexandria, 1993.

GRAÇA, L.. Evolução do Sistema Hospitalar: Uma Perspectiva Sociológica (III Parte). Grupo de Disciplinas de Ciências Sociais em Saúde. Escola Nacional de Saúde Pública. Universidade Nova de Lisboa. Lisboa, n. 87, 2000. Disponível em: <http://www.ensp.untl.pt/lgraca/textos87.html>. Acesso em: 27 set. 2009. 
Proto-história do hospital: os asclepions dos gregos e os valetudinaria dos romanos. Grupo de Disciplinas de Ciências Sociais em Saúde. Escola Nacional de Saúde Pública. Universidade Nova de Lisboa. Lisboa, n. 113, 2000. Disponível em: <http://www.ensp.untl.pt/lgraca/textos113.html>. Acesso em: 27 set. 2009.

O Hospital como Expressão Institucional da Caridade Cristã. Grupo de Disciplinas de Ciências Sociais em Saúde. Escola Nacional de Saúde Pública. Universidade Nova de Lisboa. Lisboa, n. 144, 2000. Disponível em: <http://www.ensp.untl.pt/lgraca/textos144.html>. Acesso em: 27 set. 2009.

GRANADO, J. F. E. Atlas de colores. Material de suporte de curso. Disponível em: <http://www.unirioja.es/cu/fede/>. Acesso em: 10 jan. 2010.

GRANDJEAN, E.; KROEMER, K.H.E. Fitting the task to the human: A text-book of occupational ergonomics. Taylor \&Francis: London: 1997.

GREEN-ARMYTAGE, P. Colours: regulation and ownership. Colour: Design \& Creativity, Bradford, n. 4, 1-22, 2009. Disponível em: <http://www.colourjournal.org/2009/4/6/09406article.html>. Acesso em: 15 jan. 2010.

GRUNOW, E. Abaixo a luz asséptica. Revista Projeto Design. Edição 273, set. 2002. Disponível em: <http://www.arcoweb.com.br>. Acesso em: 15 maio 2006.

GUIRAUD, Pierre. A Semiologia. São Paulo: Martins Fontes, 1973.

GUZOWSKI, Mary. Daylighting for sustainable design. New York: McGrawHill,1999.

HALL, Edward T. A Dimensão oculta. Rio de Janeiro: Francisco Alves, 1977.

HÅRLEMAN, M. Colour emotion in full-scale rooms. In: INTERIM MEETING OF THE INTERNATIONAL COLOR ASSOCIATION: COLOR AND PAINTS, 2004, Porto Alegre. Proceedings... Porto Alegre: AIC, 2004. p. 223-226. Disponível em: $<$ http://www.aic-colour.org/congr_archivos/aic2004proc.pdf>. Acesso em: 20 jul. 2009.

HILL, T. R. Using color to create healing environments. Report commissioned by DuPont and LittleFISH Think Tank, mar. 2008. Disponível em: $<$ www2.dupont.com/Surfaces_Commercial/en_US/assets/downloads/pdfs/whitepape r.pdf>. Acesso em: 05 jan. 2010. 
HUBEL, David. Eye, Brain and Vision. 1995. Disponível em: <http://hubel.med.harvard.edu/bcontex.htm >. Acesso em: 20 maio 2008.

ITTEN, Johannes. The Element of Color. New York: Van Nostrand Reinhold, 1970.

KADAR, N. G. Diagnostic colours of emotions. 2007. Thesis (Psychology) Department of Psychology, University of Sydney, Sydney, 2007.

KAISER, P. Physiological response to color: a critical review. Color Research And Application, Granada, n. 9, p. 29-36, 1984.

The joy of visual perception: A web book. 1997. Disponível em: <www. yorku.ca/eye>. Acesso em: 20 maio 2008.

KAPKO, M. Listening and learning: planners for Children's Hospital of Pittsburgh use research to improve healthcare environment. Health Construction and Operations News, v. 7, n. 3, p. 12-14, may 2009. Disponível em:

<www.astorino.com/news/articles/hcomayjune.pdf>. Acesso em: 20 maio 2010.

KARMAN, J B. et al. Arquitetura na prevenção de infecção hospitalar. Brasília: Ministério da Saúde, 1995.

KLICH IIDA, Judy. Interior Design: Not Just Colors Anymore. Health Care Design Magazine, jan. 2005. Disponível em: <http://www.healthcaredesignmagazine.com>. Acesso em: 10 jul. 2008.

KOPACZ, Jeame. Color in three dimensional design. New York: McGraw-Hill, 2003.

LAM, William M.C. Sunlighting as formegivers for architecture. New York: Van Nostrand Reinhold, 1986.

LATORRACA, Giancarlo (org). João Filgueiras Lima Lelé - Aquitetos Brasileiros. Lisboa: Editorial Blau, 2000.

LIGHT relief. Hospital Management Net, mar. 2007. Disponível em: <http://www.hospitalmanagement.net/features/feature1026/>. Acesso em: 10 maio 2007.

LINTON, Harold. Color in architectura. New York: McGraw-Hill, 1999. 
LISBOA, T. C. Breve história dos hospitais da antiguidade à idade contemporânea. Notícias Hospitalares, ano 4, n. 37, jun./jul. 2002. Disponível em: <www.prosaude.org.br/noticias/jun2002/pgs/encarte.htm> Acesso em: 27 out. 2009.

LUKIANTCHUKI, M. A.; CARAM, R. M. Arquitetura hospitalar e o conforto ambiental: evolução histórica e importância na atualidade. In: SEMINÁRIO INTERNACIONAL NUTAU/USP, 7, 2008, São Paulo. Resumo... São Paulo: NUTAU/USP, 2008. Disponível em: < http://www.usp.br/nutau/cd/160.pdf>. Acesso em: 10 out. 2009.

LUKIANTCHUKI, M. A.; SOUZA, G. B. Humanização da arquitetura hospitalar: entre ensaios de definições e materializações híbridas. Vitruvius, ano 10, mar. 2010. Disponível em: <http://www.vitruvius.com.br/revistas/read/arquitextos/10.118/3372>. Acesso em: 20 jun. 2010.

LUNDGREN, L.. A semiotic approach to colour. In: INTERIM MEETING OF THE INTERNATIONAL COLOR ASSOCIATION, 2006, África do Sul. Proceedings... África do Sul: AIC, 2006, p. 97-100. Disponível em: <http://www.aiccolour.org/congr_archivos/aic2006proc.pdf>. Acesso em: 26 jun. 2009.

LYNCH, Kevin. A Imagem da cidade. São Paulo: Martins Fontes, 2001.

MAHNKE, F.; MAHNKE, R. Color and light in man-made environments. New York: Van Nostrand Reinhold, 1996.

MAHNKE, Frank. Color, environment, and human response. New York: Van Nostrand Reinhold, 1996.

MALKIN, Jain. A Visual reference for rvidence-based design. California: Center for Health Design, 2008.

. The design of medical and dental facilities. New York: Van Nostrand Reinhold, 1982.

MALNAR, J. M.; VODVARKA, F. Sensory Design. Minneapolis: University of Minnesota Press, 2004.

MARTINEZ, Alfonso Corona. Ensaio sobre o Projeto. Brasília: UNB, 2000. 
MARTINS, V. P. A Humanização e o ambiente físico hospitalar. In: CONGRESSO NACIONAL DA ABDEH, 1, 2004, Bahia. Anais eletrônicos... Bahia: ABDEH, 2004. Disponível em:

<http://bvsms.saude.gov.br/bvs/publicacoes/humanizacao_ambiente_fisico.pdf>. Acesso em: 20 ago. 2008.

MICHEL, Lou. Light: The shape of space. New York: John Wiley \& Sons, 1995.

MIKELLIDES, B. Emotional and behavioral reaction to colour in the built environment. 1979. Ph. D Thesis - Oxford Polytechnic and Lund Institute of Technology, Oxford, 1979.

MINAH, G. Color as idea: using color as the conceptual basis for architectural and urban design. Colour: Design \& Creativity, Bradford, n. 3, 1-9, 2008. Disponível em: <http://www.colour-journal.org/2008/2/3/>. Acesso em: 15 set. 2008.

MIQUELIN, Lauro Carlos. Anatomia dos edifícios hospitalares. São Paulo: CEDAS, 1992.

MUNSELL. A color notation: an illustrated system defining all colors and their relations. Baltimore: Munsell Color Company, 1941.

NCS. Disponível em: <http://www.ncscolour.com/>. Acesso em: 10 out. 2009.

NELSON, C.; WEST, T.; GOODMAN, C. The Hospital built environment: what role might funders of Health services research play? Agency for Healthcare Research and Quality Publication, Rockville, n. 06-0106, aug. 2005. Disponível em: $<$ http://www.ahrq.gov/qual/hospbuilt/index.html\#Contents>. Acesso em: 20 ago. 2008.

NHSLOTION. Disponível em: <http://www.nhslothian.scot.nhs.uk/default>. Acesso em: 15 mar. 2010.

NIGHTINGALE, Florence. Notes of nursing: what it is, and what it is not. New York: D. Aplleton and Company, 1860.

NIGHTINGALE ARCHITECTS. Disponível em: 15 mar. 2010.<http://www.nightingaleassociates.com/index.html>. Acesso em: 
NUTTON, Vivian. Ancient medicine. London: Routledge, 2004.

OBERASCHER, L.; OBERASCHER, F.; GALLMETZER, M. Colour and emotion: an intercultural approach. In: INTERIM MEETING OF THE INTERNATIONAL COLOR ASSOCIATION, 2005, Granada. Proceedings... Granada: AIC, 2005, p. 213-216. Disponível em: < http://www.aic-colour.org/congr_archivos/aic2005proc.pdf>. Acesso em: 20 nov. 2009.

OKAMOTO, Jun. Percepção ambiental e comportamento. São Paulo: IPSIS, 1996.

OU, L-C. et al. The Effect of culture on colour emotion and preference. In: INTERIM MEETING OF THE INTERNATIONAL COLOR ASSOCIATION: 2005, Granada. Proceedings... Granada: AIC, 2005, p. 259-262. Disponível em: <http://www.aiccolour.org/congr_archivos/aic2005proc.pdf>. Acesso em: 20 nov. 2009.

PALLAMIN, Vera. Considerações sobre a noção de "Gestalt" em Merleau-Ponty. Revista Sinopses, São Paulo, n. 16, p. 17-21, dez.1991.

PEDROSA, Israel. Da cor a cor inexistente. Brasília: UNG, 1989.

PLANETREE. Disponível em: <http://www.planetree.org/>. Acesso em: 05 maio 2009.

POMPEU, C. E. Arquitetura Hospitalar. São Paulo: FUPAM, 2005.

PULS, Maurício. Arquitetura e Filosofia. São Paulo: Annablume, 2006.

RASMUSSEN, Steen. Arquitectura Vivenciada. Barcelona: Labor S. A., 1974.

READ, M. A. Use of color in child care environments: application of color for wayfinding and space definition in Alabama child care environments. Early Childhood Education Journal, v. 30, n.4, 2003. Disponível em: <http://www.springerlink.com/content/v8717t8xq8228p34/>. Acesso em: 20 nov. 2009.

ROSSOTI, Hazel. Colour: why the world isn't grey? Princeton: Princeton University Press, 1985. 
ROUSSEAU, René-Lucen. A Linguagem das Cores. São Paulo: Pensamento, 1995.

RUBIN, H.; PRONOVOST, P.; DIETTE, G. From a process of care to a measure the development and testing of a quality indicator. Internacional Journal for Quality in Health Care, v. 13, n. 6, 489-496, 2001. Disponível em: <http://intqhc. oxfordjournals. org/cgi/content/short/13/6/489?rss=1\&ssource=mfc . Acesso em: 20 nov. 2007.

RUBIN, H.; PRONOVOST, P.; DIETTE, G. The advantages and disadvantages of process-based measures of healthcare quality. Internacional Journal for Quality in Health Care, v. 13, n. 6, 469-474, 2001. Disponível em: <http://intqhc. oxfordjournals.org/cgi/content/short/13/6/469?rss=1\&ssource=mfc>. Acesso em: 20 nov. 2007.

SANTOS, Mauro; BURSZTYN, Ivani (Orgs.). Saúde e Arquitetura: caminhos para a humanização dos ambientes hospitalares. Rio de Janeiro: SENAC, 2004.

SATO et al. An Investigation of Colour Emotions using Two-Colour Combinations. In: INTERIM MEETING OF THE INTERNATIONAL COLOR ASSOCIATION, 2005, Granada. Proceedings... Granada: AIC, 2005, p. 271-274. Disponível em: $<$ http://www.aic-colour.org/congr_archivos/aic2005proc.pdf>. Acesso em: 25 abr. 2009.

SCHMID, Aloísio Leoni. A Idéia de conforto: reflexões sobre o ambiente construído. Curitiba: Pactoambiental, 2005.

SCHOPENHAUER, Arthur. Um Tratado sobre a visão e as cores. São Paulo: Nova Alexandria, 2003.

SILVA, K. P. Hospital, Espaço Arquitetônico e Território. 1999. Tese (Doutorado em Arquitetura) - Faculdade de Arquitetura e Urbanismo, Universidade de São Paulo, São Paulo, 1999.

SILVEIRA, L. M. A reprodução cromática em síntese de imagens: um estudo comparativo à pintura. 1994. Dissertação (Mestrado em Artes) - Instituto de Artes Multimeios, Universidade Estadual de Campinas, Campinas. 1994.

SINGH, S. Impact of color on marketing. Management Decision, v. 44, n. 6, p. 783789, 2006. doi:10.1108/00251740610673332. 
SMITH, D. Colour and space: an investigation of three- dimensionality. Interior Design/ Interior Architecture Educators Associacion IDEA. Australia, p. 103-116, 2004. Disponível em: <http://www.idea-edu.com/Journal/2004/2004-IDEA-Journal>. Acesso em: 15 jul. 2009.

STAHRE, B.; HÅRLEMAN, M.; BILLGER, M. Colour emotions in larger and smaller scale. In: INTERIM MEETING OF THE INTERNATIONAL COLOR ASSOCIATION, 2004, Porto Alegre. Proceedings... Porto Alegre: AIC, 2004, p. 27-30. Disponível em: <http://www.aic-colour.org/congr_archivos/aic2004proc.pdf>. Acesso em: 20 out. 2009.

SWAIN, Adrian. Sense sensitive design and the optimal learning environment. Nightingale Associates, 2010.2 Disponível em: <www.nightngaleassocait.com.2010>. Acesso em: 25 jul. 2010.

SWIRNOFF, Lois. Dimensional Color. New York: Norton\&Company, 2003.

TAKAHASHI, S. Effects of coloured lighting on judgement of emocional expression. Colour: Design \& Creativity, Bradford, n. 4, 1-6, 2006. Disponível em: <http://www.colour-journal.org/2009/4/1>. Acesso em: 10 fev. 2010.

TOFLE, R.B. et al. Color in healthcare environments: a critical review of the research literature. CHER, 2004.

TOLEDO, L. C. Feitos para curar: arquitetura hospitalar e processo projetual no Brasil. 2002. Dissertação (Mestrado em Arquitetura e Urbanismo) - Faculdade de Arquitetura e Urbanismo, Universidade Federal do Rio de Janeiro, Rio de Janeiro, 2002. Disponível em:

<http://mtarquitetura.com.br/conteudo/publicacoes/HOSPITAL_TERAPEUTICO.pdf>. Acesso em: 10 jul. 2008.

Do hospital terapêutico ao hospital tecnológico: encontros e desencontros na arquitetura hospitalar. In: SANTOS, Mauro; BURSZTYN, Ivani (orgs.). Saúde e Arquitetura: caminhos para a humanização dos ambientes hospitalares. Rio de Janeiro: SENAC, 2004, p. 92-105.

Humanização do edifício hospitalar: um tema aberto. PROJETAR 2005. Disponível em:

<http://www.mtarquitetura.com.br/.../HUMANIZACAO_\%20EDIFICIO_HOSPITALAR. pdf>. Acesso em: 05 nov. 2008. 
TUAN, Yi-Fu. Topofilia: um estudo da percepção, atitudes e valores do meio ambiente. São Paulo: Difusão Editorial, 1980.

Espaço e Lugar: A perspectiva da experiência. São Paulo: DIFEL, 1983.

ULRICH, R.S. View through a window may influence recovery from surgery. Science, v. 224, n. 4647, p. 420-421, apr. 1984.

. Wellness by design: psychological supportive patient surroundings. Group Practice Journal, p. 10-19, july./aug. 1991.

. Evidence-based garden design for improving health outcomes. In: CONFERENCE, INVESTIGATING THE RELATIONSHIP BETWEEN HEALTH AND THE LANDSCAPE, 2000, Minnesota. Proceedings... Minnesota: University of Minnesota Landscape Arboretum, 2000, p. 30-58.

. Effects of Healthcare Environmental Design on Medical Outcomes. In: conference, International Academy for Design and Health, 2000b, Canada. Proceedings... Canada: 2000b, p. 49-59. Disponível em: $<w w w . d e s i g n a n d h e a l t h . c o m / . . . / R o g e r-U l r i c h-W C D H 2000 . p d f>$. Acesso em: 10 nov. 2009.

. Health benefits of gardens in hospitals. In: CONFERENCE PLANTS FOR PEOPLE, INTERNATIONAL EXHIBITION, 2002, Florida. Proceedings.... Florida: 2002. Disponível em:

$<$ http://www.greenplantsforgreenbuildings.org/attachments/.../HealthSettingsUlrich.pd f>. Acesso em: 10 nov. 2008.

ULRICH, R.S. et al. The role of the physical environment in the hospital of the 21 st century: A once in a lifetime opportunity. Report ... Center for Health design for the Designing the 21st Century Hosptial Project, 2004. Disponível em: $<w w w . r w j f . o r g / f i l e s / . . . / o t h e r / R o l e o f t h e P h y s i c a l E n v i r o n m e n t . p d f 2004>$. Acesso em: 10 out. 2007.

ULRICH, R.S. et al. A Review of the research literature on evidence-based healthcare design - DCPH 2000. Health Environments Research \& Design, v. 1, n. 3, 2008. Disponível em:

<http://smartech.gatech.edu/bitstream/1853/25676/1/zimring_HERD_2008_researchli treview.pdf>. Acesso em: 10 jan. 2009. 
UNIQUE process creating new Karolinska Solna. Disponível em: <http://en.white.se/start>. Acesso em: 10 jul. 2010.

VEIGA, José Eli. Desenvolvimento Sustentável: O desafio do século XXI. Rio de Janeiro: Garamond, 2008.

Meio Ambiente e Desenvolvimento. São Paulo: SENAC, 2006.

VOLLI, Ugo. Manual de semiótica. São Paulo: Loyola, 2007.

WEITEN, Wayne. Introdução à psicologia: temas e variações. São Paulo: Pioneira Thomson, 2002.

WHITE ARCHITECTS. Disponível em: <http://en.white.se/start >. Acesso em: 15 mar. 2010.

YU et al. Study on physiological responses to color stimulation: focused on user centered design sensibility engineering design of color. In: INTERNATIONAL ASSOCIATION OF SOCIETIES OF DESIGN RESEARCH, 2009, Seul. Proceedings.... Seul: IASDR, 2009, p. 1969-1979. Disponível em: <http://www.iasdr2009.org/ap/navigation/byauthorname.html>. Acesso em: 03 mar. 2010.

ZANETTINI, Siegbert. Arquitetura razão sensibilidade. São Paulo: Edusp, 2002.

ZEVI, Bruno. Saber ver a arquitetura. São Paulo: Martins Fontes, 1996. 